का।

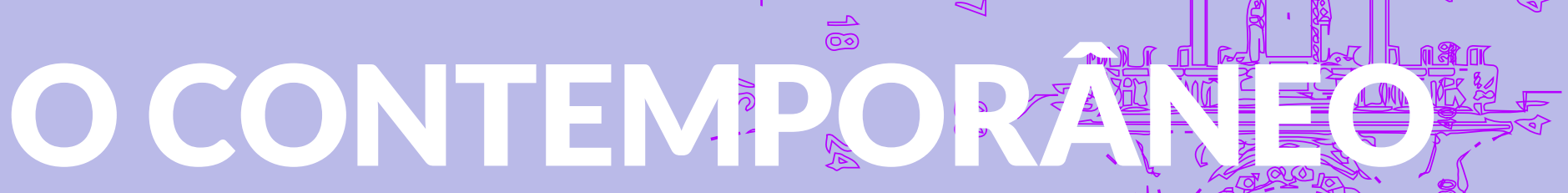

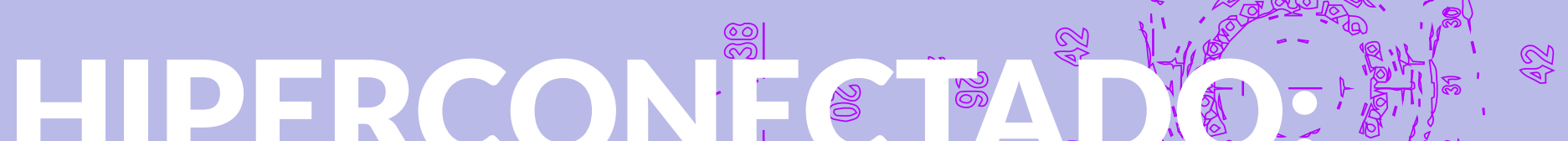
MPERCONES A ADOE.

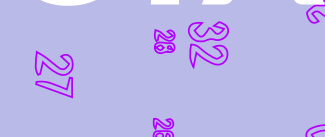

REALIDADEE :
AUMIENTABA: ESEUS

USOS NAS 盟

SOCIAIS E
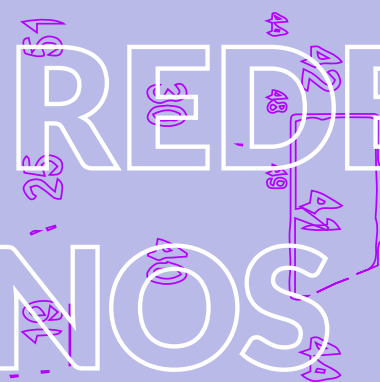

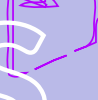
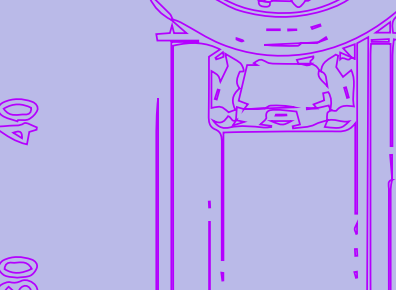
जึ \& । 


$$
\text { UNIVERSIDADE DE SÃO PAULO }
$$

ESCOLA DE COMUNICAÇÕES E ARTES

PROGRAMA DE PÓS-GRADUAÇÃO EM CIÊNCIAS DA COMUNICAÇÃo

Mariane Beline Tavares

O CONTEMPORÂNEO HIPERCONECTADO: REALIDADE AUMENTADA E SEUS USOS NAS REDES SOCIAIS E NOS

VIDEOGAMES

São Paulo 
Mariane Beline Tavares

\title{
O CONTEMPORÂNEO HIPERCONECTADO: REALIDADE AUMENTADA E SEUS USOS NAS REDES SOCIAIS E NOS VIDEOGAMES
}

\author{
Dissertação apresentada ao Programa de Pós- \\ graduação em Ciências da Comunicação da Escola \\ de Comunicações e Artes da Universidade de São \\ Paulo (PPGCOM/ECA/USP) como parte dos \\ requisitos para obtenção do título de mestrado em \\ Ciências da Comunicação. \\ Área de concentração III: Interfaces sociais da \\ comunicação. \\ Linha de Pesquisa: Comunicação e Educação. \\ Orientadora: Professora Dr ${ }^{\mathrm{a}}$ Brasilina Passarelli.
}

São Paulo 
Autorizo a reprodução e divulgação total ou parcial deste trabalho, por qualquer meio convencional ou eletrônico, para fins de estudo e pesquisa, desde que citada a fonte.

Catalogação na Publicação

Serviço de Biblioteca e Documentação

Escola de Comunicações e Artes da Universidade de São Paulo

Dados inseridos pelo(a) autor(a)

Tavares, Mariane Beline

O CONTEMPORÂNEO HIPERCONECTADO: REALIDADE AUMENTADA E

SEUS USOS NAS REDES SOCIAIS E NOS VIDEOGAMES / Mariane

Beline Tavares ; orientadora, Brasilina Passarelli. -- São

Paulo, 2020.

209 p.: il.

Dissertação (Mestrado) - Programa de Pós-Graduação em

Ciências da Comunicação - Escola de Comunicações e Artes /

Universidade de São Paulo.

Bibliografia

Versão original

1. Realidade aumentada 2. Literacias 3. Dispositivos 4.

Percepção Visual 5. Atores humanos e não humanos I.

Passarelli, Brasilina II. Título.

$$
\text { CDD 21.ed. - 302.2 }
$$

Elaborado por Alessandra Vieira Canholi Maldonado - CRB-8/6194 
Liberdade é pouco. O que eu desejo ainda não tem nome.

Clarice Lispector 


\section{Agradecimentos}

Ao longo desses anos de pesquisa, muitas pessoas participaram desse processo, me apoiando e incentivando, ou muitas vezes apenas ouvindo meus fluxos de pensamento e angústias diante da tentativa de abraçar o mundo fazendo essa pesquisa.

Gostaria de começar agradecendo aos meus pais que, com todo seu amor e apoio, propiciaram um ambiente possível para que isso acontecesse, por todos os ensinamentos, todas as idas às livrarias, todas as viagens juntos e por me aguentarem sendo educadora em todas as visitas em museus, mas principalmente agradeço a eles por terem me ensinado o apetite acadêmico e esse permanece me alimentando de forma inesgotável;

Às minhas meninas Sofia, Brigitte e Amelie com seus cheirinhos e latidos;

A Riva e Dani que me acolheram como filha coletiva de um grupo tão maravilhoso;

A Selmara por ser minha irmã de vida e de luta;

A Sandra e a Bella com nossas relações de madrinhagem;

À Universidade de São Paulo, bem como seus servidores, que há mais de dez anos se tornou minha segunda casa e a todas as mulheres pesquisadoras que lutam por condições melhores e maior representatividade;

À minha orientadora, Brasilina Passarelli, por compartilhar seu conhecimento e sabedoria ao longo de todo esse processo, ao administrar minhas falhas e interpretar meus acertos;

À Escola do Futuro, que desde 2018 me acolheu e propiciou um ambiente de discussão muito enriquecedor;

Aos meus professores no decorrer das duas graduações e especialmente ao Luli Radfahrer, por ser meu jardineiro desde os tempos longínquos de graduação e pelas essenciais contribuições no exame de qualificação;

A Mariana e Paula, que em tantos anos de amor e amizade diariamente me ensinam que a vida é muito melhor quando compartilhada; 
A Paulinho, Carina, Juliana, Milena e Mayara que juntos desde o primeiro dia de universidade são meus parceiros nessa vida;

A Luiza, Emerson, Marina S., Eloisa, Marina A., Caio e Cris, que com benquerença e arte iluminaram meu caminho e a Bruna por me acompanhar nesse caminho acadêmico que a cada conversa e aprendizado tornava o percurso bem menos solitário;

Por fim, gostaria de agradecer a todos os escritores e artistas que a partir das palavras e imagens me ensinaram e me atravessaram, alimentando e fortalecendo-me com a potência da Arte. 


\section{RESUMO}

A pesquisa centra-se nos questionamentos a respeito da sociedade contemporânea a partir da intensificação da tecnologia no cotidiano. O foco é voltado à realidade aumentada, com sua potencialidade de interação e embaçamento do/entre mundo real e da virtualidade. Construindo um panorama bibliográfico acerca do contemporâneo hiperconectado, aborda temas como a aldeia global, a teoria ator-rede, o movimento onlife, a quarta revolução tecnológica, a big tech, as literacias de mídia e informação, transhumanismo e o mirrorworld. Além disso, discorre a respeito de uma aceleração do tempo e em como se altera a percepção visual dos indivíduos em uma sociedade estruturada no capitalismo 24/7. Dentre os sistemas tecnológicos compreendidos nessa estrutura, atentaremos a duas: as redes sociais e os videogames. O campo da indústria dos videogames é abordado com dados sobre a área e com uma análise crítica sobre o jogo Pokémon GO, mapeando em como os videogames e as redes sociais têm um papel importante na disseminação e acessibilidade da realidade aumentada a partir dos dispositivos móveis. O interesse nesse enfoque é compreender a percepção visual e em como vivenciam e acessam as literacias, de que forma essas novas semânticas e novas lógicas estabelecem uma reflexão dessa ordem social organizada a partir das interfaces e das superfícies de mediação.

Palavras-chave: Realidade aumentada; Literacias; Visualidade; Percepção; Dispositivos; Atores humanos e não humanos. 


\begin{abstract}
The research focuses on questions about contemporary society, based on the intensification of technology in everyday life. The focus is on augmented reality, with its potential for interaction and blurring of / between real world and virtuality. Constructing a panorama of the hyperconnected contemporary, it addresses topics such as the global village, actor-network theory, the onlife movement, the fourth technological revolution, big tech, media and information literacies, transhumanism and mirrorworld. In addition, it discusses an acceleration of time and how the visual perception of individuals changes in a society structured in capitalism 24/7. Among the technological systems included in this structure, we will look at two: social networks and video games. The video game industry field is approached with data about the area and a critical analysis of the Pokémon GO game, mapping how video games and social networks play an important role in the dissemination and accessibility of augmented reality from mobile devices. The interest in this approach is to understand the visual perception and how they experience and access literacies, how these new semantics and new logics establish a reflection of this organized social order based on the interfaces and surfaces of mediation.
\end{abstract}

Keywords: Augmented reality; Literacies; Visuality; Perception; Devices; Human and non-human actors. 


\section{Lista de Figuras}

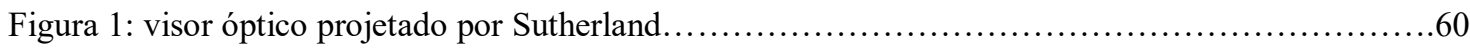

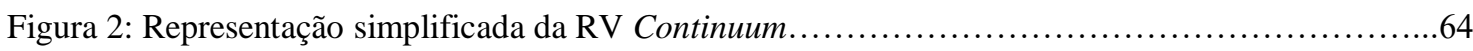

Figura 3: intervenção do coletivo manifestAR no MoMa...........................................77

Figura 4: Frame do registro do trabalho Alter Bahnhof Video Walk(2012)...............................................78

Figura 5: Registro instalação After Eden no catálogo FILE 2018 - O corpo é a mensagem................80

Figura 6: Registro instalação Me, Myself \& I no catálogo FILE 2019 - 20 anos de FILE 20 anos de arte e

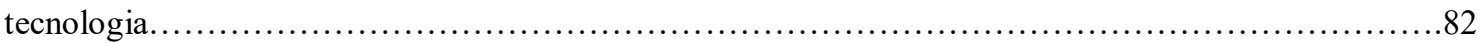

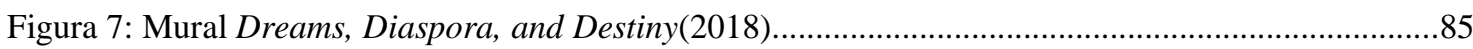

Figura 8: registro de elementos em realidade aumentada derivados do mural......................... 86

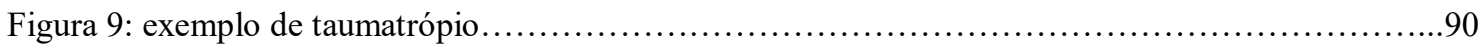

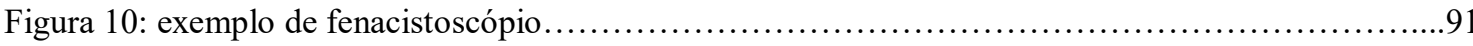

Figura 11: Frame do vídeo sobre o lançamento do programa ARCore Depth API Deep Dive.............95

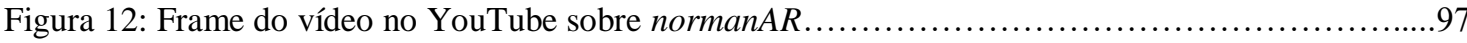

Figura 13: Frame do vídeo no YouTube sobre o DrawalongAR .........................................99

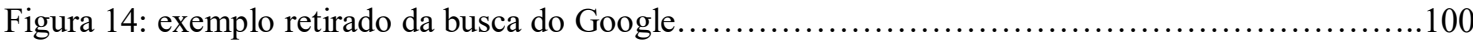

Figura 15: Print Screen retirados do aplicativo Instagram............................................ 104

Figura 16: Sensor Tower - Abril de 2020 em busca sobre "Data That Drives App Growth"..................107

Figura 17: Global Entertainment \& Media Outlook 2018-2022 por PwC................................113

Figura 18: Global Entertainment \& Media Outlook 2018-2022 por PwC.............................114

Figura 19: Global Entertainment \& Media Outlook 2018-2022 por PwC.................................114

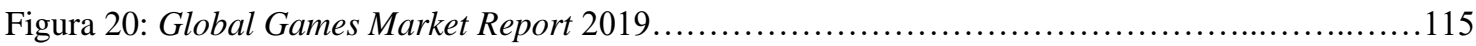

Figura 21: Global Games Market Report 2019........................................................116

Figura 22: Frames do vídeo Buddy Adventures no canal oficial do YouTube lançado em dezembro de

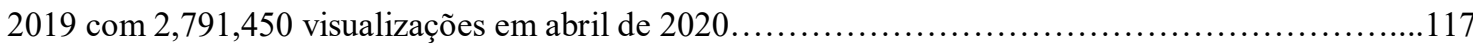

Figura 23: $2^{\circ}$ Censo da Indústria Brasileira de Jogos Digitais (2018).....................................................119

Figura 24: $2^{\circ}$ Censo da Indústria Brasileira de Jogos Digitais (2018).......................................................120

Figura 25: $2^{\circ}$ Censo da Indústria Brasileira de Jogos Digitais (2018).....................................................121

Figura 26: $2^{\circ}$ Censo da Indústria Brasileira de Jogos Digitais (2018)...................................................122

Figura 27: O mundo invisível dos games pela Talk Ink(p.18, 2017)....................................................125

Figura 28: O mundo invisível dos games pela Talk Ink(p.88, 2017) .....................................................126 
Figura 29: O mundo invisível dos games pela Talk Ink(p.27, 2017) 126

Figura 30: Sensor Tower - Abril de 2020 em busca sobre "Data That Drives App Growth".... 129

Figura 31: Sensor Tower - Gasto anual no jogo Pokémon GO.................................130

Figura 32: Print screen do jogo no smartphone.......................................... 134

Figura 33: Canal Oficial Pokémon noYouTube............................................136

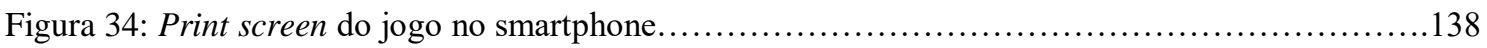

Figura 35: Canal Oficial Pokémon no YouTube vídeo The World of Pokémon GO has Expanded.......139

Figura 36: Canal Oficial Pokémon no YouTube vídeo The World of Pokémon GO has Expanded......139

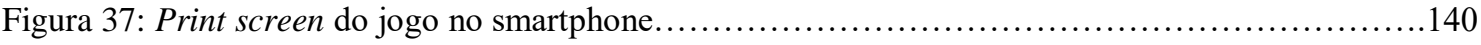

Figura 38: Canal Oficial Pokémon no YouTube Vídeo Advanced Gym Strategy.........................140

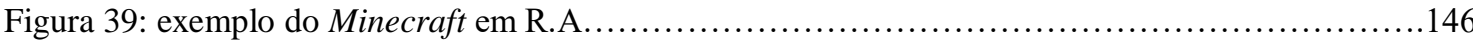

Figura 40: exemplo do Minecraft em R.A. modo combate..................................... 147

Figura 41: Vista da instalação Sistine Chapel em 2019 na Tate Modern............................154

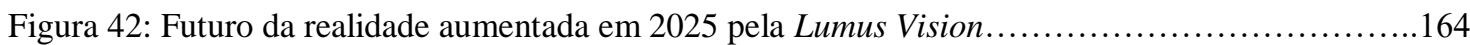

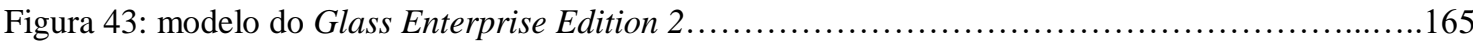

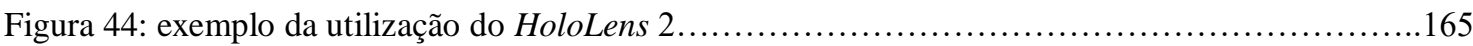

Figura 45: evolução dos protótipos da Mojo Lens.........................................167

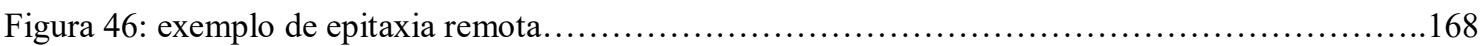

Figura 47: Pesquisa sobre o uso das tecnologias de informação e comunicação - TIC Educação 2019...180

Figura 48: Pesquisa sobre o uso das tecnologias de informação e comunicação nos domicílios brasileiros -

TIC Domicílios 2019. 181

Figura 49: Pesquisa sobre o uso das tecnologias de informação e comunicação nos domicílios brasileiros -

TIC Domicílios 2019. 


\section{Lista de Siglas}

ANT: Actor-Network Theory

Android: sistema operacional do Google

ARCore: kit de desenvolvimento de aplicativos em realidade aumentada

ARL: Association of Research Libraries

GPS: Global Positioning System

iOS: sistema operacional do iPhone

IoT: Internet of Things

MIT: Massachusetts Institute of Technology

MIL: Media and Information Literacy (Literacias de mídia e informação)

PG: Pokémon GO

RA: realidade aumentada

SFI: síndrome da fadiga de informação

TAR: teoria ator rede

TIC: tecnologias da informação e comunicação

VR: realidade virtual 


\section{Sumário}

INTRODUÇÃO 13

CAPÍTULO I - O CONTEMPORÂNEO HIPERCONECTADO E SEUS DESAFIOS 21

1.1) O entendimento do Self na quarta revolução e o movimento Onlife 28

1.2) Uma nova sociabilidade e a aceleração do tempo 33

1.3) A falsa neutralidade e os dispositivos/gadgets 39

1.4) A Teoria Ator-Rede 42

1.5) Literacias de mídia e informação (MIL - Media and Information Literacy)

CAPÍTULO II - BREVE RETROSPECTICA DO DESENVOLVIMENTO DA LINGUAGEM REALIDADE AUMENTADA $\quad 59$

2.1) As definições de Realidade aumentada

2.2) Acesso e usabilidade da realidade aumentada 72

2.3) Realidade aumentada e o movimento Data Art 74

2.4) O constructo da percepção visual 86

$\begin{array}{ll}2.5) \text { Usos nas redes sociais } & 100\end{array}$

$\begin{array}{ll}\text { 2.5.1) Realidade aumentada no Instagram e no TikTok } & 102\end{array}$

CAPÍTULO III - VIDEOGAMES E REALIDADE AUMENTADA 109

3.1) Contexto mundial e local da indústria dos Videogames 109

3.2) Caso Pokémon Go 127

$\begin{array}{ll}\text { 3.2.1) Comentário sobre o jogo Minecraft Earth } & 144\end{array}$

CAPÍTULO IV - PERSPECTIVAS SOBRE O QUE ESTÁ POR VIR: OS FUTUROS $\begin{array}{ll}\text { POSSÍVEIS NO BIG DATA } & 149\end{array}$

4.1) Os usos da realidade aumentada em um futuro próximo - os vestíveis (wearables) 158

4.2) Realidade aumentada no futuro da educação: o aspecto social das literacias $\quad 174$

$\begin{array}{ll}\text { CONSIDERAÇÕES FINAIS } & 184\end{array}$

$\begin{array}{ll}\text { REFERÊNCIAS BIBLIOGRÁFICAS } & 187\end{array}$ 


\section{INTRODUÇÃO}

Essa pesquisa começou com sentimento de perturbação diante do tempo contemporâneo e uma vontade de abarcá-lo de alguma forma. Uma afirmação do filósofo Bruno Latour (2000) exprime o que se entende por ciência neste trabalho: "nossa entrada no mundo da ciência e da tecnologia será pela porta de trás, a da ciência em construção, e não pela entrada mais grandiosa da ciência acabada" (LATOUR, 2000, p.17). O caminho da construção se mostra como o cerne do interesse acadêmico, as decisões a serem tomadas, a incerteza que comumente aparece em uma pesquisa científica e principalmente a curiosidade epistemológica do pesquisador que insiste em trilhar essa trajetória.

Por quase dez anos, o artista Francis Alÿs filmou tornados recorrentes em desertos mexicanos. Sua ação era com uma câmera de mão, perseguir esses tornados e tentar entrar no vórtice, de forma a capturar esses movimentos de tensão e força enquanto o tornado estava em fúria e logo que se dissipava chegava a uma calmaria absoluta. Esse trabalho almeja ser um ponto de reflexão para a contemporaneidade, em que de fato nos encontramos dentro do vórtice do tornado e o quanto isso dificulta a análise com clareza, a dificuldade de enxergar um panorama possível de futuro, mas que é necessário persistir e realizar.

A proposta dessa pesquisa se orienta em direção ao desenvolvimento da sociedade contemporânea a partir da intensificação da tecnologia no cotidiano e da hiperconexão. Dessa forma, depreende-se que com a tecnologia novos questionamentos e aprofundamentos surgiram e, portanto, seja possível analisar as transformações perceptivas advindas da utilização dos dispositivos digitais, especificamente da realidade aumentada.

Assim, entende-se que os dispositivos têm potencial de ampliar os sentidos perceptivos, o contato com o real, que se trata de uma intervenção artificial que potencializa a realidade e da/entre relação com o virtual. Do mesmo modo, essa sobrecarrega tecnológica faz parte de um momento inédito historicamente localizado na contemporaneidade, na qual se encontra uma revolução tecnológica em andamento e a velocidade dos processos ocorre de forma exponencial - o que altera principalmente as formas comunicacionais e as relações entre os sujeitos. 
O problema de pesquisa é se em face dessa ordem tecnológica contemporânea hiperconectada, a realidade aumentada é mais acessível e disseminada a partir dos dispositivos móveis? Levando a outros questionamentos como, por exemplo, se é uma técnica que nos altera em nível de percepção visual?

Nosso objetivo geral é investigar conceitualmente o que se entende por realidade aumentada, de maneira a mapear seus usos atualmente e em tendências futuras e como ela tem sido disseminada.

Como objetivos específicos destacamos:

1- Construir panorama contextual a partir de aprofundamento bibliográfico acerca da sociedade hiperconectada, realizando uma leitura não neutra acerca da tecnologia e revelar como as relações entre os atores são mediadas por um aspecto mercadológico;

2- Investigar conceitualmente o que se entende por realidade aumentada, trazendo definições como aumentada, mista e virtual;

3- Realizar um mapeamento de tendências em um futuro possível que utilizem a realidade aumentada;

4- Avaliar os resultados obtidos via pesquisas sobre a indústria dos videogames e realizar uma análise crítica sobre o jogo Pokémon GO;

5- $\quad$ Evidenciar a visão e a visualidade como elementos essenciais para a realidade aumentada e como essa altera nossa percepção.

A hipótese da pesquisa é que a realidade aumentada está mais disseminada pelos dispositivos móveis e graças aos seus usos nos filtros das redes sociais e nos videogames, gerando um embaçamento da/entre realidade e virtualidade e online e offline, sendo mais facilmente assimiladas pelos chamados nativos digitais (geração Z).

Ao realizar leituras exploratórias na bibliografia, os princípios elencados por Latour (2000) foram absolutamente pertinentes no cerne do desenvolvimento desse estudo, de forma que um desses princípios vale ser destacado aqui,

- Terceiro princípio: nunca somos postos diante da ciência, da tecnologia e da sociedade, mas sim diante de uma gama de associações mais fracas e mais fortes; portanto, entender o que são fatos e máquinas é o mesmo que entender o que as pessoas são. (LATOUR, 2000, p. 423) 
É pelo caminho da gama de associações que se planejou o procedimento metodológico. Ademais, existe a necessidade de reiterar a utilização das regras metodológicas de Latour (2000), destacadas em:

\begin{abstract}
Regra 1: estudamos a ciência em ação, e não a ciência ou a tecnologia pronta; para isso, ou chegamos antes que fatos e máquinas se tenham transformado em caixas-pretas, ou acompanhamos as controvérsias que as reabrem. Regra 2: Para determinar a objetividade ou subjetividade de uma afirmação, a eficiência ou a perfeição de um mecanismo, não devemos procurar por suas qualidades intrínsecas, mas por todas as transformações que ele sofre depois, nas mãos dos outros. (...) Regra 5: com relação àquilo de que é feita a tecnociência, devemos permanecer tão indecisos quanto os vários atores que seguimos; sempre que se constrói um divisor entre interior e exterior, devemos estudar os dois lados simultaneamente e fazer uma lista (não importa se longa e heterogênea) daqueles que realmente trabalham. (...) Regra 7: antes de atribuir qualquer qualidade especial à mente ou ao método das pessoas, examinemos os muitos modos como as inscrições são coligidas, combinadas, interligadas e devolvidas. Só se alguma coisa ficar sem explicação depois do estudo da rede é que devemos começar a falar em fatores cognitivos. (LATOUR, 2000, p. 421-422)
\end{abstract}

Em termos práticos, esse estudo da ciência em ação nessa pesquisa iniciou-se por dedicação em leituras exploratórias, das quais materiais teóricos foram selecionados. Em seguida passou-se pela leitura analítica, visando sumariar e organizar as informações contidas nos livros e nos artigos científicos, mediante a realização de resenhas e fichamentos da bibliografia referencial de forma a avaliar os conteúdos essenciais para o desenvolvimento e resultados da pesquisa, considerando como método primordial da Teoria Ator-rede de Bruno Latour.

No delineamento da estrutura conjuntural do estado da arte optou-se por uma bibliografia pluridisciplinar, considerando que algumas áreas de conhecimento receberão maior destaque, haja vista que estão diretamente ligadas com os objetivos do projeto de pesquisa, das quais se destacam a teoria da comunicação e da educação. Alguns conceitos fundamentais são primordiais no escopo da pesquisa e os autores a serem aprofundados são: Brasilina Passarelli, Marshall McLuhan, Jonathan Crary, Luciano Floridi, Bruno Latour, Paul Milgram, Shirley Turkle, Derrick de Kerckhove, Franco Berardi, Evgeny Mozorov, Jaron Lanier e Fei-Fei Li.

De forma que, a partir de nossa problematização e, na esteira do cumprimento de nossos objetivos, encontramos uma clara vinculação epistemológica aos teóricos referidos, realizou-se a partir do referencial bibliográfico, em especial a perspectiva da 
Teoria Ator-rede de Bruno Latour, a investigação da perspectiva da realidade aumentada.

A fim de evidenciar nossa hipótese, optamos pelo método de Estudo de Caso (YIN, 2015), considerando a necessidade de evidenciar um fenômeno contemporâneo com claras vinculações e interferências na realidade, como nos indica o autor,

\begin{abstract}
(...) um estudo de caso investiga um fenômeno contemporâneo (o "caso") em seu contexto no mundo real, especialmente quando as fronteiras entre o fenômeno e o contexto puderem não estar claramente evidentes. (YIN, 2015, p. 3)
\end{abstract}

Quando delineado o objeto de pesquisa, ficou evidente que a busca textual somente na bibliografia referencial já publicada de forma impressa não seria suficiente, haja vista que muitos estudos são recentes e publicados de forma online. Portanto, a estratégia definida foi de buscar conteúdos acerca da realidade aumentada provenientes de bancos e bases de dados online.

O material buscado foi diverso e numeroso, e mostrou ser primordial a checagem da procedência dos artigos em bases de dados notáveis e conceituados, nacionalmente e internacionalmente. Pontua-se: Biblioteca Digital de Teses e Dissertações (BDTD), Scientific Eletronic Library Online (SciELO), Education Resources Information Center (ERIC), Reserch Gate, Portal de Periódicos da Capes e Portal Brasileiro de informação científica (ARELLANO, 2007, p.16-18).

Um montante considerável de fontes bibliográficas essenciais para a realização deste trabalho estava na língua inglesa, o que propiciou a necessidade de sua tradução.

Nesse sentido, a tarefa de tradução foi realizada com preocupação e constante releitura e avaliação. A intenção era de garantir a justeza às palavras e sentidos orginalmente atribuídos pelos autores em suas obras. Em todos os trechos da bibliografia que foram traduzidos para essa pesquisa, consta a expressão entre parênteses "tradução nossa" juntamente com a identificação do autor, ano e página da citação.

Outro fator de extrema importância para o enriquecimento epistemológico dessa pesquisa foi que ao longo de todo o processo foram realizadas reuniões de pesquisa na Escola do Futuro, em que havia sessões de bancas de pesquisa informais com 
professores convidados, simulando bancas de qualificação e bancas de defesa, propiciando um ambiente de discussão e questionamento das etapas de pesquisa.

Constrói-se uma percepção das condições estabelecidas na contemporaneidade, na maneira como o uso da tecnologia está imbricado no cotidiano e de que forma isso vem transmudando estruturas, relações, instituições e a própria ciência.

Já houve estudos em que os dispositivos tecnológicos não comtemplavam camadas para além do instrumental, com perspectivas que afirmavam até a sua neutralidade ou até indiferença. O que Morozov considera a bolha cor de rosa das primeiras teorias sobre as redes, em que a recepção era muito positiva e pouco crítica.

No entanto, ao aprofundar estudos nas áreas de inteligência artificial, de pesquisa de softwares e filosofia da informação, e aproveitando-se da teoria do ator-rede de Latour, concebe-se uma visão mais integrada dos atores humanos e não humanos, no sentido de perceber que há uma interferência tecnológica significativa na estrutura social e humana.

O paradigma contemporâneo mostra-se como um imbricado complexo de atores, intervenções, mediações e reflexões que demandam do conhecimento científico um constante aprofundamento. Por exemplo, é necessária a reflexão a respeito da conexão/desconexão, em como atualmente a desconexão tornou-se um modelo distante e de que forma a sociedade é moldada pela natureza das mídias. Tendo em conta que assim como sempre o foi, porém a tecnologia eletrônica e digital estimula e encoraja mais envolvimento e sobrecarga de funções e imagética na vida dos indivíduos.

Tal como foi preconizado por Marshall McLuhan, o meio de fato é a mensagem, no sentido de que o meio, ou o processo, a qual ele nomeia de tecnologia eletrônica, "vem mudando a forma e a estrutura dos padrões de interdependência social e todos os aspectos da nossa vida pessoal” (MCLUHAN, 2018, p. 8). De forma que as mídias alteram o ambiente e evocam nos sujeitos relações únicas de percepção sensorial, "a extensão de qualquer dos sentidos altera a maneira como pensamos e agimos - a maneira como percebemos o mundo" (MCLUHAN, 2018, p. 41). Os estudos de McLuhan são relevantes:

(...) não somente pela questão da antecipação de futuro, mas também pela profundidade na qual o autor analisa o componente tecnológico 
em interação com o ser humano e seus possíveis efeitos sociais. (PASSARELLI; GOMES, 2020, p. 256)

A questão da percepção e da visualidade é primordial para o desenvolvimento da pesquisa, haja vista que, além de realizar uma pesquisa bibliográfica de delineamento das teorias e conceitos que abarcam a complexidade das transformações contemporâneas desencadeadas pela tecnologia com teorias e conceituações sobre realidade aumentada, aprofunda-se no estudo especificamente da percepção visual, uma vez que essa nova realidade mista apoia-se majoritariamente sobre a visão.

Delimitando essas possibilidades, realizamos também um aprofundamento acerca da indústria dos videogames e em como o desenvolvimento da realidade aumentada e da realidade virtual acabam sendo pautados por interesses mercadológicos de grandes empresas desenvolvedoras de games.

Assim, o primeiro capítulo contextualiza o contemporâneo hiperconectado, trazendo conceitos como aldeia global, teoria ator-rede, o movimento onlife, a e as literacias de mídia e informação. Além disso, também comenta a respeito da aceleração do tempo e em como se altera a percepção dos indivíduos em uma sociedade estruturada no capitalismo $24 / 7$.

O segundo capítulo trata especificamente da realidade aumentada, o contexto da sua utilização e reflexões sobre sua conceituação, realizando uma breve retrospectiva do acesso e uso da linguagem. Além disso, realiza uma revisão sobre a literatura acerca da visão imagética e da realidade aumentada no campo da arte e sua utilização nos filtros das redes sociais que em muito contribuem para sua aceitação, disseminação e acessibilidade.

Tem-se no terceiro capítulo uma análise específica sobre o campo da indústria de desenvolvimento dos videogames, com dados advindos de pesquisas acerca do mercado, do perfil dos jogadores e dos valores de investimento destinados. Ademais, culmina em uma análise do jogo em realidade aumentada Pokémon GO e um comentário sobre o jogo Minecraft Earth.

O último capítulo reflete sobre as discussões teóricas do big tech, do pósfuturismo e do transhumanismo e realiza um mapeamento de tendências em realidade 
aumentada em um futuro próximo, das quais se destacam as tecnologias vestíveis (wearables). Além disso, realizamos também uma análise acerca da educação diante do digital e como a reinvenção via realidade aumentada pode ser um caminho possível.

Consiste em uma pesquisa bibliográfica e análise de pesquisas já realizadas na área da tecnologia e comunicação em realidade aumentada e no campo da indústria dos videogames.

Assim, um olhar que permeia toda nossa trajetória científica é o que Agamben (2009) identifica como o que é ser um contemporâneo: ser intempestivo, com as quais quer acertar as contas com seu tempo e tomar posição em relação ao presente, situando a sua exigência de atualidade, "a sua contemporaneidade em relação ao presente, numa desconexão e numa dissociação" (AGAMBEN, 2009, p. 58).

O conceito de discronia encaixa deveras nessa explanação, o que significa que não é que o ser contemporâneo seja quem vive em outro tempo, como uma pessoa nostálgica, mas sim quem sabe que não pode fugir dele, odiando-o ou não.

Ser contemporâneo trata-se, portanto, de uma relação bastante singular com o tempo ao qual está inserido, de quem adere a este ao mesmo tempo em que toma um distanciamento: uma relação de dissociação e anacronismo, de estar dentro do vórtice do tornado. Ou seja, quem se adequa absolutamente ao seu próprio tempo, não são contemporâneos, pois não conseguem vê-lo realmente.

Agamben utiliza-se de uma metáfora belíssima que é a de saber ver a obscuridade, de ser capaz de escrever mergulhando a pena nas trevas do presente. É sob esse olhar que se pretende essa reflexão sobre a contemporaneidade. Sendo esse escuro não pejorativo, não uma postura passiva ou inerte, mas de uma potência de atividade e uma habilidade particular que equivale a neutralizar as luzes que provêm da época para descobrir as suas trevas, portanto, “o contemporâneo é aquele que percebe o escuro de seu tempo como algo que lhe concerne e não cessa de interpelá-lo, algo que, mais do que toda luz, dirige-se direta e singularmente a ele" (AGAMBEN, 2009, p.64).

Ser sensível à percepção da luz que procura nos alcançar e não consegue, diante da escuridão, é uma questão de coragem. Parece ser uma leitura apropriada e bastante encantada do papel dos pesquisadores em nossa sociedade, de buscar constantemente essa luz, com um holofote sensível que nos tira da inércia e nos coloca em reflexão. 


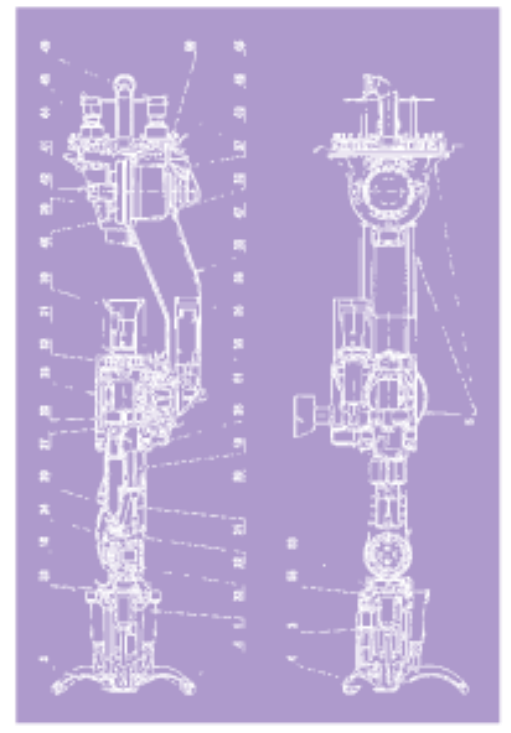

Capítulo I - O contemporâneo conectado e seus desafios 


\section{CAPÍTULO I - O CONTEMPORÂNEO HIPERCONECTADO E SEUS DESAFIOS}

Esse primeiro capítulo é o estado da arte acerca da tecnologia na contemporaneidade, estabelecendo alguns conceitos importantes que serão levados em conta ao longo de toda a pesquisa e que balizam nosso entendimento do que é o contexto da sociedade do contemporâneo hiperconectado.

Trazemos assim conceitos como aldeia global, teoria ator-rede, o movimento onlife, a aceleração do tempo e a percepção dos indivíduos em uma sociedade estruturada no capitalismo 24/7 e por fim as literacias de mídia e informação.

Marshall McLuhan, filósofo canadense, foi um dos pioneiros no estudo da revolução tecnológica e dos estudos culturais. Na década de 1960, conceituou importantes vertentes essenciais de sua pesquisa tais como a Aldeia Global, os meios de comunicação como extensões do homem e o meio e a mensagem. O autor se coloca como “eu não sou um 'crítico da cultura' porque não estou interessado de forma alguma em classificar as formas culturais. Eu sou um metafísico, interessado na vida das formas e suas modalidades surpreendentes" (MCLUHAN, 1995, p.1 - tradução nossa). Poucos autores conseguiram expressar com tamanha sensibilidade como o processo elétrico transforma a realidade humana, por isso a popularidade do autor que ainda é bastante relevante na discussão da centralidade dos meios na sociedade.

Para McLuhan (1964), o homem é fascinado por qualquer tipo de extensão de si mesmo, seja de qualquer material que não seja o dele próprio. Em referência a essa fascinação, o autor remete-se ao mito originário grego de Narciso, jovem dotado de beleza ímpar que se apaixona pelo próprio reflexo, contrapondo com o homem de sua época, que acabou por se tornar um narciso tecnológico, que não se apaixona pelo reflexo, mas apaixona-se pelas extensões.

Para ele, a técnica da eletricidade está em meio a nós e acabamos ficando zonzos, surdos, cegos e mudos no embate com a técnica de Gutenberg, "algo semelhante ocorre com a mídia digital. Somos desprogramados por meio dessa nova mídia, sem que possamos compreender inteiramente essa mudança radical de paradigma" (HAN, 2018, p.10). 
Pensando no smartphone, este funciona como um espelho digital, "abre um espaço narcísico, uma esfera do imaginário na qual eu me tranco. Por meio do smartphone o outro não fala" (HAN, 2018, p.45).

Kerckhove (2009) entende que,

\begin{abstract}
McLuhan viu um padrão puramente psicológico de identificação narcísica com o poder dos nossos brinquedos. Eu os vejo como a prova de que estamos de fato nos tornando cyborgs e de que, à medida que cada tecnologia estende uma das nossas faculdades e transcende as nossas limitações físicas, desejamos adquirir as melhores extensões do nosso corpo. (KERCKHOVE, 2009, p. 21)
\end{abstract}

Nesse sentido, percebe Mcluhan que "contemplar, utilizar ou perceber uma extensão de nós mesmos sob forma tecnológica implica necessariamente em adotá-la" (MCLUHAN, 1964, p. 64). Assim, o uso normal da tecnologia faz com que o homem seja perpetuamente modificado por ela encontrando sempre novas maneiras de modificá-la. Sobre isso, Kerckhove afirma que ao adquirir uma tecnologia "queremos que ele cumpra todas as funções possíveis, não porque alguma vez as vamos usar, mas porque nos sentiríamos limitados e inadequados sem elas" (KERCKHOVE, 2009, p. 21), é o que o autor classifica como tecnofetichismo.

McLuhan considera que existem diferentes formas de extensão, umas de corpo e outras cognitivas, sendo que a fase final seria a simulação tecnológica da consciência, o extremo de quando o processo criativo será coletivo e estendido a toda a sociedade. Sendo que, muito dos nossos sentidos já foram estendidos pelas diversas mídias. Curioso pensar que o autor desenvolveu sua pesquisa da década de 40 até os anos 60, muito antes dos avanços em inteligência artificial atuais.

A sua época foi chamada pelo autor de era da ansiedade, pela razão de que com a explosão elétrica as pessoas foram forçadas ao comprometimento e à participação, já que, "a aspiração de nosso tempo por plenitude, empatia e profundidade de consciência é um complemento natural da tecnologia elétrica" (MCLUHAN, 1995, p.149 - tradução nossa).

Nessa cultura, o meio é a mensagem, significando que as consequências de um meio são as extensões de nós mesmos; é o resultado de uma nova escala introduzida na sociedade das novas tecnologias. Lembrando que "é o meio que configura e controla a 
proporção e a forma das ações e associações humanas" (MCLUHAN, 1964, p. 23) atrelado com seu conteúdo.

Outro conceito importante que McLuhan desenvolveu foi o de Aldeia Global, que seria um importante efeito do processo elétrico, de forma que retribaliza a estrutura da psique humana e da consciência social. Sua percepção a respeito dos sujeitos é a de que "milhões de pessoas sentadas na frente da televisão de tubo, do estilo da CNN, absorvendo o equivalente moderno do conhecimento xamânico da fonte autorizada e analógica para as antigas relações tribais tirânicas das instruções e do controle" (MCLUHAN, 1995, p. 4 - tradução nossa).

\begin{abstract}
Quando o telégrafo fez possível o cruzamento diário do globo transferido para a página impressa, nós já tínhamos um derretimento mental para um homem cósmico - o cidadão global. O mero formato de uma página impressa era mais revolucionário do que as consequências intelectuais e emocionais que qualquer coisa que poderia ser dita em qualquer parte do globo. (MCLUHAN, 1995, p. 304 - tradução nossa)
\end{abstract}

Dessa forma, muitos itens mundiais foram sobrepostos e que isso não seria apenas uma manipulação do espaço, mas que os eventos que trouxeram a aproximação das culturas estavam separados no tempo.

Assim, McLuhan afirma categoricamente que a história foi abolida pelos novos meios, pelas novas literacias. Acerca da questão do self, afirma que a aldeia global estimula as pessoas locais a se retraírem diante dos valores consumistas corporativos, que o que seria uma proteção diante de suas identidades em desbotamento, pois os processos elétricos fazem todos serem ninguéns desesperados por identidades (MCLUHAN, 1995, p. 4 - tradução nossa). De tal forma que seu alerta vem no sentido de indicar que na questão da identidade, todos os processos elétricos sempre produzem violência:

As mudanças profundas aos aparatos percentuais trazidos pelos filmes, televisão, e outras mídias de massa nos retornam às condições similares as das brutalidades tribais que recebem com felicidade na mística da violência que governam as vidas e proliferam nas pessoas. A eletricidade nos leva de volta, converte o mundo em um circuito neo-tribal ressonante. Estamos repetindo os arquétipos da profunda experiência humana, os modelos exemplares da psique e realidade social. (MCLUHAN, 1995, p. 4 - tradução nossa) 
Em uma pontuação histórica, os primeiros efeitos descritos pelo efeito da mídia na transformação do homem foram percebidos no estudo para o livro The Gutemberg Galaxy, publicado em 1962, no qual investiga a revolução da literacia que a prensa de Gutenberg trouxe para o mundo. Assim, linguagem, discurso, gramática, impressão, livros são aspectos da comunicação civilizada e que estariam sob pressão pelas formas primitivas da mídia elétrica, primitivas na forma como reconhecem o sensorial e que apelam para os sentimentos mais do que ao pensamento. McLuhan trabalha na perspectiva da alteração do sensorial como resposta à mídia utilizada: "nossa percepção transformada pode levar a poderosas descobertas" (MCLUHAN, 1995, p. 5 - tradução nossa).

A respeito do que McLuhan chama de era da ansiedade, Abranches (2017) chama de a era do imprevisto, em que a sociedade está em uma conturbada e longa transição, em que a fluidez dos tempos tornou a incerteza a imprecisão maiores.

Abranches afirma que esse intervalo é como que um impasse civilizatório, em que a ideia do fracasso ou do iminente colapso vai ganhando força, por isso a saída pelas distopias e criação de utopias. Considerando essa conjectura, é como se o futuro estivesse opaco. Instituições até então consideradas referências e seguras entram em colapso, como a própria economia, ao qual tem passado por sequência de crises ou mesmo a meteorologia que tem se mostrado incapaz de prever grandes desastres.

Essa fluidez não suporta uma força tangencial ou deformante e, portanto, sofre constante mudança de forma quando submetida a algum tipo de pressão e caracteriza o derretimento dos sólidos que é a contemporaneidade. A diminuição da rigidez faz com que não existam padrões e conceitos eternos, a opção a isso seriam os mil platôs de Félix Guattari e Gilles Deleuze (2010).

Essa teoria se encaixa na mudança de paradigma ao qual está inserida a contemporaneidade, passando de uma ordem positivista, para uma ordem mais móvel, percebendo a realidade de forma rizomática. Portanto, nesse novo modelo de sociedade, o lugar e o espaço são continuamente ressignificados, diante da digitalização, da conectividade em rede, da interação com as interfaces, produzindo um diálogo contínuo e ativo, que faz com que os modelos antigos não sejam mais suficientes para explicar a complexidade dessas interações sociais. 
Entende-se assim, as mudanças epistemológicas no sentido do rizoma, esse que não começa nem conclui: ele se encontra sempre no meio, entre as coisas, inter-ser, intermezzo, como nos indica Deleuze e Guattari,

\begin{abstract}
Resumamos os principais caracteres de um rizoma: diferentemente das árvores ou de suas raízes, o rizoma conecta um ponto qualquer com outro ponto qualquer e cada um de seus traços não remete necessariamente a traços de mesma natureza; ele põe em jogo regimes de signos muito diferentes, inclusive estados de não-signos. O rizoma não se deixa reconduzir nem ao Uno nem ao múltiplo. Ele não é o Uno que se torna dois, nem mesmo que se tornaria diretamente três, quatro ou cinco etc. Ele não é um múltiplo que deriva do Uno, nem ao qual o Uno se acrescentaria $(\mathrm{n}+1)$. Ele não é feito de unidades, mas de dimensões, ou antes de direções movediças. Ele não tem começo nem fim, mas sempre um meio pelo qual ele cresce e transborda. (DELEUZE;GUATTARI, 2010, p. 31)
\end{abstract}

O rizoma é um modelo relacional em que as relações entre os agentes não precisam passar por um centro, ou se submeter a qualquer tipo de hierarquia na distribuição da informação: "podemos ver a rede como uma espécie de esfera de planos múltiplos, uma esfera na qual gira uma série infinita de planos que certamente podem se sobrepor, mas que nunca serão excludentes (BERARDI, 2019, p. 118).

Pensando na estrutura rizomática, um aspecto importante é em como o pensamento científico se baseou na hipótese de Isaac Newton da impenetrabilidade de corpos e, atualizando para o contexto das redes, isso não se aplica, haja vista que: "a rede é o lugar de encontro tendencialmente ilimitado entre agentes de comunicação que não passam o fluxo de suas comunicações por um centro regulador" (BERARDI, 2019, p. 119). Assim, nenhum corpo estendido no espaço pode retirar a possibilidade de expansão de outro corpo.

Sob outra perspectiva, o filósofo Vilém Flusser (1985), faz uma análise certeira das alterações sociais contemporâneas, e propôs que existiu apenas outro momento comparável ao que vive atualmente, que seria um estágio pré-histórico do homem ao passar para uma fase histórica baseada na escrita. E que no estágio contemporâneo seria uma articulação de imagens, multiplicáveis ao infinito:

A função das imagens técnicas é a de emancipar a sociedade da necessidade de pensar conceitualmente. As imagens técnicas devem substituir a consciência histórica por consciência mágica de segunda ordem. Substituir a capacidade conceitual por capacidade imaginativa de segunda ordem. E é neste sentido que as imagens técnicas tendem a eliminar os textos. Com essa finalidade é que foram inventadas. Os textos foram inventados, no segundo milênio A. C., a fim de 
desmagiciarem as imagens (embora seus inventores não se tenham dado conta disto). As fotografias foram inventadas, no século XIX, a fim de remagiciarem os textos (embora seus inventores não se tenham dado conta disto). A invenção das imagens técnicas é comparável, pois, quanto à sua importância histórica, à invenção da escrita. Textos foram inventados no momento de crise das imagens, a fim de ultrapassar o perigo da idolatria. Imagens técnicas foram inventadas no momento de crise dos textos, a fim de ultrapassar o perigo da textolatria. Tal intenção implícita das imagens técnicas precisa ser explicitada. (FLUSSER, 1985, p. 11)

Assim, esquematiza que a cultura ocidental sofreu três grandes divisões: a imaginação marginalizada pela sociedade, o pensamento conceitual hermético e o pensamento conceitual barato. Afirma que uma cultura baseada na cisão não pode sobreviver a menos que seja reunificada e que a tarefa das imagens é de estabelecer o código geral para realizar essa reunificação.

Flusser em sua teoria organiza e classifica três diferenças entre instrumento, máquina e aparelho e as identifica pelo período histórico. Portanto, no período préindustrial, os instrumentos são ferramentas que simulam o corpo; já no período industrial, ocorre uma inversão: não são as máquinas que cercam os homens, mas os homens que as cercam; e por fim, no período pós-industrial o homem emancipa-se do trabalho a partir da automatização, os responsáveis pela ordem são os aparelhos.

Assim como McLuhan, Flusser também entende a prensa de Gutemberg como um marco importante:

\begin{abstract}
A invenção da imprensa e a introdução da escola obrigatória generalizaram a consciência histórica; todos sabiam ler e escrever, passando a viver historicamente, inclusive camadas até então sujeitas à vida mágica: o campesinato proletarizou-se. Tal conscientização se deu graças a textos baratos: livros, jornais, panfletos. (FLUSSER, $1985, \mathrm{p} .12)$
\end{abstract}

Relacionando com as extensões dos homens de McLuhan, Flusser entende os instrumentos como prolongações, já que a intenção dos instrumentos é de arrancar objetos da natureza para aproximá-los do homem. Assim, são prolongações de órgãos do corpo, dentes, dedos, braços, mãos e "alcançam mais longe e fundo a natureza, são mais poderosos e eficientes. Os instrumentos simulam o órgão que prolongam: a enxada, o dente; a flecha, o dedo; o martelo, o punho" (FLUSSER, 1985, p.12). É "característica a essa nova vida a "atrofia das mãos". Os aparatos digitais fazem com 
que as mãos murchem. Eles significam, porém, uma libertação do fardo da matéria" (HAN, 2018, p.61).

Flusser pontua que quando os instrumentos viraram máquinas a relação com o homem se inverteu, já que antes da revolução industrial, os instrumentos cercavam os homens e depois as máquinas é que eram por eles cercadas, "antes, o homem era a constante da relação, e o instrumento era a variável; depois, a máquina passou a ser relativamente constante" (FLUSSER, 1985, p.14).

Sobre a relação do homem com o brinquedo o autor entende que:

Aparelho é brinquedo e não instrumento no sentido tradicional. E o homem que o manipula não é trabalhador, mas jogador: não mais homo faber, mas homo ludens. E tal homem não brinca com seu brinquedo, mas contra ele. Procura esgotar-lhe o programa. Por assim dizer: penetra o aparelho a fim de descobrir-lhe as manhas. De maneira que o "funcionário" não se encontra cercado de instrumentos (como o artesão pré-industrial), nem está submisso à máquina (como o proletário industrial), mas encontra-se no interior do aparelho. Tratase de função nova, na qual o homem não é constante nem variável, mas está indelevelmente amalgamado ao aparelho. Em toda função aparelhística, funcionário e aparelho se confundem. (FLUSSER, 1985, p.15)

E que assim, portanto, não vale mais a pena possuir objetos, isso porque, o poder passou do proprietário para o programador de sistemas, ou seja, quem possui o aparelho não exerce poder, mas quem realiza o programa. Entende que esse processo infinito é como um jogo de poder hierarquicamente estruturado, exemplificando "o fotógrafo exerce poder sobre quem vê suas fotografias, programando os receptores. O aparelho fotográfico exerce poder sobre o fotógrafo. A indústria fotográfica exerce poder sobre o aparelho" (FLUSSER, 1985, p.17).

Há, portanto na estrutura desse jogo simbólico de poder, a diluição e desumanização no que Flusser considera ser a "sociedade informática" e "imperialismo pós-industrial" (FLUSSER, 1985, p.17).

Sua proposição é de que há uma antropologia do digital, em que os sujeitos vivem em mundos alternativos, "o ser humano é segundo Flusser, um 'artista' que projeta mundos alternativos. A diferença entre arte e ciência desaparece. Ambos são projetos" (HAN, 2018, p. 82). Todas as grandes que em algum momento foram fixas se dissolvem, não há mais sujeito, nem tampouco objeto, tudo é um nó de possibilidades. 
O que Flusser entende por sociedade informática, Kerckhove chama de sociedade conectiva e Floridi de era informacional, na qual se tem uma integração tecnológica a três níveis:

1- Interior: hiperconcentração e aceleração do poder computacional

2- Exterior: padronização das redes de telecomunicações internacionais

3- Interatividade biológica homem/máquina na RV (realidade virtual) (KERCKHOVE, 2009, p. 57).

Ou seja, com essa conectividade existe uma nova experiência psicológica dos homens, que gera um novo ser humano capaz de combinar a conectividade com a subjetividade. Para ele "a nossa realidade psicológica não é uma coisa "natural". Depende parcialmente da forma como o nosso ambiente, incluindo as próprias extensões tecnológicas, nos afeta" (KERCKHOVE, 2009, p. 22).

Refletindo sobre essa realidade psicológica, o autor introduz, portanto, dois termos correlacionados: tecnopsicologia e psicotecnologias. Conceituadas respectivamente como estudo da condição psicológica das pessoas que vivem sob a influência da inovação tecnológica e a segunda, para definir qualquer tecnologia que emula, estende ou amplifica o poder das nossas mentes (KERCKHOVE, 2009, p. 23) e Floridi irá explorar mais sobre esse self tecnológico.

\section{1) O entendimento do Self na quarta revolução e o movimento Onlife}

A respeito da conectividade contemporânea, tem-se com o pesquisador da ética da informação Luciano Floridi (2015) uma reflexão profunda sobre a vida na era da hiperconectividade. Para ele, com o advento das tecnologias da informação e comunicação, as chamadas TIC, a sociedade foi afetada radicalmente, de forma que alterou nossa condição humana, nossa percepção e a forma como os sujeitos se relacionam.

O contexto é da quarta revolução tecnológica, e que conceitualmente, é preferível pensar de se trata de uma era informacional ao invés de era computacional. Isso se justifica com o aumento penetrante e cada vez mais importante no ciclo da vida da informação (da sua criação e administração, ao uso e consumo) que afeta profundamente tanto o individual quanto o bem estar coletivo. No sentido mais técnico, 
computadores e computação são apenas uma parte desse fenômeno tão amplo (FLORIDI, 2015, p. 21 - tradução nossa).

Para o autor, "à luz da quarta revolução, nos entendemos como organismos informacionais" (FLORIDI, 2014, p. 98 - tradução nossa) e o valor dos sujeitos está absolutamente interligado ao seu poder de compra realizado pelos cliques.

$\mathrm{O}$ autor refere-se ao que chama de movimento Onlife como uma nova experiência de uma realidade hiperconectada na qual não é mais possível questionar a oposição entre estar online ou offline. Sua pesquisa foi realizada com a contribuição de outros pensadores no que veio a culminar no manifesto Onlife (2015):

Este Manifesto tem como objetivo lançar um debate aberto sobre os
impactos da era sobre espaços públicos, políticas e expectativas
sociais para a formulação de políticas no âmbito da Agenda Digital
para a Europa. Mais amplamente, este Manifesto pretende iniciar a
reflexão sobre a maneira pela qual um mundo hiperconectado pede
para repensar as estruturas referenciais nas quais as políticas são
constrúdas. Este é apenas um começo.... (FLORIDI, 2015, p. 7 -
tradução nossa)

Entende-se que as tecnologias da informação e comunicação (TIC) são mais do que ferramentas e sim forças ambientais que a partir de interações mútuas alteram a concepção de realidade e as interações realizadas com esta. Algumas transformações são elencadas como:

- Embaçamento da distinção entre realidade e virtualidade;

- A forma como estão desfocadas as distinções entre humano, máquina e natureza;

- A inversão da escassez de informações para a abundância de informações;

- E a mudança da primazia das entidades para a primazia das interações.

Assim, um caminho de reflexão é a partir do conceito de reengenharia, repensando a sociedade no que tange a transição digital. Na busca de explorar a relevância das consequências causadas por essas mudanças e inspirar a reflexão sobre o que nos acontece e rever o futuro com maior confiança (FLORIDI, 2015, p. 7 - tradução nossa).

Essa reflexão parte do questionamento de como é ser um humano na era da hiperconectividade, considerando a abundância de informações e como se abriu um caminho de experimentação da liberdade, da igualdade e da alteridade nas esferas 
públicas. Porém, essas demandas não operam de forma pacífica, são mediadas por interações calculadas e controladas.

A qualidade das esferas públicas é bastante prejudicada por esse controle em constante aumento que não é mais somente vindo do chamado big brother - que agora já nem abarca mais a complexidade, sugerimos, portanto o uso do termo Big Tech mas também dos outros sujeitos em rede, aliado ao fenômeno do aumento do chamado cyberbulling.

Mostra-se relevante a reflexão sobre essas novas dinâmicas que estão se concretizando, de buscar o entendimento das vulnerabilidades sistêmicas que surgem da crescente dependência de infraestruturas informacionais.

Floridi (2015) aponta, por exemplo, algumas consequências para o sistema cognitivo decorrentes da abundância de informações, tais como a sobrecarga mental, a amnésia e a distração. O que acarreta uma dependência física e psicológica dos dispositivos, que ocupam o espaço dessas funções que usualmente os sujeitos cumpriam, e que agora são delegadas a esses objetos tecnológicos.

Exemplo cotidiano é a utilização do GPS - Global positioning system - que na tradução em português seria sistema de posicionamento global, um sistema de navegação em mapas que orienta e direciona os caminhos. Seu uso constante pode acarretar problemas de memória e orientação espacial, haja vista que a função essencial do cérebro é terceirizada, deslocada para um dispositivo externo do corpo, uma extensão tecnológica, tal como McLuhan havia preconizado.

Outra questão problematizada pelo autor é que no momento contemporâneo é necessária uma nova reflexão sobre o self, haja vista que essa revolução está iluminando uma nova concepção do que seria o entendimento do self.

Para o autor, esse self relacional começa a se afirmar em termos políticos, que os "eus" são tão livres quanto os sociais, ou seja, a liberdade não ocorre no vácuo, e sim em um espaço de oportunidades e juntamente com isso, uma série de restrições. Ao mesmo tempo da liberdade do eu, deriva-se e aspira-se a relacionamentos e interações com outros eus, artefatos tecnológicos, e o resto da natureza.

Um aspecto importante levantado durante a pesquisa do manifesto Onlife é o paradoxo da relação de avanço das TIC e de como a humanidade parece ter mais dificuldade para identificar fontes específicas de responsabilidade, tal como de previsão de consequências de determinados eventos, especialmente climáticos. A discussão 
acerca disso é o surgimento de uma série de novas responsabilidades que até então não tinham necessidade de serem pautadas.

Dito isso, entende-se em como a reflexão sobre a modernidade mostra-se como necessária para a reflexão da contemporaneidade, haja vista que esse paradigma já não consegue abarcar toda a complexidade de atores e contextos atuais, no sentido de que a modernidade foi toda baseada em uma relação tensa entre humanos e natureza, principalmente caracterizada pela dominação e exploração, com um olhar de superioridade e não somente isso, de um controle racional como se a natureza fosse um reservatório infinito e passivo.

O progresso, o controle e o racionalismo foram entendidos como garantidos e há uma tentativa constante de ainda cercear esse controle. Essa discussão também foi realizada por Latour (1994), quando conclui que, na verdade, o mundo moderno nunca existiu, no sentido que jamais funcionou de acordo com as regras de sua constituição. É muito mais que uma ilusão e muito menos que uma essência. Então o pós-modernismo não seria uma solução, mas sim um sintoma, pois vive sob a constituição moderna, mas não acredita mais nas garantias que ela oferece. Propõe assim, a expressão não-moderno (ou amoderno), que seria todo aquele que leva em conta ao mesmo a constituição dos modernos e os agrupamentos de híbridos que ela nega.

Todo o estudo desenvolvido no manifesto onlife é uma busca de entendimento do caminho para a sociedade das literacias digitais, de desenvolver uma relação crítica e reflexiva com as tecnologias, mas não de procurar um lugar transcendental fora destas mediações. Não se entende como uma possibilidade a total abstração dessa realidade, mas sim que ela está como dada, então que seja pensada, analisada e proporcione reflexões para o futuro. De esforçar-se para entender a tecnologia como imanente, de forma que estão moldando os seres humanos, e que há uma relação de interferência, de tal forma que os humanos também moldam as tecnologias.

É como um movimento inicial, um ponto de partida para moldar esse paradigma ao qual estamos inseridos, e Floridi afirma que é preciso dar mais atenção coletiva à atenção em si, como um atributo humano inerente que condiciona o florescimento das interações humanas e as capacidades de se engajar em ações significativas na experiência da vida.

Há uma menção especialmente a respeito da tecnologia digital e da analógica, na qual mídia é entendida tanto por tecnologias familiares como câmeras digitais, 
armazenamento e de gravação, que são funções incorporadas em smartphones, quanto diversas formas de mídia enquanto distribuição de conteúdo, como meios mais tradicionais, como televisão, rádio e agora os dispositivos mais portáteis.

Floridi comenta o que chama de a "revolução da mobilidade" ou evolução, em sua opinião (FLORIDI, 2013, p. 97 - tradução nossa) é um dos principais locus de pesquisa para a futura evolução da onlife.

Essas tecnologias permanecem analógicas em seus componentes, começando com suas entradas (voz, luz) e saídas (som, imagem) e o lado analógico dessas tecnologias. Assim, destaca o caráter corporificado de seus projetistas, consumidores e usuários. Percebe-se que existe um maior engajamento com a tecnologia se ela ainda mantém alguns elementos analógicos. Porém, chama-se atenção para que com os vários desenvolvimentos de aprimoramento humano e reengenharia realizados, tudo isso pode mudar.

Floridi trabalha com a perspectiva do que nomeia de data ethics (ética dos dados) um nome que abrange mais do que a ética da informação, já que a data science é a última e mais recente fase da revolução da informação (FLORIDI, 2016, p.4 tradução nossa). A respeito da discussão sobre ética, aprofunda no sentido de investigar a fonte de novas dificuldades que são geradas no contexto da quarta revolução industrial.

Assim, a ética dos dados pode ser definida como o estudo que avalia os problemas morais relacionados aos dados, que inclui gravações, curadoria, processos, disseminação, compartilhamento e uso dos dados. Além disso, mostra-se relevante abarcar também os algoritmos e as práticas correspondentes tais como inovação, programação e codificação.

Floridi propõe a expansão do termo, de ética da informação para a ética dos dados, que é "mais provavelmente ser semântica do que conceitual, mas que ilumina a necessidade de concentrar no que está sendo lidado como uma verdade invariável das nossas preocupações" (FLORIDI, 2016, p. 4 - tradução nossa).

Mostra-se como um desafio essa área do conhecimento em que a ética dos dados pode ser mapeada como um espaço conceitual delineado por três eixos de pesquisa: a ética dos dados, a ética dos algoritmos e a ética das práticas (FLORIDI, 2016, p. 5 tradução nossa). A ética dos dados começa como uma macroética, que é como uma 
geometria dos espaços éticos que se aproxima das diversas implicações éticas com uma estrutura consistente, holística e inclusiva.

\section{2) Uma nova sociabilidade e a aceleração do tempo}

Ainda pensando sobre outros aspectos desse self, é considerável refletir sobre a questão da sociabilidade e da vulnerabilidade humana que vem se alterando a partir das relações com os dispositivos tecnológicos. A pesquisadora Sherry Turkle (2011), do MIT - Massachusetts Institute of Technology -, vem realizando ao longo de sua carreira uma profunda análise psicológica e antropológica das relações entre homem e máquina. "The Second Self", seu primeiro livro, data de 1984, coincidência relatada pela autora com a obra de George Orwell, no qual trata sobre o lado subjetivo dos computadores.

Por mais de 30 anos, Turkle realizou uma pesquisa na área de psicologia, e em seu livro "Alone together" (2011) explorou o que chamou de história interna dos dispositivos, questionando cientistas, pesquisadores, donos de computadores e crianças. Objetivou ouvir como os indivíduos falaram e observava como estes se comportavam ao redor das suas máquinas que pensavam.

Para a autora, os computadores possibilitaram trazer a filosofia para todos os dias da vida, em particular, eles transformaram crianças em filósofos ao questionarem o fato dos computadores estarem vivos ou não, se tinham maneiras diferentes de pensar das pessoas e, o que, na era das máquinas inteligentes, era especial sobre ser uma pessoa (TURKLE, 2011, p. x - tradução nossa).

$\mathrm{Na}$ contemporaneidade, os indivíduos estão inseguros diante de seus relacionamentos, ansiosos diante da possibilidade da intimidade. Dessa forma, olham para a tecnologia para estar em relacionamentos e proteger-se desses ao mesmo tempo, esperando menos uns dos outros e mais da própria tecnologia. Um depoimento que relata é de que: "Sinto-me pela terceira vez testemunha de um ponto de virada nas nossas expectativas de tecnologia e nós mesmos. Nós nos curvamos ao inanimado com nova solicitude. Nós tememos os riscos e decepções de relacionamentos com nossos companheiros humanos.” (TURKLE, 2011, p. xii - tradução nossa).

A tecnologia se coloca como sedutora, haja vista que atende às vulnerabilidades humanas, o paradigma de ser solitário e ao mesmo tempo temer a intimidade. Nesse sentido, entende-se que as máquinas, que a autora chama de robôs, inserem-se em todas 
as narrativas humana da fragilidade. Em contraponto, seres humanos demandam excessivamente do psicológico, sendo as demandas das máquinas mais manejáveis. Se os homens estão cansados e com pouca disposição para lidar com a adversidade, as máquinas possuem essa energia ainda.

Turkle aponta que sua pesquisa não se trata da discussão sobre as máquinas e os robôs, mas sim sobre como "somos mudados na medida em que a tecnologia nos oferece substitutos para nos conectar cara a cara. São oferecidos robôs e um mundo inteiro de relações mediadas por máquinas em dispositivos em rede.” (TURKLE, 2011, p. 11 - tradução nossa). E em como a mediação tecnológica redesenhou as barreiras de solidão e intimidade na contemporaneidade.

A potência da amarração à tecnologia, a imbricação na vida cotidiana depara-se com um abalamento diante do mundo desconectado, admitindo que esse já não significa, já não satisfaz, só resta o Onlife. Com a conectividade em tempo completo, altera-se a questão da sobrecarga no cotidiano, tornando-se possível e encorajado. Sendo essa somente de tempo e de espaço, mas também de funções, ser multitarefa é uma condição inerente ao sujeito contemporâneo.

A comunicação interpessoal passou a ser mais uma tarefa entre outras tantas múltiplas. Ao refletir a respeito, Turkle observa que existe uma confusão em se o sujeito está online ou não e assim é fácil ficarem inseguros se estão mais próximos ou mais distantes. Quando percebeu esse senso de desorientação, cunhou o termo alone together, ou seja, sozinho coletivamente. Além do que, juntamente com a constante conexão, criou-se um novo modelo de pânico ao deparar-se com a desconexão.

Estejam esses dispositivos em uso ou não, sem eles, existe o sentimento de deriva causado pela desconexão. Essa desorientação interfere em áreas práticas da vida social e podem tornar-se perigosas, tal como a insistência na utilização dos dispositivos enquanto se dirigem carros, por exemplo.

A utilização da tecnologia no cotidiano transloucou-se, haja vista que considerando quinze anos atrás, por volta da década de 2000, existia como que uma espécie de etiqueta diante do uso dos dispositivos. Poderia ser intrusivo, por vezes ilegal, a utilização de um aparelho celular. Em contraponto com a década de 2010, houve uma adaptação no sentido de acostumar-se a sua utilização em todos os espaços, a vida na bolha da mídia tornou-se natural: 
Então, o fim de certa etiqueta pública: na rua, falamos nos microfones invisíveis em nossos telefones celulares e parecem estarmos falando com nós mesmos. Compartilhamos intimidades com o ar como se não nos preocupássemos sobre quem pode nos ouvir ou os detalhes de nosso ambiente físico. Certa vez, descrevi o computador como um segundo eu, um espelho da mente. Agora a metáfora não é mais o suficiente. Nossos novos dispositivos oferecem espaço para surgimento de um novo estado do self em si, dividido entre a tela e o real, ligado à existência através da tecnologia. (TURKLE, 2011, p. 16 - tradução nossa)

Esse novo self ainda está por definir-se e condições até então desconhecidas estão tornando-se corriqueiras, como por exemplo, com os nativos digitais - termo utilizado para definir uma geração de crianças e adolescentes que são nascidos e cresce com as tecnologias digitais presentes em sua vivência - que relataram em entrevistas em como dormem com os aparelhos celulares e mesmo quando não estão com eles sentem os aparelhos vibrando.

Quase como se "a tecnologia tornou-se como um membro fantasma, é uma parte muito importante deles. Esses jovens estão entre os primeiros a crescer com uma expectativa de conexão contínua: sempre ligado e sempre neles" (TURKLE, 2011, p. 17 - tradução nossa). Diz isso para afirmar que conexão não é sinônimo de comunicação, não necessariamente essa geração nativa digital está se relacionando por meio das telas, estão desenvolvendo novos modelos de relações, por vezes, confusos diante da companhia e companheirismo.

A opressão causada pelo volume e velocidade da vida contemporânea resulta em uma fuga para a tecnologia, em uma maneira de encontrar mais tempo. Porém, o efeito não é o esperado, acaba por ocupar mais ainda e o movimento do recuo cada vez mais estridente. Passa-se a enxergar a vida online como a própria vida, no qual "do que você é feito de - silicone, metal, carne - empalidece em comparação com como você se comporta" (TURKLE, 2011, p. 69 - tradução nossa). Além disso, é nesse momento, que está voltado para a solidão que novas formas de intimidade surgem, entre atores humanos e outros humanos e entre atores não humanos.

Em outro momento, Turkle (2001) afirma novamente sobre a vulnerabilidade do ser humano para a utilização das telas nos modelos que estão estabelecidos, isso porque, as pessoas podem se perder em mundos virtuais, "alguns estão tentados a achar que a vida no ciberespaço é insignificante, um escape ou uma diversão sem significado. Não o é. Nossas experiências são sérias. Nós as menosprezamos ao nosso próprio risco" (TURKLE, 2001, p. 249 - tradução nossa). 
E isso converge com o que Han (2018) propõe, que é a mídia digital como uma mídia de afetos em que "a comunicação digital, em contrapartida, torna uma descarga de afetos instantânea possível. Já por conta de sua temporalidade ela transforma mais afetos do que a comunicação analógica" (HAN, 2018, p. 15). Não a multidão, mas sim a solidão caracteriza a constituição social atual, com os indivíduos singularizados, no que o autor chama de enxame digital:

\begin{abstract}
O homo digitalis ("homem digital") é tudo, menos um "ninguém". Ele preserva a sua identidade privada, mesmo quando ele se comporta como parte do enxame. Ele se externa, de fato, de maneira anônima, mas via de regra ele tem um perfil e trabalha ininterruptamente em sua otimização. Em vez de ser "ninguém", ele é um alguém penetrante, que se expõe e que compete por atenção. (HAN, 2018, p. 28)
\end{abstract}

É como se o habitante digital da rede não se reunisse propriamente, sendo antes de tudo hikikomori, isolados para si, singularizados, que apenas se sentam diante da tela (HAN, 2018, p. 29).

Hikikomori é aquele que vive por muito tempo em condições de permanente reclusão no espaço superconectado do próprio quarto. Não sai para encontrar as pessoas, não são para atravessar a cidade e para ir trabalhar; os pais, com os quais em geral não tem nenhum tipo de relação, lhe trazem a comida. (BERARDI, 2019, p. 145)

Nesse sentido, podemos criar um paralelo com a teoria das mídias quentes e frias de McLuhan, já que as mídias eletrônicas como o rádio geralmente reuniam pessoas e as mídias digitais, de acordo com Han e Turkle, as singularizam.

Porém, existe uma ponderação a respeito desse isolamento social, delegado aos smartphones, mensagens de texto e jogos online que atraem toda atenção dos sujeitos/usuários e especialmente dos jovens. As máquinas foram apresentadas como facilitadores do contato humano e que a rede retirou, "a tecnologia nos corrompeu; robôs irão curar nossas feridas" (TURKLE, 2011 p. 147 - tradução nossa). Os robôs são a proposição de uma espécie de cura da imersão bastante profunda na conectividade digital, e assim, seria uma esperança de volta a direção do real físico.

$\mathrm{Na}$ mesma linha de questionamento, localizando no contexto onde está esse homo digitalis, Crary (2016) propõe o termo capitalismo 24/7, em que qualquer forma de sociabilidade que ultrapasse o interesse individual está condenada ao desaparecimento, isso porque, as relações interpessoais que deveriam ser a base do 
espaço público tornaram-se irrelevantes diante do que ele chama de isolamento digital fantasmagórico causado pelos dispositivos (CRARY, 2016, p. 99).

O que Crary conceitua como o tempo $24 / 7$ se trata de um tempo de indiferença, ao qual a fragilidade da vida humana é cada vez mais inadequada e em como o sono não é mais necessário nem inevitável. Afirma que é um tempo alinhado principalmente com as coisas inanimadas, inertes ou atemporais (CRARY, 2016, p. 196) que podemos entender como as horas passadas nas telas dos smartphones ou jogando videogames.

Sua análise conjuntural abarca muitos fatores e é predominantemente negativa, tal como no momento em que afirma que o imperativo 24/7 é “inseparável da catástrofe ambiental, em sua exigência de gasto permanente e desperdício sem fim, e na interrupção fatal dos ciclos e estações dos quais depende a integridade ecológica do planeta” (CRARY, 2016, p. 19).

Entende o regime 24/7 como um mundo desencantado, muito mais raso do que o dos passados e por isso sem espectros. Afirma a homogeneidade do presente como fraudulenta, que se pretende estender a tudo e antecipar a todo mistério ou o que é desconhecido, "um mundo $24 / 7$ produz uma equivalência aparente entre o que está imediatamente disponível, acessível ou utilizável, e o que de fato existe" (CRARY, 2016, p. 29).

Esse tempo seria sem tempo, sem demarcação material ou identificável, sem sequência nem recorrência, "o tempo do ócio é um outro tempo. O imperativo neoliberal do desempenho transforma o tempo em tempo de trabalho. Ele totaliza o tempo de trabalho. A pausa é apenas uma fase do tempo de trabalho" (HAN, 2018, p.64).

Jackson (2001) dialoga nesse sentido sobre o tempo, que quando digital é fragmentado, no qual pensamentos e eventos comumente colidem de uma forma surreal. Isso seria uma das maiores contradições que os corpos analógicos experienciariam na medida em que as mentes se tornam mais digitais e começam a viver, trabalhar e se entreter no ciberespaço (JACKSON, 2001, p, 349 - tradução nossa).

Para Crary, a vida comum transformou-se em objeto da técnica, acerca especificamente do uso ininterrupto das tecnologias, afirma que o capitalismo 24/7 é uma apreensão contínua ou sequencial da atenção, uma composição do tempo em camadas e que assim, múltiplas operações ou atrações podem ser atendidas quase simultaneamente, independentes do que está se fazendo. 
Critica os aparelhos inteligentes, "os assim chamados aparelhos 'smart' recebem esse nome não tanto pelas vantagens que podem oferecer aos indivíduos, mas por sua capacidade de integrar o usuário a rotinas $24 / 7$ de forma mais completa" (CRARY, 2016, p. 93), ou seja, seriam mais um dispositivo de controle do indivíduo.

Todas as camadas, no sentido de que as divisões temporais entre lazer, trabalho, sono e descanso se dissolvem, se insinua "incessantemente em todos os aspectos da vida social e pessoal. Já não existem, por exemplo, circunstâncias que não podem ser gravadas ou arquivadas em imagens ou informações digitais" (CRARY, 2016, p. 40).

A respeito das relações sociais, Crary caminha proximamente dos estudos de Turkle, haja vista que para o autor, o impacto dos dispositivos e aparelhos nas formas de sociabilidade de pequena escala, tais como nas refeições, conversas ou ambientes de sala de aula, tornaram-se comuns à interferência dos dispositivos, porém isso não torna o dano menor, é bastante considerável. Entende que a antiga ideia de experiência compartilhada fisicamente está se atrofiando e juntamente com isso, o que seriam as gratificações ou/e recompensas prometidas pelas opções tecnológicas mais recentes jamais serão alcançadas.

O ilusório se mostra bastante forte em sua explanação, em como as constantes declarações onipresentes de compatibilidade e harmonia entre o tempo humano e as temporalidades dos sistemas em rede, seja dos aplicativos, dos robôs, dos celulares smart, são, com efeito, disjunções, fraturas e um desequilíbrio contínuo que compõe a experiência real e desigual dessas relações. É isso que se depreende de sua afirmação, que,

\footnotetext{
A realidade bastante diversa do nosso tempo se caracteriza pela manutenção calculada de um permanente estado de transição. Diante de exigências tecnológicas em transformação permanente estado de transição. Diante de exigências tecnológicas em transformação permanente, jamais chegará um momento em que nós finalmente as "alcançaremos", seja enquanto sociedade ou enquanto indivíduos. Dada a velocidade com que surgem novos produtos e se reconfiguram completamente os sistemas, será de alheamento e derrota a relação perceptiva e cognitiva da maioria das pessoas com as tecnologias da informação e comunicação. (CRARY, 2016, p. 46)
}

O autor abarca a discussão sobre a tecnologia e seu uso incessante e a forma como o ritmo das alterações e do aprimoramento - sob o uso de aspas - entendido como a reconfiguração de sistemas, modelos e plataformas, desempenham um papel decisivo na reinvenção do sujeito e na intensificação do controle sob este. 
Isto é, sobre como existe uma grande diversidade de formatos entre os dispositivos, em como tecnologias com a linguagem de realidade aumentada ou interfaces translucidas ocuparão todo o campo de visão do usuário, ou mesmo os desenvolvimentos da chamada informática gestual que descarta o uso dos cliques e os comandos são realizados diretamente por algum gesto (CRARY, 2016, p. 48).

\section{3) A falsa neutralidade e os dispositivos/gadgets}

Parece necessária uma menção especificamente sobre a discussão dos dispositivos e trazemos a perspectiva do filósofo Giorgio Agamben (2009) em que refuta a perspectiva da neutralidade dos instrumentos tecnológicos, pois não haveria um só instante na vida dos indivíduos que não estaria modelado, contaminado ou mesmo controlado pelos dispositivos.

Em diálogo com essa perspectiva, Crary afirma que "longe de ser um meio para um conjunto maior de fins, o dispositivo é um fim em si mesmo; sua função é proporcionar ao usuário uma realização ainda mais eficiente de suas próprias tarefas e funções de rotina" (CRARY, 2016, p. 53).

Desta forma, Agamben traça uma genealogia do termo, que seria um conjunto de estratégias de relações de forças que condicionam certos tipos de saber e que por consequência também são condicionados por ele:

\footnotetext{
Resumamos brevemente os três pontos:

1- Conjunto heterogêneo, linguístico e não linguístico que inclui qualquer coisa no mesmo título: discursos, instituições, edifícios, leis, medidas de policia, proposições filosóficas, etc. o dispositivo em si mesmo é a rede que se estabelece entre esses elementos.

2- $\quad$ O dispositivo tem sempre uma função estratégica concreta e se inscreve sempre numa relação de poder.

3- $\quad$ Resulta do cruzamento de relações de poder e de relações de saber. (AGAMBEN, 2009, p.29)
}

O que é relevante em sua explanação é a constatação de que não existe vida não contaminada pelos dispositivos, no sentido de que eles não são acidentes que os homens caíram por acaso, "mas tem sua raiz no processo de "hominização" que tornou os "humanos" os animais que classificamos sob a rubrica homo sapiens" (AGAMBEN, 2009, p.43), que aqui vamos atualizar para o homo digitalis, cunhado por Han. 
Assim, para o autor:

Sujeitos e viventes costumam sobrepor-se mas não completamente, pode um mesmo indivíduo, ser o lugar de múltiplos processos de subjetivação: o sujeito dos celulares, da internet, o não global, etc. Ao ilimitado crescimento dos dispositivos no nosso tempo corresponde uma igualdade disseminada proliferação de processos de subjetivação. (AGAMBEN, 2009, p.43)

Considerando o que define esses dispositivos no que Agamben chama de a atual fase do capitalismo, é que estes não agem mais tanto na produção de um sujeito, mas principalmente por meio de um processo que ele nomeia de dessubjetivação. No sentido de que "na não-verdade do sujeito não há mais de modo algum a sua verdade" (AGAMBEN, 2009, p.47).

O foco dessa discussão são as mediações dos dispositivos, porém, como esses são absolutamente intricados com a humanidade e esse processo de dessubjetivação do self acaba por criar uma análise maior, das relações entre vários atores humanos e não humanos.

Sobre esse processo, Lanier (2010) questiona a liberdade do sujeito em relação aos dispositivos, ou seja, as máquinas têm mais liberdade que as pessoas, o que também critica no uso das redes sociais, em que não há livre arbítrio:

A World Wide Web foi varrida por uma onda de designs insignificantes algumas vezes chamados de web 2.0. Essa ideologia promove a liberdade radical na superfície da web, mas essa liberdade, ironicamente, aplica-se mais a máquinas do que a pessoas. Mesmo assim, algumas vezes isso é chamado de "cultura aberta". (LANIER, 2010, p. 20)

Lanier utiliza a nomenclatura gadgets e indica que pequenas mudanças nos detalhes do design digital podem alterar de modo profundo e imprevisto as experiências dos seres humanos que o estão utilizando, "a menor mudança em um detalhe aparentemente tão trivial quanto a facilidade de utilização de um botão algumas vezes pode alterar por completo os padrões de comportamento" (LANIER, 2010, p. 20).

Pensando sobre o smartphone como um dispositivo amplamente disseminado como se percebe abaixo: 
É um aparato digital que trabalha com um modo de input-output pobre em complexidade. Ele abafa toda forma de negatividade. Desse modo se desaprende a pensar de um modo complexo. Ele também faz com que definhem formas de comportamento que demandam uma amplitude temporal ou uma visibilidade ampla. Ele demanda o curto prazo e oculta o longo e o lento. (HAN, 2018, p.45)

Desse modo, a questão da profanação dos dispositivos é urgente, cada vez mais os dispositivos se difundem e disseminam seu poder em muitos âmbitos da vida humana, de forma que:

Aquele que se deixa capturar no dispositivo "telefone celular" qualquer que seja a intensidade do desejo que o impulsionou, não adquire, por isso, uma nova subjetividade, mas somente um número pelo qual poder ser controlado; o espectador que passa a vida na televisão recebe em troca da sua dessubjetivação apenas uma máscara frustrante do zappeur ou a inclusão no cálculo de um índice de audiência. (AGAMBEN, 2009, p.48)

Agamben pondera sobre o uso da tecnologia e do discurso ao qual chama de fútil dos que afirmam que o problema dos dispositivos se reduz aquele de seu uso correto e que assim "parecem ignorar que, se todo dispositivo corresponde um determinado processo de subjetivação (nesse caso de dessubjetivação) é totalmente impossível que o sujeito do dispositivo o use de modo correto" (AGAMBEN, 2009, p.48).

Especificamente sobre a realidade aumentada como dispositivo, temos que é um produtor de narrativas:

\footnotetext{
Dispositivo aqui tem o sentido de artefato, mas também de narrativa, de discurso, de mensagem, de proposições, se aproximando do conceito foucaultiano (Foucault, 1966). A RA é um dispositivo produtor de eventos que são narrados pelo caminhar do transeunte no espaço urbano. Ela produz eventos sobre o mundo visível que é contado pelo andar do usuário, produzindo uma narrativa que diminui a complexidade do real. Toda informação faz isso já que ela "dá forma" a algo disforme ou caótico. (LEMOS, 2013, p. 13)
}

Caminhando para a epistemologia mais híbrida, temos com Latour a antropologia simétrica e a teoria ator-rede que considera equanimemente atores humanos e não humanos. 


\section{4) A Teoria Ator-Rede}

Antes de chegar à conceituação da teoria Ator-Rede (TAR), é importante dar um passo anterior e buscar o caminho até essa antropologia, que seria a reflexão sobre a modernidade, no caso a sua falência e ilusão como modelo.

Latour (1994) entende que ser moderno é duas vezes assimétrico: assinala uma ruptura na passagem regular do tempo e aprofunda um combate no qual há vencedores e vencidos. De forma que designa dois conjuntos de práticas diferentes, que para serem eficazes devem ser distintos, novamente deixando claro o separatismo moderno:

- Tradução: misturas entre gêneros de seres novos, híbridos de natureza e cultura - o que ele chama de redes;

- $\quad$ Purificação: duas zonas ontológicas distintas, a dos humanos e a dos não humanos - o que ele chama de crítica.

Assim, se jamais tivéssemos sido modernos, pelo menos da forma como a crítica narra, as relações tormentosas com as outras naturezas-culturas seriam transformadas. $\mathrm{E}$ foi pela via da constituição moderna que são definidos os humanos e não humanos, suas propriedades, relações, competências e agrupamentos.

Por crer na separação total dos humanos e não humanos - em um contexto não rizomático - e por anular simultaneamente essa separação, a constituição tornou os modernos invencíveis. Tudo acontece no meio, tudo transita em as duas, tudo ocorre por mediação, por tradução e por redes, "este é todo o paradoxo moderno: se levamos em consideração os híbridos, estamos diante de mistos de natureza e cultura; se considerarmos o trabalho de purificação, estamos diante de uma separação total entre natureza e cultura" (LATOUR, 1994, p. 35).

Latour conclui que o mundo moderno nunca existiu, no sentido que jamais funcionou de acordo com as regras de sua constituição. É muito mais que uma ilusão e muito menos que uma essência. Então o pós-modernismo não seria uma solução, mas sim um sintoma, pois vive sob a constituição moderna, mas não acredita mais nas garantias que ela oferece. 
É possível relacionar com o que Lyotard (2009) chama da condição do pósmoderno, caracterizado por uma incredulidade perante 0 metadiscurso filosófico/metafísico, e principalmente suas pretensões atemporais e universalizantes.

Propõe, portanto, a expressão não-moderno (ou amoderno) que é todo aquele que leva em conta ao mesmo a constituição dos modernos e os agrupamentos de híbridos que ela nega.

A condição moderna acabou de tentar justapor, sem conectá-los, estes três grandes repertórios da crítica: a sociedade, a natureza e o discurso. Caso sejam mantidos distintos e separados, formam a imagem do mundo moderno: uma natureza e técnica homogêneas, uma sociedade feita de reflexos, falta aparências e ilusões, um discurso constituído somente de efeitos de sentido separados de tudo.

A síntese é impossível enquanto permanecermos modernos, já que a natureza, o discurso, a sociedade, o ser nos ultrapassam infinitamente, e que esses quatro conjuntos só podem ser definidos através de sua separação, a qual mantém nossas garantias constitucionais.

Reais como a natureza, narrados como o discurso, coletivos como a sociedade, existenciais como o ser, tais são os quase-objetos que os modernos fizeram proliferar, e é assim que nos convém segui-los, tornando-nos simplesmente aquilo que jamais deixamos de ser, não modernos.

Para se restabelecer a simetria, um possível caminho é o que Latour (2012) desenvolveu na Teoria ator-rede (TAR), que é uma forma de entender o conhecimento considerando os atores humanos e atores não humanos. A teoria possui um aspecto heterogêneo, que sugere que os efeitos causados pelas redes são diversos e não somente humanos.

Para ele, o social não pode ser construído como material ou domínio, e "assumir a tarefa de fornecer uma "explicação social" de algum outro estado de coisas" (LATOUR, 2012, p. 17). Dessa forma, "tenciono, pois, redefinir a noção de social remontando a seu significado primitivo e capacitando-o a rastrear conexões novamente. Então, poderemos retomar o objetivo tradicional das ciências sociais, mas com instrumentos mais bem ajustados à tarefa" (LATOUR, 2012, p. 18). 
A teoria do ator-rede considera variáveis tanto os atores humanos quanto os não humanos, buscando romper a divisão sujeito-objeto para pensar a crise da ação do sujeito sobre a natureza. Assim, para Latour, a rede é um conceito e não uma coisa, é como uma ferramenta que facilita a descrição de um fenômeno que está sendo descrito, de forma que "esses movimentos com a participação de máquinas e humanos potencializaram conhecimentos e compartilhamentos" (PASSARELLI, 2010, p. 164).

Latour formulou a teoria pensando a realidade comunicativa em rede considerando as formas de hibridação e mediação de tal forma que a verdade e o erro, a natureza e sociedade, humanos e não humanos são considerados igualmente:

Mais que verdadeira e propriamente uma teoria, de acordo com o próprio pensador, a teoria "ator-rede" é um estudo baseado em noções de simetria, de tradução e de "método" e é interpretado como um caminho para a construção e fabricação dos fatos, segundo a qual, tanto a natureza como a sociedade deveriam ser analisadas através de um comum quadro de interpretação. (...) Segundo Latour, a palavra actor limita-se aos significados humanos, já o termo actant (atuante), termo emprestado da semiótica, permite incluir os elementos não humanos no interior da definição e saber que o ator é também produtor de subjetividade, não importa em qual perfil manifeste sua ação-expressão em rede. (PASSARELLI, 2010, p. 168)

Sobre o lugar desses atores (actantes) é importante ressaltar que:

Se é um grande equívoco metodológico restringir de antemão e no lugar do ator o alcance das entidades que devem povoar o mundo social, seria tanto ou mais patético não reconhecer o trabalho incansável que fazem para limitar o repertório dos actantes e manter as controvérsias a distância. Uma vez mais, ainda que se tenha tornado um pouco irritante, o único lema viável é "seguir os próprios atores". Sim, cumpre segui-los quando multiplicam entidades e também quando as reduzem. (LATOUR, 2012, p. 25)

A atualização se justifica, pois o actante é tudo aquilo que gera e movimenta a ação, e pode ser tangível ou não tangível, colocando como quase sujeitos e quase objetos softwares, pessoas, informações e arquivos, de forma que ocorra uma hibridização nessas associações. E reitera que a todo instante é necessário o movimento de reformulação das concepções a que estava associado, "pois a definição anterior se tornou praticamente irrelevante" (LATOUR, 2012, p. 23). Justificando da seguinte forma: 
O senso de integração entrou em colapso. Mas para registrar a percepção da crise e acompanhar as novas conexões, outra noção de social tem de ser descoberta: bem mais ampla do que a usualmente chamada por esse nome e, ao mesmo tempo, estritamente limitada à busca de novas associações e ao esboço de seus agregados. Este é o motivo pelo qual definirei o social, não como um domínio especial, uma esfera exclusiva ou um objeto particular, mas apenas como um movimento peculiar de reassociação e reagregação. (LATOUR, 2012, p. 25)

Os atores não são hierarquizáveis nem com posições rígidas, ou seja, podem tornar-se intermediários como mediadores e vice versa, categorizados apenas pela ação, se produzem modificações na rede ou não. Esse tipo de metodologia diante do estudo da tecnologia nos é bastante estimado uma vez que as transformações são em ritmo acelerado.

Sobre o nome teoria do ator-rede, Latour entende que este é um nome histórico, deselegante e confuso que não teria sentido em ser conservado, estava disposto inclusive a alterá-lo. Pontua que:

Eu estava disposto a trocar esse rótulo por outros mais elaborados como "sociologia de translação", "ontologia actante-rizoma", "sociologia de inovação" etc.; mas uma pessoa me observou que o acrônimo ANT (Actor-Network Theory) era perfeitamente adequado para um viajante cego, míope, viciado em trabalho, farejador e gregário. Uma formiga (ant) escrevendo para outras formigas, eis o que condiz muito bem com meu projeto! Idealmente, a palavra sociologia funcionaria melhor, mas não pode ser empregada antes que seus dois componentes - o que é social e o que é ciência - sejam de algum modo remontados. (LATOUR, 2012, p. 28)

Portanto, entende-se o papel atribuído aos não humanos, como atores e não projeções simbólicas e que o corpus teórico abraça estudos que atribuem a não humanos uma ação mais "aberta que a tradicional causalidade natural - e mais eficiente que a simbólica" (LATOUR, 2012, p. 29). Existe um esforço bastante generoso da teoria, no sentido de proposição, não de acusação e de desmentir outras teorias sociais. Convida o leitor a sobreviver com uma estranha dieta, de se alimentar de controvérsias sobre a constituição do social, e:

A viagem com a ANT, lamento dizer, será penosamente lenta. Os movimentos serão a todo instante interrompidos, embaraçados, suspensos e desviados pelos cinco tipos de incerteza. No mundo que a ANT tenta percorrer, nenhum deslocamento parece possível sem traslados caros e cansativos. Os sociólogos do social parecem pairar como anjos, transportando poder e conexões quase imaterialmente, 
enquanto o estudioso da ANT tem de arrastar-se como uma formiga, carregando seu pesado equipamento para estabelecer até o mais insignificante dos vínculos. (LATOUR, 2012, p. 47)

Há de se fazer uma escolha no caminho epistemológico a ser trilhado, ou seguir os teóricos sociais e começar a jornada determinando de início que tipo de grupo e nível de análise será enfatizado, ou adotar os procedimentos dos atores e sair pelo mundo "rastreando as pistas deixadas pelas atividades deles na formação e desmantelamento de grupos" (LATOUR, 2012, p. 51).

Outra questão levantada é a respeito dos meios de produzir o social, se esses são encarados como intermediários ou mediadores, sendo assim, o primeiro "é aquilo que transporta significado ou força sem transformá-los: definir o que entra já define o que sai” (LATOUR, 2012, p. 65) e o segundo, "não podem ser contados como apenas um, eles podem valer por um, por nenhuma, por várias ou uma infinidade. O que entra neles nunca define exatamente o que sai; sua especificidade precisa ser levada em conta todas as vezes" (LATOUR, 2012, p. 65).

O mediador tem um papel complexo e contraditório, Latour exemplifica com a utilização de um computador, que em estado perfeito de funcionamento é um intermediário e quando quebra, torna-se um mediador "pavorosamente complexo" (LATOUR, 2012, p. 65).

Essa flutuação é o que o autor chama de constante incerteza quanto à natureza íntima das entidades que ora se comportam como intermediários, ora como mediadores e são incontáveis:

Para a ANT, não há um tipo preferível de agregados sociais, existem incontáveis mediadores e, quando estes são transformados em fiéis intermediários, não temos aí a regra, mas uma exceção rara que deve ser explicada por algum trabalho extra - usualmente a mobilização de ainda mais mediadores! (LATOUR, 2012, p. 67)

Essa flutuação na ANT é importante, pois permite o trânsito entre várias camadas de análise, sejam no nível macro e no micro.

Assim, é uma perspectiva que sugere que todos os atuantes estão em uma rede heterogênea e inclui os não-humanos como actantes que também interferem na forma social, ocasionando mediações e fluxos. A rede é o caminho da ANT, em que é: "mais 
flexível que a noção de sistema, mais histórica que a de estrutura, mais empírica que a de complexidade, a rede é o fio de Ariadne destas histórias confusas." (LATOUR, 1994, p.8)

Os efeitos dos vínculos entre esses actantes é o que mais nos interessa, em como ocorrem esses fluxos e interferências mútuas, além da perspectiva da caixa preta em que se mantem o movimento e acionam os microatores e os macroatores, Latour entende que todo actante é em si uma caixa preta e, portanto, todos podem ser abertos e revelar articulações e associações em rede.

Essa reformulação é um esforço generoso diante da produção científica que mais abre para outras possibilidades do que realiza conclusões rígidas. Pensando sobre esse movimento entre os atores humanos e não humanos, temos o estudo das literacias de mídia e informação.

\section{5) Literacias de mídia e informação (MIL - Media and Information Literacy)}

O paradigma digital abriu um leque de possibilidades e em contrapartida exige dos sujeitos/usuários que se adaptem a essas demandas, pensando nas relações híbridas e de mediação entre os atores humanos e não humano.

$\mathrm{Na}$ literatura acerca do tema, McLuhan (1995) refletiu a respeito das literacias, afirmando que "o presente objeto é elucidar a efetiva causalidade da escrita fonética como forma de criar novos tipos de percepção" (MCLUHAN, 1995, p. 131) de tal forma que para sociedades letradas não é fácil entender as não letradas nas dimensões da percepção. O entendimento de literacia para ele está mais no contexto educacional, de aprendizado relativamente a ser letrado, pelo contato com a tecnologia da escrita. Tanto que afirma que é a literacia que dá as pessoas o poder de focar pouco na frente de uma imagem e conseguir entender a imagem completa apenas com um relance (MCLUHAN, 1995, p. 132).

Dessa forma é possível entender que a tecnologia tem o potencial de estender os sentidos e criar uma nova tradução da cultura que ocorre rapidamente quando uma nova tecnologia é interiorizada (MCLUHAN, 1995, p. 134). É importante entender a literacia como esse conjunto de habilidades e competências para que os indivíduos consigam adaptar-se ao contexto contemporâneo. 
O conceito de literacia passou por diversas alterações ao longo de mais de cinquenta anos e isso se deve à mudança do termo canônico ligado principalmente a práticas de ensino e práticas escolares, “literacy”, proveniente da língua inglesa, era geralmente traduzido como alfabetização ou letramento.

Mora (2014) afirma que o conceito de literacias caminhou das noções tradicionais como leitura e escrita para uma noção mais ampla apesar de entender que ler e escrever são complementares e, portanto, não podem ser separadas.

Além disso:

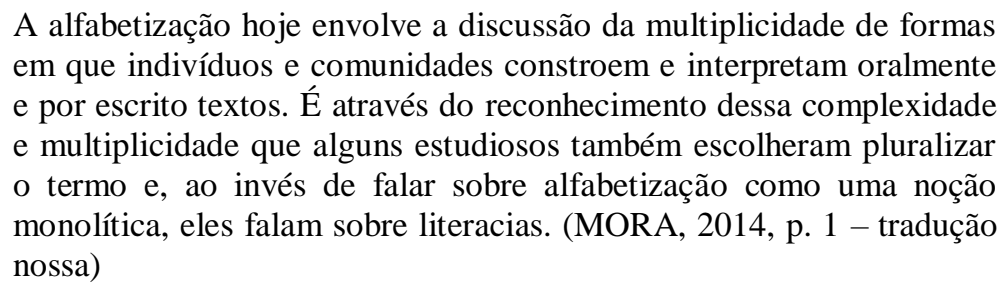

A expansão do termo implica uma ampliação do conceito entendendo de que forma a sociedade percebe a produção textual atualmente, requerendo uma "integração de outros signos e modos de expressão" (MORA, 2014, p. 1 - tradução nossa). Assim, a literacia estuda como os indivíduos produzem os textos com base nos novos modos de expressão que transcendem e complementam o texto. De tal modo que "na definição de literacia, há também um interesse para explorar e entender como os textos hoje devem aparecer como possibilidades para capacitar e facilitar comunicação equitativa entre sociedades e comunidades" (MORA, 2014, p. 1 - tradução nossa).

Para Passarelli (2009):

É de se esperar que o mérito de tais mudanças não venham apenas das
possibilidades apresentadas pelas ferramentas, mais das apropriações
criativas propostas por seus usuários (sejam eles alunos, pais ou
professores) ao lidar com elas. Tais apropriações têm sido
preconizadas por uma geração sempre online que ocupa espaços
informacionais para expandir amizades, aprender e disseminar o
conhecimento entre os amigos, produzir e tornando públicas suas
escolhas, perfis e preferências. E os espaços híbridos, agora não mais
estéreis uma vez que apropriados, tornam-se campos de inovação à
medida que adquirem as possibilidades que as pessoas lhes aplicam
através de novas ferramentas e novas ideias. (PASSARELLI, 2009, p.
6)

Para a autora o paradigma da rede a expressão da subjetividade abre muitas possibilidades e mediações para "transformar a realidade social por meio de um processo comunicativo com consequências sociais" (PASSARELLI, 2009, p. 7). A 
respeito dos nativos digitais - geração $\mathrm{Z}$ - afirma que o tempo que gastam interagindo através das ferramentas de comunicação oferecidas tem em si o potencial de criatividade "que gera efeitos colaterais como aprendizagem autodirigida, aprimoramento do uso das ferramentas (literacia digital) e desenvolvimento de interesses permanentes" (PASSARELLI, 2009, p. 7).

Constrói-se, portanto uma realidade sociotécnica híbrida:

\begin{abstract}
A classificação e ordenação do mundo e a interpretação das relações sociais segundo indicadores matemáticos e estruturais convivem com as avaliações qualitativas das relações potencializadas pela rede. Cada vez mais experimentamos uma realidade sociotécnica construída em um ambiente híbrido: uma rede física (de cabos) e lógica (de softwares) imbricada numa rede de relacionamentos na qual se constroem e se divulgam novas percepções, conhecimentos, atitudes e personas. (PASSARELLI, 2010, p. 65)
\end{abstract}

Esse contexto é de uma convergência das mídias e que se trata de mais do que uma mudança tecnológica: "ela altera a relação entre tecnologias existentes, industriais, mercados, gêneros e públicos. Modifica a lógica pela qual a indústria midiática opera e pela qual os consumidores processam a notícia e o entretenimento" (PASSARELLI, 2010, p. 68).

Tal alteração na estrutura de conhecimento causou uma nova configuração econômica e social que se dá: "por meio da economia do compartilhamento e da produção por pares, incorporada, portanto, pela noção de redes emergentes" (PASSARELLI, 2010, p. 68) e o que se mostra fundamental para a reflexão é em como a rede não se limita apenas a mais uma forma de comunicação, mas como uma fronteira do pensamento, delineamento de um novo paradigma. E inclusive foi um conceito que começou a ser defendido pela UNESCO “a partir de 2008 como um arcabouço teórico para a formação dos professores como agentes de mudança e cidadania digital" (PASSARELLI; GOMES, 2020, p. 264).

Paradigma esse que começa a ser percebido como de redes múltiplas com abertura para expressão da subjetividade e para mediações que transformam a "realidade social por intermédio de um processo comunicativo com consequências sociais" (PASSARELLI, 2010, p. 164).

Pautando assim que:

Este mar infinito de informações trouxe consigo a possibilidade da conectividade contínua, da horizontalização das relações sociais, da 
interatividade instantânea, da desintermediação, da hibridização de saberes e práticas, da mobilidade e do compartilhamento das ações comunicacionais que, a reboque da citada revolução não mais comporta a dualidade emissor-receptor do século passado. (PASSARELLI, GOMES, 2020, p. 254)

Passarelli distingue duas ondas na sociedade em rede: na primeira onda residia a questão da inclusão digital, e na segunda, vivida atualmente, na qual existem os nativos digitais, e assim, a preocupação principal não é o aprendizado de ferramentas básicas, mas sim as diferentes formas de apropriação e produção de conhecimento na web.

Entendendo essas alterações sistêmicas, a produção de conhecimento busca um deslocamento do foco teórico e por isso a importância da perspectiva das literacias que “configura, portanto, uma nova abordagem para os estudos da cultura das redes, na qual a linguagem multimídia da tela se torna o meio mais comum de comunicação e entretenimento" (PASSARELLI, 2010, p. 73).

Dessa forma, o conceito de literacia é caracterizado por indicar a habilidade de usar a informação de maneira efetiva e criativa. O momento de transição da cultura letrada para o que é a cultura das mídias e da convergência é marcada pela interatividade e pela não linearidade e assim, o conceito de literacia se expande:

No espectro das Literacias de Mídia espera-se desenvolver habilidades
como: pensamento crítico; decifrar as mensagens midiáticas para
desestimular atitudes consumistas; reconhecer diferentes versões do
mesmo fato; reconhecer as técnicas de persuasão em uso; descobrir
partes da história que não estão sendo contadas; avaliar as mensagens
midiáticas à luz de nossas crenças e experiências; criar e distribuir
nossas próprias mensagens e lutar por justiça na mídia.
(PASSARELLI; GOMES, 2020, p. 264)

Gilster (1997) cunhou o termo literacia digital para "designar a habilidade de entender e utilizar a informação de múltiplos formatos e proveniente de diversas fontes quando apresentada por meio de computadores" (apud PASSARELLI, 2010, p. 74).

Eshet-Alkalai (2004) mapeou as literacias e as dividiu em cinco grandes grupos que buscam abarcar as principais habilidades cognitivas e não cognitivas necessárias para se desenvolver em ambiente digital. São elas: fotovisual, pensamento hipermídia, reprodução, socioemocional e da informação.

De forma que podemos aproveitar para atualizar o conceito para Transliteracias, como definido abaixo: 
A reboque da evolução exponencial dos recursos da tecnologia digital no imbricamento da IoT, Big Data e Inteligência Artificial destaco como Terceira Onda Informacional a evolução do conceito de Literacias de Mídia e Informação para Transliteracias -a habilidade de ler, escrever e interagir entre diferentes plataformas digitais, artefatos e meios de comunicação, utilizando desde a oralidade ao desenho, linguagem escrita, mídia impressa, rádio, Tv, vídeos, filmes e redes sociais. (PASSARELLI; GOMES, 2020, p 269)

A transliteracia quando compreendida como conjunto de práticas sociais e não somente como simples habilidade cognitiva, depende uma série de recursos como, por exemplo, artefatos físicos - como livros, jornais e computadores -, conteúdo relevante transmitido pelos meios acessados, habilidade apropriadas, conhecimento e atitudes advinda dos usuários, tipos mais adequados de suporte sociais e da comunidade (PASSARELLI, 2010, p. 75).

Sendo de natureza complexa e multifacetada faz com que seja cognitiva, mas também de cultura, poder e política, de forma que é necessário o investimento em projetos educacionais voltados para utilização da web e das redes sociais, haja vista que as literacias são também conhecimento adquirido.

Para Purcell-Gates e Perry (2008), são sempre embebidas por instituições sociais considerando como "um constructo ideológico oposto a habilidades autônomas, separados dos contextos de uso. Sob essa perspectiva, sua natureza ideológica reflete o fato que a literacia é sempre construída e ativada em grupos sociais e contextos políticos e sujeita a implicações de relações de poder" (PURCELL-GATES; PERRY, 2008, p. 5 - tradução nossa).

Assim, as autoras entendem que, a partir dessa perspectiva, o desenvolvimento da literacia não é visto como linear, mas de forma a construir uma habilidade e fluência em direção a um tipo de literacia não-hierárquica. É vista como múltipla e complexa e socialmente e culturalmente situada, e a literacia escolar ou acadêmica é uma de muitas literacias, sendo assim a questão social bastante importante uma vez que não é possível homogeneizar.

Sobre as habilidades apropriadas se mostra importante correlacionar com os chamados nativos digitais, que tem um grande potencial criativo e operam na aprendizagem autodirigida dos dispositivos, com habilidade de compreensão da informação e de sua produção.

Nesse sentido, vale uma investigação sobre a geração $\mathrm{Z}$ e motivo da utilização do termo geração no âmbito da comunicação, uma vez esse conceito foi bastante 
utilizado em pesquisas que tratavam sobre aspectos culturais e políticas, como por exemplo, a geração chamada hip-hop e, mais recentemente, no que tange desenvolvimentos tecnológicos, tal como a geração millenium (ou Y) e a geração Z

Feixa e Leccardi (2010) afirmam que a noção de geração se desenvolveu em três momentos históricos, em três quadros sociopolíticos particulares: durante os anos 1920, o período entre guerras; durante os anos 1960, a época do protesto; e novamente a partir dos anos 1990, com a emergência da sociedade em rede, ao qual falam sobre a sobreposição geracional, "isto corresponde à situação em que os jovens são mais habilidosos do que as gerações anteriores em um centro de inovação para a sociedade: a tecnologia digital" (FEIXA; LECCARDI, 2010, p. 186).

A utilização do termo não pode ser de forma esvaziada e redutora, entendendo principalmente o que os críticos atribuem que:

\begin{abstract}
Muitos estudos são desenvolvidos a partir de uma perspectiva que contempla uma determinada geração de forma isolada, como uma espécie de unidade desconectada de outras gerações e de seu tempo histórico. Percebe-se uma certa inflação do conceito seguida de uma destituição de seu sentido teórico na medida em que o termo geração passou a ser utilizado, muitas vezes, como sinônimo para denominar uma faixa etária ou um grupo com características específicas. (MOTTA, WELLER, 2010, p. 175-176)
\end{abstract}

Nesse sentido, uma questão crucial na discussão sobre a utilização do conceito de geração é principalmente quando se acentua o sentido histórico, categorizando o pertencimento a uma geração ao mesmo ano de nascimento, como se significasse uma predisposição para algum tipo de modalidade específica do viver e pensar.

O que se colocou como essencial para a definição da utilização de geração nessa pesquisa foi de que os sujeitos que passam a ser entendidos como pertencentes de uma geração específica não precisam ser classificados a partir do fator nascimento no mesmo tempo cronológico, mas de participar dos mesmos acontecimentos e dos mesmos conteúdos de vida e acima de tudo de fazê-lo a partir do mesmo padrão de estratificação de consciência (MOTTA; WELLER, 2010, p. 176). Ou seja, intenta-se fugir da noção limitante e determinista de geração e utilizar no sentido de agrupar e entender que sim os jovens da geração $\mathrm{Z}$ estão mais familiarizados por estarem inseridos no paradigma digital desde que nasceram, e que dessa forma não conhecem outra lógica, sendo sua aprendizagem digital. 
É necessária a existência de uma força social que se constitui a partir da vivência desses sujeitos que entendem e desenvolvem perspectivas similares acerca de determinadas vivências:

\begin{abstract}
Segundo Mannheim, é preciso existir uma conexão geracional entre os mesmos, ou seja, um tipo de participação em uma prática coletiva, seja ela concreta ou virtual, que produz um vínculo geracional a partir da vivência e da reflexão coletiva em torno dos mesmos acontecimentos. $\mathrm{O}$ autor chama ainda a atenção para o fato de que em uma mesma conexão geracional existem distintas unidades geracionais que correspondem a diferentes perspectivas ou posições em relação a um mesmo acontecimento. (MOTTA; WELLER, 2010, p. 177)
\end{abstract}

Assim, para Mannhein, o que forma uma geração não é uma data de nascimento comum - a "demarcação geracional" é algo "apenas potencial"-, mas é a parte do processo histórico que jovens da mesma idade-classe de fato compartilham (a geração atual) (FEIXA; LECCARDI, 2010, p. 189). Com tal característica, a utilização do conceito de geração faz com que os tempos históricos sejam fixados "em relação aos tempos da existência humana e entrelaçados com a mudança social" (FEIXA; LECCARDI, 2010, p. 190).

A forma como a juventude orienta-se diante da mesma problemática histórica estabelece uma conexão geracional e o que estabelece essa relação não necessariamente são os conteúdos em si, mas as "tendências formadoras de um coletivo surgidas a partir da apropriação desses conteúdos" (MOTTA; WELLER, 2010, p. 177).

Para os autores, torna-se crucial ao estabelecer essa delimitação geracional romper com ideias de grupos homogêneos e sem complexidade e centrar as análises nos conteúdos, ações e expressões destes grupos, destacando especialmente a questão de classe e acesso a essas literacias.

A respeito da juventude, propõem:

Cabe refletir sobre o real conteúdo das experiências juvenis, sobre o que elas informam, sem violar seu caráter individual ou coletivo, suas especificidades de gênero, de geração, de pertencimento étnico/racial, seus lugares ou não lugares em meio a um universo que torna cada vez mais difícil definir o que é real e o que é virtual, o que caracteriza um estilo ou modo de vida local e o que passou a ser incorporado a partir de outras interseções. (MOTTA; WELLER, 2010, p. 183) 
Não é uma relação de oposição às gerações anteriores, apesar da necessidade de um envolvimento de algum tipo de comparação. Pesquisas da década de 2000, priorizam as condições simultâneas e inter-relacionadas das influências do desenvolvimento nacional e internacional, haja vista que com a globalização uma constelação de contradições ficou em evidência e marca profundamente esses indivíduos, tal como novas desigualdades relativamente ao mundo do trabalho e as formas de relacionamentos (FEIXA; LECCARDI, 2010, p. 199).

Portanto, a geração Z é definida por fatores cosmopolitas, de conexão:

Isso é ilustrado com base em três "constelações geracionais": 1. A geração migratória (marcada pelos processos de migração transnacional); 2. A geração aprendiz (marcada pelo trabalho precário); e 3. A geração colcha de retalhos (marcada por processos de hibridização cultural). Nestas três áreas (demográfica, econômica e cultural), a geração mais jovem (ou qualquer de suas frações) atua como um barômetro das novas tendências. (FEIXA; LECCARDI, 2010, p. 199)

Floridi (2014) refere-se como geração $\mathrm{Z}$ aquela que "não apenas por causa das duas gerações alfabéticas $\mathrm{X}$ e Y anteriores, mas também por causa da zettabyte de dados disponíveis para eles. Para pessoas pertencentes à geração Z, o mundo sempre foi wireless" (FLORIDI, 2014, p. 44 - tradução nossa). É uma geração que foi nascida onlife. Além disso, são pautados pela constância da informação imagética, afundados em imagens advindas das redes sociais, das buscas, de todos os dispositivos.

Desse modo, em uma pesquisa sobre o uso das tecnologias da informação e comunicação (TIC), realizada no ano 2019 pelo Centro Regional de Estudos para o Desenvolvimento da Sociedade da Informação (Cetic.br ${ }^{1}$ ), é possível construir um panorama geral de como se dá o uso das tecnologias no Brasil, principalmente como estão os indicadores em relação à conexão dos jovens e entender como existem diversas desigualdades, muitos Brasis com realidades diferentes, considerando que quando se fala em literacias o aspecto social é indissociável, uma vez que nada é homogêneo.

Esse recorte de direcionar o olhar para a geração $\mathrm{Z}$ e como se dão as relações dos jovens com as literacias destaca a questão do acesso e o quanto são desiguais em

\footnotetext{
1 Fonte: CGI.br/NIC.br, Centro Regional de Estudos para o Desenvolvimento da Sociedade da Informação (Cetic.br), Pesquisa sobre o uso das tecnologias de informação e comunicação nos domicílios brasileiros - TIC Domicílios 2019.
} 
quesitos de distribuição de renda, reiterando assim que existem diversas formas de acesso às tecnologias que são permeadas por políticas e questões sociais.

Por exemplo, no indicador domicílios com acesso à internet em relação à proporção urbana é maior, assim como o uso no sudeste e no centro-oeste são mais expressivos do que no norte do país. É relevante nesse contexto os números de usuários de internet por dispositivo utilizado, colocando o aparelho smartphone como preferido e em como jovens de 10 a 15 anos e 16 a 24 anos utilizam de forma brutalmente mais intensa do que outras faixas etárias.

Outra pesquisa importante voltada para um âmbito comercial, realizada no ano 2018 pela Box 1824 - empresa em tendências em consumo, comportamento e inovação - que intentou mapear as tendências da geração Z, ao entrevistaram jovens de 14 a 22 anos, em seis regiões do Brasil provenientes das classes A, B e C.

Definem, portanto, o conceito de geração como um grupo de pessoas que tem a mesma faixa etária e que partilham de cenários econômicos, políticos, culturais e tecnológicos. Dessa forma "as configurações de mundo de cada época direcionam esse grupo de pessoas a vivência de experiências comuns e adoção de valores e comportamentos similares. Esse conjunto de traços parecidos é o que molda uma geração" (BOX1824, 2018, n.p.).

A geração $\mathrm{Z}$ é a geração de jovens que já são nativos digitais e que, de acordo com a pesquisa realizada, se caracterizam pelo nascimento de 1994 a 2010. Por não conheceram o mundo sem internet, não realizam a separação entre online e offline, estão aptos a viverem realidades múltiplas e simultâneas e são hipercognitivos ${ }^{2}$, como na descrição abaixo:

Por serem nativos digitais, quando crianças já recebiam uma avalanche de informações visuais e auditivas totalmente diferentes das gerações anteriores, que tiveram que se adaptar à internet e dividem a realidade em offline e online. Para a geração $\mathrm{Z}$, tanto faz se é físico ou virtual: os dois são reais. O que antes parecia oposto, agora é complementar. Relações verdadeiras acontecem tanto pessoalmente quanto pela rede. Tudo isso influencia diretamente a velocidade com que processam tudo, e até mesmo como acontecem suas sinapses. (BOX1824, 2018, n.p.)

\footnotetext{
2 Pesquisa completa disponível em: http://pontoeletronico.me/2018/true-gen-a-geracao-da-verdade/.
} Acesso em: 05 de jun. 2019. 
Esses jovens já estão integrados à internet das coisas, não tem dúvidas quanto os wearables, sendo "a dimensão do tempo e conceito de memória são diferentes para eles. Não é preciso ocupar espaço mental com aquilo que já está disponível nos dispositivos que os acompanham a todo minuto" (BOX1824, 2018, n.p.).

A internet das coisas (ou IoT) seriam os objetos inteligentes, de modo que estão conectados em rede e com o usuário e apresentam sensores que se adaptam às condições exteriores e podem realmente ser qualquer tipo de objeto, relógios, smartphones, geladeiras, carros, etc. e produzem informação o tempo todo.

Esses jovens são "super informados, pés no chão e priorizam a estabilidade" (BOX1824, 2018, n.p.). Tem no âmago do seu comportamento a vontade de expressar as suas verdades, por isso a transparência é um valor obrigatório, não é opcional. É esse público também que produz muito conteúdo e está constantemente atualizado nas tendências tecnológicas, de hardwares, de design, de redes sociais e dos videogames.

Para essa geração, o modo de vida contemporâneo, no regime 24/7, é o modelo que conhecem em que todas as camadas são sobrepostas, não há divisões entre lazer, trabalho e descanso, nem tampouco entre consumir e produzir, o que são os chamados prosumers.

Han entende o papel ativo desses prosumers, em que "todos são simultaneamente remetentes e destinatários, consumidores e produtores" (HAN, 2018, p. 16) de forma que não fica muito claro se existe uma hierarquia entre remetente e destinatário, sugerindo a "substituição do conceito do usuário passivo para o navegadorprodutor" (PASSARELLI; GOMES, 2020, p. 254).

Conceitos anteriores da teoria da comunicação já não são mais aplicáveis, uma vez que:

Hoje não somos mais destinatários e consumidores passivos de informação, mas sim remetentes e produtores ativos. Não nos contentamos mais em consumir informações passivamente, mas sim queremos produzi-las e comunicá-las ativamente nós mesmos. Somos simultaneamente consumidores e produtores. Esse duplo papel aumenta enormemente a quantidade de informação. (HAN, 2018, p. 36) 
Há também uma incredulidade diante do que podemos entender como os metarrelatos de Lyotard (2009). Esses jovens não acreditam nos grandes conceitos caros ao pensamento moderno, como totalidade, razão, sujeito e progresso. Por serem ultra informados e conectados, questionam esses grandes discursos, buscam heterogeneidade de elementos, o que se perde em grandiosidade, se adquire em tolerância.

Podemos entender que essa geração é um possível caminho para o que Latour nomeia de antropologia simétrica, uma vez que não concebem uma sociedade compartimentalizada, dividida e separada em caixinhas, mas sim uma imagem de mundo conectado, seja na sociedade e natureza, nas relações e nas conexões. Ou seja, nada é homogêneo e sem conflitos para esses jovens da geração $Z$, por isso é tão importante buscar analisar como se dão essas mediações com e entre eles. Assim, "enquanto condição da cultura nesta era caracteriza-se exatamente pela incredulidade perante o metadiscurso filosófico-metafísico, com suas pretensões atemporais e universalizantes. O cenário pós-moderno é essencialmente cibernético informático e informacional" (BARBOSA, 2009, p. viii). 


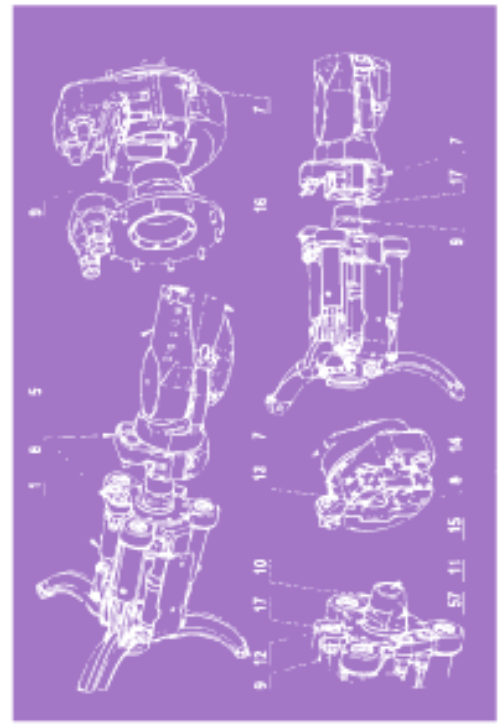

Capítulo II - Breve desenvolvimento da linguagem realidade aumentada 


\section{CAPÍTULO II - BREVE RETROSPECTICA DO DESENVOLVIMENTO DA LINGUAGEM REALIDADE AUMENTADA}

Realizado um entendimento da sociedade hiperconectada, híbrida e onlife, podemos aprofundar no segundo capítulo, no qual se realiza um percurso pelas definições da realidade aumentada, criando uma noção geral sobre suas diferenças, aproximações com virtual reality. Essas definições que vem sendo realizadas desde a década de 1990 e atualizadas devido a constante alteração e desenvolvimento em parâmetros até então não atingidos. A discussão sobre o uso intensificado da tecnologia no cotidiano pode abarcar um grande leque de linguagens e suas consequências derivadas. No recorte delimitado da pesquisa, escolhemos a realidade aumentada, realidade mista ou, como colocado por alguns pesquisadores, realidade mediada, haja vista que se trata de uma realidade que é alterada, de forma a potencializar a percepção atual da realidade.

\section{1) As definições de Realidade aumentada}

É necessária uma delimitação do que de fato se trata a realidade aumentada enquanto definição técnica. Essa seria, de forma simplificada, a inserção de objetos virtuais no ambiente físico, mostrada ao usuário em tempo real, a partir da intervenção de um dispositivo tecnológico, que conecta pela interface o ambiente chamado de real e o ambiente virtual, de forma a visualizar e manipular objetos virtuais, sejam essas em movimento ou não, permitindo uma intervenção bastante imersiva para o sujeito envolvido.

Basicamente, é uma sobreposição de áudios, imagens, gráficos, todo tipo de inserção sensorial virtual sobre o tempo real. O que torna maior o seu atrativo é a possibilidade de uma interação e, por consequência, imersão interativa muito profunda em relação com a tecnologia.

A primeira menção futurística literária do que viria a ser a realidade aumentada, acredita-se que foi no romance de 1901 do autor L. Frank Baum, “The Master Key” uma narrativa das aventuras de um jovem adolescente de quinze anos que busca os mistérios da eletricidade. 
Em determinado momento, o menino recebe uma série de presentes de um demônio, sendo um deles chamado Character Marker, em português algo como marcador de caráter:

Consiste neste par de óculos. Enquanto você os usa, todos que encontrar serão marcados em suas testas com uma letra indicando seu caráter. Os bons ostentarão a letra 'B', o mal a letra 'M.' O sábio será marcado com um 'S' e o tolo com um 'T.' O amável mostrará um 'A' na testa e o cruel a letra 'C'. Assim, você pode determinar por um único olhar a verdadeira natureza de todos aqueles que encontrar. (BAUM, 1901, p. 94 - tradução nossa)

O menino, ao tomar nas mãos os óculos, questiona se há eletricidade em sua construção e quem o descobriu, e recebe como resposta: "é um fato que sempre existiu, mas agora é utilizado pela primeira vez" (BAUM, 1901, p. 95 - tradução nossa).

No entanto, as bases técnicas para a linguagem foram surgir apenas décadas depois, nos anos 1960, com as pesquisas de Ivan Sutherland, que desenvolveu uma aplicação nomeada de Sketchpad que realizou pela primeira vez uma manipulação de figuras tridimensionais na tela do computador.

Utilizava um display com um visor óptico localizado na cabeça do usuário que era rastreado por um dos dois rastreadores, um mecânico e outro ultrassônico. Considerando seu contexto, foi de fato revolucionário o desenvolvimento dessa pesquisa, porém, devido às limitações computacionais da época, foi delineado apenas um protótipo, como uma diagramação possível a ser realizada. É possível perceber pela foto do dispositivo o quanto era de grande dimensão e pouco confortável.
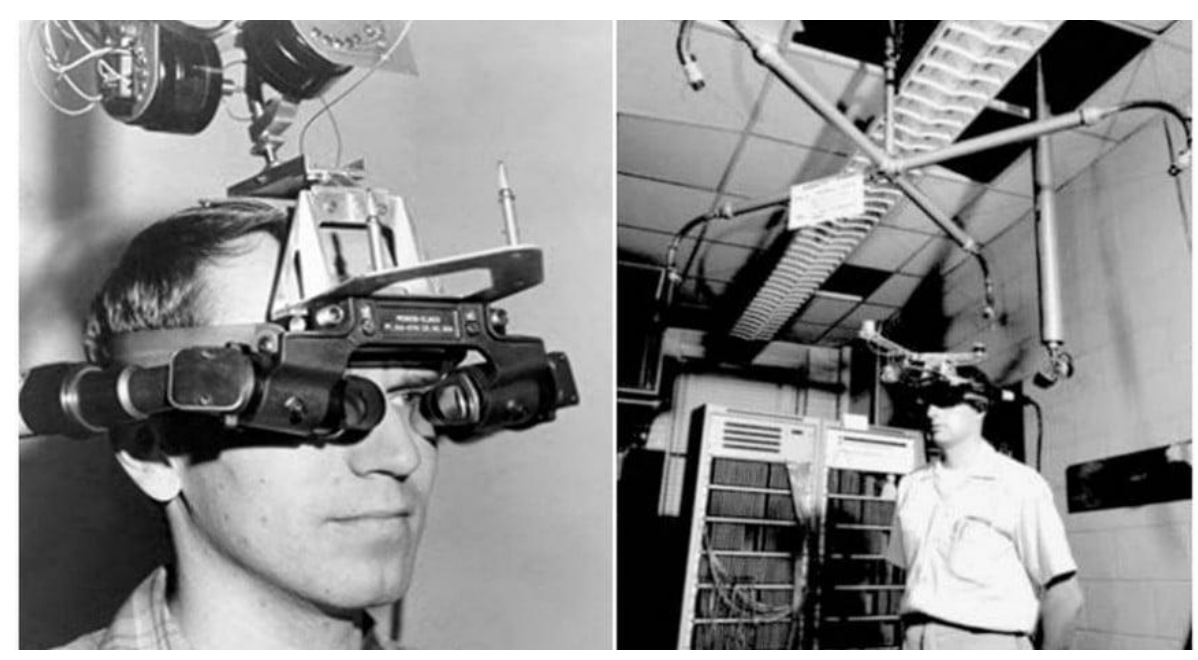

Figura 1: visor óptico projetado por Sutherland 
Algumas décadas depois houve um crescimento exponencial, a partir dos anos 2000, do uso da realidade aumentada a partir dos dispositivos móveis, especificamente os celulares smartphones e os tablets e mais recentemente em dispositivos wearables, em que:

\begin{abstract}
A habilidade de armazenar, manipular e recuperar informação muito rapidamente, com aparelhos disponíveis de forma quase onipresente, como os computadores, notebooks, tablets e smartphones, combinada com uma rede de ligação de grande penetração que conecta todos esses aparelhos, faz com que a linha entre o real e o que é simulado seja cada vez mais tênue. (GOMIDE, 2017, p. 125)
\end{abstract}

Para Lanier (2017), Sutherland não tinha a extravagância de McLuhan, mas sua influência sobre os meios foi a mais intensa na década de 1960: "eu amo ver os primeiros passos da ciência computacional, pois é possível perceber como todo o campo dos computadores é um ato de invenção" (LANIER, 2017, p. 43 - tradução nossa).

Lanier é um dos precursores da realidade virtual e afirma que "nossos cérebros não estão presos em um lugar, são plásticos e adaptáveis. Não somos alvos fixos, mas processos criativos" (LANIER, 2017, p. 50 - tradução nossa). Portanto, valoriza absolutamente a cognição humana diante das tecnologias virtuais, de forma que a "percepção humana sempre será nutrida e vai aprender modos de entrar mais profundamente na realidade física" (LANIER, 2017, p. 50 - tradução nossa). Assim, quanto mais há desenvolvimento e progresso das tecnologias virtuais, mais os humanos se tornarão detetives e aprender truques para distinguir ilusões da realidade.

Uma das diferenças que se entende entre realidade virtual e realidade aumentada é que a virtual não é sobre simular a realidade, mas sim sobre estimular expectativas neurais, de forma que é uma tecnologia que confia na complementação dos vácuos pelo cérebro, cobrindo os erros do simulador.

Assim, a partir dessas possibilidades no desenvolvimento da técnica, vários pesquisadores propuseram suas definições e terminologias, das quais destacamos as mais relevantes e que mostram a diversidade dentro da área.

Kirner (2008), afirma que realidade mista é a sobreposição de objetos virtuais gerados pelo computador com o ambiente físico, mostrada ao usuário, em tempo real, com o apoio de algum dispositivo tecnológico. Realidade misturada apresenta assim 
duas modalidades: realidade aumentada e virtualidade aumentada (KIRNER, 2008, n.p. - tradução nossa). Assim, "realidade aumentada é assim denominada porque objetos virtuais (produzidos e projetados pelo computador) são inseridos num ambiente físico, sugerindo assim uma ampliação deste contexto pelo acréscimo de objetos virtualmente construídos" (KIRNER, 2008, n.p. - tradução nossa).

Entende-se que esta possibilita a inclusão de objetos virtuais em ambientes reais, de forma a facilitar a interação e imersividade em tempo real. Tecnicamente, portanto, é necessário:

\footnotetext{
- Sensor(es) para determinar o estado do mundo físico onde a aplicação será colocada;

- Processador para avaliar os dados do sensor, para implementar as "regras da natureza" e outras regras do mundo virtual, e para gerar os sinais requeridos para exibição;

- Display de exibição adequado para criar a impressão que o mundo virtual e o mundo real coexistem e para colidir os sentidos do participante de forma que ele ou ela percebam a combinação do mundo físico e virtual. (CRAIG, 2013, p. 40 - tradução nossa)
}

Assim,

Os sensores em geral são usados para localizar o participante no mundo físico por meio de rastreadores e para mapear pontos do ambiente. Podem ser usadas câmeras, microfones, emissores de luz e de som, GPS, acelerômetros, giroscópios, dispositivos sensíveis ao toque, ou qualquer outro tipo de sensor, separadamente ou em conjunto, para compor o rastreador. (GOMIDE, 2017, p. 128)

Essa nova escala de fatores introduzida na sociedade é absolutamente potencializada com o digital, que realmente estendem nossas capacidades tanto físicas quanto espaciais. Assim, nessa perspectiva, as tecnologias tais como realidades virtuais, aumentadas e mistas causaram estiramento de limites.

O uso da linguagem de realidade aumentada não se limita apenas à sua conceituação e aplicação técnica, mas também para uma ampliação metafísica de sua utilização, abrindo possibilidades inúmeras de discussão sobre as fronteiras entre o virtual e o real.

O limiar entre o real e o virtual, retoma um dos maiores questionamentos filosóficos que se trata da compreensão da realidade, no sentido de tentar responder por meio da percepção o que existe no mundo. Assim, essas relações perceptivas são 
totalmente mediadas por uma série de atores: indivíduos, estruturas, instituiçõos e tecnologia, retomando, a teoria ator-rede de Latour.

O questionamento da realidade foi inquirido de forma extensiva por filósofos, sociólogos e escritores. O filósofo grego Platão, com a teoria do mundo das ideias, criou uma possível relação entre duas realidades, uma do mundo concreto e uma segunda chamada de mundo das ideias, na qual estaria a verdade essencial das coisas. Além da filosofia, a literatura também investigou incessantemente as fronteiras do real, especialmente nas produções de ficções científicas, que partindo da especulação e da imaginação trabalham dentro de um grande leque de possibilidades, assim como percebido no romance de L. Frank Baum.

Para Passarelli (2010) "não há mais separação entre o artificial e o natural, o virtual e o real. A subjetividade na rede é um espaço de possibilidades para conversações e intervenções sociais" (PASSARELLI, 2010, p. 167). A partir dessa fundamentação, começa-se a pensar sobre a realidade aumentada, haja vista que ao propor uma realidade aumentada ou virtual, propõe outra realidade concomitante à inicial, absolutamente mediada pelo dispositivo tecnológico e que podem ser realidades que se contaminam e se influenciam constantemente.

Markley (2001) questiona o que afinal conta como espaço virtual, no sentido de que o ciberespaço se tornou um termo muito amplo e utilizado para tudo desde jogos como gameboy, até cada computador que é considerado como um portal para as sombras do universo infinito, um espaço acessível eletrônico (MARKLEY, 2001, p. 298 - tradução nossa).

Para ele, o ambiente virtual busca imitar a complexidade de uma experiência proprioceptiva e se torna uma metáfora imperialista, um buraco negro textual que de forma absolutamente irônica faz com que a realidade virtual ainda permaneça como uma ficção semiótica, haja vista que para mergulhar de fato em uma realidade credível o sujeito precisa imaginar um mundo simulado muito mais complexo do que o mundo real tenta representar (MARKLEY, 2001, p. 301 - tradução nossa).

Acredita então que: "é somente por entender tecnologias virtuais dentro da história que o ciberespaço procura negar ou transcender que vamos começar a sonhar com um tipo diferente de 'real"' (MARKLEY, 2001, p. 302 - tradução nossa). 
Comumente associada como a linguagem da realidade virtual, mostra-se importante a diferenciação entre os conceitos, e a virtual seria "uma interface avançada para aplicações computacionais, onde o usuário pode navegar e interagir em tempo real, em um ambiente tridimensional gerado por um computador, usando dispositivos multissensoriais" (KIRNER, 2008 n.p. - tradução nossa).

Rush (2006) entende que: "em realidade virtual, o aspecto ainda passivo de observar a tela é substituído pela imersão total em um mundo cuja realidade existe contemporaneamente com a do observador" (RUSH, 2006, p. 202), para ele, a utilização do termo observador é limitante, por isso propõe usuário, referindo-se a uma experiência tridimensional simulada que reage a seus movimentos e ações, ou seja, são participantes ativos.

Milgram et al. (1994) define a realidade aumentada como realidade mista, já que está em um lugar entre os extremos de um ambiente chamado de virtual e um ambiente chamado de real. Propõe uma linha didática na qual teriam gradações de uma realidade aumentada e uma virtualidade aumentada, nomeada de Reality-Virtualy $(R V)$ Continnuum, como no diagrama ilustrado abaixo.

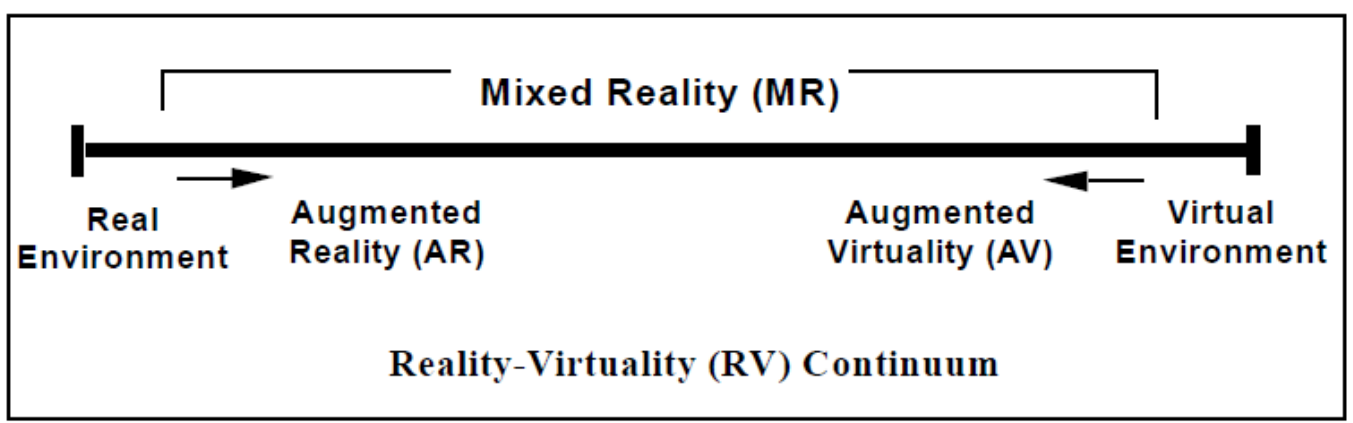

Figura 2: Representação simplificada da RV Continuum ${ }^{3}$

$\mathrm{Na}$ tradução para o português, real environment é ambiente real; augmented reality $(A R)$ é realidade aumentada; mixed reality $(M R)$ é realidade mista; augmented virtuality $(A V)$ é virtualidade aumentada; e virtual environment é ambiente virtual.

\footnotetext{
${ }^{3}$ Fonte: MILGRAM, Paul; TAKEMURA, H., UTSUMI A., KISHINO, F. Augmented Reality: A class of displays on the reality-virtuality continuum (1994).
} 
Para Milgram et al, a realidade aumentada e a virtual estão bastante relacionadas e podem ser considerados conceitos juntos ao invés de considerá-los antíteses, é mais conveniente colocá-los como polos em extremidades opostas de um continuum, como observado acima.

No caso do lado mais esquerdo do continuum, define-se qualquer ambiência que consiste em objetos reais e que podem ser observados no que os autores chamam de mundo real. Mais para a direita definem as ambiências que consistem somente de objetos virtuais, aos quais incluem como exemplo os gráficos computacionais das simulações, sejam baseadas nos monitores ou imersivas. Dessa forma, o meio do diagrama é uma ambiência na qual o mundo real e o virtual são apresentados juntos em somente uma exibição.

Assim, três características são primordiais para a identificação da linguagem, sendo essas a combinação do real e do virtual, a interatividade em tempo real e estar em terceira dimensão, “a habilidade de gerar e renderizar a terceira dimensão (3D) graficamente levou a uma habilidade de criar cenas que não eram possíveis de serem criadas puramente no mundo físico" (CRAIG, 2013, p. 6 - tradução nossa). Importante realizar a distinção entre dispositivos que utilizam apenas terceira dimensão, tal como os cinemas e brinquedos, sendo que esses não são em realidade aumentada haja vista que o usuário apenas recebe o conteúdo já pré-programado, não é em tempo real nem tampouco se altera por decisões do sujeito.

Milgram propõe que a realidade aumentada e a virtualidade aumentada são relacionadas e é bastante válido considerá-los juntas. O autor conceitua que existem duas categorias de exibição de realidades aumentadas, são essas a transparente e a com base no monitor.

A definição da exibição chamada de transparente (see-through) é:

Esta classe de monitores é caracterizada pela capacidade de ver através do meio de exibição diretamente para o mundo em torno do observador, alcançando assim tanto o máximo possível de presença quanto o máximo grau de "imageamento do espaço real". O acréscimo mais comum da exibição é obtido usando espelhos para sobreponha gráficos gerados por computador de forma óptica em cenas do mundo real diretamente visualizadas. Tais exposições já são uma tecnologia madura em alguns sistemas de aviação (principalmente militares), como em painel ou monitores montados na cabeça (HMD's), mas atualmente estão encontrando novas aplicações como uma tecnologia relacionada à $\mathrm{RV}$, especialmente em ambientes 
de manufatura e manutenção. De especial interesse são os esforços recentes para aplicar essas imagens de RA à imagiologia médica, através da sobreposição de dados adquiridos através de técnicas de como ultrassom, tomografia computadorizada, etc. de acordo com o paciente real. (MILGRAM, 1994, p. 284 - tradução nossa)

No caso dos displays ou exibição baseada em monitores, a definição do autor é a seguinte:

\begin{abstract}
Usamos o termo baseado em monitor (não imersivo), ou "janela-nomundo" (WoW) na realidade aumentada para se referir a sistemas de visualização onde as imagens geradas por computador são, analogicamente ou digitalmente, sobrepostas em imagens de vídeo armazenadas. Embora a tecnologia para alcançar isso seja bem conhecida há um tempo, principalmente por meio de chroma-keying, um grande número de aplicativos úteis se apresentam quando este conceito é implementado estereoscopicamente. (MILGRAM, 1994, p. 284 - tradução nossa)
\end{abstract}

Assim, realiza as seguintes perguntas no intuito de definição do que é a exibição, ao qual chama de substratum:

- O ambiente está sendo observado principalmente como real, com melhorias adicionais geradas por computador? ou

- O ambiente circundante é principalmente virtual, mas aumentado através do uso real (ou seja, sem imagem)?

No caso da resposta da segunda questão, o que é chamado de virtualidade aumentada (R.V.), em referência a ambientes de display completamente gráficos, ou seja, totalmente imersivos. Algumas extensões podem ser incluídas nas situações virtuais, tais como a inserção de objetos reais, como a mão do usuário que pode ser colocada no mundo gráfico, para apontar ou agarrar algo, o que propõe um desafio para as questões perceptivas.

Nesse sentido, o que é mais marcante dessa discussão proposta por Milgram é o desenvolvimento de uma taxonomia para a mixagem do real e do mundo virtual. Dentro da realidade mista, muitos fatores podem ser elencados no âmbito da distinção entre realidade aumentada (R.A.) e virtualidade aumentada (R.V.), sendo que, para o autor, 
O que é necessário é criar uma taxonomia com a qual o ambiente principal, ou substrato, diferentes sistemas RA / VR podem ser representados em termos de um hiperespaço multidimensional (mínimo). Três (mas não são as únicas três) propriedades importantes deste hiperespaço são evidentes a partir da discussão neste artigo:

- realidade; isto é, alguns ambientes são basicamente virtuais, no sentido de que foram criados artificialmente, por computador, enquanto outros são principalmente reais.

- Imersão; ou seja, ambientes virtuais e reais podem ser exibidos sem a necessidade de observador para ser completamente imerso dentro deles.

- Exatidão; isto é, se os objetos do mundo primário são vistos diretamente ou por meio de processo de síntese.

A taxonomia tridimensional que propomos para misturar mundos reais e virtuais é baseada nestes três fatores. (MILGRAM, 1994, p. 284 tradução nossa)

Mostra-se absolutamente relevante atualizar para a contemporaneidade, haja vista que a conceituação de Milgram foi realizada no ano de 1994 e a partir dessa data o desenvolvimento das tecnologias digitais foi exponencial. No entanto, o texto ainda se mantém importante especialmente no que toca a definição e terminologias.

Lemos (2013) afirma que existem dois modos de aplicações de realidade aumentada, um indoor não locativo e outro que utiliza objetos do espaço urbano, o outdoor, que usa a geolocalização:

O primeiro tipo de aplicações de RA, indoor, é o que caracteriza a simulação a partir de objetos criados em 3D - que podem estar em qualquer lugar - e que são usados como superfície para "aumentar" a realidade do objeto. Um mapa pode virar uma cidade 3D para simulação de trânsito, uma foto de uma molécula pode aparecer em 3D em uma disposição manipulável de átomos no espaço etc. Aqui o lugar da experiência importa pouco já que não são sensíveis aos contextos locais. (...) A cidade é o lugar da interação. Nessas experiências, a informação "aumenta" a realidade de um objeto (artefato, monumento, símbolos etc.), sendo diretamente vinculada ao contexto local e ao posicionamento do usuário. Nesse caso, podemos dizer que a RA constitui-se como um serviço, usando tecnologias baseadas em localização (Locationbased technologies, LBT). O espaço urbano é o "board" da experiência. (LEMOS, 2013, p. 5)

O espaço urbano como base da experiência do usuário, o chamado outdoor, é bastante utilizado em aplicativos de videogames, como o Pokémon GO, que será analisado mais à frente.

Bower, Lee e Dalgarno (2017) propõem a nomenclatura ambientes colaborativos de realidade mista, nos quais "permitem que os participantes em um espaço virtual 
imersivo (como o mundo virtual) e participantes em um espaço físico, interajam um com o outro em tempo real” (BOWER, LEE, DALGARNO, 2017, p. 407).

Sobre essa imersão, Kerckhove (2009) comenta a respeito de um filme de ficção científica no qual o ator principal acorda sem saber se estava acordando de ou em uma fantasia total. Isso se dá, pois, as memórias recém-construídas eram tão realistas que não conseguia distinguir a ficção da realidade. Entende que essa confusão mais cedo ou mais tarde poderá acontecer com qualquer indivíduo, não é somente em um futuro distante distópico hollywoodiano, mas que "para parar com a experiência bastar-lhe-ia tirar os fones e desligar o computador" (KERCKHOVE, 2009, p. 56).

A respeito da simulação, Kerckhove afirma:

\begin{abstract}
De fato a história da simulação computacional é a da entrada gradual num ambiente tátil. Das duas para as três dimensões, e daí para o rápido desenvolvimento provocado pelas sensações de força e feedback, estamos sendo sugados para um vértice eletrônico rico em texturas. $\mathrm{O}$ apelo da tecnologia eletrotátil lembra o mito das sereias de Ulisses, com suas intensas conotações eróticas. A RV é como uma sereia que nos arrasta para um mar de elétrons. (KERCKHOVE, 2009, p. 62)
\end{abstract}

Outra perspectiva é a de Laurentiz (2010), para a autora:

Simulação, por exemplo, é um termo muito usado pela área da tecnologia, mas que reflete o mesmo paradoxo do dualismo 'coisas e signos' (ou se preferirem, 'matéria e mente') reduzindo-se o processo da semiose, que é triádica por excelência. Além disso, simular, quando usado como 'aquilo que finge ser o que não é', também vem carregado de vícios fenomenológicos que são consequência direta do que vimos até agora apontar sobre o conceito de realidade. Sem falar da clássica distinção entre virtual versus real. (LAURENTIZ, 2010, p, 1746-47)

Essa realidade criada ou simulada é algo que pode ser tocada e sentida, "agora podemos juntar com o pensamento 'a mão da mente"'. Penetrando na tela com a luva virtual, a mão real transforma-se numa metáfora técnica, tornando tangíveis as coisas que anteriormente eram apenas visíveis. (KERCKHOVE, 2009, p. 63).

$\mathrm{O}$ autor conclui que "com a manipulação de objetos 3D em tempo real, o pensamento e o processamento estão se tornando a mesma coisa" (KERCKHOVE, 2009, p. 65). É um processo simbiótico de conexão e imersão criando o que ele chama de consciência simultânea partilhada, uma relação visceral que em longo prazo 
acarretará uma mudança psicológica da exteriorização da consciência pessoal, pois dessa forma, "o mundo exterior vai tornar-se uma extensão da consciência, tal como costumava acontecer com as culturas 'primitivas'. Isto ditará, não o fim, mas o afastamento do Homo theoreticus do centro da ação, substituído pelo Homo participans." (KERCKHOVE, 2009, p. 68)

Com tal característica transformativa é considerável o conteúdo da estética digital bem como a nostalgia por sua ausência, o exemplo disso é a experiência estética da simulação e a forma como se relaciona com a experiência física: "experiência da simulação em um mundo virtual são ontologicamente distintas daquelas que se dão no mundo primário. Contudo, o impacto dessas experiências podem ser simulares no efeito" (JACKSON, 2001, p. 348 - tradução nossa).

Se o usuário sente psicologicamente um efeito de enjoo após uma simulação de voo, então os sentidos foram enganados a acreditar que de fato estavam voando. Afirma então que as novas mídias são tão reais quanto o clima e seus efeitos afetam coletivamente as vidas de diferentes formas e de que a articulação de qualquer nova mídia deve ser cuidadosamente considerada no impacto da estrutura paradigmática em sistemas complexos.

Sobre esse mundo real e o virtual Wisnik (2018) argumenta que:

\begin{abstract}
Mas seria o mundo virtual apenas um dublê em simulacro do mundo real, uma espécie de segunda vida rebaixada, como os avatares de Second Life $e^{4}$ ? Certamente não. Está claro, hoje, que o ciberespaço é uma nova entidade midiática que se infiltra de tal como no mundo real que já não é possível separá-los completamente. (WISNIK, 2018, p. 53)
\end{abstract}

Relacionando com essa virtualidade, Quéau (1993) entende que a linguagem do virtual:

Não é simplesmente uma técnica a mais na história das representações. É, literalmente, o surgimento de uma nova escrita comparável à invenção da imprensa ou ao surgimento do alfabeto. Uma escrita interativa e imersiva que emerge nas comunidades, nas cidades e nos mundos virtuais, ou seja, na realidade virtual, sendo necessário penetrar nessa escrita, dominar sua gramática e seu estilo. (PRADO, 2003, p. 80)

\footnotetext{
${ }^{4}$ O Second Life é um mundo virtual online, desenvolvido e de propriedade da empresa Linden Lab, lançado em 2003 e ainda ativo em 2020.
} 
Os google glass, as experiências de realidade aumentada, os consoles de videogame que se movimentam a partir da captação do corpo do usuário ou sinais de $Q R$ code espalhados por estabelecimentos ou em serviços transformaram o mundo atual em um "híbrido de carne e conexão" (WISNIK, 2018, p. 53). Transformando dessa forma, os olhos humanos, eles mesmos, em uma câmera, "os olhos mesmos fazem imagens" (HAN, 2018, p. 13).

Wisnik assim retoma o conceito de Haraway (2001) sobre o ciborguismo e atualiza para os aparelhos eletrônicos multifuncionais, tais como os smartphones, que são essa espécie de lente de aumento com visão decodificadora. Portanto, "diante dessa situação de borramento dos limites entre o real e o virtual, mais uma vez, a reflexão sobre a perda de nitidez no mundo contemporâneo ganha relevância” (WISNIK, 2018, p. 53).

Fahey (2013) acredita que as definições mais comuns de realidade aumentada são restritivas e limitadas, consideram apenas o conteúdo gráfico e outros conteúdos multimídia e as visualizações de câmera e dos computadores, para ele uma melhor definição seria de que se trata da integração artificial, contínua e dinâmica de novo conteúdo ou remoção de conteúdo existente de percepções da realidade (FAHEY, 2013). Além disso, também propõe que o aumento possa ser para além da visão, de forma a englobar a audição.

Seu conceito do que é o real merece ser mencionado, no sentido de que utilizar o termo realidade é algo que diferencia primordialmente o que é realidade aumentada e realidade virtual, uma vez que no caso da primeira é a mesma realidade que todos experimentam através de seus sentidos a partir do momento em que tem consciência, ou seja, pode ser modificado e manipulado, mas existe independente dos esforços humanos. No caso da virtual, existe apenas porque foi projetado por um grupo de pessoas, assim, precisam de mais do que apenas os sentidos para a interação com o programa (FAHEY, 2013 - tradução nossa).

Azuma (1997) define realidade aumentada como uma variação de ambientes virtuais, diferenciando da virtualidade, pois essa permite uma completa imersão do usuário em um ambiente sintético e não se relaciona com o mundo ao redor, enquanto que a aumentada permite ver o mundo real com o virtual e objetos sobrepostos ou 
compostos com o mundo real. Portanto, complementa a realidade, em vez de substituí-la completamente (AZUMA, 1997, p. 2 - tradução nossa).

Coloca como definidor que além de adicionar elementos pode também remover e principalmente, a imersão e interação deve ser instantânea, o que criaria uma diferenciação entre tecnologias da indústria cinematográfica como por exemplos filmes em terceira dimensão, que não permitem alteração e intenção pelo usuário, trata-se de uma postura mais passiva, de recebimento. Ao discutir direções futuras do uso da linguagem, Azuma propõe que sistemas eficazes devem ser construídos com o desempenho em tempo real em mente, ou seja, os registros de data e hora precisos devem estar disponíveis (AZUMA, 1997, p. 32 - tradução nossa).

Manovich (2005) indica um novo termo sobre a realidade aumentada: espaço aumentado, ao qual seria um "espaço físico coberto por informações dinamicamente variáveis. É provável que essas informações estejam em formato multimídia e geralmente sejam localizadas para cada usuário" (MANOVICH, 2005, p. 2 - tradução nossa).

Sua reflexão converge no movimento de re-conceitualizar o espaço aumentado não apenas como uma tecnologia, mas como uma ideia e prática cultural e estética. Para o autor, há uma sobreposição de camadas que possibilita o monitoramento de usuários, de forma que "a entrega de informações aos usuários no espaço e a extração de informações sobre esses usuários estão intimamente ligadas. Assim, o espaço aumentado também é monitorado" (MANOVICH, 2005, p. 8 - tradução nossa).

A maior diferença entre a realidade aumentada e a realidade virtual é que a virtual trabalha com a completa simulação e a aumentada trabalha com coisas reais no espaço real, utilizando-se do espaço imediato desse usuário. Não os coloca em oposição, assim como Milgram, Manovich também entende como uma questão de escala:

Em um nível, se pensamos em uma situação específica como imersão ou aumento é simplesmente uma questão de escala - ou seja, o tamanho relativo de uma tela. Quando você assiste a um filme em uma sala de cinema ou em um monitor de TV grande, ou quando está jogando um jogo de computador em um console de videogame conectado à TV, dificilmente conhece o ambiente físico. Na prática, você está imerso na realidade virtual. Mas quando você assiste o mesmo filme ou joga o mesmo jogo na pequena tela de um telefone celular ou PDA que cabe na sua mão, a experiência é diferente. Você ainda está presente em grande parte no espaço físico e, embora a tela aumente sua experiência fenomenológica geral, ela não assume o 
controle. Portanto, se devemos entender uma situação específica em termos de imersão ou aumento depende de como entendemos a ideia de adição: podemos adicionar novas informações à nossa experiência ou podemos adicionar uma experiência completamente diferente. (MANOVICH, 2005, p. 11 - tradução nossa)

O que parece ser o mais relevante das proposições de Manovich não as definições de aumentada, mas suas derivações, tais como pensar sobre a experiência de se estar em um espaço aumentado e quais são as possíveis poéticas e estéticas desses espaços. Entender esse espaço como uma possibilidade de desenvolvimento de arquitetura que contempla camadas virtuais de informações juntamente com o espaço real já construído.

Essas múltiplas camadas retomam que a narrativa construída a partir da realidade aumentada é completamente mediada por dispositivos, pelas redes, pelos bancos de dados e pelos homens.

Dentre tantas nomenclaturas como mista, simulada e espaço aumentado, optamos por padronizar a utilização do termo Realidade Aumentada e da sigla R.A. principalmente por sua disseminação mercadológica, sendo a definição que está presente nas descrições de aplicativos, jogos e redes sociais.

\section{2) Acesso e usabilidade da realidade aumentada}

A utilização da realidade aumentada levanta muitas questões, tanto favoráveis, quanto desfavoráveis. Uma série de fatores são elencados tais como os custos, qual a usabilidade, como realizar a imersão e qual sua acessibilidade.

Inclusive, por se tratar de uma tecnologia em constante atualização e investimento de pesquisa, está sendo amplamente utilizada em outras áreas do conhecimento, nas quais implicam experiências completamente diferentes. São áreas como medicina (procedimentos cirúrgicos), publicidade e marketing (aplicativos que buscam engajar o potencial interesse dos consumidores), arte (artistas estão propondo trabalhos que só se efetivam através do smartphone, propondo uma experiência imersiva), militarmente (display de simulação de situações de guerra) e no cinema e televisão, destacadas abaixo: 


\begin{abstract}
A integração de objetos virtuais com cenas gravadas ao vivo, em ambientes externos e em tempo real, foi uma ampliação da aplicação dos cenários virtuais. Dessa maneira, símbolos da meteorologia podiam ser aplicados em mapas virtuais pelo movimento das mãos da âncora de programas sobre o clima, logos de empresas patrocinadoras da programação podiam ser integrados na cena, com a câmera em movimento, como em diversos programas esportivos. Todas essas aplicações são de realidade aumentada porque combinam o real e o virtual, são interativos em tempo real e são registrados em 3D com movimento de câmera. (GOMIDE, 2017, p. 131)
\end{abstract}

Alguns exemplos de sucesso em áreas variadas devem ser destacados, pois são importantes no sentido de trazer um panorama geral de sua aplicabilidade.

$\mathrm{Na}$ área de turismo, o aplicativo Time traveler die berliner mauer, criado por Robin Von Har, disponível nos sistemas Android e iOS, integrado a um sistema de geolocalização com um mapa da cidade de Berlim, propõe uma outra experiência diante da história da cidade. O aplicativo assinala onze pontos ao longo do muro de Berlim e quando a câmera do celular ou tablet é apontada ao local, aparece na tela imagens e cenas que se passaram exatamente ali.

Há também um aplicativo chamado Inkhunter que permite aos usuários testarem desenhos de possíveis tatuagens em suas peles, simulando a partir da utilização da câmera do smartphone como supostamente ficaria.

A marca brasileira Xalingo Brinquedos, fundada em 1947, lançou uma linha de brinquedos em realidade aumentada. A linha chamada Interactive Play é descrita no site da empresa como a união "em um mesmo produto, brincadeira física e realidade aumentada, proporcionando para a criança uma experiência ampliada de aprendizado" 5 .

São produtos que se completam no aplicativo, tal como o de desenho que depois de finalizado, a criança o captura com a câmera e interage com o desenho aumentado, ou o brinquedo de soletrar que é composto por peças de madeira desmontáveis e que ao concluir a montagem é possível fazer a leitura da peça e projeta-la no ambiente, nesse caso são projetados o objeto e a palavra.

No campo da saúde o investimento em realidade aumentada e virtual tem sido numeroso. No Brasil, a startup MedRoom, vinculada ao hospital Albert Einstein, vem

\footnotetext{
${ }^{5}$ Disponível em: http://www.xalingo.com.br/brinquedos/pt/produtos?search=interactive. Acesso em 30 de out. de 2019.
} 
desenvolvendo ferramentas para realizar a simulação de anatomia e morfologia para os alunos do curso de medicina da Faculdade Israelita de Ciências da saúde Albert Einstein. É possível investigar todo o corpo humano, isolar sistemas, aproximar ou afastar os órgãos e obter informações sobre eles. Nesse sentido, o que parece ser a maior vantagem na utilização da realidade aumentada é em como os alunos conseguem ter uma melhor noção do estudo da área, haja vista que nos livros e programas de dissecção virtual não tem tridimensionalidade, a visão fica achatada a um modelo bidimensional.

Para os profissionais do marketing e publicidade, a realidade aumentada pode potencializar a experiência do consumidor através dos aplicativos. Um caso foi da empresa sueca IKEA com o aplicativo IKEA Place que permitia aos usuários colocar e posicionar móveis dentro de suas casas. Outra vantagem era a possibilidade de compartilhar fotos e vídeos desses espaços produzidos.

\section{3) Realidade aumentada e o movimento Data Art}

A arte tem o potencial para refletir e comentar sobre mundo, "a arte pode tornar visível o invisível ou o avesso do visível? Para Paul Klee, a obra de arte expande nossa percepção do mundo para além de nós mesmos. É nesse sentido que a arte torna o mundo mais visível" (VENTURELLI; MELO, 2019, p.204). Assim, se mostrou importante buscar algum entendimento de como a arte opera nas tecnologias digitais e as tomam como material criativo principalmente como um novo caminho dentro da visualidade e da percepção.

Para Machado (2003), há vários grupos que exploram as tecnologias digitais com experiências inovadoras, dos quais destaca principalmente os artistas, que levam sempre ao extremo o diálogo com a comunicação e a tecnologia, de forma que muitos trabalhos vêm tratando de temas como a participação coletiva, a interferência nos dispositivos, as performances ao vivo, o acesso ou controle remoto, a criação de avatares, os ambientes multiusuário e a realidade virtual na rede (MACHADO, 2003, p.14), ou ainda: 
Na verdade, já nas duas últimas décadas do século XX os artistas começaram a se interessar pelo fenômeno da comunicação, concebendo experiências artísticas baseadas na transmissão/recepção interativa de textos, sons e imagens de um ponto a outro do planeta, através de telefone, slow scan TV, satélite, televisão e mais recentemente a internet. $\mathrm{O}$ primeiro movimento da história da arte a valorizar a comunicação transnacional foi a arte postal, uma espécie de pré-história da communication art. Reunindo artistas de diferentes nacionalidades para experimentar novas possibilidades de intercâmbio de trabalhos numa rede livre e paralela ao mercado oficial das artes, a mail art foi a primeira modalidade de evento a tratar como arte a comunicação em rede e em grande escala. Mas as diferenças que existem entre as primeiras experiências com arte postal e a arte telemática de hoje são a intermediação da eletrônica e as consequências advindas da adesão a essa tecnologia: alta velocidade de comunicação a distâncias planetárias, procedimentos instantâneos de comunicação, utilização de suportes imateriais, além do surgimento de questões novas para a arte, como a ubiquidade, o tempo real, a interatividade, a dissolução da autoria, a criação coletiva etc. (MACHADO, 2003, p.13)

Assim, um marco importante foi em 1994 quando Julie Martin, diretora de teatro, criou a primeira produção teatral em realidade aumentada, Dancing In Cyberspace, financiada pelo Conselho de Artes da Austrália em que os atores e dançarinos manipulavam objetos virtuais do tamanho de seus corpos em tempo real.

Esse movimento tem sido chamado de Data Art, em que são usadas características técnicas e conceituais sobre o imaginário da tecnologia e "dá lugar a um universo de dados que formam informações e conhecimentos cada vez mais abstratos" (VENTURELLI; MELO, 2019, p. 206). Essa "visualização de dados com interesses artísticos podem criar fantasia, ilusão e ficção, assim como também podem mobilizar e criar consciência crítica sobre as questões políticas e éticas inerentes à forma como os dados são capturados, analisados e utilizados" (VENTURELLI; MELO, 2019, p. 206).

Dentro desse contexto, em janeiro de 2011 um coletivo de artistas escreveu o manifest $A R^{6}$, um manifesto para arte em realidade aumentada, retomando os ismos do início do século XX com as vanguardas artísticas:

\section{O RA Art Manifesto}

A Realidade Aumentada (RA) cria realidades espaciais coexistentes, nas quais tudo é possível - Em Qualquer Lugar! O futuro da RA não tem fronteiras entre o real e o virtual. No AR Future nós nos tornamos os meios de comunicação. Liberando o virtual de uma tela estagnada, transformamos dados em espaço físico em tempo real. O vidro de

\footnotetext{
${ }^{6}$ Disponível em: http://manifest-ar.art/. Acesso em 15 de jan. de 2020.
} 
segurança da tela está quebrado e o físico e o virtual estão unidos em um novo meio espaço. Neste espaço é onde escolhemos criar. Estamos destruindo as misteriosas portas do impossível! Tempo e espaço morreram ontem. Nós já vivemos no absoluto, porque criamos presença geolocativa eterna e onipresente. No século 21 , as telas não são mais fronteiras. As câmeras não são mais memórias. Com RA, o virtual aumenta e aprimora o real, colocando o mundo material em diálogo com o espaço e o tempo. (...) Criam provocações em realidades aumentadas subliminares, estéticas e políticas, desencadeando distúrbios tecnológicos em uma substratosfera da experiência online e offline.

Permanecendo firmemente no real, expandimos a influência do virtual, integrando e mapeando-o no mundo à nossa volta. Objetos, subprodutos banais, imagens fantasmas e eventos radicais coexistirão em nossas casas particulares e em nossos espaços públicos. Com o RA, instalamos, revisamos, permeamos, simulamos, expomos, decoramos, rachamos, infestamos e desmascaramos instituições, identidades e objetos anteriormente mantidos pelos fornecedores de elite de políticas públicas e artísticas no chamado real físico. O telefone celular e os futuros dispositivos de visualização são testemunhas materiais dessas dimensões dimensionais efêmeras. Objetos, eventos pós-esculturais e arquiteturas inventivas. Invadimos a realidade com nosso espírito virtual viral. A RA não é um plano de deslocamento marcial de vanguarda, é um movimento de acesso aditivo que as camadas que relaciona e mescla. Abrange todas as modalidades. Contra o espetáculo, introduz a participação total. A realidade aumentada é uma nova forma de arte, mas é anti-arte. É primitivo, o que amplia sua potência viral. (...) (MANIFEST AR, 2011, n.p. - tradução nossa)

A primeira intervenção do coletivo foi no MoMA (Museum of Modern Art), em Nova Iorque, com o registro abaixo, e alguns conceitos levantados pelo grupo são bem importantes como principalmente a integração e o mapeamento do virtual e do real, a presença onipresente da tecnologia, a questão do sujeito como próprio meio e a mescla do tempo e do espaço. 


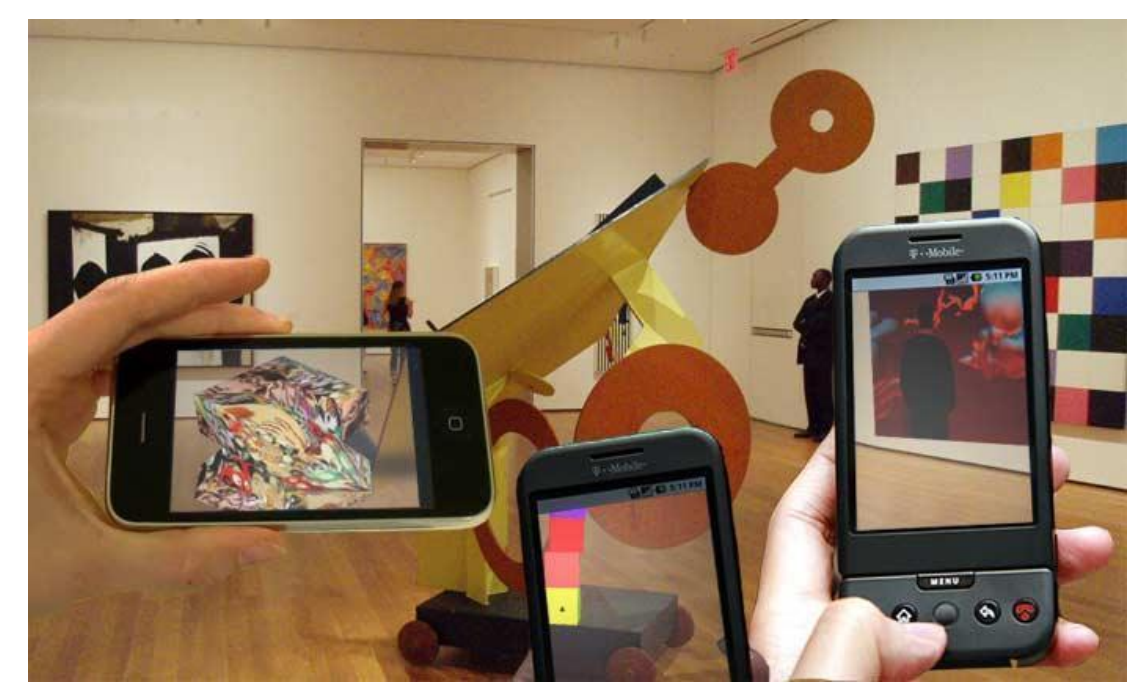

Figura 3: intervenção do coletivo manifestAR no MoMa

Em 2012, os artistas visuais Janet Cardiff e George Bures Miller realizaram na exposição de arte contemporânea dOCUMENTA (13) o trabalho "Alter Bahnhof Video Walk" foi especialmente projetado para a antiga estação de trem em Kassel, na Alemanha. De acordo com a descrição do site dos artistas, a experiência proposta foi de que os participantes podiam pedir emprestado um celular e fones de ouvido em uma cabine e então eles eram dirigidos por Cardiff e Miller através da estação.

Assim, eles criaram um mundo alternativo onde a realidade e a ficção se fundiram de uma maneira perturbadora e misteriosa. Os participantes observavam as coisas se desenrolando na tela pequena, porém existia a presença desses eventos por estarem situados no local exato onde as filmagens foram filmadas.

À medida que seguem as imagens em movimento (e tentam enquadrá-las como se fossem o operador da câmera), ocorria uma estranha confusão de realidades. Nesta confusão, o passado e o presente se confundiam e Cardiff e Miller nos guiam através de uma meditação sobre a memória e revelam os momentos pungentes de estar vivo e presente. Lembrando que não é em realizada em realidade aumentada, uma vez que todo o conteúdo já estava gravado e não acontece no momento da interação com o espectador, no entanto, é importante destacar que se trata da mesma lógica utilizada na R.A, de criar uma relação baseada na pessoalidade, orientando a percepção e o olhar de quem está ativando o trabalho, como no frame do vídeo abaixo é possível perceber. 


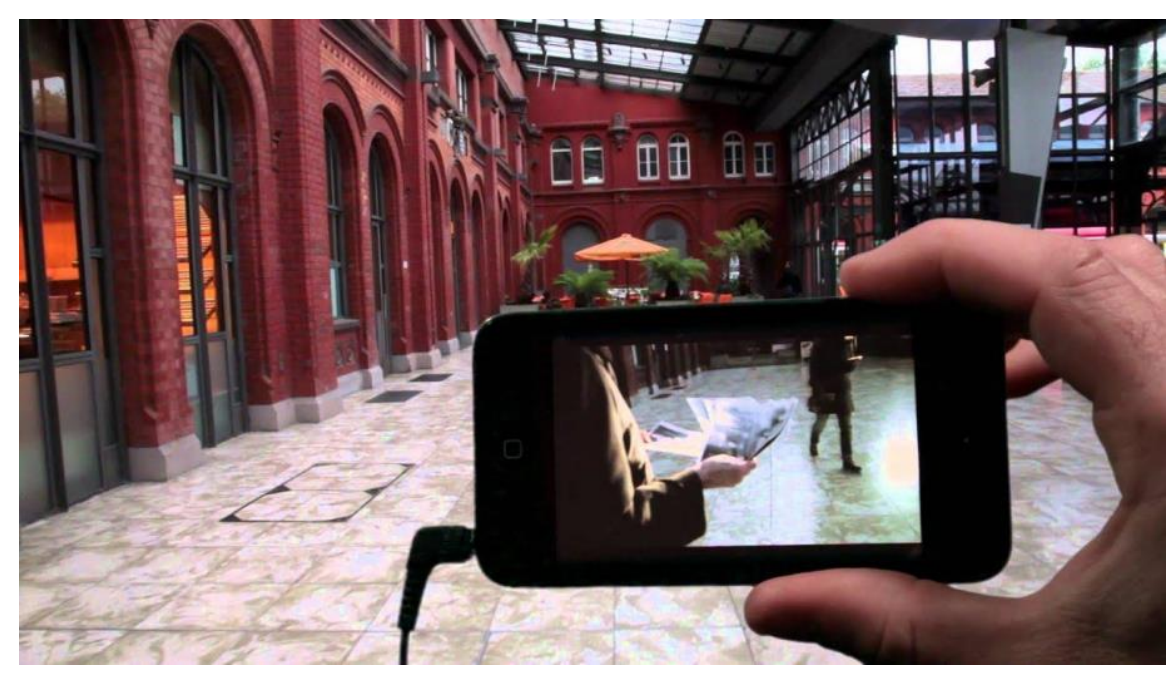

Figura 4: Frame do registro do trabalho Alter Bahnhof Video Walk (2012)

Para Manovich, os trabalhos que Cardiff vem desenvolvendo desde o começo dos anos 2000:

Eles demonstram o potencial estético de colocar novas informações sobre um espaço físico. Seu poder está nas interações entre os dois espaços - entre visão e audição (o que o usuário está vendo e o que está ouvindo) e entre presente e passado (o tempo da caminhada do usuário versus a narração em áudio, que, como qualquer mídia gravação, pertence a um tempo indefinido no passado). (MANOVICH, 2005, p. 11 - tradução nossa)

Sobre essa interação acerca do espaço, Gonçalves afirma que:

Ao interagir o espaço real e virtual por meio da realidade aumentada, o usuário poderá complementar a informação digital ao espaço físico, diluindo o limite entre as reações físicas e palpáveis e a percepção sensorial e virtual do espaço digital, potencializando o conhecimento de um dado lugar, edifício e/ou cidade, respeitando as características originais da região. (GONÇALVES, 2010, p. 143)

Em termos estéticos, pode se pensar o espaço aumentado como um caminho que ainda está sendo construído, mas que se abre para um grande leque de possibilidades: "os artistas têm um novo desafio: colocar um usuário em um espaço cheio de dados contextuais dinâmicos com os quais o usuário pode interagir" (MANOVICH, 2005, p. 15 - tradução nossa).

De forma que arquitetos, programadores e artistas podem considerar o espaço "invisível" dos fluxos de dados eletrônicos como substância e não apenas como vazio, 
mas sim como algo que precisa de uma estrutura, uma política e uma poética. (MANOVICH, 2005, p. 28 - tradução nossa).

Um conceito derivado do espaço aumentado é a arquitetura líquida ou também chamada de transarquitetura, conceito referente aos trabalhos do arquiteto Marcos Novak, que constrói espaços que questionam a arquitetura tradicional e são criações para o ciberespaço.

Com "arquiteturas líquidas", a ideia é encontrar uma arquitetura baseada no movimento; que une virtual e físico; e que, através do uso da tecnologia da informação, que cria configurações espaciais em constante mutação. Este advento no ciberespaço reforçou a surgimento de um novo conceito, que caracteriza a fusão de informação, arte e arquitetura. A ideia de ciberespaço da Novak ilustra esse novo e forte conceito de espaço. (SILVA, 2005, p. 10 - tradução nossa)

Sobre essa união virtual e física, os artistas franceses Mélanie Courtinat, Salomé Chatriot e Iseult Perrault realizam a instalação After Eden na exposição FILE Festival internacional de linguagem eletrônica de 2018 em São Paulo, de acordo com os curadores, o trabalho trata-se de:

\begin{abstract}
“After Eden” é uma instalação interativa que utiliza a realidade aumentada em pinturas acrílicas com o objetivo de dissolver fronteiras entre as formas digitais e clássicas de expressões artísticas. Jardins luxuosos florescem na arte de Iseult Perrault, enquanto que a realidade aumentada é apenas um pequeno passo para que ganhem vida. Formas, criaturas e sons lúdicos estão escondidos entre as plantas, secretamente esperando que o espectador os encontre. Embora a vegetação pareça densa e impenetrável à primeira vista, cada visitante é convidado a fazer uma viagem nesta selva viva através da realidade aumentada, uma ferramenta que permite novos níveis de realidade e compreensão. (PERISSINOTO, BARRETO, 2018, p. 49)
\end{abstract}

Abaixo um registro de como se dava o contato do público com o trabalho: 


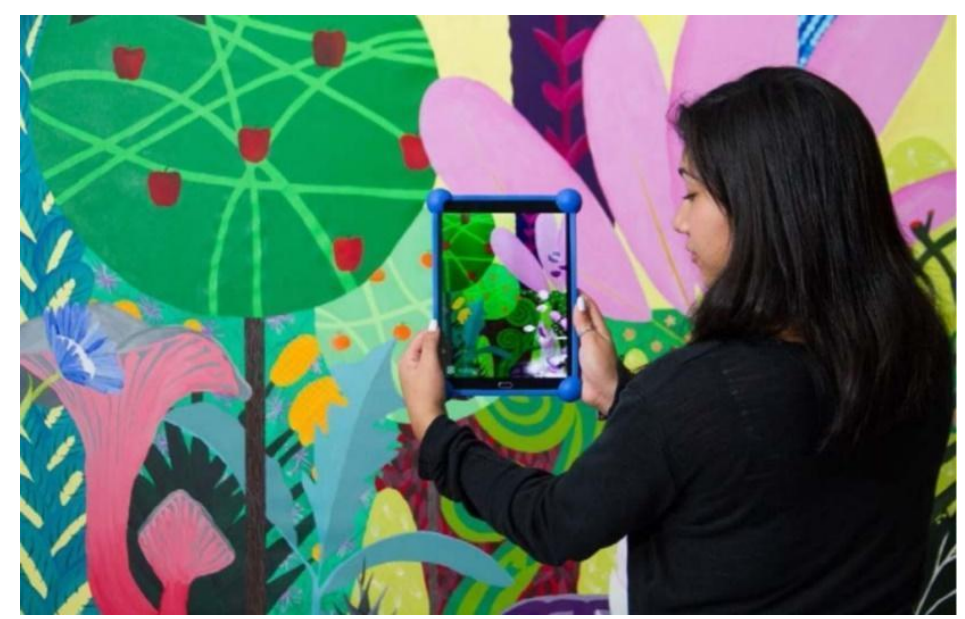

Figura 5: Registro instalação After Eden no catálogo FILE 2018 - O corpo é a mensagem

No mesmo ano de 2018, realizaram uma mostra do FILE online, na qual havia um aplicativo criado pelo Veejays Collective chamado Virtual Bedroom que propõe a possibilidade de se entrar em pinturas como do artista Vincent van Gogh:

Como seria entrar nesse quadro e andar por lá? "Virtual Bedrooms" permite que as pessoas experimentem exatamente isso! Como bônus, o espectador pode visitar Edvard ('O Grito') Munch na sala ao lado. Com nosso aplicativo, o Amsterdam Van Gogh Museum foi o primeiro no mundo a apresentar pinturas trazidas à vida através da Realidade Virtual. (FOGLIATO, 2018, p. 141)

É criada uma arquitetura da informação, de formas dentro do contexto do ciberespaço que são direcionadas para os usuários e auto organizadas pelo sistema cibernético, de forma que o espaço se torna programável e o ambiente absolutamente fluido. Esse espaço é "de informação tecnologicamente construída, onde a produção da informação resulta em envolvimento, interação e interação do espectador com espectador e do espaço com o trabalho" (SILVA, 2005, p. 26 - tradução nossa).

Para Ascott (2003), as relações mediadas pelas tecnologias computacionais "nos fornecem a capacidade de um sensoriamento remoto para investigar muito mais longe o espaço cósmico e as profundezas na matéria no nível quântico mais profundo" (ASCOTT, 2003, p 223 - tradução nossa).

Vai para uma discussão para além da imagética, mas também da construção de um novo sistema sensorial para ser compreendido:

Também não é suficiente entender o quão dependente estamos do aprimoramento da imagem, tratamento de dados e gráficos, com a rápida atualização que implica, para negociarmos um universo composto de transformações de energia que operam em comprimentos 
de onda ou intensidades muito além da capacidade de nossa escassa sistema sensorial para apreender. É muito mais do que tudo isso, suas implicações para o crescimento humano e a criatividade podem ser declarada de maneira simples: as redes de computadores fornecem um campo interação entre inteligência humana e artificial, envolvendo simbiose e integração de modos de pensar, imaginar e criar que, desde o ponto de vista do ponto de vista da arte, pode levar a uma imensa diversidade de transformações culturais, e que, em ciência e filosofia, pode produzir definições enriquecidas do ser humano condição. As redes de computadores, em suma, respondem à nossa profunda desejo de transcendência - alcançar o imaterial, o espiritual - o desejo de estar fora do corpo, fora da mente, para exceder as limitações de tempo e espaço, uma espécie teologia biotecnológica. (ASCOTT, 2003, p 223 - tradução nossa)

Para o autor, o que isso tudo oferece é uma oportunidade não apenas para construir novas realidades, mas para entrar "nas realidades dos outros, a interpenetração de universos paralelos do discurso. Nossa imersão em redes globais eletrônicas pode levar a uma reavaliação do status da realidade" (ASCOTT, 2003, p 223 - tradução nossa). De forma que existem muitas realidades coexistentes, todas construídas virtuais, de certa forma, mas principalmente dependentes de nossa participação ativa em sua construção.

Refletindo sobre essas múltiplas realidades virtuais, o artista suíço Marc Lee questiona o aspecto narcisista da cultura do selfie na era digital, criando um ambiente misto virtual de imagens e realidade, interagindo com o visitante, o incitando a tirar selfie e isso ajuda a construir essa nova realidade. Há uma crítica direta as redes sociais que potencializaram essa cultura narcisista:

Conforme podemos observar na cultura do selfie, há uma propagação do egoísmo e do narcisismo: enviamos "mini-eus" no, cada vez mais importante, espaço virtual da sociedade, para que assim os outros conheçam quem somos e, sobretudo, o que gostaríamos de ser. Ficção, fantasias, exibicionismo, confissões, autoindulgência, solipsismo são os temas e os condutores de nossa vida virtual, elementos moldados em nossa realidade (percebida) e irresponsavelmente explorados por empresas e pela mídia; Em desejos e fantasias que nos afastam da realidade. (PERISSINOTO, BARRETO, 2019, p. 26)

Essa cultura do selfie fica evidente na instalação abaixo até nos próprios movimentos do público que ativava o trabalho. 


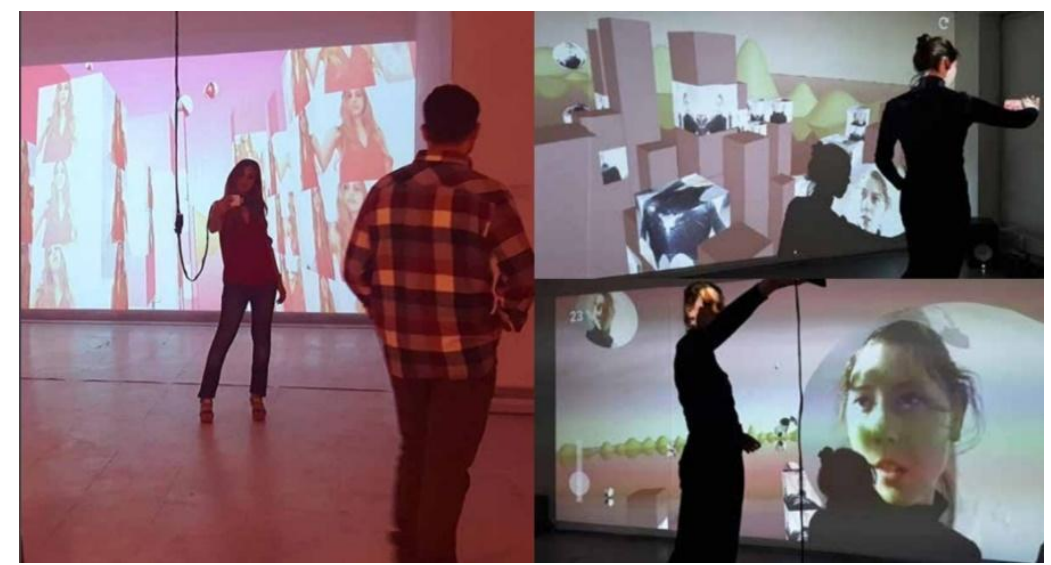

Figura 6: Registro instalação Me, Myself \& I no catálogo FILE 2019 - 20 anos de FILE 20 anos de arte e tecnologia

Outro conceito importante relacionado à arquitetura da informação é o de ciberflâneur que transpõe o indivíduo flâneur para o ciberespaço:

O flâneur é o indivíduo que caminha lentamente e sem objetivos definidos pelas ruas das grandes cidades. Sua origem remonta ao século XIX, na França, mais especificamente na Paris no tempo do Segundo Império. Desde seu surgimento nas ruas parisienses ele tem sido descrito por diversos autores, sendo que dentre os mais reconhecidos estão o poeta francês Charles Baudelaire e o filósofo alemão Walter Benjamin. O flâneur surgiu durante uma época de profundas transformações no espaço urbano de Paris e foi retratado como o observador da vida cosmopolita que nascia nas ruas. (GERALDO, 2010, p. 125)

Assim, a figura do flâneur é bastante temporal, voltada ao século XIX e a modernidade francesa, Geraldo (2010) aponta que o sujeito ciberflâneur também aparece em um contexto de grandes transformações, dessa vez a partir da popularização das novas mídias na década de 1990 e "um dos aspectos explorados na caracterização da flânerie virtual é o movimento errante do flâneur. Se o flâneur era o observador que caminhava sem objetivos definidos, o ciberflâneur se torna o usuário que clica aleatoriamente em links" (GERALDO, 2010, p. 126). Importante que seja pontuado que quando se conceitua o Ciberflânerie não se limita a uma persona, mas sim a um estado transitório de navegação que pode ser assumido virtualmente por qualquer usuário da rede (GERALDO, 2010, p. 126).

Assim, há quase um embate entre os dois tipos de flâneur como se o ciberflâneur fosse um substituto para o flâneur offline, o que na verdade se mostra redutor, haja vista que com o hibridismo há um cruzamento entre as instâncias digitais e 
físicas de forma que "parece possível imaginar o ciberflâneur conceitualmente como uma figura cuja experiência não se restringe ao ciberespaço. Hoje somos capazes de visualizar este cruzamento entre espaços físicos e virtuais" (GERALDO, 2010, p. 126).

O intuito é de aproximar a flânerie urbana e a ciberflânerie:

O ciber-flâneur torna-se observador que olha sem julgar, que busca a imersão e não a compreensão, que clica desesperadamente sendo levado a novos espaços digitais. Estamos falando de um comportamento habitual dos internautas: clicar em links de forma mais ou menos aleatória. Assim como existe o flâneur e o passante eficiente das cidades (como ilustrado por Baudelaire e examinado por Benjamin), existe também o internauta objetivo e o ciber-flâneur caótico. Desta forma, falar de ciber-flânerie não aniquila a relação objetiva, funcional e eficiente que esse mesmo ciber-flâneur possa ter com a rede em outros momentos. (LEMOS, 2001, p.2)

Lemos retoma a figura do flâneur desinteressado ao relacionar em como o usuário se aproxima e se distancia ao mesmo tempo "do nômade urbano high-tech com seu smartphone e sistemas de RA" (LEMOS, 2013, p. 9). Esse retorno à figura do flâneur é particularmente importante quando se questiona a potência da criação de novas realidades, tal como é pensado por Wood (2010) que defende a noção de que esses sistemas de realidade aumentada podem ser utilizados para na verdade mascarar a realidade, no que chama de irrealidades alternativas: "o que é potencialmente diminuído nesses sistemas são os "outros" que podem ser efetivamente ocultados pelas informações que a pessoa que usa o RA deseja" (WOOD, 2010).

Lemos entende isso como:

(...) a narrativa (a escolha dos pontos de vista, do que é ou não visto, da relação com o espaço circundante e com o tempo etc.) está no cerne desses sistemas. Wood mostra que a construção de uma narrativa por sistema de RA pode, em um futuro próximo, estabelecer novos regimes de visão sobre o mundo que mostre e institua uma realidade mais palatável, mais confortável, menos tensa e complexa, reduzindo o real àquilo que pode ser tolerável. Trata-se de formas narrativas e regimes de visão que constroem um mundo "reduzido" a partir de um sujeito que tudo filtra pela lente da câmera do celular e dos dados lançados pelos softwares utilizados no sistema. (LEMOS, 2013, p. 11) 
Podemos entender que o processo de realidade aumentada é uma forma de ciberflânerie, é um espaço virtual e real concomitante permeável por marcas, no qual há uma sinergia entre o usuário e a dispositivo utilizado.

Nesse sentido, o usuário torna aquela experiência pessoal com suas próprias marcas, haja vista que cada usuário vai realizar uma decisão diferente diante do que a plataforma oferece, criando múltiplas possibilidades e a não linearidade, "o andar do flâneur é assim ato de tomar posse, de marcar simbolicamente o "meu" espaço" (LEMOS, 2001, p.8) e isso também é aplicável para o ciberespaço.

Nas instituições a experiência museológica também já foi modificada pela interferência tecnológica, como por exemplo, o Museu do amanhã ${ }^{7}$, localizado na cidade Rio de Janeiro e que se entende como um museu de ciências diferente, de acordo com a definição no site oficial é um ambiente de ideias, exploração e questionamento sobre a época em que vivemos e os caminhos que se abrem para o futuro. Possuem um aplicativo que permite realizar uma visita inteiramente com realidade aumentada a partir de um mapa interativo que facilita a exploração espacial e fornece os textos informativos sobre as atrações.

A tendência é realizar ainda mais exposições interativas e imersivas nos museus, uma vez que as tecnologias de realidade aumentada e realidade virtual estão mais baratas e mais possíveis de serem criadas, como nos indica Pardes,

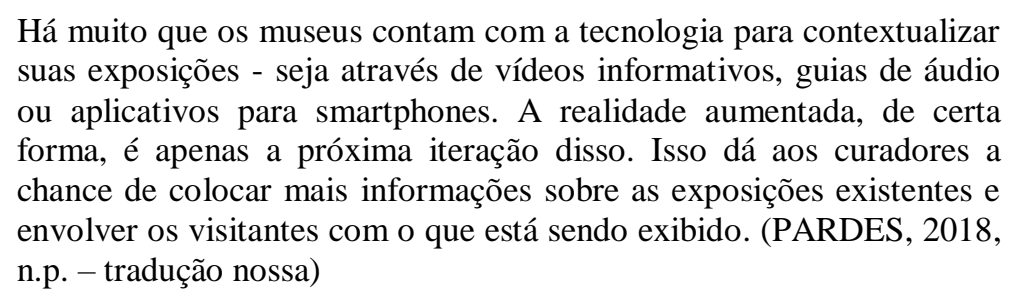

Outro caso foi a parceria realizada entre o Google Arts \& Cultura e o museu holandês Mauritshuis que criaram a Pocket Gallery em 2018 que posiciona juntos pela primeira vez na história, os 36 quadros do artista holandês Johannes Vermeer. Propõem uma experiência imersiva que permite explorar com elevado nível de detalhe as pinturas do artista, além de fornecer narrativas sobre a arte, a vida e o legado de Vermeer.

Em 2018, dentro do projeto Mural Arts Philadelphia, que se trata de um dos maiores programas de arte dos Estados Unidos relativamente à criação de murais em

\footnotetext{
${ }^{7}$ Disponível em: https://museudoamanha.org.br/pt-br. Acesso em 30 de maio de 2019.
} 
espaços públicos que intentam alterar a lógica da cidade e da vida dos cidadãos, realizaram o mural de grafite nomeado "Dreams, Diaspora, and Destiny", com dimensões monumentais ao ar livre e absolutamente interativo, uma vez que os espectadores apontavam os aparelhos smartphones para partes do mural e uma série de hologramas e músicas surgiam, seu acesso era via um aplicativo chamado MuralArtsAR disponível apenas para aparelhos da Apple.

Essa iniciativa concretiza a hibridização das realidades, propondo uma outra camada de mediação com as artes visuais em que há uma primeira relação visual com o mural, bidimensional, e uma outra derivada com a utilização do aplicativo que permite uma interação que depende da decisão e orientação de quem está utilizando, tridimensional, conforme percebe-se abaixo nos registros.

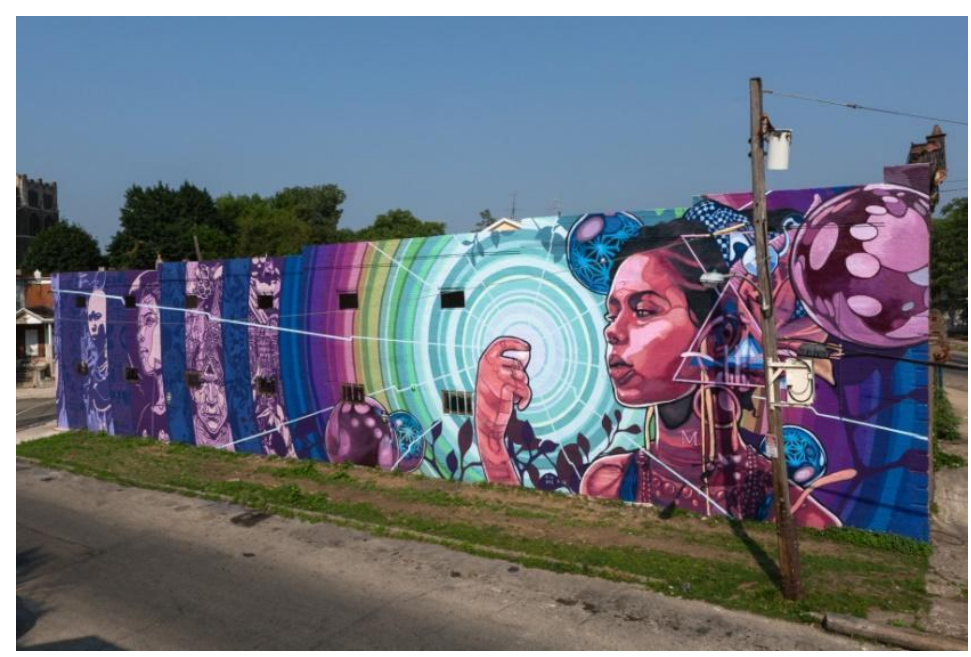

Figura 7: Mural Dreams, Diaspora, and Destiny (2018) 


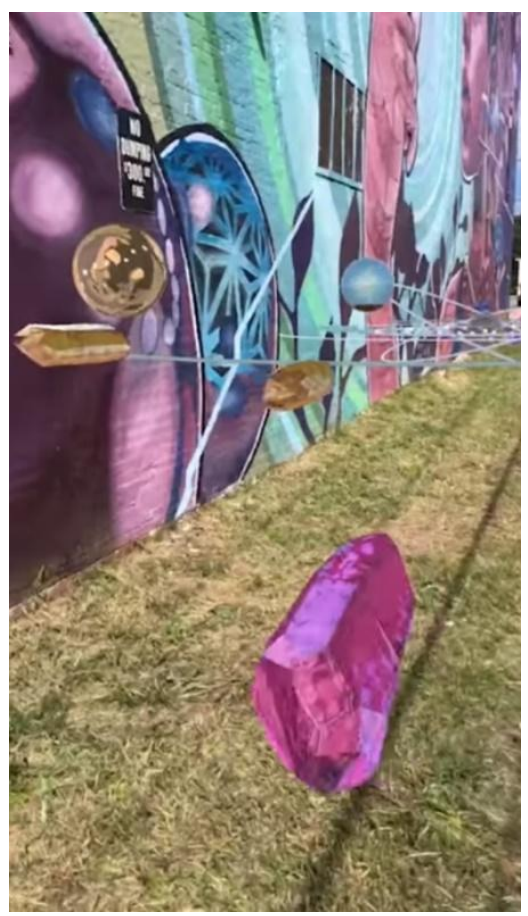

Figura 8: registro de elementos em realidade aumentada derivados do mural

A partir dessa colocação nas artes visuais é importante entender um pouco de como a realidade aumentada funciona relativamente à percepção visual.

\section{4) $O$ constructo da percepção visual}

Bourriaud (2009) propõe que a arte é uma forma de uso do mundo, uma negociação infinita entre vários pontos de vista:

Cabe a nós, espectadores, revelar essas relações. Cabe a nós julgar as obras de arte em função das relações que elas criam dentro do contexto específico em que se debatem. Pois a arte - e afinal não vejo outra definição que englobe todas as demais - é uma atividade que consiste em produzir relações com o mundo, em materializar de uma ou outra forma suas relações com o tempo e o espaço. (BOURRIAUD, 2009, p. 110)

Assim, é possível relacionar com a realidade aumentada, haja vista que se trata de uma linguagem que une estética, o tempo e o espaço e que cria uma série de relações até então inéditas para a sociedade, questionamentos entre os limites entre o real e o virtual. Assim como as tecnologias alteram a conjuntura social, também influencia a noção estética e a percepção visual dos sujeitos em sua relação com o mundo. 
Essa multiplicidade sensorial trazida pelo uso constante dos diversos meios e linguagens tecnológicas nos convoca para novas realidades de ordem perceptiva e inevitavelmente sobre questionamentos que são derivados disso. Crary (2012) entende a visão como um constructo histórico, no sentido de que aborda a relação da visão e do observador, marcada por uma grande ruptura na visualidade situada na modernidade, no final do século XIX e começo do XX, em que:

No início do século XIX, a ruptura com os modelos clássicos de visão foi muito mais do que uma simples mudança na aparência das imagens e das obras de arte, ou nas convenções de representação. Ao contrário, ela foi inseparável de uma vasta reorganização do conhecimento e das praticas sociais que, de inúmeras maneiras, modificaram as capacidades produtivas, cognitivas e desejantes do sujeito humano. (CRARY, 2012, p. 13)

Busca realizar uma análise da história da visão que não dependa apenas da exposição das mudanças nas práticas de representação, geralmente associadas à história da arte, Crary quer entender o papel do observador no campo em que sua visão se materializa: “a visão e seus efeitos são inseparáveis das possibilidades de um sujeito observador, que é a um só tempo produto histórico e lugar de certas práticas, técnicas, instituições e procedimentos de subjetivação" (CRARY, 2012, p. 15).

Nesse sentido essa interpretação histórica é bastante coerente quando pensamos no aumento da visualidade a partir da tecnologia, uma vez que quem a utiliza está sujeito a esse efeito do tempo presente.

Crary parte do princípio de que a visão, as técnicas e os discursos ao redor dela foram periodizados historicamente e mostra que há uma tradição escópica da visão que foi cristalizada e em parte tem sido efetiva, mas ele insiste em questionar que existem descontinuidades importantíssimas de algumas construções hegemônicas.

Discute, por exemplo, a câmara escura, propondo que não é apenas um objeto neutro e inerte ou um equipamento com uma série de premissas técnicas. Em vez disso, foi incorporado em uma organização muito mais larga e densa do conhecimento e do sujeito observador. Foi um modelo de como a observação leva a verdadeiras interferências sobre o mundo exterior, um assunto central na epistemologia 
inseparavelmente ligada aos discursos filosóficos da época como de Descartes e Locke. Ou seja, em como um dispositivo altera toda uma lógica.

Pode-se chamar de revolução dos meios de percepção:

\begin{abstract}
Nos últimos cem anos, as modalidades perceptivas têm se encontrado - e assim continuam - num estado constante de transformação, ou, como diriam alguns, num estado de crise. Se é possível dizer que a visão teve alguma característica constante ao longo do século XX, esta seria precisamente a falta de características constantes. Ao contrário, a visão está imersa em um padrão de adaptabilidade a novas relações tecnológicas, configurações sociais e imperativos econômicos. Aquilo que, por exemplo, costumamos chamar de cinema, fotografia e televisão, são elementos transitórios em uma sequência acelerada de deslocamentos e obsolescências que são parte das operações delirantes da modernização. (CRARY, 2013, p. 35)
\end{abstract}

Relacionando com McLuhan, reitera-se mais uma vez a potência da utilização das tecnologias, haja vista que essas extensões são integrantes da vida humana e influenciam, tal como afirma Crary, a forma da percepção nesse estado constante de transformação.

Essa perspectiva também é compartilhada por Nochlin (1994), que entende que a retórica visual da modernidade se fundou na metáfora da fragmentação, na mutilação e na destruição vinda da sociedade. De forma que a onipresença do fragmento, em sua grande variedade de formas, vem de uma representação visual da revolução francesa, do imaginário das decapitações e em como foi proposto destruir uma civilização para se criar uma nova (NOCHLIN, 1994, p. 10 - tradução nossa). A autora entende que a visualidade da modernidade foi marcada por corpos em pedaços e proveniente da crítica de arte, analisa fotografias, pinturas e esculturas que corroboram para essa visão. O que é bastante interessante se trata da relação entre a iconografia e acontecimentos políticos e sociais e trazendo para o objeto dessa pesquisa, adicionar a questão da tecnologia.

Essa presença do fragmento ainda se mantém se pensarmos no uso das redes, por exemplo, conteúdos curtos e muito editados de fácil absorção reiterando assim a forma como somos condicionados a receber partes e pedaços.

Assim, mostra-se necessário estabelecer uma relação entre o observadorespectador e sua visão com a tecnologia. Para Crary, quando a visão se realocou na subjetividade do espectador, dois caminhos se abriram: um que levou a múltiplas afirmações de soberania e autonomia da visão e outro que levou a normatização e 
regulação crescente do observador, que vem do conhecimento do corpo visionário (CRARY, 2012, p. 147).

Ao mapear a história da visão, o autor entende que o discurso acerca da visualidade nos séculos XVII e XVIII reprimiu e ocultou o que ameaçava a transparência do sistema óptico e Goethe, com a teoria das cores, sinalizou que ocorre uma inversão, propondo a opacidade do observador como condição necessária para o aparecimento dos fenômenos.

Com Schopenhauer (apud CRARY, 2012, p. 78), o observador toma outro caminho, deixa de ser receptor passivo de sensações e o coloca como um sujeito "que era a um só tempo o lugar e o produtor de sensações", antecipa, portanto a percepção artística autônoma (CRARY, 2012, p. 78), assim, "a visão subjetiva afirmada por Goethe e Schopenhauer, que dotava o observador de uma nova autonomia perceptiva, coincidiu também com a transformação do observador em um sujeito de novos saberes e de novas técnicas de poder" (CRARY, 2012, p. 82).

Fica bastante evidente que:

\begin{abstract}
A reconstrução do campo visual não foi feita como tábula rasa, sobre a qual representações ordenadas podiam ser dispostas, mas como uma superfície de inscrição em que uma gama aleatória e indiscriminada de efeitos podia ser produzida. A cultura visual da modernidade viria a coincidir com essas técnicas do observador. (CRARY, 2012, p. 97)
\end{abstract}

Pensando na formação de imagens, em meados da década de 1820 surgiram os primeiros aparelhos ópticos como o taumatrópio, que consistia em um pequeno disco com imagens impressas dos dois lados e fios que permitiam que o objeto fosse rodopiado com o movimento das mãos.

Sua importância para a visualidade dá-se pela ilusão projetada, por exemplo, como na imagem abaixo, em que de um lado havia um desenho de um pássaro e do outro uma gaiola e que ao ser rodopiado, transformava a imagem em um pássaro dentro da gaiola, sendo esse um primeiro objeto muito importante, haja vista que: "a simplicidade desse "brinquedo filosófico" tornou inequivocamente clara a natureza a um só tempo fabricada e alucinatória de sua imagem e a ruptura entre a percepção e seu objeto" (CRARY, 2012, p. 107). Abaixo um exemplo do movimento realizado por um taumatrópio: 


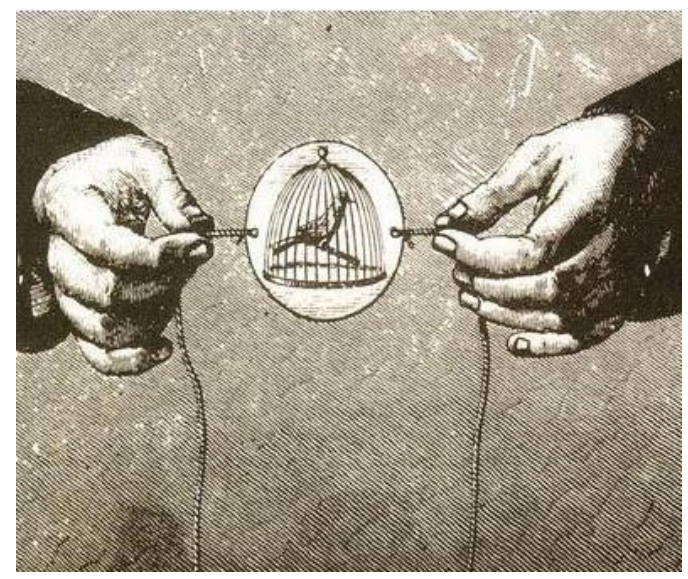

Figura 9: exemplo de taumatrópio

Relacionando com a percepção desses objetos, Laurentiz (2017) entende que o homem tem capacidade para elaborar signos que são retroalimentados pelo ambiente que impõem sistemas cada vez mais complexos de interpretações, "e entendemos sistemas complexos de interpretações tanto modelos representacionais quanto mediações tecnológicas, no sentido de serem interfaces de percepção, logo, também capazes de gerar signos" (LAURENTIZ, 2017, p. 3698).

Sobre a imagem mental, entende que é uma representação interna que funciona como uma forma fraca de percepção, "um modelo formado por objetos (coisas objetivadas) pode causar efeitos sensoriais também, mesmo que em menor potência, da mesma forma que coisas do mundo nos tocam" (LAURENTIZ, 2017, p. 3614). Bastante importante é como funciona esse sistema que se retroalimenta, uma vez que um novo meio é capaz de causar efeitos nas interfaces, que irão afetar as representações internas e causarão novas interferências nas percepções:

Sobre a interferência entre imagens mentais e imagens de coisas percebidas (objetivadas), o pensamento conformado afeta processos perceptivos no momento que ele conforma, informa e forma. Um simulador age desta maneira, e por reflexividade sensorial interferirá na própria ação simulada. Além disso, o pensamento conformado possui portabilidade, e com isso a possibilidade de compartilhamento em diferentes plataformas, o que significa dizer que pode ser articulado em outro meio e, consequentemente, a medialidade deste novo meio será capaz de causar efeitos nas interfaces, que afetarão as representações internas e, por sua vez, causarão novas interferências nas percepções, retroalimentando o sistema. (LAURENTIZ, 2017, p. 3614) 
Outro aparelho óptico importante foi o fenacistoscópio que utilizava da experiência da velocidade e o movimento da máquina para revelar imagens e: “corrobora a afirmação de Walter Benjamin de que, no século XIX, a tecnologia subjugou o sistema sensorial humano a uma modalidade complexa de treinamento" (CRARY, 2012, p. 112).

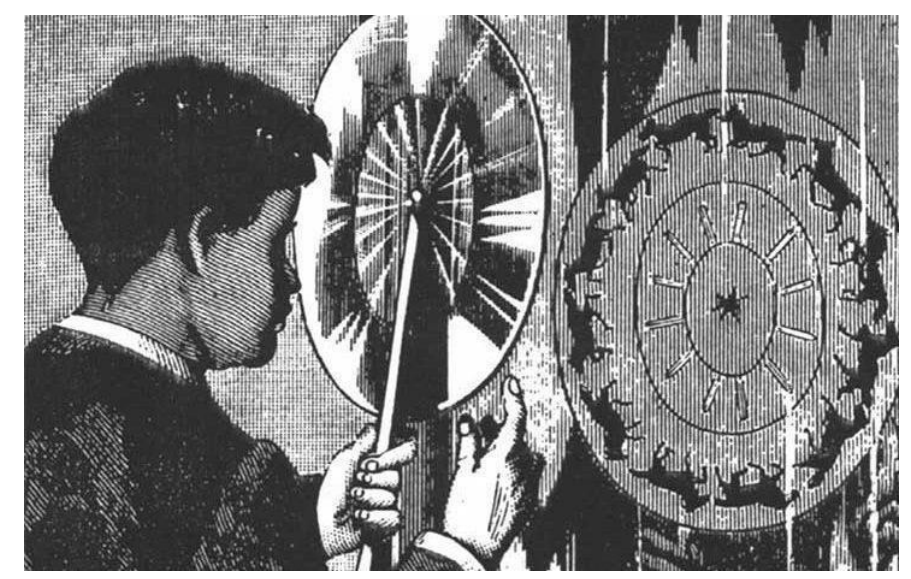

Figura 10: exemplo de fenacistoscópio

O que no caso do fenacistoscópio, com exemplo na imagem acima, é o mais inovador é em como colocava o sujeito como "um corpo individual que é a um só tempo um espectador; um sujeito da pesquisa empírica e da observação; e elementos de uma produção mecanizada" (CRARY, 2012, p. 112). Assim, fazia com que o observador se tornasse um componente essencial, do qual sem ele, não haveria nenhuma experiência. Apesar do lapso temporal de quase duzentos anos, podemos entender a potência do observador/ sujeito diante da linguagem da realidade aumentada da mesma forma, sem ele não há ativação e, portanto, não existe a experiência, dotando ao observador/sujeito uma nova autonomia perceptiva, da potência de ser um ativador.

O questionamento do tempo é recorrente na literatura dessa pesquisa, primeiro pela velocidade do desenvolvimento da linguagem que a cada momento se renova e propõe novas formas de utilização, e segundo, pois reflete um fator do contexto do contemporâneo hiperconectado, tal como Crary argumenta a respeito do capitalismo no modelo 24/7.

Para Bondía (2002) dialogando com Crary, Turkle e Han, o sujeito contemporâneo está em constante insatisfação, quer estar permanentemente excitado e 
não consegue mais lidar com o silêncio, está em formação permanente e acelerada, de constante atualização, sendo que:

\begin{abstract}
Nós somos sujeitos ultra informados, transbordantes de opiniões e superestimulados, mas também sujeitos cheios de vontade e hiperativos. E por isso, porque sempre estamos querendo o que não é, porque estamos sempre em atividade, porque estamos sempre mobilizados, não podemos parar. E, por não podermos parar, nada nos acontece. (BONDÍA, 2002, p. 24)
\end{abstract}

Isto posto, existe então o sujeito da experiência, esse que pode ser afetado, que se torna um ponto de chegada, um lugar a que chegam as coisas, é: "sobretudo um espaço onde têm lugar os acontecimentos" (BONDÍA, 2002, p. 24), é um sujeito exposto, que existe, que é fascinante, no qual a "experiência é a passagem da existência, a passagem de um ser que não tem essência ou razão ou fundamento, mas que simplesmente 'ex-iste' de uma forma sempre singular, finita, imanente, contingente" (BONDÍA, 2002, p. 24).

Trata-se de um sujeito receptivo, interpelado e submetido, aberto à própria transformação e é um território de passagem. Um acontecimento pode ser comum a mais de um sujeito, mas a experiência é singular em cada ser, de maneira que é impossível de ser repetida. Realmente a experiência diante dos dispositivos é pessoalizada a cada sujeito que a utiliza, especialmente no caso dos jovens que já não estabelecem barreiras, estando absolutamente intrínsecos na hibridização.

Basbaum (2006) retoma o trabalho do filósofo Merleau-Ponty que coloca a percepção como ênfase decisiva na experiência vivida e em como os sujeitos estão ligados ao mundo por laços perceptivos, que assim são "possibilidades interessantes para pensarmos a nossa experiência contemporânea nas sociedades tecnológicas - e, assim, os desafios que se colocam para a arte contemporânea” (BASBAUM, 2005, p. $1)$.

Portanto, a realidade não seria então um mundo pré-existente e objetivo, mas um "acordo aberto e sempre inacabado entre as múltiplas subjetividades que partilham este mesmo real, gerando um "cosmos" senso-comum que assumimos como sendo o mundo real" (BASBAUM, 2005, p. 2). 
A percepção visual oferece um amplo conjunto de relações dinâmicas, imersas de sentido e isso se relaciona com o que $\mathrm{Li}$ et al (2018) afirma sobre as imagens, essas não são apenas um conjunto aleatório de objetos, cada uma delas representa uma rede de relacionamentos interconectados, que carregam significados semânticos e ajudam o espectador a diferenciar as instâncias das entidades.

A relação imagética vem a partir da visão, assim:

\begin{abstract}
Os seres humanos demonstram níveis de entendimento visual que vão muito além das formulações atuais das tarefas principais de visão (por exemplo, detecção de objetos, reconhecimento de cenas, segmentação de imagens). Um elemento chave da inteligência visual é a capacidade de interagir com o ambiente e planejar uma sequência de ações para atingir objetivos específicos; (LI et al, 2017, p. 1 - tradução nossa)
\end{abstract}

Uma semântica visual é a base para as relações entre os atores humanos e não humanos e a interação se mostrou como um eixo importante em que: "a sinergia entre percepção e interação atraiu um interesse crescente na comunidade da visualidade e robótica. Trabalhos recentes possibilitaram um aprendizado mais rápido e produziram mais representações visuais robustas através da interação" (LI et al, 2017, p. 1 tradução nossa).

Lanier entende que a visão depende constantemente da sua continua experimentação realizada pelo sistema nervoso, atualizando em grande parte pelo movimento da cabeça e dos olhos. Funciona "por procurar e notar mudanças ao invés de constâncias, a expectativa neural existe do que vai ser visto ainda. O sistema nervoso age como uma comunidade científica, vorazmente curiosa e constantemente testando ideias" (LANIER, 2017, p. 53 - tradução nossa).

Portanto, não é possível desvencilhar o sujeito contemporâneo hiperconectado da forma como sua visão tem sido subjetivada pelo uso ininterrupto da tecnologia, em como a utilização da realidade aumentada altera de forma substancial sua percepção de mundo. Afirma que: "como a tecnologia altera tudo, nós temos que ter a chance de descobrir empurrando a tecnologia o mais longe possível para que possamos redescobrir algo em nós mesmos que transcenda a tecnologia" (LANIER, 2017, p. 55 - tradução nossa). 
A visão inspirou particularmente a consciência da contemplação no último século e para Lanier, "talvez demore muitas gerações antes que todos internalizem o quanto a dominância visual se tornou a era da informação" (LANIER, 2017, p. 127 tradução nossa).

Fica evidente que nossos sentidos perceptivos são permeados pelas conexões tecnológicas, mas podemos questionar qual visão temos desse mundo mediado pelos dados, sempre permeada por algum dispositivo:

\begin{abstract}
A relação entre nossos sentidos perceptivos e os métodos técnicos de amostragem da realidade material em códigos digitais nos permite acessar em tempo real seus dados constitutivos. Devemos aprender a ver o mundo, pois o mundo é o que vemos; mas qual visão temos dele por meio dos dados? Percebemos que, na formação da imagem, o difuso é a transição para o visível, que ostenta o futuro da imagem, renovando-a no tempo real da transmissão. (VENTURELLI; MELO, 2019, p. 203)
\end{abstract}

Lembrando que existem algumas diferenças gritantes entre a visualidade da realidade aumentada e da realidade virtual, isso porque a segunda demanda imersão e isolamento do mundo real e a aumentada propõe a mescla.

Nessa trajetória da visão e da interferência tecnologia, há um marcador temporal importante, em março do ano 2018, a empresa Google lançou a primeira edição do ARCore, um kit de desenvolvimento de aplicativos em realidade aumentada.

E de acordo com a descrição do programa, a intenção é prover um site que apresenta trabalho de codificadores que estão experimentando a realidade aumentada, utilizando o ARCore criado para o sistema operacional Android. Assim, no site do programa é possível acompanhar alguns desses projetos desenvolvidos de forma a inspirar mais codificadores a imaginar o que poderia ser feito com realidade aumentada.

Uma das maiores preocupações dos desenvolvedores é a clara divisão entre o que é real e o que é virtual, portanto, o que o ARCore propõe é um ambiente mais profundo, em que as barreiras estejam mais mescladas e menos evidentes, intenta-se portanto dar a sensação de que esses objetos existem no mundo real, como por exemplo, com a inserção de um tigre digital em um ambiente urbano. 


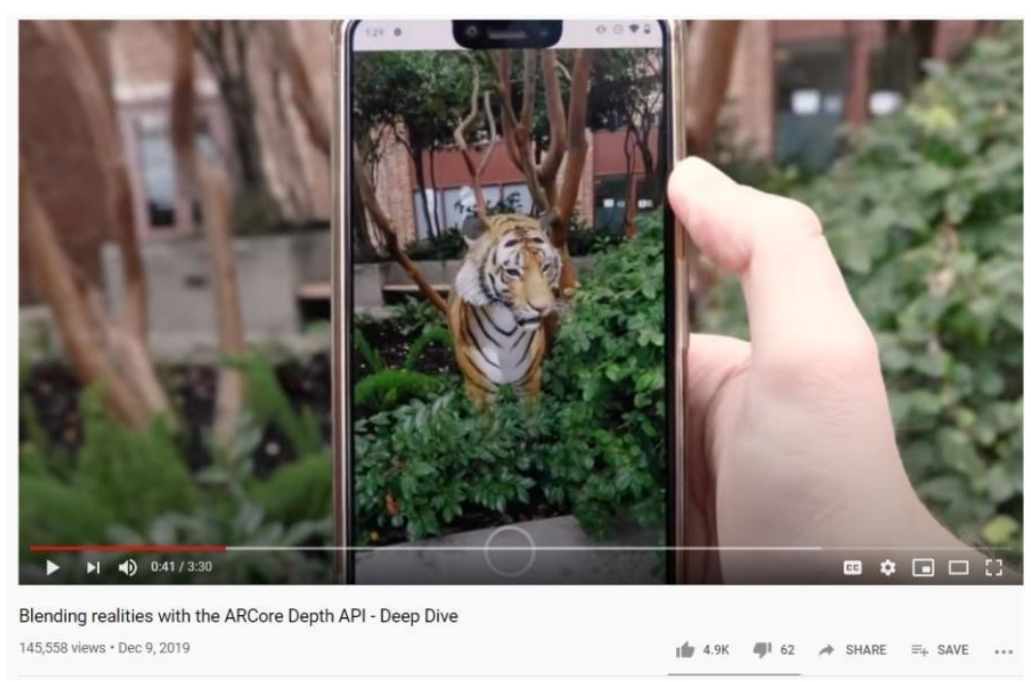

Figura 11: Frame do vídeo sobre o lançamento do programa ARCore Depth API Deep Dive ${ }^{8}$

Os recursos principais utilizados para realizar essa mescla são:

O ARCore usa três recursos principais para integrar conteúdo virtual ao mundo real, como pode ser visto através da câmera do seu telefone: o rastreamento de movimento permite que o telefone entenda e rastreie sua posição em relação ao mundo. A compreensão ambiental permite que o telefone detecte o tamanho e a localização de todos os tipos de superfícies: superfícies horizontais, verticais e angulares, como o chão, uma mesa de café ou paredes. A estimativa de luz permite ao telefone estimar as condições de iluminação atuais do ambiente. ${ }^{9}$ (2020 - tradução nossa)

Assim, a tecnologia se apoia no movimento que o ARCore usa da câmera do telefone para identificar os arredores, determinando a posição e a orientação enquanto ele se move pelo espaço, "a compreensão do mundo real pela ARCore permite que você coloque objetos, anotações ou outras informações de uma maneira que se integre perfeitamente ao mundo real" (site ARCore, 2020, n.p. - tradução nossa).

Jackson questiona se essa nova experiência estética é um escape da realidade ou uma realidade preferível e conclui, portanto, que se trata de uma alteração estética positiva que requer o encontro mais do que a perda do sujeito, "e permanecendo conectado com o tempo e o espaço atuais para fundamentar o que você está experienciando na ecologia dinâmica daquele contexto" (JACKSON, 2001, p. 351 tradução nossa). Parece-nos uma perceptiva um pouco romantizada acerca da ecologia

\footnotetext{
${ }^{8}$ Disponível em: https://www.youtube.com/watch?v=VOVhCTb-1io. Acesso em 27 de março de 2020.

${ }^{9}$ Disponível em: https://developers.google.com/ar/discover. Acesso em 28 de março de 2020.
} 
que envolve a experiência do sujeito, especialmente retomando Turkle e a figura dos hikikomori que se perdem completamente.

Analisando a visualidade contemporânea e a visão como constructo histórico é importante recuperar a discussão célebre a respeito da aura por Benjamin, o qual se tratava de um período específico da estética, que relacionava a unicidade dos objetos e com a representação no espaço, questão vinda do renascimento sobre as regras da perspectiva.

Rush (2005) reflete sobre a reprodução das imagens na contemporaneidade e a preocupação levantada por Benjamin sobre o objeto artístico nos anos 1930, confrontando com a utilização da tecnologia digital:

\begin{abstract}
A questão da "reprodução" das imagens via câmeras em movimento ou paradas tem muito pouco a ver com a radicalidade das novas capacidades de criação de trabalho que não se referem ao mundo não digital; de fato, isso não se refere ao mundo tridimensional como conhecêssemos. "Reprodução" é para o mundo digital o que o balão de ar quente foi para a aviação. Usar a tecnologia digital é agora uma forma de introduzir novas maneiras de produção e não reprodução. (RUSH, 2005, p. 180- tradução nossa)
\end{abstract}

$\mathrm{Na}$ estética digital o panorama é absolutamente diferente, a tecnologia digital traz para a imagem uma maleabilidade, entendendo que a imagem anteriormente era estática, "a imagem se torna informação no computador, e toda informação pode ser manipulada" (RUSH, 2005, p. 181 - tradução nossa). Assim, pela primeira vez na história da visualidade, a imagem é um sistema dinâmico.

As imagens acabam sendo domesticadas e se tornam consumíveis, sendo que essas, como reproduções, apresentam uma realidade otimizada, aniquilam justamente o valor icônico original da imagem (HAN, 2018, p.54).

Um exemplo que permite visualizar essa mescla da informação e manipulação da imagem é o aplicativo normanAR, criado por Jonas Jongejan e Irene Alvarado que utilizou o ARCore como parte de um experimento colaborativo entre James Paterson e o Google Creative Lab.

Consiste em fazer animações de desenho e as adicionar ao mundo real, ao percorrer os ambientes, o usuário toca em pontos estipulados pelo aplicativo e uma 
variedade de animações aparecem, podendo caminhar para poder enxergar de diferentes ângulos.

Assim, é perceptível que quem maneja o smartphone é que estabelece essa relação com as animações de desenho, sendo específicas para cada movimento escolhido e também para cada ponto de vista, se de cima, de lado ou por baixo, como no frame abaixo.

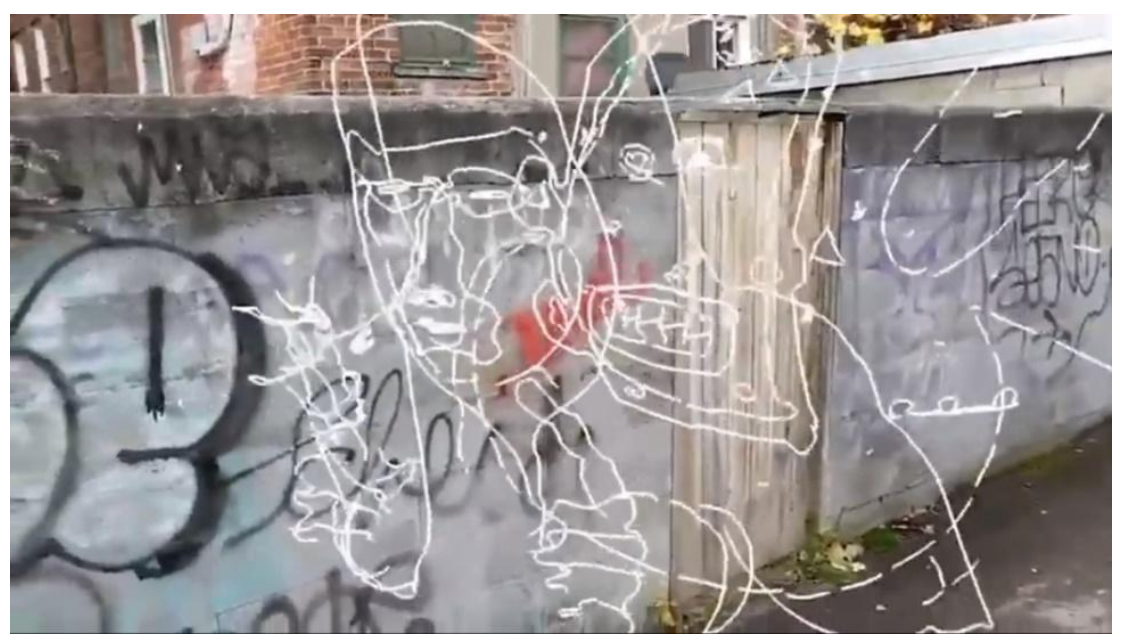

Figura 12: Frame do vídeo no YouTube sobre o normanAR ${ }^{10}$

Um aspecto que foi levantado por Manovich (2007) é a cultura do remix e em como a informação é estética, afirmando que:

Hoje é verdade que muitas das nossas áreas culturais e de estilo de vida - música, moda, design, arte, aplicações web, mídia criada pelo usuário, comida - são governadas por remixes, fusões, colagens, ou mash-ups. Se o pós-modernismo definiu os anos 80, o remix definitivamente domina os anos 2000, e provavelmente continuará a governar a próxima década também (MANOVICH, 2007, p. 1 tradução nossa)

O texto de Manovich, datado de 2007, já levantava muitas questões focando principalmente na questão do remix, entendendo a questão da remixagem como uma mistura que originalmente tinha um significado preciso e estreito que gradualmente tornou-se difuso. Porém, ainda não antecipava a complexidade da cultura do samplear

\footnotetext{
${ }^{10}$ Disponível https://www.youtube.com/watch?time_continue $=13 \& v=6 x T G r R a L 66 U \&$ feature=emb_title Acesso em 21 de nov. de 2019.
} 
de pouco mais de dez anos depois, especialmente com o surgimento do Instagram que proliferou ainda mais a imagem como informação.

Outro aspecto relevante levantado pelo autor é a questão da apropriação, estratégia essa que como nunca antes alcançou proporções tão amplas de sua utilização como na contemporaneidade e propõe a utilização do termo remixagem, haja vista que para ele, apropriação não deixa o contexto original do mundo da arte onde foi cunhado, e remixar sugere uma reformulação sistemática de uma fonte.

Manovich (2017) reflete sobre os novos meios e atualiza sua própria conceituação:

\begin{abstract}
E agora? Pesquisa visual e recomendações no Google, Yandex, YouTube, Instagram ou Pinterest nos expõe a infinitas imagens e vídeos, enquanto sites de grandes museus, convidam nós para navegar centenas de milhares de obras de arte digitalizadas e artefatos históricos. Um visual "mensagem" ou um "sinal" (para usar termos semióticos) é agora nunca é isolamento, mas em vez disso é uma parte das grandes séries que experimentamos como infinitas. (MANOVICH, 2017, p. 3 - tradução nossa)
\end{abstract}

Sugere assim a chamada Big cultural visual data, que se trata de criar métodos e ferramentas que permitam ver o Big Data em primeiro lugar, não tentando analisá-lo ou substitui-lo com modelos estatísticos ou redes neurais e sim, pensar sobre os meios hoje, o que pode ser laborioso, considerando a enorme quantidade de imagens compartilhadas diariamente.

Um exemplo que se utiliza exatamente da remixagem e da apropriação é o aplicativo Drawalong AR, lançado em abril de 2019 em colaboração com Amanda Rach Lee, que trabalha com tutoriais de desenho e caligrafia. $\mathrm{O}$ aplicativo intenta transpor os tutoriais a partir da realidade aumentada para o papel, de forma a minimizar a frustração do usuário de olhar para a tela e o papel e não corresponder à sua expectativa. Assim, funciona sobrepondo os vídeos sobre o bloco de desenho, a câmera simula, portanto, a função realizada por um papel vegetal. Utiliza-se da lógica do espelho simulando o desenho a partir do aplicativo transpondo na realidade física que se torna a realidade digital, uma vez que é pelo movimento do usuário que o desenho ou a escrita toma forma e sai do smartphone, como no registro abaixo. 


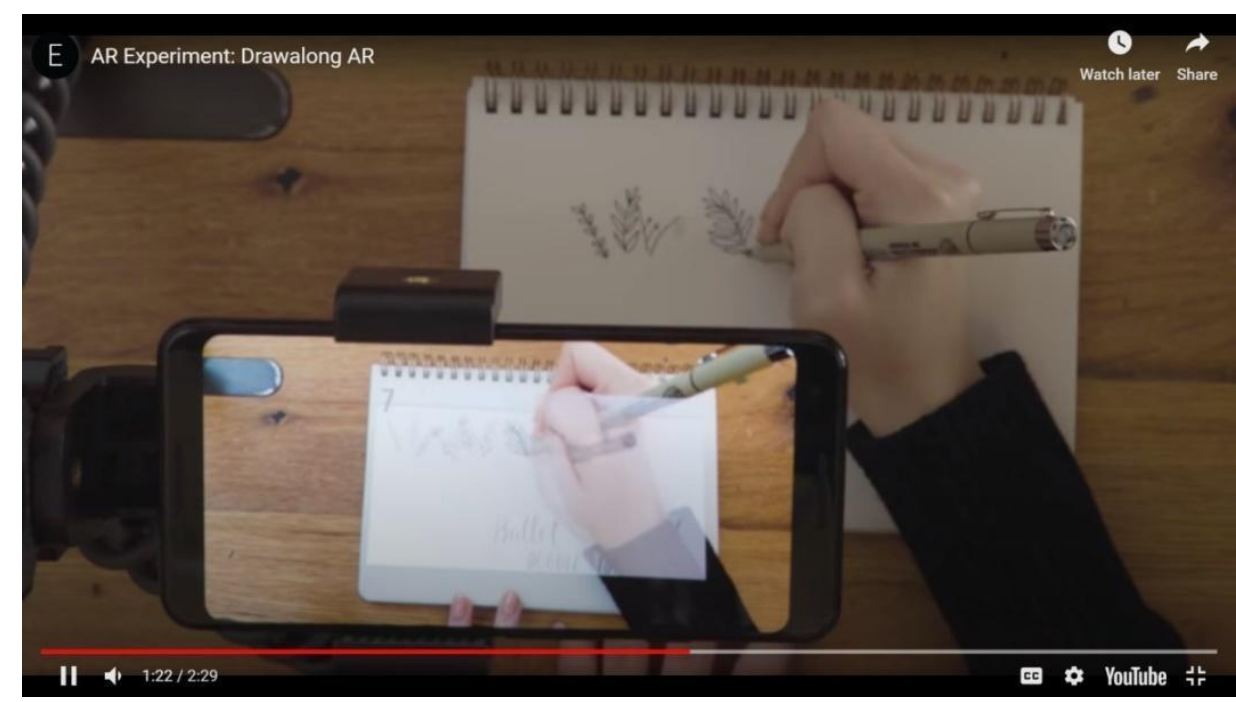

Figura 13: Frame do vídeo no YouTube sobre o DrawalongAR ${ }^{11}$

Mais acessível ainda é a própria busca do Google em realidade aumentada, lançada em 31 de março de 2020, em que ao inserir na busca há a opção View in 3D (veja em 3D). A ferramenta possibilita uma visão absolutamente espacial em 360 graus e ao conceder acesso permite que o objeto ou animal ou qualquer outra opção seja vista no ambiente real que o usuário está.

Ou seja, é uma estratégia bastante interessante poder ter uma perspectiva tridimensional de uma estrutura molecular, como no exemplo trazido aqui, em que se é possível ter uma visão mais dinâmica, mais profunda e mais interativa do que na página de um livro, além de relacionar com o espaço em que o sujeito está inserido. Abaixo um exemplo da busca em terceira dimensão do Google.

\footnotetext{
${ }^{11}$ Disponível https://www.youtube.com/watch?time_continue=88\&v=S9g1PqY19jE\&feature=emb_title Acesso em 25 de nov. de 2019.
} 


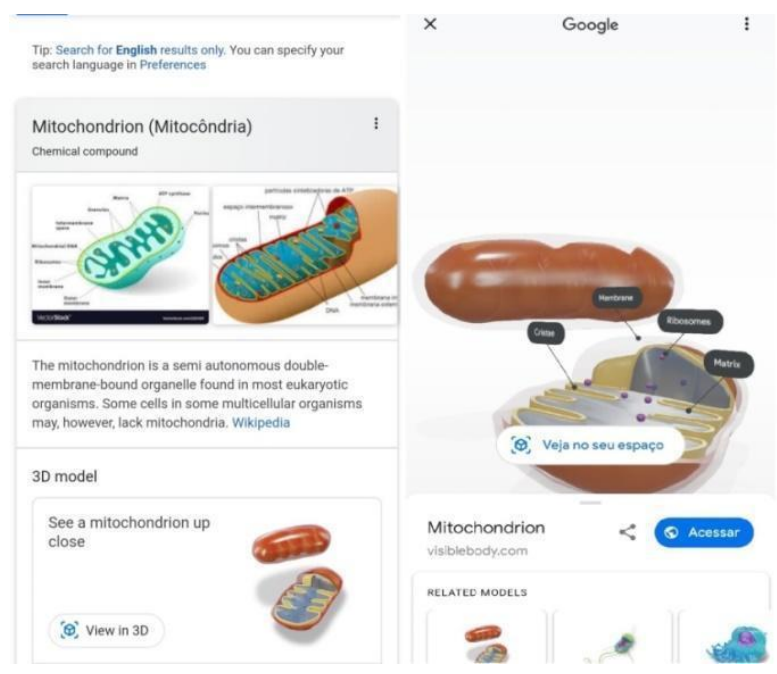

Figura 14: exemplo retirado da busca do Google

O que insere também um aspecto de entretenimento, de mesclar o virtual com o real e realizar vídeos e fotos. Para, além disso, há algumas buscas como elementos de biologia, que permitem um olhar tridimensional e aprofundado que podem facilitar o aprendizado no sentido de ter uma noção muito mais próxima da realidade do que uma foto impressa em um livro escolar em preto e branco. Ou seja, isso cria outra relação diante do objeto de estudo, uma outra camada de apreensão.

Ainda são opções limitadas do que se pode ver na busca aumentada, mas é provável que a longo prazo as opções aumentem.

\section{5) Usos nas redes sociais}

Novas literacias demandam a constante atualização dos conjuntos de habilidades e se mostra importante comentar sobre a influência do aspecto econômico no desenvolvimento e na pesquisa de novas tecnologias, enquanto as redes sociais têm popularizado o maior acesso e utilização da realidade aumentada.

Han (2018), ao utilizar o termo homo digitalis, entende que o sujeito digital se externa em busca de exposição e trabalha em sua otimização, competindo o tempo todo por atenção. Nesse sentido, as redes sociais vêm sendo uns âmbitos de estudo comportamentais de como os sujeitos se entendem e atuam nesses espaços virtuais.

Lanier (2018) apresenta em dez argumentos o quanto as redes sociais são nocivas e, por que os sujeitos devem sair delas, uma vez que estão todos "sendo 
hipnotizados pouco a pouco por técnicos que não podemos ver, para propósitos que não conhecemos. Agora somos todos animais de laboratório" (LANIER, 2018, p.13) e que é possível ter uma vida pública independente da vida online.

E entende que o principal processo das redes sociais a ganharem dinheiro, “embora também cause danos à sociedade, é a modificação de comportamento. Essa prática exige técnicas metódicas que mudam o padrão comportamental de animais e pessoas" (LANIER, 2018, p.17). Perissinotto entende que a chance de uma sociedade desconectada é bastante improvável então se pergunta como seríamos sujeitos com livre arbítrio na internet:

Se na década de 90 perguntávamos qual seria a importância da Internet, e a resposta que imaginávamos era a de que ela seria um espaço público inédito e inteiramente apto para distribuir informação livre e descentralizada, hoje a pergunta parece ser mais a seguinte: "Como nos manter livres na Internet?" A pergunta de Benedict Evans também vai nessa direção. Ela pode ser formulada nos seguintes termos: "Por que a criptografia importa tanto para a Internet, hoje?" (PERISSINOTTO, 2019, p. 13)

O que Lanier entende como um perigo é o quanto o vício é nocivo às pessoas, e perdem completamente seu livre arbítrio. É tão intenso que vão perdendo o contato com pessoas reais (como no caso extremo dos hikikomori) e "quando muitos estão viciados em esquemas manipuladores, o mundo fica obscuro e louco" (LANIER, 2018, p.17).

$\mathrm{O}$ autor relaciona à teoria behaviorista de receber uma recompensa e faz o sujeito repetir o ato, com a indústria das curtidas típica das redes sociais. Além disso, estimulam uma pressão social, mantida por um status social, competição e julgamento, esse último que Han (2018) chama de shitstorm ou tempestade de indignação.

Outra preocupação é proliferação de falsas informações com grande facilidade e também:

A velocidade, o idiotismo e o crescimento exponencial das falsas percepções sociais têm sido amplificados a ponto de as pessoas com frequência parecerem já não estar vivendo no mesmo mundo, o real. Esse é mais um daqueles problemas óbvios que se aproximaram de nós sorrateiramente. Não só o espaço público perdeu dimensão, mas as características em comum vêm diminuindo no geral. (LANIER, 2018, p.78) 
O que Lanier propõe é o pagamento das redes sociais pelos usuários, não por terceiros que são ocultos, de forma que se quiserem pagar para verem anúncios vai da escolha de cada um. O autor é um atuante no movimento de contra cultura e de reflexão sobre o quanto a tecnologia altera nossa cultura:

\footnotetext{
O incentivo para envenenar o mundo será desfeito. Só terei uma conta no Facebook, no Google ou no Twitter quando puder pagar por isso — e, de maneira inequívoca, ter e determinar o preço pelo uso de meus dados, e também for fácil e normal ganhar dinheiro se meus dados forem valiosos. Pode ser que eu tenha que esperar um pouco, mas valerá a pena. (LANIER, 2018, p.107)
}

Andy Warhol foi uma figura icônica no campo das artes e disse que "no futuro, todos terão seus quinze minutos de fama", de certa forma previu o que estava por vir mais de quarenta anos depois com as intensas tentativas das pessoas se destacarem nas redes sociais, há uma intensificação da cultura da celebridade. De forma que para Han (2018) a contemporaneidade "domina uma falta total de distância, na qual a intimidade é exposta publicamente e o privado se torna público" (HAN, 2018, p. 12). Nesse sentido, as redes sociais se mostram como espaços de exposição do privado, "a mídia digital como tal privatiza a comunicação, ao deslocar a produção de informação do público para o privado" (HAN, 2018, p. 13).

Isso se adequa à crítica de Lanier e, portanto, até que tenhamos mais livre arbítrio sobre as redes, caso isso venha a acontecer, ainda teremos que analisar os impactos comportamentais na vida dos sujeitos/usuários.

As redes sociais permitem análises das mais variadas, tanto comportamentais, de produção de conteúdo, do movimento de shitstorms, das fake news, da remixagem, enfim, são muitas possibilidades. No entanto, ainda pensando na visualidade gostaríamos de evidenciar o quanto tem sido importante nos quesitos aceitação e disseminação da linguagem realidade aumentada a partir do uso dos filtros nas redes sociais, especialmente nos casos específicos do Instagram e do TikTok.

\subsection{1) Realidade aumentada no Instagram e no TikTok}

No quesito disseminação, há uma enorme abrangência do Facebook e do Instagram, rede que foi adquirida pelo grupo Facebook em 2012 e que era inicialmente direcionada para fotografias. No entanto, o Instagram foi se transformando em uma rede 
diversa que investe em constante renovação. O que era um compartilhamento de fotos foi se desenvolvendo para outras funções, tais como exibir vídeos, realizar chamadas de vídeo, ter conexão com outros aplicativos - como o próprio Facebook - para compartilhamento do mesmo conteúdo, compartilhamento com o Spotify e o que tem sido um grande investimento de atualização, os Stories.

O Instagram Stories foi lançado em uma estrutura similar a outro aplicativo, o Snapchat. Baseia-se em compartilhamento de conteúdo que ficam disponíveis por apenas 24 horas. A proposta é de algo temporário com muitas postagens com a intervenção do usuário, haja vista que é possível colocar figurinhas, fazer colagens, inserir frases, músicas, desenhos e os filtros criados por usuários em realidade aumentada.

Em 2018, o Facebook elaborou uma plataforma para Windows e Apple, chamada Spark $A R^{12}$, que permite aos usuários a criação de filtros e efeitos em realidade aumentada. O convite à participação e empoderamento dos usuários, no sentido de poderem realizar seus próprios filtros, vem em uma estrutura baseada em tutoriais, com guia de execução, um roteiro a ser cumprido.

Quando o usuário faz seu filtro, pode divulgá-lo na rede social e outros usuários podem com apenas um clique, salvar o filtro e continuar, portanto, a distribuí-lo de forma gratuita. Lembrando novamente que afirmar ser sem custo é ilusório, especialmente considerando a teoria de Morozov e a Big Tech e em como os dados são o pagamento. É inegável a ampla disseminação da utilização da realidade aumentada no cotidiano diário das pessoas que podem até não saber nomear os filtros como realidade aumentada mas são isso que estão utilizando.

Dentro do programa há opções para criação de filtros a partir de samples já existentes ou a criação de um efeito do zero, com abas de ações para efeitos e materiais usados para criá-los e abas de manipulação e edição de elementos do filtro. Cada filtro determina um disparador que será o diferencial, por exemplo, alguns solicitam que os usuários abram a boca, pisquem, mexam a cabeça, identificam elementos básicos dos rostos ou necessitam de superfícies retas.

\footnotetext{
${ }^{12}$ Disponível em https://sparkar.facebook.com/ar-studio/ Acesso em 20 de out. de 2019.
} 
Os efeitos são diversos, desde aprimoramento da pele, maquiagens, inserção de coroas, brilhos, deformações, inserções de animais e outros seres, cores, formas em movimento, desenhos, referências a elementos da cultura pop, testes, sorteios, simulações de lugares, entre muitos outros. Acaba por depender da criatividade dos desenvolvedores e dentro do que a plataforma permite as possibilidades até o momento não se esgotaram.

Alguns exemplos abaixo foram retirados do aplicativo:

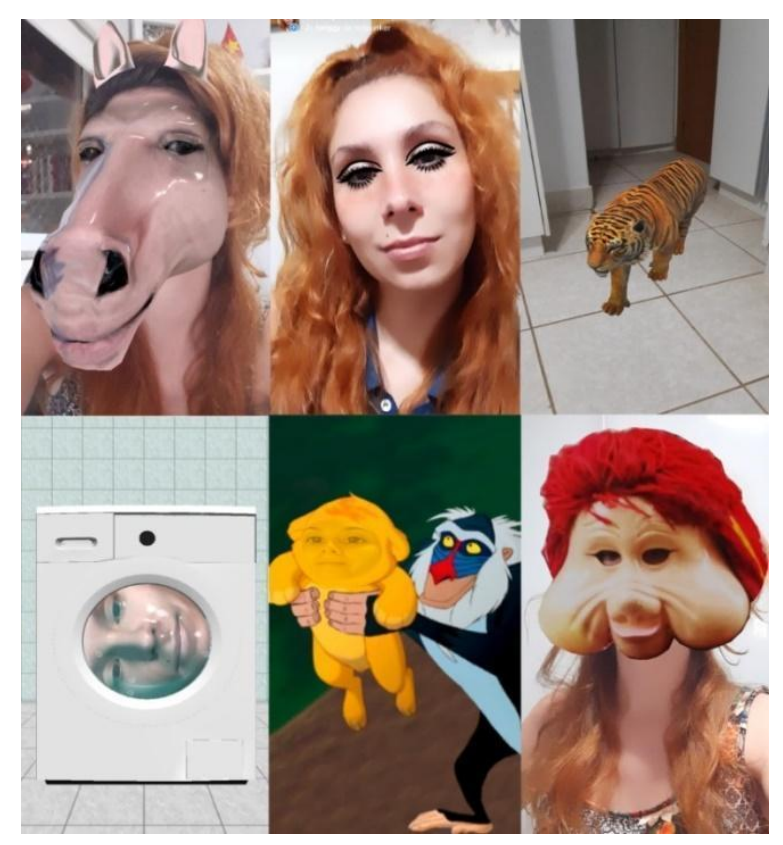

Figura 15: Print Screen retirados do aplicativo Instagram

Manovich concebe um novo termo a respeito da estética contemporânea digital, o instagramismo, referindo às vanguardas artísticas:

$\mathrm{Eu}$ uso esse termo como uma analogia aos movimentos de arte moderna, como o futurismo, o cubismo, o surrealismo etc. Como esses primeiros ismos, o Instagramismo oferece sua própria visão do mundo e sua linguagem visual. Mas ao contrário dos movimentos de arte modernistas, o instragram é moldado por milhões de autores conectados por participando, Instagram e outras redes sociais. (Aplicativo de edição de fotos VSCO considerado o padrão entre Instagrammers sofisticados tinha 30 milhões de usuários ativos no início de 2016.) Eles influenciam uns aos outros e compartilham conselhos sobre o uso de aplicativos de foto móvel para criar, editar e fotos de sequência a serem compartilhadas no Instagram. (MANOVICH, 2016, p. 4 - tradução nossa) 
Retoma o conceito de meios de produção de Karl Marx (1859), no que pode colocar o Instagram como um meio de produção cultura, de forma a entender as regras do aplicativo e as estratégias de aplicação na prática e usar as habilidades aprendidas na rede para se criar capital cultural.

Porém, Manovich propõe uma atualização desses termos:

Trabalhadores estéticos e sociedade estética (ou seja, a sociedade do consumidor esteticamente sofisticado bens e serviços). Em tal sociedade, produção e apresentação de belas imagens, experiências, estilos, e os projetos de interação do usuário são centrais para seu funcionamento econômico e social. Em vez de ser uma propriedade da arte, a estética é a propriedade chave dos bens e serviços comerciais. (Assim, a sociedade estética é não é o mesmo que A Sociedade do Espetáculo por Guy Debord, 1967). (MANOVICH, 2016, p. 4 e 5 tradução nossa)

Nessa sociedade estética, a inteligência artificial já está automatizando as escolhas estéticas dos usuários com o recurso das recomendações, sobre o que se deve ouvir, assistir ou usar, baseando nos interesses estabelecidos pelos algoritmos. Manovich prevê que o uso da inteligência só irá aumentar e desempenhar um papel ainda maior na produção cultural profissional, uma vez que as decisões finais ainda são deliberadas por humanos que realizam a produção real com base em ideias e mídias que foram geradas pela linguagem digital (MANOVICH, 2017, p. 3 - tradução nossa).

Há alguns aspectos perversos na questão da utilização dos filtros nas redes, especialmente no que tange à autoimagem e a busca pela perfeição absolutamente idealizada de uma imagem que é artificial. Estudos relatam um fenômeno preocupante em vários pacientes jovens, especialmente mulheres, que é um tipo de dismorfia corporal desencadeada pelo estresse associado aos filtros e que solicitam procedimentos cirúrgicos para parecerem mais simétricos. Ou, mais grave ainda, para que suas características físicas se aproximassem dos filtros utilizados sob a justificativa de ficarem melhor nas redes. Além de toda uma questão bastante problemática acerca de filtros que realizam um embranquecimento, ou seja, clareiam a pele dos negros ou afinam seus narizes e bocas. Novamente lembrando o quanto nenhuma dessas relações são neutras e como esses dados demonstram a clara confusão entre o que é real e virtual, de forma que as pessoas estão tentando atingir o inatingível que é a criação absolutamente artificial que são os filtros.

No ano de 2020 houve um crescimento exponencial da rede social de vídeos em formato curto, o TikTok, com mais de 50 milhões de downloads ao redor do mundo. 
TikTok ${ }^{13}$ é, de acordo com a própria definição da rede social chinesa:

TikTok é o destino para vídeos para celular. No TikTok, vídeos curtos são emocionantes, espontâneos e genuínos. Seja você um fanático por esportes, um entusiasta de animais de estimação ou apenas uma gargalhada, há algo para todos no TikTok. Tudo o que você precisa fazer é assistir, se envolver com o que você gosta, pular o que não gosta e você encontrará um fluxo interminável de vídeos curtos que são personalizados apenas para você. Do café da manhã às tarefas da tarde, o TikTok tem os vídeos que garantem o seu dia.

Facilitamos a descoberta e a criação de seus próprios vídeos originais, fornecendo ferramentas fáceis de usar para visualizar e capturar seus momentos diários. Leve seus vídeos para o próximo nível com efeitos especiais, filtros, músicas e muito mais. (...)

Assista a todos os tipos de vídeos, desde Comédia, Jogos, Faça você mesmo, Comida, Esportes, Memes e Animais de estimação, até Estranhamente Satisfatório, ASMR e tudo mais. (...)

- Ser entretido e inspirado por uma comunidade global de criadores

Milhões de criadores de conteúdo estão no TikTok, mostrando suas incríveis habilidades e a vida cotidiana. Deixe-se inspirar. (...)

Desbloqueie toneladas de filtros, efeitos e objetos RA para levar seus vídeos ao próximo nível.

- Edite seus próprios vídeos

Nossas ferramentas de edição integradas permitem aparar, cortar, mesclar e duplicar clipes de vídeo com facilidade, sem sair do aplicativo. (Definição pelo site, 2020, - tradução nossa)

Assim, é possível entender que a rede retoma a lógica dos primeiros cinemas, a do chamado cinetoscópio, que era um instrumento de projeção que possuía um visor individual que exibia pequenos filmes em looping e as temáticas geralmente eram cômicas. Podendo relacionar a questão da conjuntura histórica da visualidade com a forma que no TikTok temos essas imagens que são consumidas rapidamente, criando narrativas dentro do aplicativo que são visualmente voltadas para o entretenimento em um volume monumental de produção.

Na classificação da Sense Tower, o aplicativo chinês conta com a maior pontuação atribuída pelo site, A+.

13 Disponível em: <https://apps.apple.com/us/app/tiktok-make-your-day/id835599320> Acesso em Acesso em 06 de jun. de 2020. 


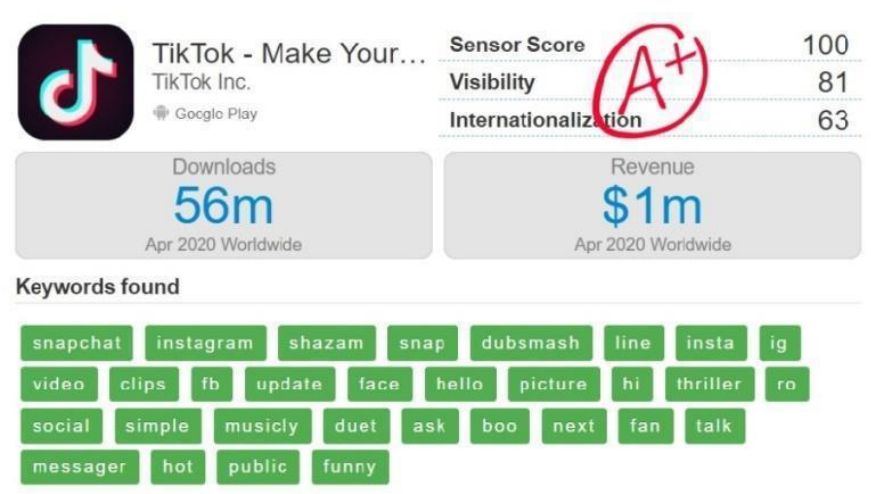

Figura 16: Sensor Tower ${ }^{14}$ - Abril de 2020 em busca sobre "Data That Drives App Growth"

Essa rede reitera a questão da criação de conteúdo, fornecendo filtros, efeitos e RA para que o sujeito efetue seus próprios vídeos, sendo prosumers (consumidores e produtores de conteúdo simultaneamente).

Um fator bastante notável é a popularidade da rede entre os jovens que rapidamente entendem o funcionamento da nova literacia e já incorporam em seus cotidianos, os considerados nativos digitais que utilizam seu tempo interagindo por meio das ferramentas de comunicação e tem um potencial de criatividade, tal como afirmado por Passarelli, "que gera efeitos colaterais como aprendizagem autodirigida, aprimoramento do uso das ferramentas (literacia digital) e desenvolvimento de interesses permanentes" (PASSARELLI, 2009, p. 7).

Assim, criam filtros e utilizam outros filtros na produção de seus conteúdos de forma que vai tomando uma proporção de disseminação rizomática, uma vez que vão se criando muitos pontos de compartilhamento, como por exemplo, os chamados desafios em que se propõe uma dança ou uma dublagem ou qualquer outra ação.

Isso vai se disseminando sem saber quem foi o primeiro a inventar essa proposta e a autoria ou propriedade intelectual pouco importa nessa rede, uma vez que seu intuito é para ser absorvida rapidamente e seguir para o próximo conteúdo, reflete bastante o conceito de cultura do remix de Manovich.

\footnotetext{
${ }^{14}$ Disponível em: <https://sensortower.com/> Acesso em 05 de abril de 2019.
} 


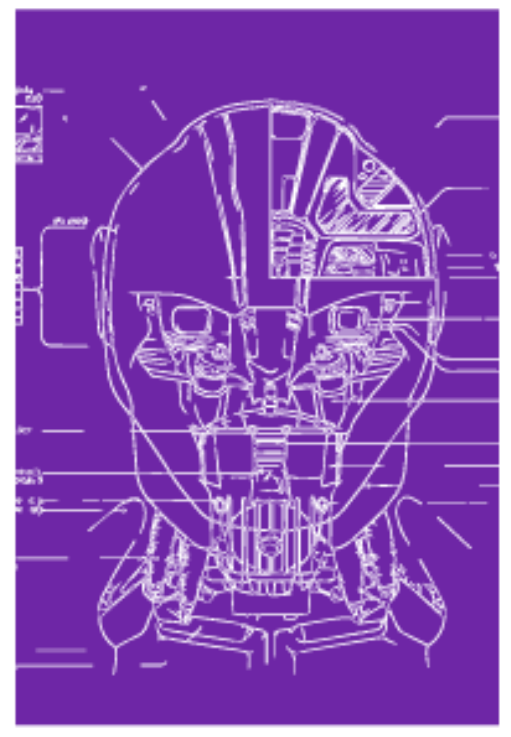

Capítulo III - Video games e realidade aumentada 


\section{CAPÍTULO III - VIDEOGAMES E REALIDADE AUMENTADA}

Neste capítulo tem-se uma investigação específica sobre a indústria dos videogames, com dados advindos de pesquisas acerca do mercado, do perfil dos jogadores e dos valores de investimento destinados à área. Além disso, realizamos uma análise do jogo em realidade aumentada Pokémon GO e um comentário sobre o jogo Minecraft Earth.

\section{1) Contexto mundial e local da indústria dos Videogames}

Mostrou-se fundamental o aprofundamento acerca dos videogames, no sentido de ser uma indústria em plena ascensão e em como, juntamente com as redes sociais é um fator que definitivamente popularizou o acesso à linguagem da realidade aumentada a partir do uso de aplicativos que a utilizam. Trazemos aqui indicadores mundiais e locais de forma a criar um mapeamento acerca do contexto dos videogames.

Esse facilitador se dá devido ao crescimento das opções em lojas em aplicativos e principalmente pelo recente acesso a dispositivos móveis inteligentes, tais como o smartphone e o tablet, de forma em que possibilitam a disseminação e o acesso à informação. Alguns desses videogames em dispositivos móveis utilizam R.A. dos quais se destacam em popularidade o Pokémon GO, Zombies Run! e Ingress.

No caminho de videogames que estabelecem uma relação de interação com o corpo é necessário ressaltar a importância de jogos de console, ou seja, que não são em dispositivos móveis, tais como Wii e Kinect, que criaram uma personalização do contato com o corpo do jogador, demandando uma maior movimentação do que outros videogames que não se demandam corporalmente, investindo em aprofundamentos mentais com desenvolvimento de narrativas e estratégias.

Antes de entrar especificamente em videogames em realidade aumentada, parece relevante um estudo sobre o funcionamento conceitual desses sistemas e que de acordo com Bogost (2007):

Os videogames são um meio expressivo. Eles representam como os sistemas reais e imaginários funcionam. Eles convidam os jogadores a interagir com esses sistemas e formar julgamentos sobre eles. Como parte do processo contínuo de entender esse meio e impulsioná-lo ainda mais como players, desenvolvedores e críticos, devemos nos 
esforçar para entender como construir e criticar as representações do nosso mundo na forma de videogame. (BOGOST, 2007, p. 8 tradução nossa)

Bogost entende que ainda existe uma busca por legitimidade, uma vez que muitas vezes, de forma limitante, são entendidos como sem funções culturais ou sociais, ou no máximo como uma estratégia de distração. Sugere, portanto, com seu estudo, que os videogames na verdade possibilitam um novo domínio para a persuasão, "graças ao seu núcleo representacional modo, proceduralidade ${ }^{15}$. Chamo essa nova forma de retórica processual, a arte da persuasão através representações e interações baseadas em regras, em vez da palavra falada, escrita, imagens ou imagens em movimento" (BOGOST, 2007, p. 10 - tradução nossa).

De acordo com Sakuda (2018):

Os jogos digitais entraram definitivamente no mundo dos negócios, deixando para trás a fase em que eram considerados produtos feitos de maneira amadora. Atualmente, movimentam uma grande indústria do segmento da economia criativa e tecnológica, que tem registrado crescimento acelerado em todo mundo. Os jogos ganharam status importante em diversos setores da economia, pelo seu potencial de uso em campos como educação, treinamento e simulação de situações profissionais. A Indústria de Jogos Digitais (IJD) é importante não somente pela capacidade de geração de emprego e renda, mas também pela vocação de promover a inovação tecnológica para diferentes áreas como arquitetura e construção civil, marketing e publicidade, saúde, educação e defesa, treinamento e capacitação, entre outros. (SAKUDA, p. 245, 2018)

Assim são um tipo diferente de persuasão típica dos recursos do computador, de executar processos, cálculos e manipulações simbólicas baseadas em regras, os videogames têm um poder diferente, pois "são artefatos computacionais que têm significado cultural como artefatos. Além disso, eles são uma forma popular de artefato computacional, talvez a forma mais prevalente de computação expressiva" (BOGOST, 2007, p. 10 - tradução nossa). Esse poder está principalmente na maneira como montam reivindicações por meio de procedimentos retóricos, e em como possuem o poder de montar expressões significativas.

Sobre a retórica visual dos videogames, entende que é um meio que implanta imagens estáticas e em movimento, mas que, no entanto, “apesar de seu possível valor

\footnotetext{
${ }^{15}$ Proceduralidade é definida pelo autor como um modo de criar, explicar ou entender processos.
} 
para a mídia digital, a retórica visual não pode nos ajudar abordar a função retórica da representação processual” (BOGOST, 2007, p. 24 - tradução nossa).

Assim, em procedimentos como videogames as imagens são frequentemente construídas, selecionadas ou sequenciadas em código, tornando inadequadas as ferramentas de estoque da retórica visual, a imagem é subordinada ao processo (BOGOST, 2007, p. 25 - tradução nossa). Geralmente entende-se a retórica digital com foco no conteúdo de texto e imagem que uma máquina "pode hospedar e comunidades de prática nas quais esse conteúdo é criado e usado" (BOGOST, 2007, p. 25 - tradução nossa).

Sugere, portanto, um novo domínio da retórica processual:

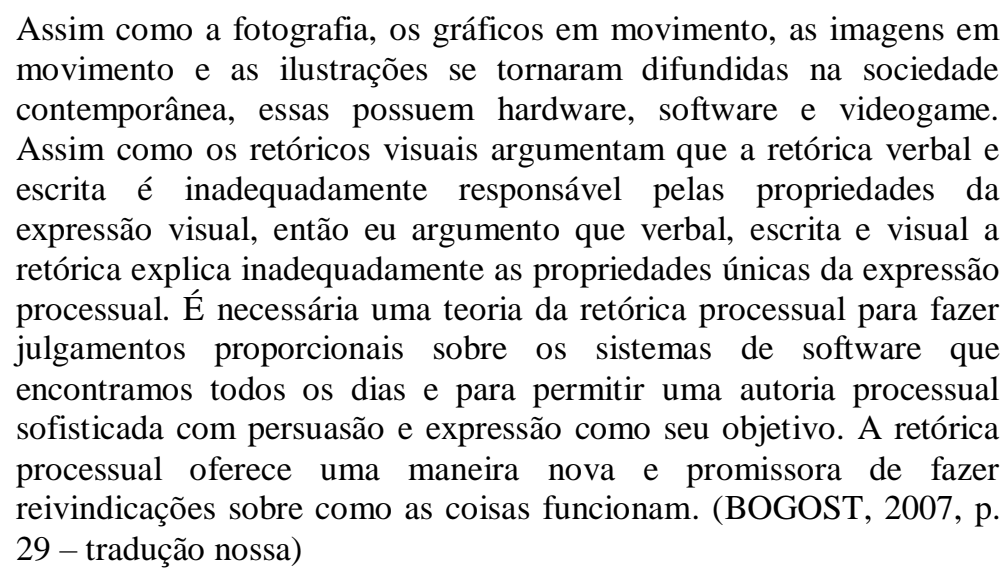

De forma que o jogador/sujeito ao envolver-se na experiência do videogame refere-se à possibilidade de espaço criado pelos próprios processos, "é isso que fazemos quando jogamos videogames: exploramos a possibilidade do espaço que é dominado por suas regras ao manipular os controles do jogo" (BOGOST, 2007, p. 43 - tradução nossa), sendo nesse espaço que se forjam as relações e se dá a experiência.

Sobre a simulação e interatividade:

Argumentei que a posição ontológica de um videogame (ou simulação ou sistema processual) reside na lacuna entre a representação baseada em regras e subjetividade do jogador; chamei esse espaço de "lacuna de simulação". Outra maneira de pensar sobre a lacuna da simulação é em relação à retórica. O modelo processual como um videogame poderia ser visto como um sistema, de reivindicações processuais individuais de que o jogador completa literalmente através da interação. (BOGOST, 2007, p. 43 - tradução nossa) 
Entendendo que a interatividade é um processo cíclico em que os atores envolvidos (jogadores/sujeitos) alternam suas ações em pensar, ouvir, falar e decidir, assim, a qualidade dessas interações depende da complexidade das subtarefas que devem realizar.

A verdade é que quanto mais comunicação significa mais capital em que a “circulação acelerada de comunicação e informação leva à circulação acelerada de capital" (HAN, 2018, p. 66), por isso a importância da discussão do aspecto mercadológico por trás da R.A. e o quanto seu investimento não pode ser desvencilhado da economia que proporciona tamanha movimentação de recursos e conhecimento advindo dessas grandes empresas.

A indústria dos videogames é indubitavelmente uma das indústrias com maior crescimento e investimento mundial. É importante construir um breve panorama desse mercado, trazendo dados e informações relativos ao contexto mundial e especificamente sobre o mercado brasileiro em ascensão. Assim, buscamos pesquisas que coletaram esses dados desde 2014 até 2019, intentando-se compreender de forma geral como se deu esse cenário nesse período específico de tempo.

Em 2018, foi realizada a 19ª Pesquisa Global de Entretenimento e Mídia (Global Entertainment \& Media Outlook 2018-2022) pela $\mathrm{PwC}^{16}$, na qual investigaram os gastos dos consumidores e dos anunciantes em quinze segmentos de entretenimento e mídia em 53 países, incluindo o Brasil. Pontuaram cinco fatores fundamentais da mudança: conectividade onipresente, mobilidade, necessidade de novas fontes de crescimento de receita, mudança de valor para plataformas e personalização.

Das quais são necessários destacar sua importância:

Conectividade onipresente: investimentos em tecnologia e infraestrutura e rede de banda larga expandiram a cobertura, capacidade, largura de banda e conectividade de forma que os consumidores e seus dispositivos estão sempre conectados e sempre. Esses desenvolvimentos estão em constante crescente e com diversidade de conteúdos, experiências e aplicativos que podem ser entregues direta e digitalmente para os usuários.

Mobilidade do consumidor: com o crescimento de gastos, o dispositivo móvel conectado tornou-se rapidamente o principal dos meios dos consumidores de acessarem o conteúdo e serviços em praticamente todos os mercados no mundo todo. Isso torna imperativo

\footnotetext{
${ }^{16}$ Disponível em: https://www.pwc.com.br/pt/outlook-18.html. Acesso em 01 de fev. de 2020.
} 
para criadores de conteúdo, distribuidores e plataformas para desenvolver os meios, alcançar e monetizar consumidores móveis diretamente através de experiências móveis ao invés de vendas tradicionais e outras abordagens de distribuição. (Global Entertainment \& Media Outlook 2018-2022, p. 6, 2018 - tradução nossa)

Assim, o investimento nos videogames são os em maior crescimento e também em publicidade digital, essa que opera dentro da lógica das redes e da utilização da mobilidade do consumidor, tal como percebido no gráfico abaixo:

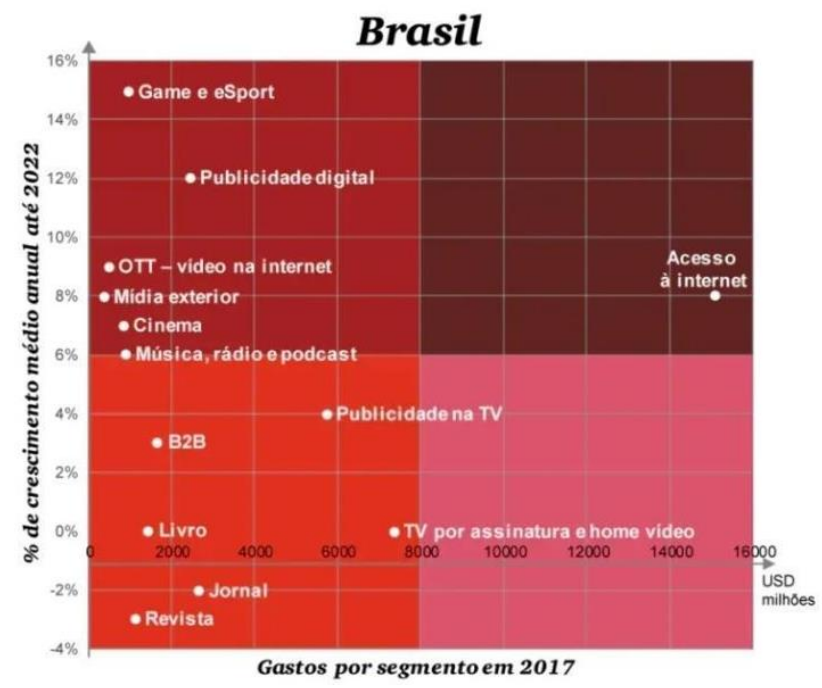

Figura 17: Global Entertainment \& Media Outlook 2018-2022 por PwC ${ }^{17}$

Assim, pontuaram que o mercado de videogames brasileiro deve crescer em torno de 5,3\% até 2022 e as receitas de aplicativos de realidade virtual, jogos e vídeos foram de \$3,9 bilhões de dólares em 2017. Além disso, marcaram como tecnologias essenciais robôs, internet das coisas, realidade aumentada, realidade virtual, blockchain, inteligência artificial, impressão 3D e drones, tal como no gráfico abaixo.

17 Disponível em: <https://www.pwc.com/gx/en/entertainment-media/outlook/perspectives-from-theglobal-entertainment-and-media-outlook-2018-2022.pdf>. Acesso em 11 de mar. de 2020. 


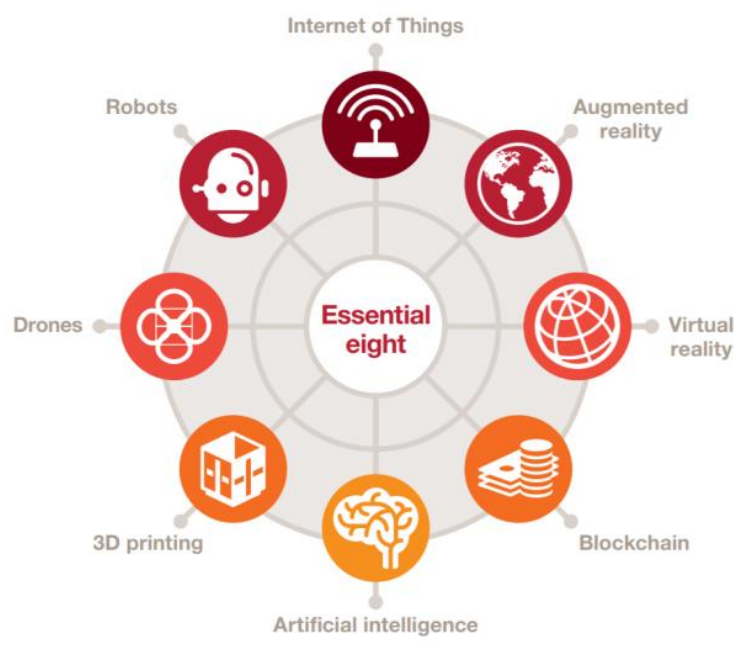

Figura 18: Global Entertainment \& Media Outlook 2018-2022 por $\mathrm{PwC}^{18}$

Quanto às expectativas de gasto dos consumidores em relação a entretenimento e mídia com a porcentagem mais alta para comunicação, com $28,5 \%$ e para games com $27,8 \%$.

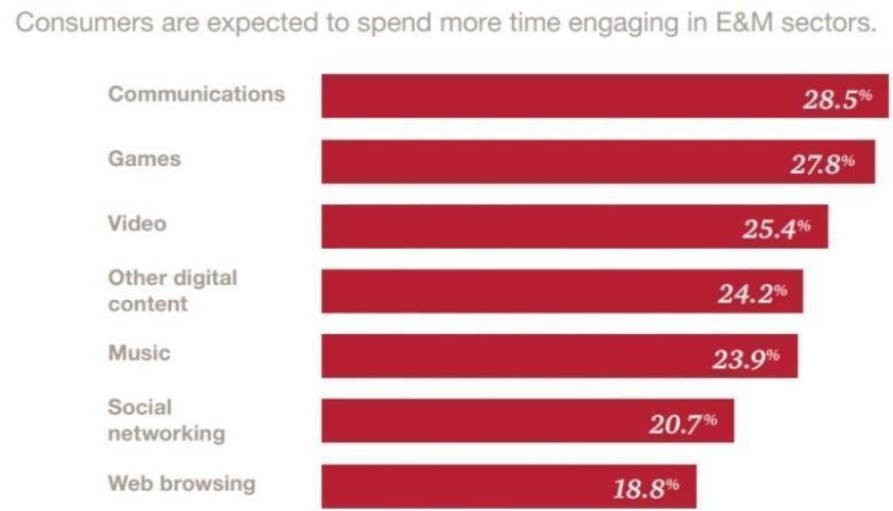

Source: PwC Global Entertainment \& Media Outlook 2018-2022, www.pwc.com/outlook

Figura 19: Global Entertainment \& Media Outlook 2018-2022 por PwC

Outra pesquisa importante foi a realizada pela Newzoo ${ }^{19}$, empresa que trabalha com análises do mercado de jogos, uma prestação de serviços para outras empresas de entretenimento, tecnologia e mídia para que possam atingir seu público, rastrear

18 Disponível em: <https://www.pwc.com/gx/en/entertainment-media/outlook/perspectives-from-theglobal-entertainment-and-media-outlook-2018-2022.pdf> Acesso em 11 de mar. de 2020.

${ }^{19}$ Disponível em: <https://newzoo.com/>. Acesso em 21 de mar. de 2020. 
concorrentes, identificar oportunidades e tomar decisões estratégicas e financeiras. Em 2019 lançaram um relatório ${ }^{20}$ Global Games Market Report no qual afirmam que o mercado dos games tem uma renda de 152,1 bilhões de dólares com um aumento de $9,6 \%$ ano a ano até 2022 :

Os jogos para celular (smartphone e tablet) continuam sendo o maior segmento em 2019, produzindo receita de US \$ 68,5 bilhões - $45 \%$ do mercado global de jogos. De todas as receitas de jogos para dispositivos móveis, $80 \%$, ou US \$ 54,9 bilhões, virão de jogos para smartphones, com os jogos para tablet respondendo pelos US \$13,6 bilhões restantes. (Global Games Market Report 2019, p. 11, 2019 tradução nossa)

De acordo com os dados em comparação com regiões do mundo, a América latina tem a menor receita, com 5.6 bilhões de dólares, sendo que a maior receita vem da Ásia, com 72.2 bilhões de dólares, com $47 \%$ do total, as outras regiões estão detalhadas no gráfico:

2019 GLOBAL GAMES MARKET

PER REGION

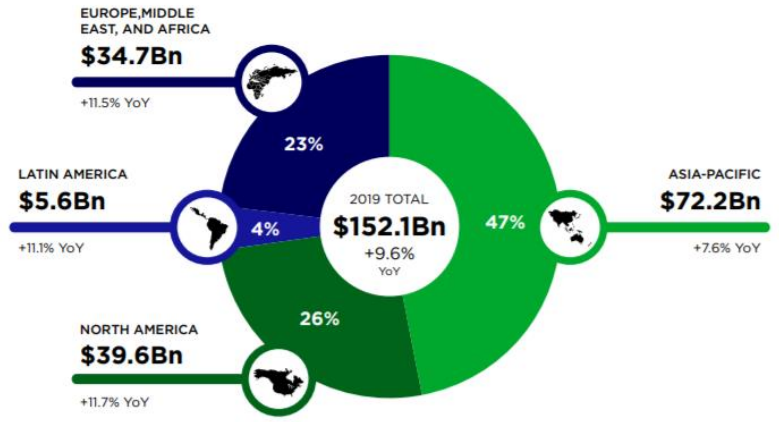

Figura 20: Global Games Market Report 2019

No entanto dentro do mercado latino, o Brasil se destaca com 1,6 bilhões de dólares, estando atrás apenas do México com 1,8 bilhões, como se percebe no gráfico abaixo.

\footnotetext{
${ }^{20}$ Disponível em: https://newzoo.com/solutions/standard/market-forecasts/global-games-market-report/. Acesso em 21 de mar. de 2020.
} 


\title{
LATIN AMERICA
}

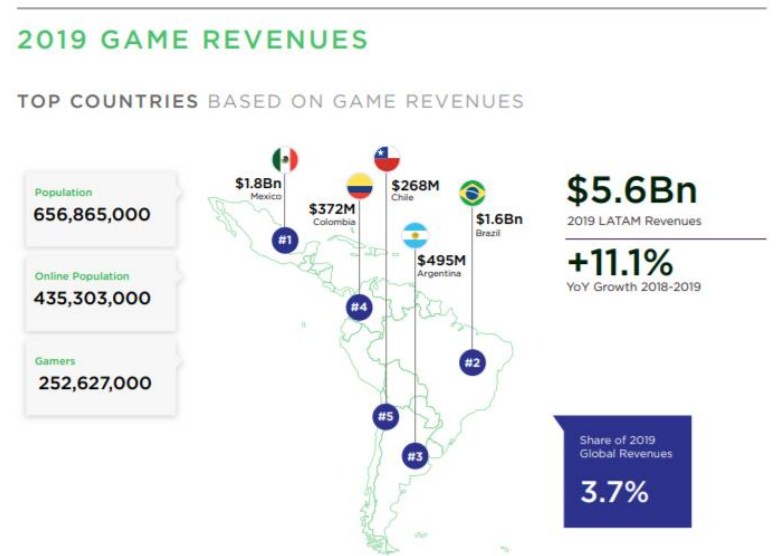

Figura 21: Global Games Market Report 2019

Na pesquisa, destacam a questão da nostalgia como uma fonte de capitalização, uma vez que:

\begin{abstract}
A nostalgia sempre foi um ponto de venda essencial no mercado de jogos, com algumas das maiores franquias de hoje, incluindo Mario, Final Fantasy e Pokémon, nascidas já no início dos anos 80 . Procurando aproveitar a nostalgia dos consumidores, as empresas estão relançando e refazendo o conteúdo retro - e até o hardware - dos anos passados. Portar jogos mais antigos para o hardware atual sempre foi comum; por exemplo, a Nintendo tradicionalmente portou seus títulos mais antigos para seus consoles portáteis, como o Game Boy (Color / Advance) e para o console via seu Console Virtual e agora Nintendo eShop. Na geração anterior do console (Xbox 360 e PlayStation 3), remasters HD eram uma possibilidade. Muitos editores perceberam que os consumidores estão dispostos a recomprar títulos mais antigos a uma taxa reduzida para recursos visuais aprimorados ou ligeiramente atualizados. (Global Games Market Report 2019, p. 11,2019 - tradução nossa)
\end{abstract}

Em dezembro de 2019, no canal oficial do Pokémon no YouTube, lançaram um vídeo chamado Buddy Adventures, no qual fica bastante evidente a questão da retomada da nostalgia.

A narrativa se concentra ao redor de uma criança e um brinquedo que recebe dos pais, um Pokémon. Realiza todas as atividades com ele, inclusive o alimenta, brinca com a irmã e leva para a escola. Posteriormente aparece o menino agora já adulto brincando com o mesmo Pokémon, só que pelo aplicativo Pokémon GO, realizando 
inclusive as mesmas ações juntas como alimentar o Pokémon com uma fruta ou andar junto na rua. Em alguns frames retirados do vídeo do YouTube é possível entender o apelo à nostalgia.

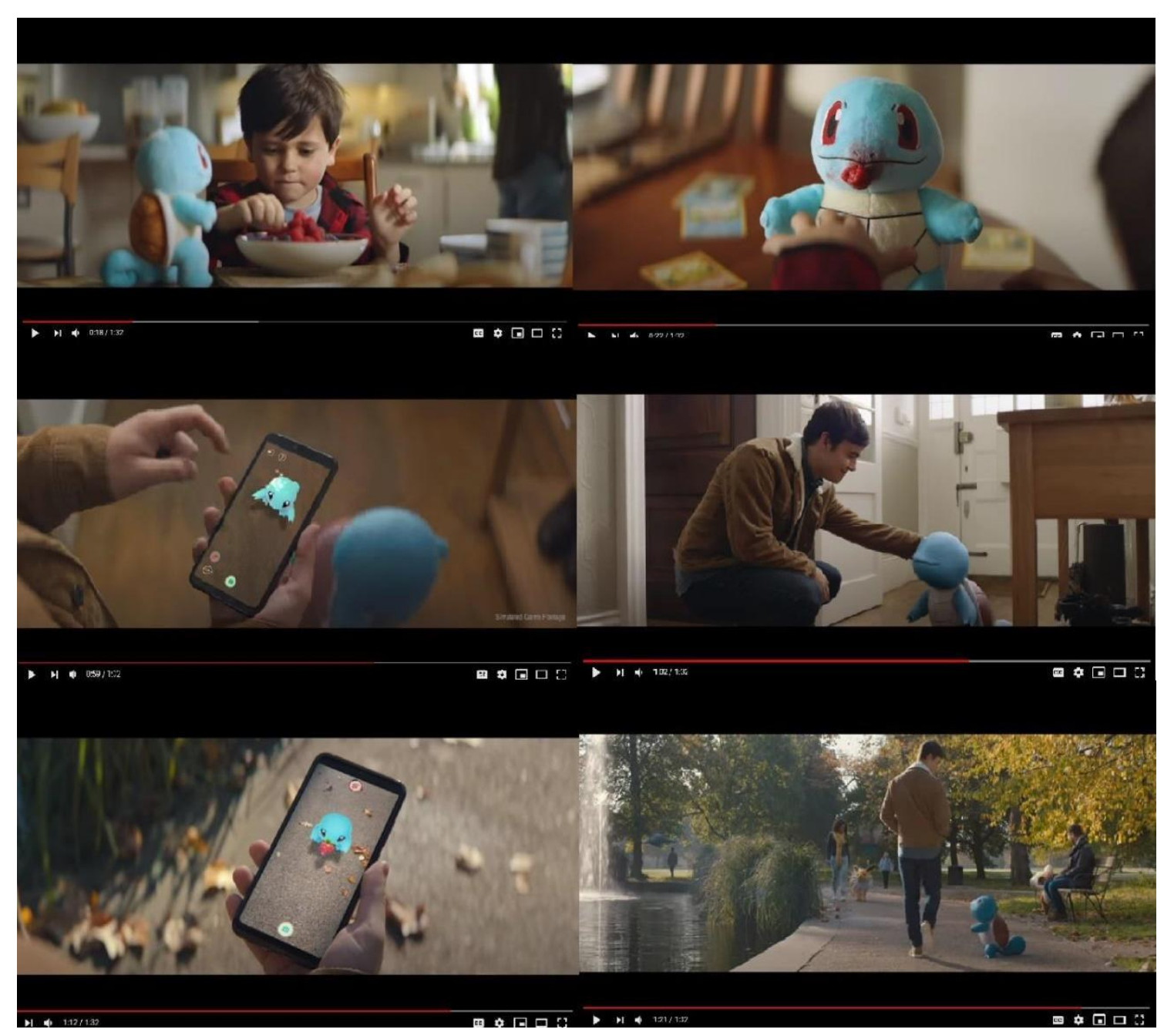

Figura 22: Frames do vídeo Buddy Adventures ${ }^{21}$ no canal oficial do YouTube lançado em dezembro de 2019 com 2,791, 450 visualizações em abril de 2020

Lançamentos de remakes tem sido uma tendência não apenas nos jogos, mas também no cinema que vem retomando antigos sucessos, para a pesquisa levantada pela Newzoo:

Capitalizar a nostalgia vai além do lucro em curto prazo. Remakes ou remasters podem reacender a paixão que os jogadores têm (ou tiveram) pelas franquias e permitem que o editor leve essas amadas franquias para a era moderna, potencialmente estendendo o cronograma desses jogos por mais uma década ou mais. Também oferecem uma oportunidade de modernizar o modelo de receita desses

${ }^{21}$ Disponível em: 〈https://www.youtube.com/watch?time_continue=82\&v=C461fBV-J7c>. Acesso em Acesso em 10 de fev. de 2020. 
títulos clássicos. Aproveitar a nostalgia oferece aos editores a chance de gerar receita com jogos muito além o sucesso inicial do jogo, mas o sucesso comercial e crítico não é o único benefício para editores. Remanejar jogos dessa maneira consome menos tempo e é mais econômico do que criar um título totalmente novo. Afinal, os desenvolvedores já têm uma fundação, incluindo design de personagens, layout de nível e história, a partir da qual construir. Este fornece outra maneira para as empresas produzirem receita estável juntamente com as ofertas de jogos como serviço. Também redireciona conteúdo antigo para públicos novos e mais jovens, que esperam ver visuais de alta fidelidade nos jogos. (Global Games Market Report 2019, 2019, p. 17 - tradução nossa)

Ou seja, a capitalização da nostalgia busca atingir públicos antigos e fidelizados e novos públicos mais jovens.

Concentrando-se especificamente sobre o mercado brasileiro, em 2018, o Ministério da Cultura (MinC) e a Organização das Nações Unidas para a Educação, a Ciência e a Cultura (Unesco) realizaram o $2^{\circ}$ Censo da Indústria Brasileira de Jogos Digitais $^{22}$, estudo que indicou dados dos a anos 2014 a 2018, acerca do crescimento do mercado de jogos eletrônicos no território brasileiro, com um recorte de seis tipos de públicos:

\begin{abstract}
Foram previstos seis tipos de públicos: 1) desenvolvedoras formalizadas; 2) desenvolvedoras não formalizadas; 3) organizações de apoio ao desenvolvimento e serviços em jogos digitais formalizadas; 4) organizações de apoio ao desenvolvimento e serviços em jogos digitais não formalizadas; 5) profissionais autônomos formalizados (emite recibo de pagamento autônomo - RPA ou nota fiscal como microempreendedor individual - MEI); 6) profissionais autônomos não formalizados. (SAKUDA, 2018, p.5)
\end{abstract}

A amostra do Censo foi a partir de 695 questionários, sendo 375 desenvolvedoras de jogos digitais, 233 profissionais autônomos e 85 organizações de ao desenvolvimento e serviços em jogos digitais (SAKUDA, 2018, p.10). Dessa forma, indicaram um crescimento de $182 \%$ em quatro anos, tomando como referência o primeiro censo realizado no ano de 2014.

O crescimento do número de desenvolvedores de software no Brasil "cresceu em média 9,07\% ao ano entre 2007 e 2014. Tendo essa média como base, a projeção de

\footnotetext{
${ }^{22}$ Disponível em: <https://nuvem.cultura.gov.br/index.php/s/mdxtGP2QSYO7VMz\#pdfviewer>. Acesso em 15 de dez. de 2019.
} 
crescimento seria próxima a 41,5\% no número de desenvolvedoras num período de quatro anos, bastante abaixo do encontrado" (SAKUDA, 2018, p.11).

Comparando o número de empresas brasileiras que desenvolveram jogos "nos últimos quatro anos foi cerca de 4,5 vezes a média de crescimento das desenvolvedoras de software" (SAKUDA, 2018, p.11), apontando que 26,4\% das desenvolvedoras respondentes ainda atuam na informalidade que pode estar "associado a diversos fatores, entre os quais destacam-se particularmente a questão tributária" além dos "riscos de empreender são altos e a baixa disponibilidade de capital financeiro para suportar o empreendimento formal é bastante evidente (SAKUDA, 2018, p.11).

Em relação ao primeiro censo, as empresas se espalharam por outras regiões que não apenas as metropolitanas:

No I Censo, apenas 23,3\% das empresas estavam fora das capitais. No II Censo, 27,9\% das empresas formalizadas estão fora das capitais; no entanto, entre as não formalizadas, $52,5 \%$ estão fora das capitais. Isso mostra que, além do pequeno crescimento entre as formalizadas, a indústria está começando a ter uma capilaridade maior fora dos grandes centros. Os dados apontam uma indústria em franco crescimento e de abrangência nacional, presente tanto nas capitais como no interior dos estados. (SAKUDA, 2018, p.16).

Sendo que o sudeste do país ainda concentra a maior quantidade de desenvolvedoras e o norte com o menor número, tal como na figura:

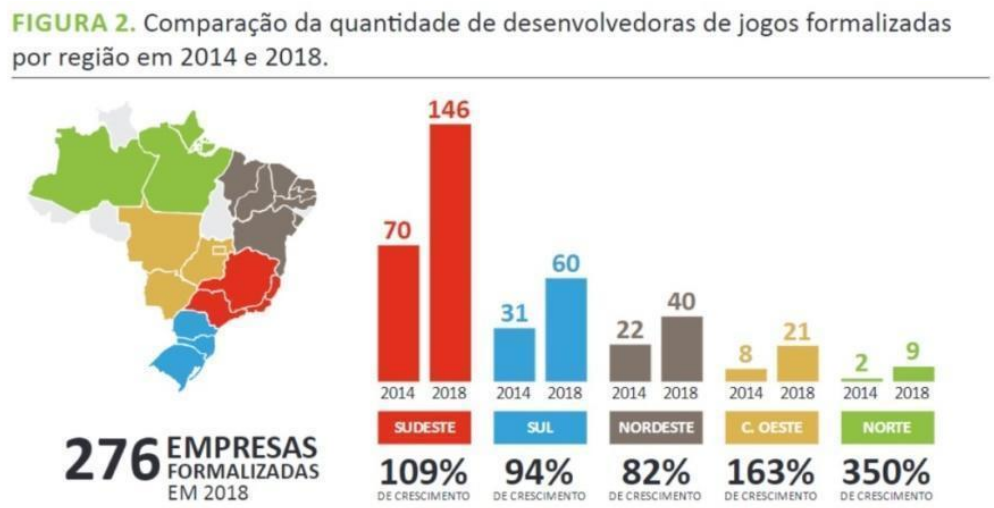

Figura 23: $2^{\circ}$ Censo da Indústria Brasileira de Jogos Digitais (2018)

Entre as atividades mais desenvolvidas estão os jogos com 95,5\% e os softwares e serviços em tecnologia da informação com $31,4 \%$, animação é realizada por $25,7 \%$ 
das empresas, sendo que "quase $23 \%$ das empresas realizam serviços educacionais, $20,8 \%$ prestam consultoria, $16,3 \%$ realizam treinamento corporativo e $12,4 \%$ trabalham com publicidade e propaganda" (SAKUDA, 2018, p.18).

Um aspecto importante apontado é o fator de gameficação, que seria a utilização dos jogos para ludificação de situações de treinamento e "pode explicar porque os serviços de treinamento corporativo estão no setor do desenvolvimento de jogos" (SAKUDA, 2018, p.20).

Sobre o faturamento das empresas que desenvolvem jogos no Brasil percebe-se que a porcentagem ainda é baixa para altos rendimentos, na casa dos milhões.

Algo que se destaca no censo é o alto número de investimento em jogos nas plataformas de smartphones e tablets, como se percebe abaixo:

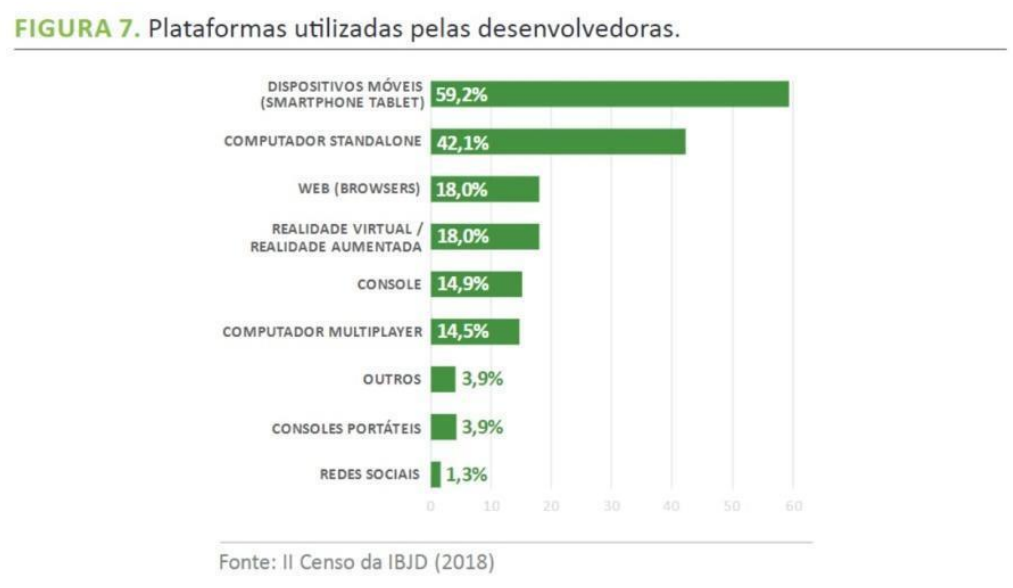

Figura 24: $2^{\circ}$ Censo da Indústria Brasileira de Jogos Digitais (2018)

Outro destaque levantado é que $18 \%$ das empresas desenvolvem jogos para realidade virtual/aumentada, "tecnologias apontadas como emergentes, que deveriam ser observadas pelas empresas como uma nova arena de competição onde a indústria local poderia se inserir simultaneamente com empresas da indústria internacional" (SAKUDA, 2018, p.33).

Ficou evidente pelo censo que esta área de desenvolvimento tem pouca diversidade, como por exemplo, o número irrisório de colaboradores trans, em torno de $0,4 \%$ apenas, conforme tabela abaixo: 
TABELA 16. Número de afrodescendentes, indígenas, trans e estrangeiros nas desenvolvedoras.

\begin{tabular}{rcc} 
GRUPO & N DE SÓCIOS E COLADORADORES & $\%$ \\
\hline Afrodescendentes & 273 & $10 \%$ \\
\hline Indígenas & 24 & $0,9 \%$ \\
\hline Trans & 12 & $0,4 \%$ \\
\hline Estrangeiros & 25 & $0,9 \%$ \\
\hline TOTAL & 334 & $12,2 \%$
\end{tabular}

265 respondentes (147 não tem ninguém nos grupos acima)

Fonte: II Censo da IBJD (2018)

Figura 25: $2^{\circ}$ Censo da Indústria Brasileira de Jogos Digitais (2018)

A diferença das relações de gênero também é gritante, uma vez que as mulheres pouco têm representatividade em áreas técnicas relacionadas ao desenvolvimento de jogos, estando presente em áreas de apoio, tais como a área administrativo-financeira e em outras áreas de negócio, das quais:

Do total de empregados e sócios, $63,8 \%$ são homens e $36,2 \%$, mulheres. A opção em que aparece maior equilíbrio entre a quantidade de homens e mulheres é 'Outras áreas do negócio', com 57,2\% das pessoas da área sendo homens e 42,8\% mulheres, entre sócios e empregados. As áreas administrativo-financeira e marketing e vendas apresentam a distribuição de 1,5 e 1,8 homens para cada mulher, respectivamente. A área com maior diferença de gênero é a de programação e gestão de projetos, com $82,3 \%$ de homens e $17,7 \%$ de mulheres, ou seja, 4,6 homens para cada mulher na área. (SAKUDA, 2018, p. 96)

\begin{tabular}{|c|c|c|}
\hline & HOMENS & MULHERES \\
\hline $\begin{array}{r}\text { PROGRAMAČ̃̃o } \\
\text { E GESTÃO DE PROJETOS }\end{array}$ & $82,3 \%$ & $17,7 \%$ \\
\hline $\begin{array}{r}\text { ARTE } \\
\text { E DESIGN }\end{array}$ & $73,3 \%$ & $26,7 \%$ \\
\hline $\begin{array}{r}\text { ADMINISTRATIVO } \\
\text { E FINANCEIRO }\end{array}$ & $60,9 \%$ & $39,1 \%$ \\
\hline $\begin{array}{r}\text { MARKETING } \\
\text { E VENDAS }\end{array}$ & $64 \%$ & $36 \%$ \\
\hline $\begin{array}{r}\text { OUTRAS } \\
\text { AREAS }\end{array}$ & $57,2 \%$ & $42,8 \%$ \\
\hline & & \\
\hline
\end{tabular}

Fonte: II Censo da IBJD (2018)

Figura 26: $2^{\circ}$ Censo da Indústria Brasileira de Jogos Digitais (2018) 
A distribuição de gênero trata-se de uma discussão absolutamente relevante uma vez que "alguns autores acreditam que o fato de haver predominância masculina entre os desenvolvedores de jogos pode trazer distorções na forma como os jogos são concebidos" (SAKUDA, 2018, p.144), especialmente na propagação de estereótipos femininos.

Acentuam algumas possíveis explicações para o baixo número de mulheres presente nessa indústria, tais como:

Sexismo nos jogos online (assédio e agressão), o que resulta em falta de interesse pelos jogos; falta de incentivo para carreiras de tecnologia; o fato de que videogames são socialmente vistos como artefatos masculinos; e a forma de organização do trabalho (jornadas extensas, picos de trabalho no final do projeto, remuneração instável etc.) que em geral podem ser incompatíveis com as funções de maternagem, ainda atribuídas prioritariamente às mulheres. (SAKUDA, 2018, p.146)

Em um artigo na revista Wired, Lacour (2017) relata sobre a falta de representatividade das mulheres engenheiras no Vale do Silício, essas que ao falarem sobre seus ambientes de trabalho destacam que "muitas vezes são as únicas mulheres em suas equipes e devem reafirmar constantemente suas habilidades e conhecimentos. Elas veem poucos modelos de inspiração ou caminhos para avançar" (LACOUR, 2017 - tradução nossa). Claro que não é um movimento exclusivo da área de desenvolvimento de games, as mulheres em tantas outras áreas ainda precisar lutar por seus direitos, legitimidade e reconhecimento.

Quanto à constatação do perfil do consumidor brasileiro relativamente à tecnologia, concluíram que:

Vale notar que os aparelhos móveis estão presentes de maneira ampla em todas as classes sociais, diferentemente dos computadores e dos consoles, cuja utilização é concentrada principalmente para pessoas das classes A e B. De acordo com a pesquisa TIC Domicílios 2016, 93\% das residências brasileiras têm pelo menos um aparelho de celular. Em comparação, os percentuais para computadores ficam em patamares bem inferiores: apenas $29 \%$ dos lares têm um notebook, $22 \%$ têm um computador de mesa e $18 \%$ têm um aparelho de console. No entanto, os percentuais para residências com computadores de pessoas das classes A e B são significativamente maiores. Os consoles estão presentes em $53 \%$ dos domicílios na classe A e em $36 \%$ na classe B. Da mesma forma, $68 \%$ das residências de pessoas da classe A possuem pelo menos um computador de mesa, e $94 \%$ dos 
domicílios da classe A têm notebooks. Nos lares de pessoas da classe B, $50 \%$ tem pelo menos um computador de mesa, e em $72 \%$ deles têm notebooks. (SAKUDA, p.146, 2018)

Reiterando novamente a importância da mobilidade dentro da indústria dos jogos, nacional e internacionalmente, de forma a entender que a aceitação do smartphone como plataforma favorita é principalmente pela facilidade e praticidade de já estar com o dispositivo e a grande oferta de jogos que não tem custo algum.

A pesquisa da Newzoo, de 2019, segmentou oito perfis de possíveis jogadores consumidores a nível mundial, nos quais são resumidos por: jogadores pipoca (não jogam muito, mas adoram assistir a conteúdos gamers e de $e$-sports), jogadores cloud (gostam de jogos de alta qualidade com experiência), jogadores espectadores do banco traseiro (assistem ao conteúdo de vídeo ou e-sports, mas raramente jogam, costumavam ser jogadores assíduos, porém já não tem mais tempo), jogadores ultimate (vivem e respiram os jogos em todos os aspectos do mercado, em computadores e gadgets), jogador entusiasta completo (também são jogadores ávidos, jogando muitas horas por semana) jogador convencional (como o jogador ultimate só que de dez anos atrás antes da ascensão meteórica dos e-sports), o jogador time fillers (joga no celular para passar o tempo, não percebem jogos como forma importante das suas vidas), e por fim, o jogador entusiasta de hardware (vital para a experiência deles, investem muito em equipamentos e periféricos, amor por eletrônicos vai além dos jogos) (Global Games Market Report 2019, p. 25, 2019 - tradução nossa).

Em mais uma pesquisa realizada dentro do contexto de análise do mercado de videogames, a Pesquisa Game Brasil $2018^{23}$ (PGB 2018) realizada em parceria pela Sioux Group, Blend New Research, ESPM e Go Gamers, relatou em seus dados que os dispositivos móveis são as plataformas mais utilizadas e que os consumidores são pouco fiéis:

O smartphone se consolidou como plataforma principal de consumo de jogos digitais. Apesar de não ser reconhecida pelos jogadores como a plataforma com os melhores gráficos, melhor imagem ou maior controle (características estas mais votadas em relação aos consoles e

23 Disponível em: https://rdstationstatic.s3.amazonaws.com/cms\%2Ffiles\%2F62186\%2F1556825231PGB_2018_Painel.pdf?utm_campaign $=$ material_2018\&utm_medium=email\&utm_source=RD+Station. Acesso em 16 de mar. de 2020 . 
computadores), a possibilidade de jogar a qualquer instante do dia e ter o aparelho sempre à mão são fatores determinantes para o hábito dos jogos digitais estarem mais presentes na sociedade. Os jogos digitais são os aplicativos mais baixados pelos consumidores nessa plataforma. No entanto, por baixarem muitos jogos gratuitos, acreditamos que o giro de jogos no aparelho é alto. Em outras palavras, o consumidor tende a ser pouco fiel, com poucas exceções. Isso é reforçado pelo fato do jogador dizer que os anúncios publicitários dentro dos jogos atrapalha a experiência, mas baixam o jogo de qualquer maneira. Ou seja, a inconveniência da publicidade no jogo não é tão ruim quanto a inconveniência do custo do jogo. Uma noção curiosa do senso comum, já que o custo médio de outros tipos de entretenimento tendem a ser maiores do que a aquisição de um jogo digital, e com aproveitamento de tempo menor, como uma ida ao cinema, jantar no restaurante, aluguel de uma quadra de futebol etc.. Isso nos faz levantar a hipótese que o problema não está no preço dos jogos digitais, mas na noção de valor que o consumidor tem sobre o jogo ofertado. Com o excesso de ofertas nas lojas digitais, somada a baixa diferenciação percebida dos jogos pagos, o jogador se contenta com as ofertas gratuitas e com publicidade. (PGB, 2018, p. 70)

Há também uma grande mescla entre online e offline (retomando, portanto, o conceito da onlife), sobre como as relações com os games ganham dimensões mercadológicas como o grande investimento nos e-sports que desde 2016 começaram a ter grande audiência e exibição ao vivo, tal como outros esportes. Além disso, também consomem e alimentam conteúdos relacionados aos jogos, buscando conhecimento e dicas em grupos do Facebook, canais do YouTube e nos sites dos jogos, sendo o inglês a língua mais utilizada.

Sobre o perfil do jogador:

A divisão gamer e não-gamer não implica em maior consumo de jogos, ou maiores gastos com esse tipo de entretenimento. $\mathrm{O}$ que podemos esperar é que o gamer é mais envolvido com o consumo simbólico dos jogos, provavelmente se localizando entre os heavy users de um determinado jogo, colecionando objetos das marcas que segue e participando de comunidades relacionadas. (PGB, 2018, p. 69)

Na pesquisa "Mundo invisível dos games" realizada pela Talk Ink ${ }^{24}$ em 2017 utilizaram a metodologia de entrevista a 1.215 jogadores e mapearam que a maior concentração etária de jogadores é na faixa de 21 a 30 anos, além disso novamente se pontua que mais jogam no smartphone e com categorias variadas, tais como percebidas no gráfico abaixo:

24 Disponível em http://gamers.talkdigital.co/wp-content/uploads/2017/09/O-mundo-invisivel-dosgamers.pdf. Acesso em: 02/07/2020. 


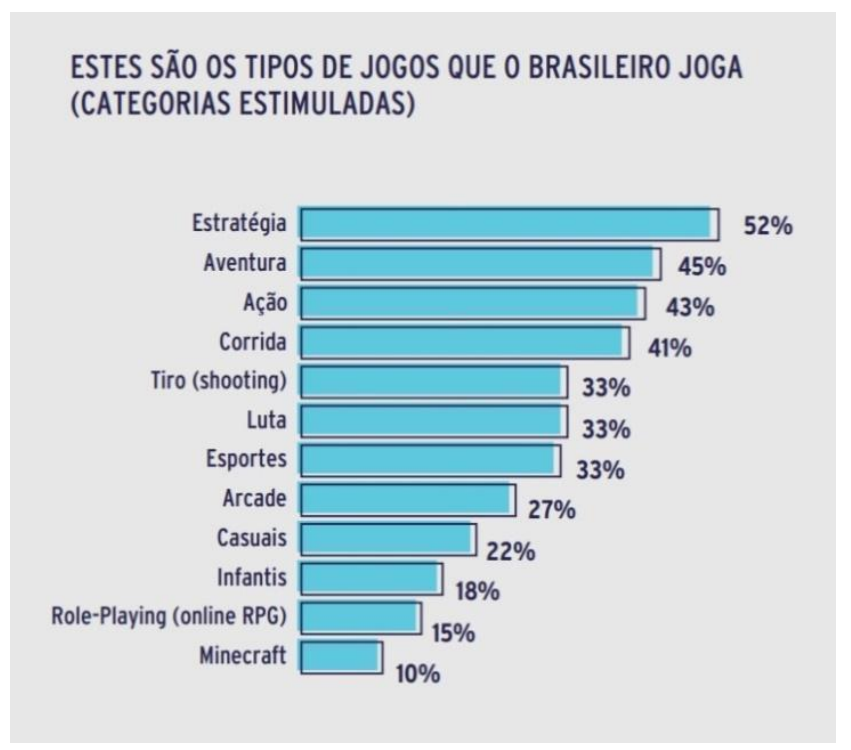

Figura 27: O mundo invisível dos games pela Talk Ink (p.18, 2017)

Há também a confirmação do grande investimento de tempo para além do despendido enquanto jogando, como se percebe abaixo:

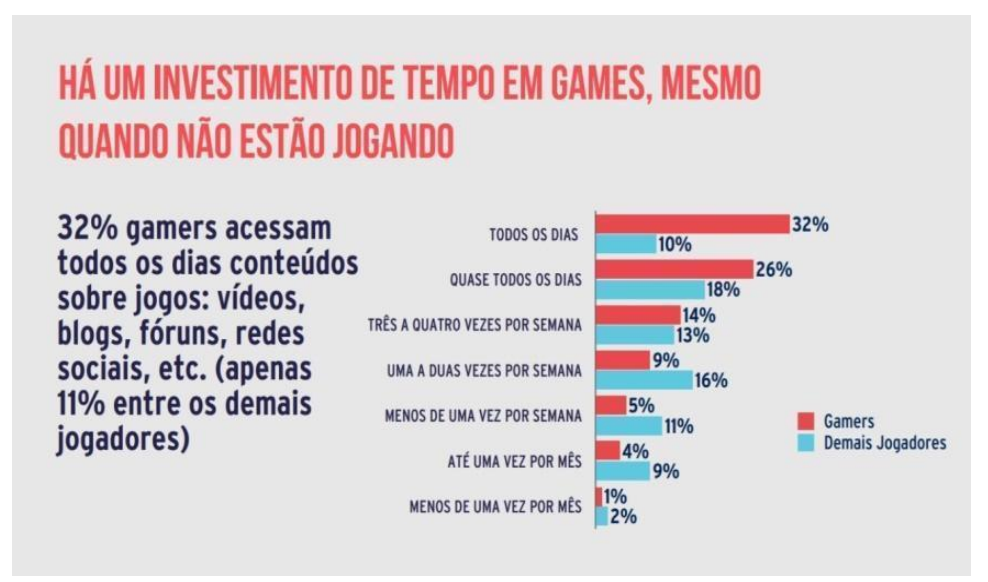

Figura 28: O mundo invisível dos games pela Talk Ink (p.88, 2017)

Diferenciam o perfil de um jogador em até 3 horas semanais para um gamer, classificados como um sujeito que joga mais do que dez horas semanais, que seria pela definição da Newzoo os jogadores ultimate e os entusiastas completos. Assim, no caso do jogo Pokémon GO dispendem diariamente uma média de quarenta minutos e se diferenciam dos jogadores entusiastas completos pelo nível de complexidade estratégica 
que esses jogadores solicitam, além do mais é um público mais amplo, desde crianças até idosos que utilizam o jogo como o perfil de time fillers.

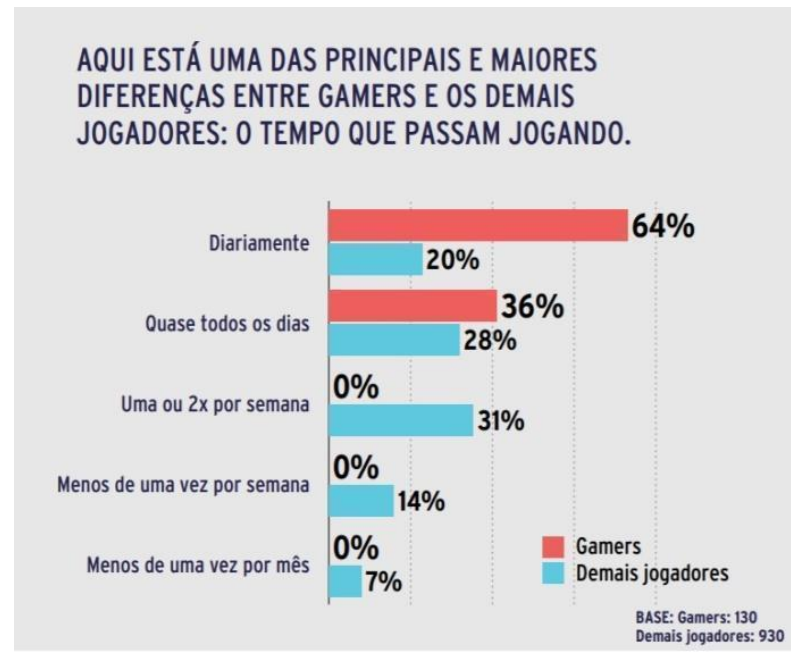

Figura 29: O mundo invisível dos games pela Talk Ink (p.27, 2017)

Um fator em comum entre os entrevistados pela Talk Ink é a sensação de pertencimento e propósito diante de uma comunidade, como será abordado mais à frente na análise do Pokémon GO. Destacaram também o aspecto negativo sentido por estes, de como geralmente há um tipo de preconceito com quem é gamer, de que são infantis, que perdem tempo demais online, que são viciados e que tem dificuldades sociais.

Também não acreditam serem motivados apenas pelo entretenimento: "o que motiva a jogar envolve outros fatores como o desafio, a competição e a socialização. Jogar não é só diversão. É estratégia, desafio, imersão em uma história e fazer amigos" (Talk Ink, 2017, p.50). O que leva para outro fator que seria a complexidade e em como conforme há maior complexidade e estratégia, há maior envolvimento e imersão, que geralmente são mais elaborados nos videogames de console comparativamente com os de smartphones.

Novamente há o preconceito mais evidente contra as mulheres gamers que muitas vezes optam por escolher um avatar e nome neutro para não serem assediadas, o que dá a percepção que há menos mulheres jogando do que o número real. 
Escapismo do chamado mundo real também é um fator em comum entre os gamers, entendido como uma segunda vida na qual podem controlar e se sair melhor do que em outros aspectos da própria vida.

Foram cruzados os dados coletados entre a $19^{\text {a }}$ Pesquisa Global de Entretenimento e Mídia (Global Entertainment \& Media Outlook 2018-2022) pela PwC, a Global Games Market Report da Newzoo, o $2^{\circ}$ Censo da Indústria Brasileira de Jogos Digitais pelo Ministério da Cultura (MinC) e a Organização das Nações Unidas para a Educação, a Ciência e a Cultura (Unesco), a Pesquisa Game Brasil 2018 (PGB 2018) pela Sioux Group, Blend New Research, ESPM e Go Gamers e a pesquisa Mundo invisível dos games realizada pela Talk Ink.

Muitos aspectos convergem para dados similares que em súmula são: uma construção de perfis dos jogadores relativamente às motivações e ao investimento de tempo nos videogames, a importância da conectividade ininterrupta, como os videogames das décadas de 1980 e 1990 voltam com uma valorização da nostalgia retomando uma relação anterior com alguns jogadores, o quanto é crucial o desenvolvimento da estratégia e da complexificação conforme o avanço no videogame, o alto investimento em gameficação, a grande diferença de gênero dentro desse contexto e preconceito contra mulheres gamers, como algumas tecnologias são consideradas essenciais e em ascensão como os robôs, a internet das coisas, a realidade aumentada e a realidade virtual, como existe uma criação de fóruns, vídeos e produtos para além do universo dos videogames e principalmente como a utilização do smartphone é o maior segmento de investimento.

Construído esse breve panorama é possível examinar com um olhar mais direcionado o caso do jogo Pokémon GO.

\section{2) Caso Pokémon Go}

O foco é acerca dos videogames especificamente que se utilizam da linguagem realidade aumentada em dispositivos móveis e em como isso altera a relação do jogador com o jogo. 
Entendeu-se como necessário a realização de uma análise mais pontual sobre o fenômeno que causou histeria mundo afora, o aplicativo do jogo Pokémon GO, lançado em julho de 2016 pela empresa Niantic. Ingress foi uma experiência anterior da Niantic, com um jogo que propunha que os jogadores buscassem portais pela cidade, essa com um ambiente estético bastante futurista e foi importante por lançar as bases para o que seria o Pokémon GO.

A empresa Niantic começou no ano de 2010, mas apenas obteve reconhecimento mundial com a realização da parceria com a Nintendo e a Pokémon Company. A

Sensor Tower trabalha com inteligência e métricas econômicas de aplicativos no intuito de prover estratégias nas decisões aos desenvolvedores e fornecem informações sobre o crescimento e qualidade, como informações de número de downloads, receita das empresas e notas atribuídas a partir de um ranking deles. De acordo com dados sobre o aplicativo Pokémon GO, em abril de 2020, demonstram que o aplicativo do jogo é absolutamente rentável com mais de três milhões de downloads, recebendo a maior nota atribuída pelo site, sendo A+.

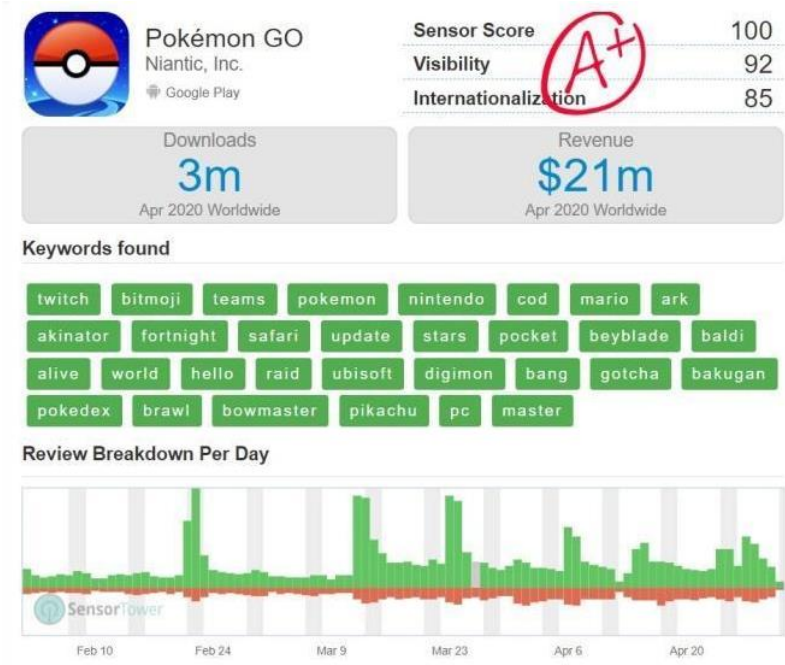

Figura 30: Sensor Tower ${ }^{25}$ - Abril de 2020 em busca sobre "Data That Drives App Growth"

Entretanto, em outros rankings no mês de março de $2020^{26}$, o aplicativo não aparece nem entre os mais solicitados entre as lojas dos sistemas da Apple e Android, o que pode ser principalmente atribuído pelo novo lançamento que é a diversificação na

\footnotetext{
${ }^{25}$ Disponível em: https://sensortower.com/. Acesso em 20 de abril de 2020.

${ }^{26}$ Disponível em: https://sensortower.com/blog/top-mobile-games-worldwide-march-2020-by-downloads. Acesso em 20 de abril de 2020.
} 
utilização das plataformas com um retorno aos videogames para além dos smartphones e tablets, mesmo que sejam móveis também, como é o caso do Nintendo Switch, que possui a dupla funcionalidade, de ser móvel e também console ligado à televisão.

O jogo chama-se Pokémon Home, foi lançado no dia 12 de fevereiro de 2020, é do modelo de RPG (role playing game) traduzido para jogo de interpretação de papéis e teve na sua primeira semana de disponibilidade mais de 1,3 milhões de instalações.

No entanto, não é possível entender que o aplicativo do jogo deixou de ser relevante, pelo contrário, ainda é uma das frentes de ação da empresa e estimula a rotatividade da receita juntamente com venda de produtos do universo, tais como pelúcias, roupas, cards, livros, bonecos, quadros e artefatos para casa. Além do fato de 2019 ter sido seu ano mais lucrativo desde o lançamento em 2016, gerando em média o gasto de 894 milhões de dólares em gastos brutos com jogadores, apresentando uma baixa em 2017 apenas, como apresentado no gráfico:

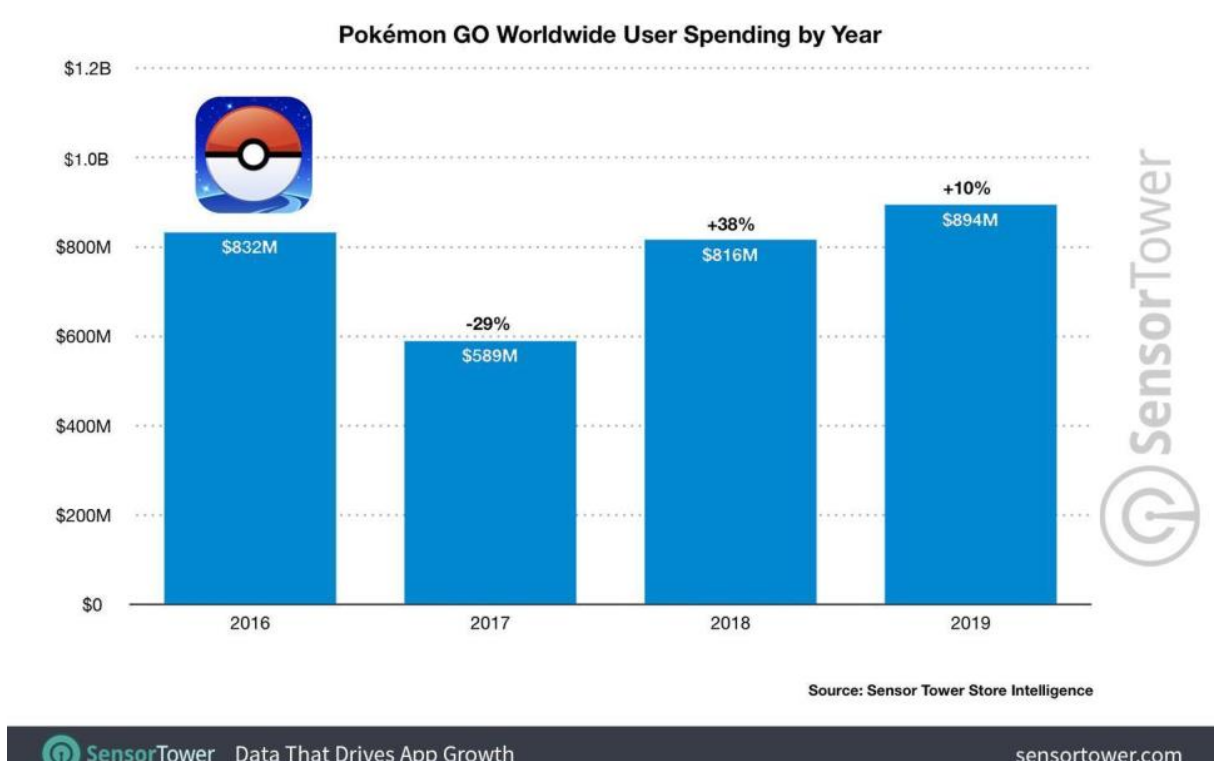

Figura 31: Sensor Tower - Gasto anual no jogo Pokémon GO

O que destacamos aqui é a sua importância como fator de democratização e acessibilidade à linguagem da realidade aumentada em que o jogo junta o aumento digital com a internet das coisas na utilização do smartphone e isso de fato é inédito.

Zsila et al (2018) aponta que a franquia Pokémon foi originalmente criado por um designer de videogame japonês, Satoshi Tajiri, em meados da década de 1990 
quando desenvolveu videogames para os dispositivos Game Boy da Nintendo, “introduzindo o mundo aos Pocket Monsters (monstros de bolso), no qual os jogadores estão instruídos a coletar todas as espécies de Pokémon que encontrarem em cidades virtuais" (ZSILA et al, p. 56, 2018- tradução nossa).

Na década de 2000 a história foi adaptada a uma série de anime e se tornou altamente popular fora do Japão. O universo da franquia "Pokémon expandiu-se rapidamente com filmes, quadrinhos, cartas para trocar, brinquedos e outras produções que foram fabricados como parte da sensação da mídia global Gotta Catch 'Em All (tenho que pegar todos)" (ZSILA et al, p. 57, 2018 - tradução nossa). Momento esse que foi retomado pela Niantic em propagandas que se valem da nostalgia.

De acordo com a descrição do aplicativo disponível juntamente com o download, se trata de:

\begin{abstract}
Viaje entre o mundo real e o mundo virtual de Pokémon com Pokémon GO, para iPhone e dispositivos Android. Com Pokémon GO, você descobrirá Pokémon em um mundo completamente novo, o seu mundo! Pokémon GO permite que você explore lugares reais e procure por Pokémon mundo afora. Mais e mais Pokémons continuam a aparecer por todo o mundo, incluindo Pokémon Lendários raros e poderosos. Ao caminhar pelos lugares onde você mora e visita, seu smartphone pode vibrar para alertá-lo de que há um Pokémon por perto. Quando tiver encontrado o Pokémon, mire bem na tela do seu smartphone e jogue uma Pokébola para pegá-lo. Mas cuidado, porque ele pode fugir! Procure também por Poképaradas em lugares interessantes, como instalações de arte públicas, marcos históricos e monumentos, onde você poderá coletar mais Pokébolas e outros itens. $^{27}$
\end{abstract}

O funcionamento do jogo é bastante intuitivo, consiste basicamente em procurar com a câmera os pokémons e tentar pegá-los com o movimento da pokébola, que se realiza ao passar o dedo na tela apontando para o círculo que aparece sobre a cabeça do desenho do Pokémon.

Há variações de acordo com o nível de dificuldade da captura, e assim que acerta o círculo, o Pokémon é incorporado à conta do usuário. É a partir do nível cinco que o jogador pode acessar espaços de batalha e espaços chamados de academia para

\footnotetext{
${ }^{27}$ Disponível em: <https://www.pokemon.com/br/app/pokemon-go>. Acesso em 20 de nov. de 2020
} 
aprender a batalhar contra outros jogadores, além de poder estudar estratégias e discutir movimentos com outros jogadores.

Assim, o jogo começa mais simples e conforme vai evoluindo, ao avançar nos níveis, vai se tornando mais complexo e criando mais camadas de envolvimento para os jogadores.

Parece-nos interessante investigar os motivos para tamanho sucesso, tais como remeter a certa nostalgia da década de noventa com a retomada de um desenho e todo um universo que fez parte da infância e adolescência de milhões de jovens; por ser inteiro em realidade aumentada e isso ser um fator de novidade relativamente a jogos em smartphones e tablets; outro fator também é por ser download gratuito e também por oferecer uma mescla entre espaços físicos reais e o universo do jogo.

Phingbodhipakkiya (2016) entende que um dos fatores de sucesso vem do funcionamento neural, uma vez que o cérebro humano é bastante responsivo ao movimento, e o jogo nesse sentido é bastante estimulante, "nossos cérebros adoram novidades, e o mesmo caminho de recompensa dopaminérgico que é acessado quando falamos sobre nós mesmos também é ativado quando experimentamos coisas novas" (PHINGBODHIPAKKIYA, 2016, n.p. - tradução nossa). Ou seja, há uma ativação que acontece no cérebro do jogador que o faz repetir a ação para obter mais recompensas, "no caso do Pokémon GO, você está experimentando coisas novas toda vez que joga o jogo - e isso leva você a ir para novos locais, para encontrar novos Pokémons" (PHINGBODHIPAKKIYA, 2016, n.p. - tradução nossa).

Para a pesquisadora, as respostas virtuais ativam exatamente as mesmas redes neurais do que seria uma experiência real, "as imagens de recompensas e recompensas reais são percebidas quase de forma idêntica no cérebro. O Pokémon GO pega pistas do ambiente real e as une ao mundo virtual para obter maior impacto" (PHINGBODHIPAKKIYA, 2016, n.p. - tradução nossa).

Flores e Herrera (2019) elencaram fatores de êxito do jogo destacando também a nostalgia, download gratuito, atualizações contínuas, dinâmica de jogos e implementação sólida de micro pagamentos além do maior diferencial que é incitar a saída para o mundo real em busca da diversidade a ser capturada: 
A loucura de PG chegou a tal ponto que o caminho percorrido por seus jogadores excedeu a distância entre a Terra e Plutão (Butcher, Sung e Raynes-Goldie, 2018). Levando a internet para qualquer lugar usando smartphones e permite que os usuários do PG vejam as cidades como uma mesa gigante que pode ser conquistada. (FLORES, HERRERA, p. 322, 2019 - tradução nossa)

A estratégia multimídia criada para além do jogo é também um fator de sucesso, talvez a mais intricada uma vez que toda uma rede ao redor foi desenvolvida, tanto fornecida oficialmente pela empresa Niantic como canais no YouTube e páginas no Facebook, como também pelos jogadores que criaram páginas de suporte com troca de informações e tutoriais com os mais diversos objetivos, como dicas para encontrar pokémons, áreas de interesse, métodos de captura, estratégias de batalhas, entre outros.

Refletindo sobre as estratégias comerciais do jogo Flores e Herrera entendem que:

Num mundo cada vez mais global, as estratégias devem ser dinâmicas para se adaptar a quaisquer mudanças imprevistas. Não é possível considerar o sucesso nos negócios sem detectar ou tenha uma boa ideia dos motivadores que conduzirão a uma compra do cliente. Descobrir o que torna a aplicação eletrônica popular é crucial. (FLORES, HERRERA, p. 323, 2019 - tradução nossa)

De forma que existe toda uma estratégia que vai muito além da interação jogador com a interface, na qual as empresas:

Devem ser totalmente ciente dos motivos que motivam ou impulsionam o download de aplicativos eletrônicos pelos usuários e, acima de tudo, em como retê-los para a geração receita contínua para a organização que alimenta as vantagens competitivas capaz de prevalecer sobre os contra-ataques de adversários comerciais. (FLORES, HERRERA, p. 324, 2019 - tradução nossa)

Cacchione, Legg e Petersen (2017) destacam alguns outros fatores para a qualidade do jogo Pokémon GO:

Em primeiro lugar, o jogo é lindo: os ambientes são coloridos, detalhados, curados graficamente. A impressão geral é quase o de um espaço 3D. A identidade do usuário é personalizável e você pode escolher como deseja aparecer o jogo (nome, cabelo, olhos, roupa). A trilha sonora é boa e existem bons efeitos sonoros para comandos também. (CACCHIONE, LEGG, PETERSEN, p. 26, 2017 - tradução nossa) 
Porém o que de fato é o seu maior diferencial, para os autores, é o que denominam de fator de atividade, de que para que o jogo seja funcional é necessário que o jogador precise andar, ou seja, não é um jogo que pode ser jogado apenas enquanto estiver deitado no sofá, é necessária uma ativação vinda do jogador:

\begin{abstract}
Ninguém mais pode pegar um Pokémon para você - você tem que agir. Isso lhe dá uma razão para sair para passear - houve notícias de pessoas perdendo uma quantidade significativa de peso jogando. Também fornece um motivo para conversar com outras pessoas que você talvez não conhecesse: dar e receber dicas, saber como vencer os mais fortes ou saber onde estão os Pokestops mais próximos. Pokestops são pontos-chave para socializar. São locais especiais de interesse - monumentos, estátuas, portais etc. - e onde você pode obter pokébolas e outras ferramentas úteis. Também são por geolocalização como todo o resto, e liberam suas ferramentas somente quando você estiver perto o suficiente delas. (CACCHIONE, LEGG, PETERSEN, p. 26, 2017 - tradução nossa)
\end{abstract}

Percebe-se o alto investimento da Niantic tanto em marketing quanto em desenvolvimento do jogo no intuito de que os jogadores não percam interesse em longo prazo, uma vez que, apesar de ir passando de níveis, o jogo ainda consiste na captura dos pokémons, por isso as estratégias de batalhas e de treinamentos.

Além disso, propõem uma experiência imersiva que vem a partir das músicas, da linguagem coloquial e de toda a criação visual de um universo que articula o aspecto competitivo advindo dos games com a memória afetiva do desenho. Assim, a utilização da abordagem pela linguagem da realidade aumentada ampliou os efeitos em um novo plano.

Uma questão bastante preocupante diz respeito aos possíveis problemas de segurança por conta do jogo, de forma que a Niantic se posicionou fornecendo alguns avisos e orientações úteis. Isso ocorreu como uma resposta a uma crise desencadeada por alguns jogadores que se acidentarem ao não prestarem atenção ao ambiente real ao redor por estarem muito focados em nas ações virtuais. Infelizmente se envolverem em acidentes de carros, serem assaltados ou caíram e tropeçarem, alguns de forma mais leve e outros mais gravemente.

Há no aplicativo do jogo alguns avisos que alertam sobre não jogar enquanto dirige e para olhar para o caminho onde anda. 


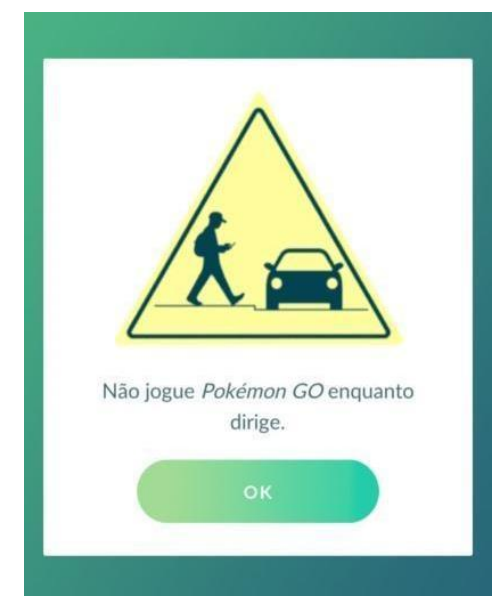

Figura 32: Print screen do jogo no smartphone

Crary (2013) sugere que a percepção está suspensa:

Que nossas vidas sejam tão inteiramente uma colcha de retalhos de tais estados desconexos, não é uma condição natural e sim, o produto de uma densa e poderosa recomposição da subjetividade humana no ocidente ao longo dos últimos 150 anos. Tampouco é insignificante o fato de que no fim do século XX uma imensa crise social de desintegração da subjetividade seja metaforicamente diagnosticada como déficit de "atenção". A percepção se caracteriza fundamentalmente por experiências de fragmentação, choque e dispersão. (CRARY, 2013, p. 25)

Assim, entendendo que a percepção estética está ligada estritamente aos processos históricos, com a contemporaneidade a atenção se torna um problema central, de forma que com as mudanças sociais e econômicas culmina-se em uma reorganização radical da cultura visual e auditiva. Por isso ocorrem essas fricções como os acidentes envolvendo os jogadores dado que ainda é uma experiência em processo de adaptação.

Coloca deste modo que a atenção não é algo individual e sim um problema atual e moderno, de forma que conseguimos entender a divisão da atenção ao jogar um jogo no celular:

É importante enfatizar que essa profunda reconstrução social do observador no século XIX partiu da suposição geral de que era impossível pensar a percepção em termos de imediatismo, presença ou interrupção. É apenas que a percepção funcione de tal modo a garantir que um sujeito seja produtivo, controlável, previsível, que seja adaptável e capaz de integrar-se socialmente. (CRARY, 2013, p. 29) 
A mente do jogador/usuário acaba por estar dividida entre o ambiente real e o virtual, que está projetado em um smartphone, e por isso pode se concentrar na tela e não perceber um perigo no mundo real. Ou seja, trata-se de uma questão sobre atenção e cognição em como isso se realiza na área neural dos jogadores. Abaixo, um exemplo de como os pokémons virtuais estão inseridos na realidade.

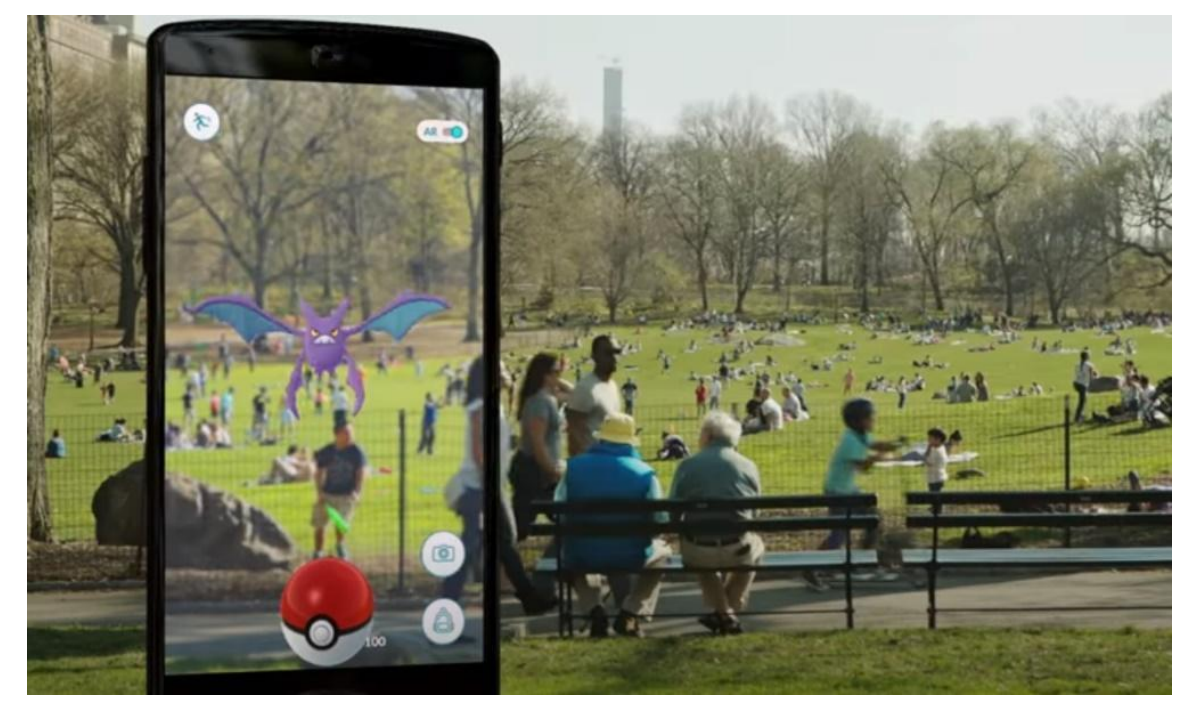

Figura 33: Canal Oficial Pokémon no YouTube

Sobre a atenção, Palaus et al (2018) afirma:

Recursos de atenção são um dos principais domínios cognitivos em que os videogames estão envolvidos e um dos mais pesquisados. $\mathrm{O}$ envolvimento de redes atencionais durante o jogo é intimamente relacionado com outras regiões do cérebro responsáveis pela cognição especialmente quando operações mais complexas em direção a objetivo específico é necessário. Muitas regiões do cérebro estão envolvidas em atenção, particularmente nós no sistema frontoparietal dorsal, mediação de processos atencionais de cima para baixo em comportamento, mas também nos nós da rede ventral, responsáveis para estimulação sensorial de baixo para cima lidar com os estímulos salientes aos quais o jogador deve prestar atenção. (PALAUS et al, p. 28, 2017 - tradução nossa)

Em uma entrevista na coluna Datacracia da rádio USP, Radfahrer (2019) comenta sobre como os dispositivos influenciam na percepção que o indivíduo tem sobre a realidade, o qual nomeia de realidade digital, essa que converge inúmeras tecnologias como a aumentada, virtual, mista, internet das coisas e interfaces ambientais. 
Assim, afirma que há um apoio nessa prótese digital que é o smartphone e como isso influência a quantidade de informações que somos capazes de armazenar e que passamos a enxergar a realidade através dela, "você se torna ao mesmo tempo mais forte e mais expansivo, porque você tem membros artificiais e por outro lado também muito mais dependente" (RADFAHRER, 2019, n.p.).

Essa relação de fortalecimento e dependência se aplica à atenção dividida dedicada ao jogo uma vez que se potencializa a cognição e por outro lado prejudica a atenção ao mundo real.

Buscar as motivações e os engajamentos dos jogadores/usuários também tem sido um foco de pesquisa quando se trata do estudo dos videogames, tanto que "o processo de iniciar, dirigir e manter atividades físicas e psicológicas; inclui mecanismos envolvidos nas preferências de uma atividade em detrimento de outra e o vigor e persistência das respostas" (Gerrig, Zimbardo, Campbell, Cumming, \& Wilkes, p. 409, 2010 - tradução nossa).

Portanto, especificamente sobre Pokémon GO em uma pesquisa realizada na Hungria, relatou-se que:

Recreação, atividade ao ar livre, nostalgia e fuga do tédio foram
encontrados como as principais motivações para os jogadores. Embora
os resultados sugiram que a motivação dos jogadores Pokémon GO
diminuiu em múltiplos aspectos, os motivos de competição e
desenvolvimento de habilidades, bem como a necessidade de
recreação aumentaram. (ZSILA et al, p. 65,2018 - tradução nossa)

O engajamento e envolvimento para além do tempo jogando é perceptível em extensas comunidades online, como no Facebook, em blogs e no canal oficial do YouTube, com mais de três milhões de inscritos, em que há trocas de informações, dicas e truques para os jogadores. Esses buscam aperfeiçoar suas habilidades dentro do jogo e para Gee (2005) "as pessoas aprendem e praticam melhor as habilidades quando veem um conjunto de habilidades relacionadas como uma estratégia para alcançar objetivos que desejam" (GEE, 2005, p. 22 - tradução nossa) de forma que em jogos que o autor classifica como bons, os jogadores aprendem habilidades como parte de realizar o que precisam e desejam realizar: "eles veem as habilidades principalmente como estratégia para atingir uma meta e apenas secundariamente como um conjunto de habilidades" (GEE, 2005, p. 22 - tradução nossa). 
Ao acompanhar essas trocas de informações se percebe que são das mais variadas possíveis, das quais destacamos:

- ensinar a forma como girar o dedo na tela do celular para que a pokébola faça uma curva correta no momento do arremesso e, portanto, consiga capturar o Pokémon;

- não basta capturar o Pokémon, há métodos de arremessar que são mais estratégicos e, assim, se ganham pontos de experiência até se tornar um nível chamado de excelente;

- é possível ativar a função da câmera colocando o Pokémon dentro do ambiente real ao qual a câmera esta apontada e registrar o momento;

- os pokémons são divididos em níveis de facilidade na captura, vão dos mais fáceis, os verdes, para amarelos com dificuldade média e os vermelhos que são mais difíceis e necessitam pokébolas especiais;

- As pokébolas especiais são adquiridas conforme o jogador vai avançando nos níveis de forma gratuita ou podem ser compradas a partir do dinheiro do jogo, os chamados pokecoins;

- o número de capturas é importante mesmo que sejam personagens já repetidos, isso pontua ao jogador e este pode trocar por itens especiais que podem transformar os pokémons capturados em mais evoluídos;

- além da importância da captura o jogador chamado de treinador dentro do universo, também tem itens específicos que podem aumentar as forças de combate dos pokémons, o que os torna mais potentes nas disputas com outros jogadores;

Abaixo o exemplo de como são visualmente esses elementos descritos acima: 


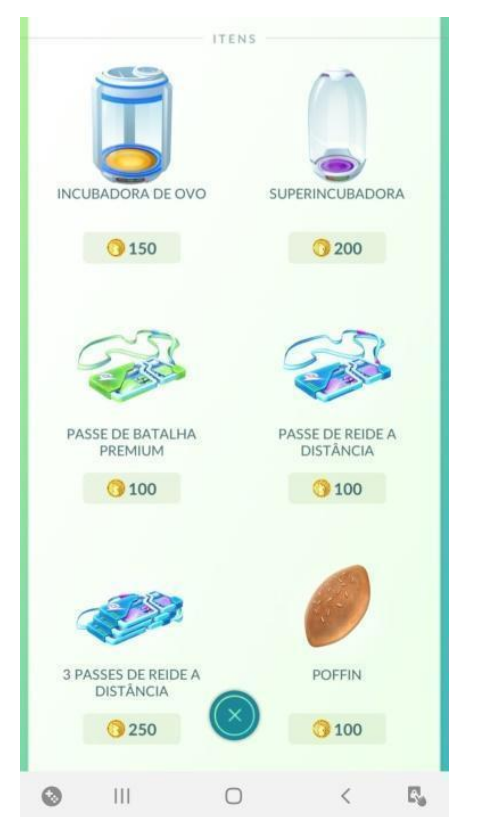

Figura 34: Print screen do jogo no smartphone

- outra questão importante é como o jogador precisa andar para ativar o jogo, quanto mais se anda mais resultados se encontra, uma dica encontrada nas comunidades é de evitar trajetos com muitos obstáculos, haja vista que a geolocalização do jogo funciona por quilometragem e ao andar de forma mais reta a contabilização é mais efetiva;

- relacionando com a quilometragem, quanto mais andam mais se podem eclodir os chamados ovos, esses que vão sendo recebidos conforme os níveis vão aumentando;

- há tipos diferentes de pokémons e as localizações interferem em sua captura, por exemplo, os aquáticos ficam próximos de rios, mares ou piscinas, os terrestres em ambientes com terra, os insetos em ambientes de jardins e os fantasmas em lugares ermos e a noite, a lista é bastante extensa uma vez que existem muitos tipos, com exemplos a seguir; 


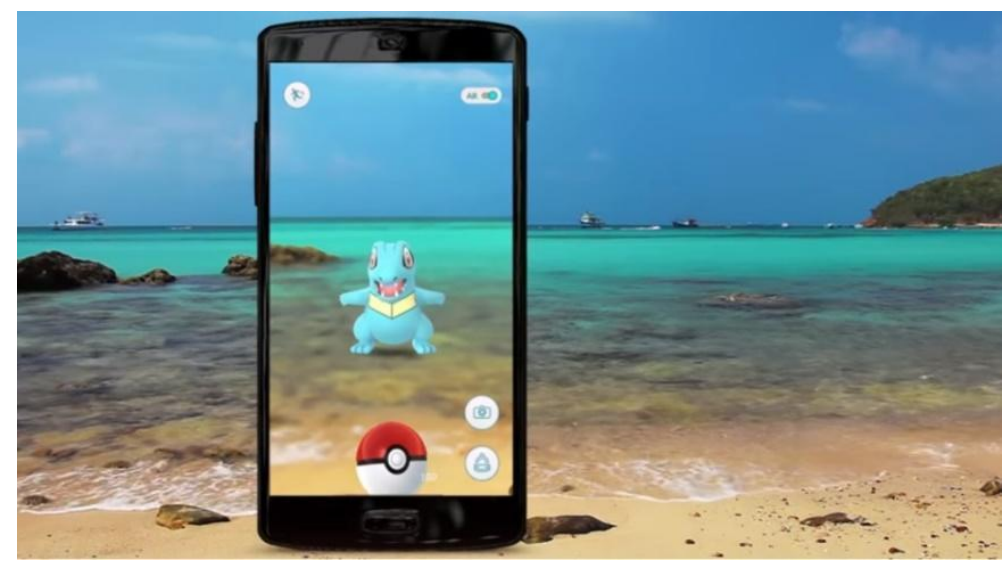

Figura 35: Canal Oficial Pokémon no YouTube ${ }^{28}$ vídeo The World of Pokémon GO has Expanded

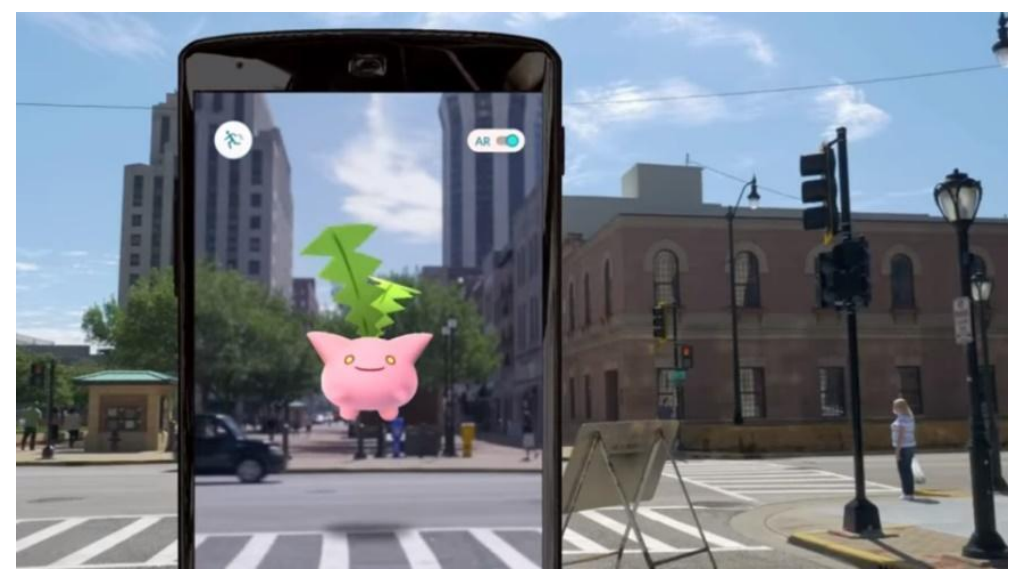

Figura 36: Canal Oficial Pokémon no YouTube vídeo The World of Pokémon GO has Expandedo

- cada Pokémon leva em consideração como era no desenho e nos jogos anteriores, tem um gênero, uma fraqueza e uma força, esse estudo de cada um permite que o jogador tenha mais chance de vencer nas batalhas com os adversários, quanto maior o $\mathrm{CP}$, nomenclatura para unidade de medida que aponta a força de combate;

Abaixo o exemplo das descrições de cada um dos personagens: 


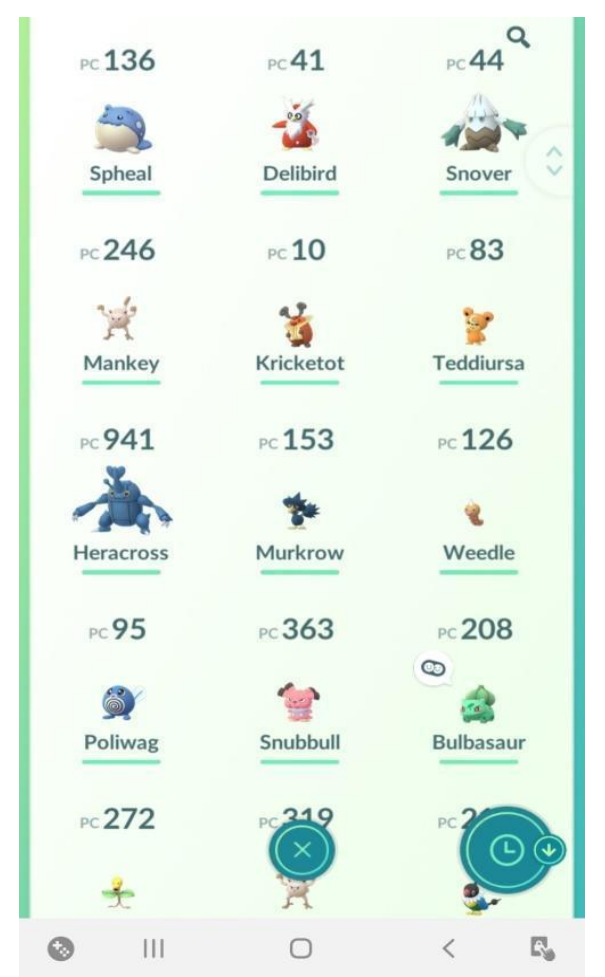

Figura 37: Print screen do jogo no smartphone

- existem ligas de batalhas GO com diversas opções de níveis, como grande liga, ultra liga e liga mestra e há a chamada Copa Premier, que realmente tem estrutura de batalha, como no frame abaixo;

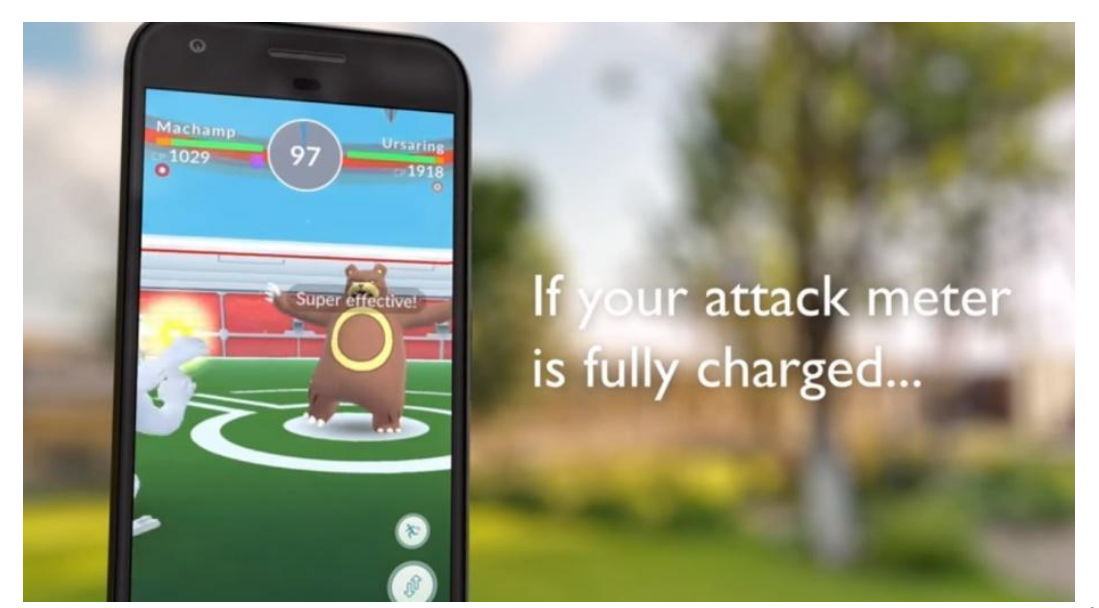

Figura 38: Canal Oficial Pokémon no YouTube Vídeo Advanced Gym Strategy ${ }^{29}$

- é possível adicionar amigos a partir do compartilhamento de um código gerado para cada jogador ou conectar via Facebook, de forma que ao jogar com esses

29 O\&index=3 > Acesso em 13 de out. de 2019. 
contatos há o desbloqueio de trocas, de pokébolas presenteadas e mais poder nas batalhas;

- além dos itens básicos há outros ícones importantes como as poções, que aumentam a vida, as razz berry que são alimentos, os incensos que tem função de atrair, os ovos que dobram a experiência do treinador e os upgrades que aumentam os números de itens que podem ser armazenados.

O jogo cria estratégias de envolver o jogador, criando todo um universo em diversas camadas que vão encantando os interessados, de forma que a empresa Niantic está em constante atualização, criando novas maneiras de manter o frescor do jogo.

Importante ressaltar que devido à pandemia mundial de 2020, houve um posicionamento da empresa ${ }^{30}$ em alterar alguns aspectos básicos do jogo para que os jogadores não necessitem sair de casa para continuar jogando, de forma a manter o isolamento social, mas são mudanças mínimas, tais como aumentar a eficiência temporal dos incensos que tem duração de uma hora quando originalmente duravam apenas trinta minutos e das incubadoras que eram liberadas por quilometragem, assim, a distância foi diminuída pela metade.

O público que joga é bastante variado entre crianças e adolescentes, que se familiarizam rapidamente com a estrutura do jogo e que por vezes se reúnem para a busca dos pokémons. São também mais ativos nas comunidades de troca de informações. No entanto, até adultos e idosos utilizam o jogo para preencher seu tempo.

Relacionando com os dados coletados de pesquisas externas acerca do perfil dos gamers, percebe-se que o Pokémon GO não seria direcionado para esses jogadores assíduos que despendem inúmeras horas semanais nos ambientes virtuais. Isso se deve pela limitação estratégica do jogo que necessita a utilização da localização e do caminhar do usuário, ou seja, existem limitações físicas para a sua realização.

No entanto, em pouco isso interfere no sucesso do jogo que atingiu um número ainda maior do que entre outros games de console, como adolescentes, crianças e adultos que não se interessavam por jogos mais complexos com histórias voltadas para a

\footnotetext{
30 Disponível em: https://g1.globo.com/pop-arte/games/noticia/2020/03/19/pokemon-go-em-casa-comojogar-game-em-tempos-de-quarentena-de-coronavirus.ghtml. Acesso em 13 de abril de 2020.
} 
estratégia e aprofundamento. Além da perspectiva mercadológica que é absurdamente abrangente e vai para além de apenas o ambiente do jogo.

Gee (2005) afirma que bons videogames são os que jogadores fazem as ações acontecerem não apenas repetindo o que os designers do jogo colocaram diante deles, de forma que são interativos e engajam a participação, para o autor isso é a chave para a motivação:

\begin{abstract}
O jogador faz alguma coisa e o jogo faz algo de volta incentivando o jogador a agir novamente. Em bons jogos, os jogadores sentem que suas ações e decisões - e não apenas as ações e decisões dos designers - estão cocriando o mundo em que estão e as experiências que estão tendo. O que o jogador faz importa e cada jogador, com base em sua suas próprias decisões e ações, segue uma trajetória diferente pelo mundo do jogo. (GEE, 2005, p. 5 - tradução nossa)
\end{abstract}

Nesse sentido, Pokémon GO estaria apto a ser um bom jogo, haja vista que a partir do design oferecido, os jogadores vão criando experiências particulares, uma vez que tudo acontece de acordo com o caminho e as escolhas do próprio jogador que marca simbolicamente o seu espaço.

O que se torna bastante único, especificamente no caso de Pokémon GO, é o quanto a plataforma virtual e real permite a criação de uma possibilidade permeável dentro desse virtual, em que o sujeito anda pela cidade, mas não de forma aleatória, seguindo as possibilidades do aplicativo e toma posse desses espaços. Dessa forma, o percurso que o jogador vai realizar pode ser visto como uma forma de escrita e leitura do espaço urbano (LEMOS, 2013, p. 9):

Nesse sentido, a flânerie é um modo de narrativa urbana bem diferente, em sua intenção, da narrativa construída por usuários de sistemas de RA. Aqui o usuário não é um "observador desinteressado" e vai lendo a "floresta de signos" digitais, articulando o seu percurso a partir de intenções bem precisas, objetivas e eficientes (achar o metrô, o café mais próximo, a informação sobre a história de um monumento etc. Andar pelo espaço urbano, seja o flâneur desinteressado, seja o usuário de sistemas de RA, evoca, de uma forma ou de outra, um processo de leitura de símbolos (relação corpo - textura urbana) e de mapeamentos (relação corpo - espacialização) que constituem essa narrativa. Andar pela cidade é (para o flâneur e para o moderno cidadão com serviços de RA) "ler e escrever" o espaço e o tempo deixando rastros (contando uma história). (LEMOS, 2013, p. 9) 
Com a realidade aumentada, o jogador/usuário está lendo e escrevendo o espaço a partir da lente do seu dispositivo, e há uma perspectiva negativa dessa relação, uma vez que "a cidade passa a ser reduzida a textos informacionais já que virtualmente tudo pode ser elemento de "etiquetagem eletrônica" e as etiquetas são as mesmas para qualquer usuário do sistema" (LEMOS, 2013, p. 9).

Realmente, não é como se o jogador tivesse tanta liberdade, haja vista que está sendo pautado pelo aplicativo, no entanto há sim, no caso de Pokémon GO uma relação com a cidade, de olhar ao redor, mesmo que seja para procurar elementos fornecidos pelo aplicativo e uma possibilidade de criar uma experiência pessoal.

Pensando sobre essa restrição, todos os aplicativos e plataformas seriam, portanto limitantes, uma vez que são pré-determinados pelo design e pelos objetivos das empresas que os fornecem, acabando completamente com o livre arbítrio do usuário, tal como foi criticado por Lanier e Morozov (2018), este último que conceituou que estamos vivendo um capitalismo tecnológico, no qual, ao ser examinado:

\footnotetext{
Não é difícil chegar a uma conclusão similar: no fundo, estamos diante de nosso próprio aquário digital, repleto de peixes mortos, que milagrosamente continuam a nadar. E fazem isso apesar dos crescentes indícios de que os sonhos utópicos, que estão por trás da concepção da internet como uma rede intrinsecamente democratizante, solapadora do poder e cosmopolita, há muito perderam seu apelo universal. A aldeia global jamais se materializou - em vez disso, acabamos em um domínio feudal, nitidamente partilhado entre as empresas de tecnologia e os serviços de inteligência. (MOROZOV, 2018, p. 15)
}

Afirma que atualmente não existe quase nenhuma restrição social, econômica ou política que o vale do silício não tenha se empenhado em romper, trabalhando na estratégia de fornecer ferramentas para enfrentar o sistema, produzidas por eles próprios, ao qual assegura que o seu maior êxito é na forma como "tornou-se a narrativa preponderante do próprio capitalismo contemporâneo" (MOROZOV, 2018, p. 20).

Em uma proposição contraditória ao conceito de onlife, acredita que a internet é tratada como uma entidade separada do funcionamento real da geopolítica e do atual capitalismo financeirizado e que desta forma: "enquanto não conseguirmos pensar fora da "internet", jamais conseguiremos fazer um balanço justo e preciso das tecnologias digitais à disposição" (MOROZOV, 2018, p. 22). 
Assim, o que de fato significa pensar "fora da internet"? Para ele, significa:

Ir além dos contos de fadas inventados pelo complexo industrialdivulgador do Vale do Silício. Significa prestar atenção às minúcias econômicas e geopolíticas do funcionamento de tantas empresas de alta tecnologia que atualmente nos escapam. (MOROZOV, 2018, p. 23)

Outro aspecto bastante criticado em sua pesquisa é a do conceito, que vem se popularizando, de cidade inteligente. Novamente, propõe uma leitura mais aguda e sistemática de algo que se vende como progressista, mas que seria uma forma de entregar a infraestrutura urbana para um grupo seleto de empresas de tecnologias, não adeptas da transparência, que realizará a administração à sua maneira e que tornará muito difícil a devolução à esfera do setor público.

Nesse sentido, é possível fazer uma crítica sobre a quantidade gigantesca de dados que o Pokémon GO produz diariamente sendo as informações mais variadas de localização, dos usuários, das cidades. Há sim um aspecto obscuro que não sabemos ao aceitar os termos de condição de uso de como são utilizados e até mesmo se estão protegidos esses dados. Acaba sendo uma condição estabelecida dentro do modelo capitalista contemporâneo do Big Data, em que se aceita uma série de termos em troca de serviços ditos como gratuitos, é uma troca realizada sem nenhuma transparência. É claro que a ética dos dados é um questionamento que poderia ser outra dissertação completa.

\subsection{1) Comentário sobre o jogo Minecraft Earth}

O jogo Minecraft é voltado para a criatividade e a proposta envolve a construção de blocos, permitindo a criação de diversos universos e:

Nos 10 anos desde que a primeira edição em Java foi publicada, ele vendeu 176 milhões de cópias. Mais de 90 milhões de pessoas jogam todos os meses, e esse número aumenta todos os anos, impulsionado mais recentemente por 200 milhões de usuários chineses. Entre PCs, consoles de jogos, dispositivos móveis e dispositivos de realidade virtual, você pode comprá-lo para 20 plataformas diferentes. (RUBIN, 2019 - tradução nossa) 
É um videogame bastante expressivo em números e no ano de 2019 a Microsoft - empresa que adquiriu jogo por mais de dois bilhões de dólares - anunciou o aplicativo em realidade aumentada: o Minecraft Earth, lançado em vários países está em fase de testes, o que chamam de early access.

O objetivo é que os jogadores/usuários possam colocar blocos em todos os espaços possíveis:

Os usuários de iOS e Android poderão criar uma "compilação", como os ambientes baseados em blocos são conhecidos, onde quiserem - em uma mesa, no sofá, no chão - e até convidar seus amigos para ajudar. Quando terminam, podem fazer com que a construção cresça em tamanho real e passear dentro dela. Em todo o mundo, em parques e em outros pontos de referência, os jogadores podem participar de pequenas aventuras sozinhos ou com qualquer outra pessoa na área, depois usar as ruínas para melhorar seu personagem e tornar sua construção ainda mais impressionante. É um empreendimento maciço que literalmente cobre todo o mundo no Minecraft - e é o maior passo já dado em direção ao mundo duplo da realidade aumentada compartilhada. (RUBIN, 2019 - tradução nossa)

É possível a criação de um universo compartilhado com outros jogadores, mas esses precisam ser autorizados a acessarem as construções e estarem na mesma localização no mundo real. São as experiências multiplayer, alguns voltados para combate e outros para exploração dos ambientes e "isso desbloqueia uma classe de experiências que nunca foram vistas em um jogo R.A. em dispositivos móveis: ações coordenadas que só podem acontecer se várias pessoas reais fizerem as coisas na ordem certa, no lugar exato" (RUBIN, 2019, n.p. - tradução nossa). Na figura abaixo se pode tem uma noção de como seria a mescla entre real e virtual.

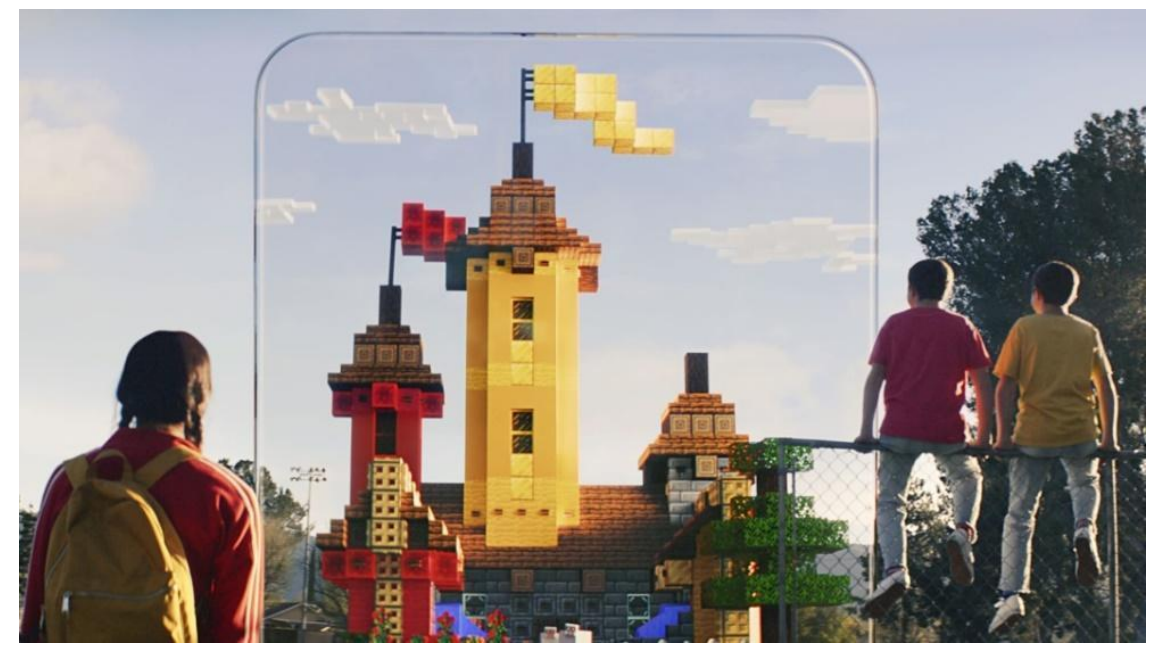

Figura 39: exemplo do Minecraft em R.A. 
Outra possibilidade que o jogo fornece é escalar o tamanho de algo a ser exibido, podendo ser do tamanho em dimensões humanas ou implantado em escalas monumentais.

Sobre uma comparação com o Pokémon GO:

A comparação óbvia aqui é o Pokémon GO da Niantic, bem como o próximo jogo Harry Potter: Wizards Unite. Ambos transformam o mundo real em um mapa do tesouro para você explorar e são capazes de trazer criaturas virtuais para o ambiente não virtual. No entanto, a funcionalidade RA em ambos é opcional. Se você desativá-lo, você tem basicamente dois jogos baseados em localização. O Minecraft Earth faz da RA a sua própria essência, e não apenas a RA compartilhada. Em outras palavras, pode ser a primeira experiência em larga escala em massa com um pé plantado diretamente no Mirrorworld. (RUBIN, 2019, n.p. - tradução nossa)

Para os criadores do jogo se trata de que todo aprendizado no Minecraft seja na vida real, ou seja, não é possível desativar a função em RA, de forma que não fiquem apenas na área de trabalho, como era o modelo anterior do jogo, almejam que as pessoas estejam juntas, como nos indica Rubin:

Você achou estranho o fenômeno Pokémon GO de grupos de pessoas apontando o telefone na mesma direção? Espere até ver a versão do Minecraft Earth: metade deles está girando em círculo, três estão agachados e fazem movimentos de escavação em direção ao chão, e alguns outros estão todos pulando. Melhor ainda: todos estão falando sobre isso. "Você pode coordenar perfeitamente como explorar uma área ou encontrar tesouros escondidos se estiver com estranhos, sem falar", diz Persson, "mas a interação social em torno do objetivo comum é uma parte essencial do que faz do Minecraft Earth um tipo diferente de multiplayer". (RUBIN, 2019, n.p. - tradução nossa) 
No frame abaixo, retirado de um vídeo publicitário no YouTube, é possível perceber como seria a relação virtual/real que o jogo proporciona.

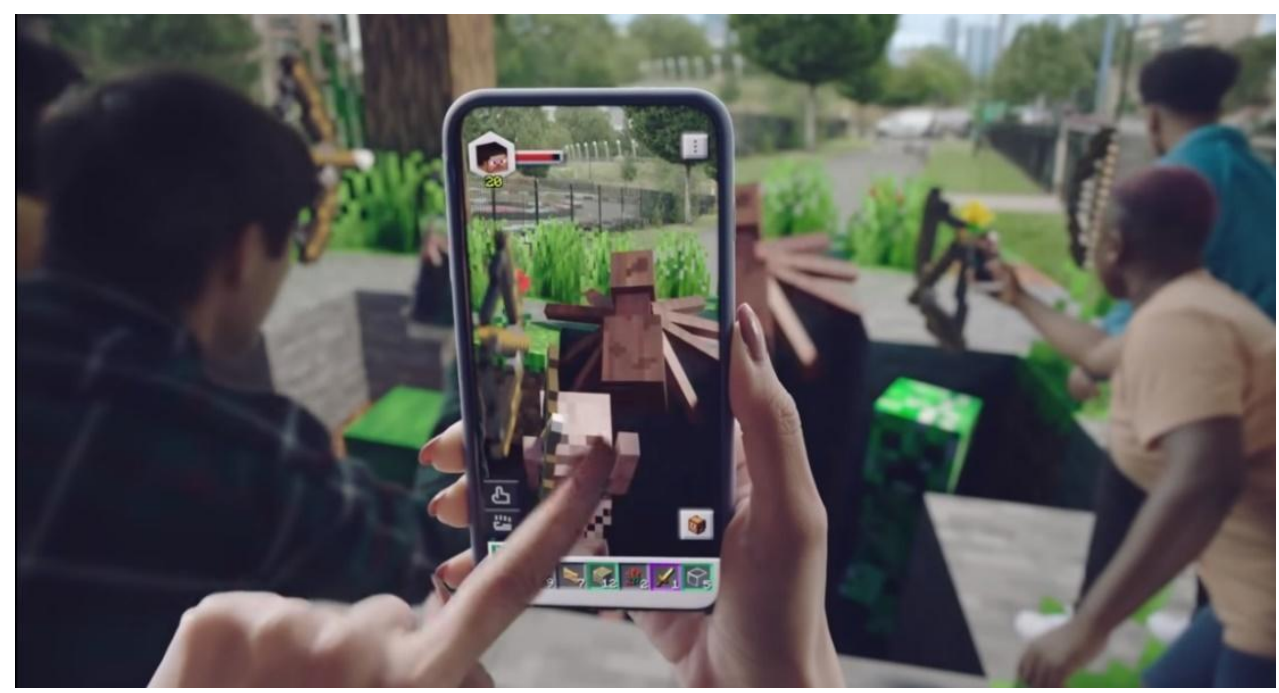

Figura 40: exemplo do Minecraft em R.A. modo combate 


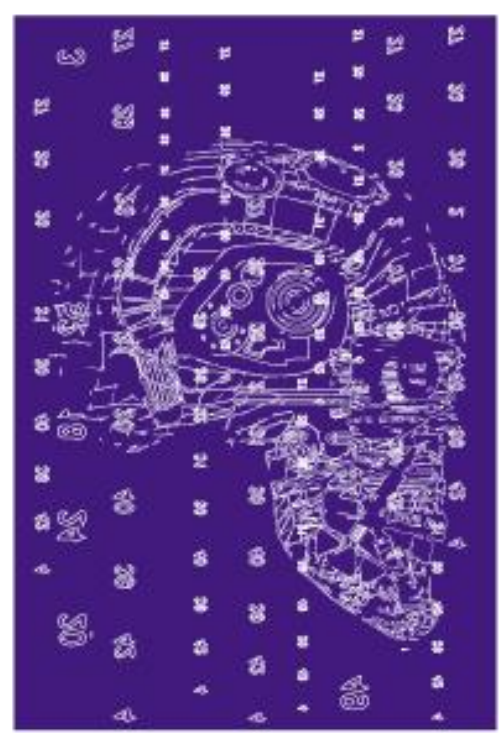

Capítulo IV - perspectivas sobre o que está por vir: Os futuros possíveis no big data 


\section{CAPÍTULO IV - PERSPECTIVAS SOBRE O QUE ESTÁ POR VIR: OS FUTUROS POSSÍVEIS NO BIG DATA}

O trabalho do pesquisador é a entrada no mundo da ciência e da tecnologia pela porta de trás, a da ciência em construção - tal como disse Latour -, sempre pelo questionamento e pela dança com a incerteza. Ao falarmos do homo digitalis, da quarta revolução, das redes sociais e da quantidade monumental de informações e atualizações tecnológicas aceleradas, o pesquisador que olha para a contemporaneidade realmente está num fluxo constante de dúvidas.

Esse quarto capítulo é uma tentativa de mapear caminhos possíveis e tendências do que virá, considerando todo esse contexto ao qual estamos inseridos. Existe, claro, uma parcela não tão pequena que entende a insegurança diante de tanta efervescência, de entender que está se analisando o furacão estando dentro do próprio.

A tendência é uma inclinação em direção a um sentido, uma propensão a essa orientação, de forma que pode muito bem se concretizar como pode ser considerado algo absolutamente irreal. A proposta desse capítulo é tentar realizar de alguma maneira o mapeamento de possíveis tendências para o futuro da comunicação e dos usos da realidade aumentada.

Nesse sentido, são previsões plausíveis de nunca serem realizadas, que projetam a "formação subsequente de um mundo melhor (virtual). A continuação de tradições inventadas ajuda a estender o passado (parcialmente) inventado para um futuro. O que quero enfatizar aqui é o grau de maleabilidade desses formulários" (HARTMANN, 2004, p.18 - tradução nossa).

Pensando sobre essa maleabilidade, há de se considerar o conceito de obsolescência programada quando se realiza um mapeamento de tendências. Pois se trata de uma estratégia mercadológica que incentiva o consumo repetitivo reduzindo o tempo de vida útil de um produto, de forma que os consumidores passem a consumir mais gerando uma excessiva desatualização das tecnologias. Há sempre um novo modelo com uma nova aparência ou não há mais nenhuma peça disponível para o conserto do aparelho que o sujeito já possui ou como quando os sistemas operacionais 
ou a própria tecnologia se torna lenta o suficiente para ser impossibilitada de ser utilizada, se tornando obsoleta e perdendo sua significância.

Esse limite tênue entre o que é um produto de alta tecnologia e o que é lixo é criticado por Crary em como esse intervalo é muito curto e obriga o consumidor a ter atitudes contraditórias, "tanto a necessidade e/ou desejo de um produto, como a identificação afirmativa com seu inexorável processo de aniquilamento e substituição" (CRARY, 2016, p. 53).

Destacamos aqui que isso é uma possibilidade, que algumas das tecnologias levantadas podem rapidamente ser substituídas ou serem atualizadas, pois essa é a lógica neoliberal, especialmente no que tange o consumo de tecnologias.

Não há limite para essa projeção, uma vez que a lógica que nos atinge não entende as limitações das matérias primas e a publicidade sempre encontra novos modelos para se reinventar para incentivar o consumo, a quebra dessa lógica é pela conscientização e consumo minimamente sustentável que não parece ser um panorama tão próximo.

Dito isso, entramos no que Floridi (2014) se pergunta e busca identificar filosoficamente como as forças tecnologias estão afetando nossas vidas:

\footnotetext{
Como nossas TIC digitais (tecnologias da informação e comunicação) estão afetando nosso self, como se relacionam e como moldamos e interagimos com o nosso mundo. Nanotecnologia, Internet das Coisas, Web 2.0, web semântica, computação em nuvem, jogos com captura de movimento, aplicativos para smartphones, tablets e telas sensíveis ao toque, GPS, realidade aumentada, companheiros artificiais, drones não tripulados, carros sem motorista, dispositivos de computação vestíveis, impressoras 3D, roubo de identidade, cursos online, mídias sociais, guerra cibernética...o tecnófilo e tecnófobo fazem a mesma pergunta: o que vem a seguir? (FLORIDI, 2014, p. vi - tradução nossa)
}

Questionando sobre esse futuro, sobre o que vem a seguir, Berardi (2019), pesquisador italiano da estética e da mídia, pergunta sobre o que se acreditou ser o futuro e o que vai ser depois desse futuro. Quando em 2009 o manifesto futurista completou cem anos, Berardi fez uma revisão da cultura do século XX marcado pela crença no futuro com uma visão muito eufórica em que "o horizonte parecia brilhante, 
mesmo que o caminho até o futuro fosse pavimentado com sofrimento, miséria, dificuldades e luto inimagináveis" (BERARDI, 2019, p. 7).

Existe o argumento de que, de fato, a vida humana melhorou em muitos sentidos, porém algo se quebrou na esfera psicossocial: "o sentimento que prevalece é a melancolia: a antiga metáfora do iluminismo foi subitamente virada do avesso. A expectativa moderna de expansão das luzes foi substituída por outra, um tanto oposta" (BERARDI, 2019, p. 7), o sentimento de se estar sozinho coletivamente, como Turkle, afirma foi intensificado.

Berardi propõe em sua análise uma revisão a respeito da máquina, que era central no imaginário da vanguarda futurista e que tomou uma centralidade ainda maior do que há cem anos. Podemos, portanto, relacionar com a nomenclatura dos gadgets de Lanier e dispositivos de Agamben:

\begin{abstract}
A máquina está no centro do mundo imaginário futurista. Trata-se da máquina externa, a máquina pesada, ferruginosa e volumosa, que não deve ser confundida com a máquina internalizada e reprogramável da época bioinformática, a nossa época, a nova época que se inicia após o final do século que acreditou no futuro e se mostra em toda a sua potência imaginaria e pratica com a concretização do projeto genoma e com a progressiva transformação do sistema produtivo global pela rede que conectou seres humanos e automatismos mecânicos. Vivemos hoje, no século XXI, rodeados e penetrados por máquinas internas, máquinas infobioécnicas, cujo funcionamento e cujos efeitos sobre a evolução cultural da espécie humana não somos ainda capazes de avaliar plenamente. (BERARDI, 201, p. 159)
\end{abstract}

O que se mostra essencial em seu pensamento é a completa alteração da máquina, no sentido de que antes a máquina era externa que agia fora do corpo e da mente e hoje:

Temos que falar da máquina interiorizada, máquina biopolítica: a máquina psicofarmacológica, a máquina que age no interior do corpo graças a potência do tipo químico, biotécnico. E, ainda mais, a máquina semiótica, a rede como concatenação que torna possível uma deslocalização dos processos produtivos. Para realizar deslocamentos progressivos e de formas diferenciadas, a máquina deixou de ser a máquina adorada pelo futurismo para se tornar uma máquina essencialmente internalizada: a máquina de controle. (BERARDI, 2019, p. 17)

Sendo assim, a disseminação da máquina toma outras proporções se tornando um dispositivo miniaturizado, se faz signo, relação e linguagem que modela quem a 
utiliza, abole o espaço "porque o espaço é suprimido em uma temporalidade instantânea e deslocalizada" (BERARDI, 2019, p. 17).

Sobre a aceleração do 24/7 Berardi entende que com o ciberespaço é ilimitado e em continua expansão, porém, o cibertempo não, seus limites são orgânicos, são da mente humana, emocionais e culturais.

Uma noção que foi essencial no século XX foi a de utopia, no que se projetou do futuro e as experiências que alegaram ser baseadas em utopias foram geralmente marcadas pelo totalitarismo e violência. Pondera assim que a utopia demorou muito a morrer nesse século e sua última manifestação é a utopia virtual:

A utopia virtual nasce no ponto de divergência e depois de convergência entre a rede - o espaço comum do compartilhamento social e cognitivo - e o sistema integrado do capital global. O salto tecnológico do capitalismo foi possível por dois fatores: a desregulamentação da economia e a construção da internet. Mas os dois processos não são assimiláveis, aproximam-se, distanciam-se, entram em conflito, integram-se, parasitam-se mutuamente. (BERARDI, 2019, p. 103)

Posto isso, há uma contraposição entre cibertempo e ciberespaço, de forma que o tempo foi colonizado:

\begin{abstract}
Ciberespaço é a esfera de interação de várias fontes humanas e mecânicas de enunciação, a esfera da conexão entre mentes e máquinas; essa esfera está em expansão virtualmente ilimitada, pode crescer indefinidamente, porque é o ponto de intersecção do corpo orgânico com o corpo inorgânico da máquina eletrônica. Mas o mesmo não se pode dizer do cibertempo. O cibertempo é o lado orgânico do processo, o tempo necessário para que o cérebro humano possa elaborar a massa de dados informativos e de estímulos emocionais provenientes do ciberespaço. (BERARDI, 2019, p. 109)
\end{abstract}

O que é paradoxal são as diferenças da expansão da velocidade de tal forma que os sujeitos são oprimidos pela saturação da atenção. É uma experiência muito densa da qual o cérebro humano ainda não está completamente adaptado.

Desaprova a perspectiva sobre a cibercultura, que considera cor de rosa, exemplificando com Pierre Levy. Afirma que há uma face da cibercultura bastante distópica e obscura tal como a teoria do enxame de Kelly (1994), na qual a rede seria uma espécie de superorganismo bioinformático em que os elementos orgânicos, biológicos, cognitivos e eletrônicos estariam todos em um continuum indistinguível, de forma que "a lógica do bios é importada para as máquinas, a lógica da tekné é 
importada para a vida humana e para os mesmos comportamentos inteligentes da vida social” (BERARDI, 2019, p. 129).

Berardi traz uma visão catastrófica do presente e do futuro, em que esse se transforma em devastação, miséria, violência, hipersexualização, depressão, isolamento e suicídio porque "a utopia virtual devorou o futuro. Retirou-se da esfera da imaginação e da vontade humana. A utopia virtual culmina na distopia de um totalitarismo sem vontade" (BERARDI, 2019, p. 131).

Apesar desse cenário sombrio, propõe então uma possibilidade de pensar não um só futuro, mas muitos: "pensemos então em termos de futurabilidade, a intrínseca pluralidade de futuros possíveis inscritos no presente" (BERARDI, 2019, p. 178).

A futurabilidade seria: "a multidimensionalidade do futuro, a pluralidade dos futuros inscritos no presente e, também, a composição mutável da intenção coletiva. Futurabilidade é a dimensão na qual uma possibilidade se torna tendência" (BERARDI, 2019, p. 182).

Queremos ter uma leitura conjuntural que abarca essa multipluralidade do futuro, considerando que "claramente, encontramo-nos hoje novamente em uma crise, em uma transição crítica, pela qual uma outra revolução, a saber, a revolução digital, parece ser responsável" (HAN, 2018, p. 26). Torna-se inevitável abordar sobre o poder das grandes empresas do Vale do Sicílio, que propõem os moldes para a sociedade do homo digitalis, na qual há uma egotização crescente e atomização da sociedade encolhendo os espaços para o agir em conjunto e impedindo, assim, "a formação de um contrapoder que pudesse efetivamente colocar em questão a ordem capitalista" (HAN, 2018, p. 31).

É como se todos os sujeitos hoje sofressem de SFI (síndrome da fadiga de informação), de um cansaço da informação e "a razão disso é que todos somos confrontados com quantidades rapidamente crescentes de informação" (HAN, 2018, p. $105)$.

Nam June Paik é um artista coreano que desde a década de 1960 utiliza a discussão da tecnologia em sua poética. Na instalação Sistine Chapel, realizada novamente em 2019 para uma exposição individual do artista chamada The Future is Now, tem-se uma leitura desse futuro sobrecarregado de informações visuais, uma colagem audiovisual de imagens e apropriações, quase como um trabalho sobre a 
remixagem. Na vista da instalação abaixo é possível apreender a saturação visual e em como foi realizada de forma a convidar o espectador a entrar nessa dimensão tridimensional.

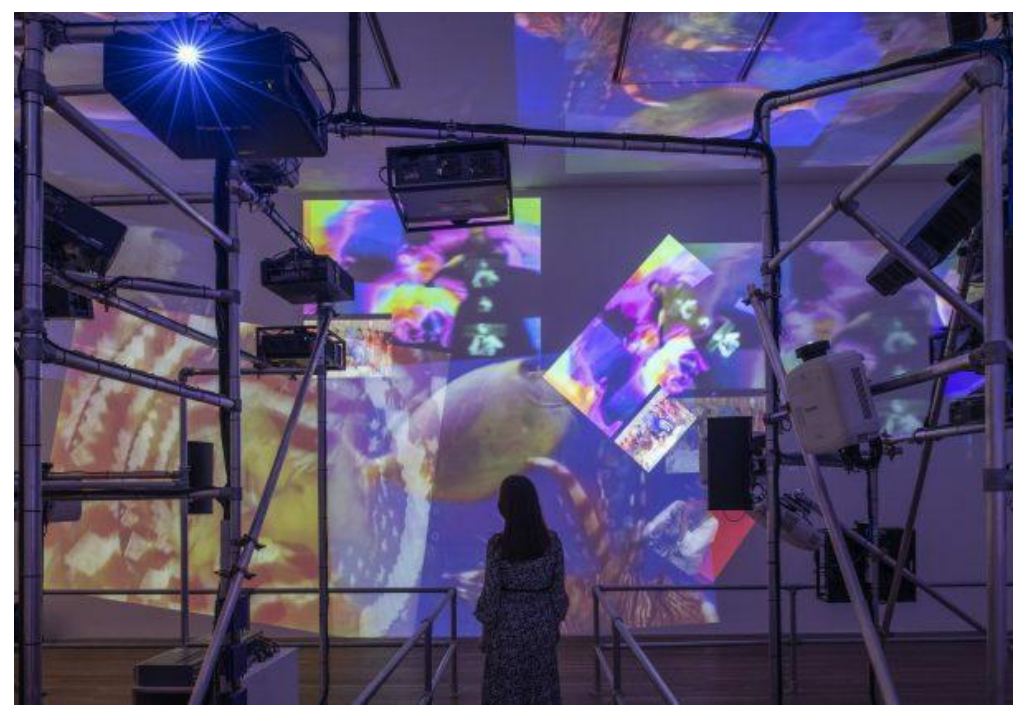

Figura 41: Vista da instalação Sistine Chapel em 2019 na Tate Modern

Essa sobrecarga da informação total permite também outro aspecto perverso que é a vigilância total, que Han chama de panóptico digital. Nele, não é possível estabelecer nenhum tipo de relação de confiança, haja vista que: "todo clique que eu faço é salvo. Todo passo que eu faço é rastreável. Deixamos rastros digitais em todo lugar. Nossa vida digital se forma de modo exato na rede. (HAN, 2018, p. 122). Assim, no lugar do anterior Big Brother tem-se agora o Big Data.

Data que vem da "etimologia do termo 'dados' e tem origem no latim datum ('aquilo que se dá'), que é o particípio do verbo dare (dar). Tais significados podem ser contrastados com a ideia de 'fato', facere no latim, que remete àquilo que já foi feito, que está pronto ou existe" (VENTURELLI; MELO, 2019, p. 204).

Big Data foi um termo cunhado em meados dos anos 1990 no Vale do Silício para "se referir à manipulação e análise de massivos conjuntos de dados. Apesar de não existir consenso quanto à definição precisa do termo Big Data, é relativamente consensual a compreensão do fenômeno no que ficou conhecido como $3 \mathrm{Vs}$ : volume, velocidade e variedade" (VENTURELLI; MELO, 2019, p. 206). 
Sobre o Big Data Morozov (2018) traz uma perspectiva um tanto repulsiva relativamente à estrutura da sociedade contemporânea sendo ele um dos pensadores atuais mais críticos a respeito da visão de mundo projetada pelo Vale do Silício que está permeada de forma disseminada e ao qual afirma que "mantém um controle firme das engrenagens do debate público" (MOROZOV, 2018. p. 29).

$\mathrm{O}$ autor elabora uma série de textos de forma a dissecar os temas de inteligência artificial, Big Data, economia compartilhada e inovação complexificando para além dos seus efeitos positivos e potencialmente salvadores.

$\mathrm{O}$ autor afirma que quando há um desvio do enfoque regulador do controle corporativo para o contínuo direcionamento eletrônico dos indivíduos a regulação algorítmica mantém a ordem e utopia tecnocrática da política apolítica (MOROZOV, 2018, p. 92). É o que chama de monitoramento e Han chama de vigilância permanente, ambos com o efeito panóptico e o que aparenta ser um perigo dentro dessa regulação é que independente dos benefícios imediatos "nos dará um regime político no qual todas as decisões serão tomadas pelas empresas de tecnologia e pelos burocratas estatais" (MOROZOV, 2018, p. 101).

Isso acarreta uma intensificação do controle e essa relação estabelecida é assimétrica, haja vista que o maior foco da visibilidade e do Big Data é o cidadão comum, que é vigiado e monitorado por todo tipo de dispositivo inteligente ao qual se rodeia.

Na mesma medida em que este indivíduo está sob o regime de hipervisibilidade, os outros agentes sociais e políticos estão sob uma crescente hiperinvisibilidade e continuam a agir com um instrumental obscuro e quase impenetrável, uma vez que:

As ferramentas dos dividendos da vigilância funcionam apenas num nível: o do cidadão como indivíduo. Elas o tornam totalmente transparente e manipulável, criando um simulacro de "solução de problemas", ao mesmo tempo que permitem que governos e empresas persigam com liberdade os próprios projetos. Parafraseando Foucault, todos nos tornamos eminentemente rastreáveis e eminentemente suscetíveis a "fazer a melhor escolha" (MOROZOV, 2018, p. 114).

O curioso é que esse habitante do panóptico, o cidadão no caso não é prisioneiro, eles acreditam na ilusão da liberdade vendida a eles, abastecendo o panóptico digital "com informações que eles emitem e expõem voluntariamente" (HAN, 2018, p. 123), que seriam os prosumers. 
Essa intensificação do controle já havia sido preconizada por McLuhan quando afirmou que o poder e o controle na maioria dos casos são pagos pela perda da liberdade e da flexibilidade (MCLUHAN, 1995, p. 303 - tradução nossa).

Portanto, com efeito, a contemporaneidade deveria ser uma sociedade da convergência. Contudo, o que se tem atualmente é uma única rede na qual as tecnologias convergiram para a opção menos segura e mais favorável à interceptação das mensagens (MOROZOV, 2018 p. 123) e seu uso de forma opaca.

Na medida em que os objetos vêm deixando cada vez mais de serem analógicos e passam a ser inteligentes, o modelo utilizado pela empresa Google vai ser difundido. Modelo esse que funciona da seguinte maneira: a empresa realiza uma coleta de dados via e-mail, o algoritmo vasculha as informações para produzir um anúncio personalizado e baseado em análises e classificações automatizadas em tempo real. Esse método é bastante custoso apesar do sistema ser gratuito e é isso que o torna mais atrativo aos usuários, essa ilusão da liberdade dentro do panóptico.

Esse modelo pode ser expandido, ou seja, todo objeto inteligente é capaz de gerar um rastro de dados e esses dados não necessariamente precisam vir apenas do celular, mas sim de qualquer um dos meios que os produzem, seja a escova de dente ou a lixeira inteligente. "Em outras palavras, você recebe de graça uma escova de dente inteligente, mas, em troca, permite que ela colete dados sobre como é usada. São esses dados que financiarão o custo da escova" (MOROZOV, 2018, p. 129).

Os cidadãos usuários optam por utilizar tais transações de forma voluntária, assim como já utilizam o e-mail gratuito ou os e-books, que são mais baratos e o fazem de boa vontade. O caminho então seria de uma catástrofe informacional e sob uma perspectiva de que utilizar esses objetos inteligentes não estão afetando ninguém além do usuário, ou seja, uma completa falta de dimensão e consciência.

A preocupação é da mercantilização do sujeito, assim como qualquer outra mercadoria e no quanto essas ações que aparentam ser mínimas e individuais, possuem consequências políticas e morais no consumismo informacional. Para Morozov o compartilhamento de informações talvez seja o polo de um mercado em crescimento e vibrante de novidades, porém falta-lhe o enquadramento ético. Afirma que: "essas 'questões digitais' são de fundamental importância para o futuro da privacidade, da autonomia, da liberdade e da própria democracia” (MOROZOV, 2018, p. 135). 
Essa construção teórica e conceitual caminha para o delineamento de um panorama baseado no chamado Big Tech, um momento absolutamente inédito na história da humanidade e que demanda reflexões e diagnósticos de um processo ainda em desenvolvimento. A ascensão do Big Tech seria das grandes empresas associadas a plataformas de uso intensivo de dados, majoritariamente norte-americanas e com um recente crescimento na China:

\begin{abstract}
A ascensão da Big Tech não é vista como sintoma da crise econômica mundial, do enfraquecimento das leis antimonopolistas ou da privatização do bem-estar e outras funções do Estado. Em vez disso, ela aparece principalmente como uma solução para todos esses problemas - e, na mais ambiciosa dessas visões, como garantia de que um novo compromisso político e econômico - uma espécie de New Deal - seja firmado. (MOROZOV, 2018, p. 145)
\end{abstract}

Outro fator levantado foi de que na década de 1990, houve uma suposição de que os antigos conflitos causados pelas classes ou o acesso desigual à propriedade seriam passado e com as redes um mundo sem classes estava sendo projetado, graças à tecnologia digital, o utopismo tecnológico, do que seria a "predominância dessa ideologia tecnoutópica que permite ao projeto como um todo - aquele convencido de que vivemos numa sociedade sem classes e de que os grandes conflitos por recursos econômicos são coisa do passado - prosseguir sem contestação" (MOROZOV, 2018, p. 173).

Realiza também uma avaliação a respeito da aldeia global, principalmente do seu caráter utópico, e que, apesar de não apresentarem resultados concretos, havia um espírito positivo de internacionalismo e em como olhando a partir de uma perspectiva crítica e temporal, é possível perceber que a percepção da década de 1970 falhou em explicar:

\footnotetext{
Tanto o poder corporativo como os interesses geopolíticos e estratégicos de governos pouco interessados em abdicar das atividades de vigilância. Nenhuma aldeia global pode vir a existir enquanto não houver infraestruturas sustentáveis para a comunicação e troca de informações, o que só é possível com recursos financeiros. (MOROZOV, 2018, p. 180)
}

Assim, mostra-se com essencial ter a capacidade de distinguir entre o tecnoutopianismo realista e o ingênuo, ao qual o último foi bastante ineficaz, e primordialmente: "recuperar o papel da tecnologia como uma força emancipatória, que não se limita ao papel neoliberal que lhe é atribuído pelo Vale do Silício: talvez essa 
seja a maior contribuição para a sociedade civil pode dar ao atual debate digital" (MOROZOV, 2018, p. 182).

Apesar de indicar-se como um crítico ferrenho e apocalíptico, ainda existe um fundo esperançoso que retorna ao potencial da rede como uma possibilidade democrática, como uma possibilidade de empoderamento dos cidadãos, claro, somente a partir do profundo diagnóstico e revisão dos fundamentos do capitalismo digital e que talvez assim a parte encantadora da aldeia global se concretize de alguma forma, na qual seria necessário:

(...) fazer com que os anúncios virtuais - e a ânsia destrutiva de clicar e compartilhar que os acompanha - tenham menos influência no modo como vivemos, trabalhamos e nos comunicamos. Ao mesmo tempo, precisamos delegar mais poder de decisão aos cidadãos - e menos a especialistas facilmente corrompidos e corporais venais. Isso significa construir um mundo em que o Facebook e o Google não exerçam tanta influência, nem monopolizem a solução de problemas. Uma tarefa formidável e digna de democracias maduras. Lamentavelmente, as democracias existentes, imobilizadas em suas múltiplas negações, preferem culpar todos, em vez de si mesmas, enquanto descarregam mais e mais problemas no Vale do Silício (MOROZOV, 2018, p. 187).

Percebe-se o quanto há sim preocupação e uma desesperança em relação aos futuros possíveis, especialmente ao que seria um presente mais justo, igualitário e com uma liberdade propriamente dita. São reflexões acerca dos valores contidos na rede e que acaba por demonstrar o quanto muitos desses interesses são pautados pelo mercadológico gerando uma série de desigualdades sociais e políticas.

\section{1) Os usos da realidade aumentada em um futuro próximo - os vestíveis (wearables)}

Realizada essa breve estudo sobre os futuros possíveis - talvez mais uma compilação de percepções calamitosas acerca desses futuros -, podemos entrar em um mapeamento dos usos e das tendências emergentes em realidade aumentada, ou o que esperamos que se tornem na era da informação total, do que Berardi pontuou como máquina interiorizada e máquina biopolítica e chegando ao que é uma das maiores tendências de um futuro próximo: os vestíveis (wearables), um acoplamento humano/máquina, que seriam o que Floridi chamou de revolução (ou evolução) da mobilidade. 
Bostrom (2018) entende o acoplamento de tecnologias como um caminho previsível, de modo que o "desenvolvimento de uma tecnologia tenha uma forte tendência de levar ao desenvolvimento de outra, tanto como um precursor necessário ou como uma inevitável e irresistível etapa subsequente" (BOSTROM, 2018, p. 477).

Aqui, retomamos a discussão de McLuhan sobre as próteses (prolongações, para Flusser) e como são extensões, sendo essas do corpo e das faculdades cognitivas:

\begin{abstract}
As próteses tecnológicas moldam a nossa percepção e possuem um papel decisivo nos modos como nós pensamos e formalizamos o conhecimento. Assim, talvez devêssemos nos perguntar sobre o tipo de regime perceptivo que vem sendo imposto pela crescente onipresença dos aparelhos digitais. (BASBAUM, 2005, p. 9)
\end{abstract}

A integração ao corpo de forma hiperconectada faz com que sejam relacionados os corpos com as experiências, os dispositivos e as percepções: “o McLuhanism implica a aceitação e a exploração da tese de que o meio é a mensagem, e que grande parte dessa mensagem pode ser descrita em termos do impacto de certa mídia sobre nosso viés de percepção" (BASBAUM, 2019, p. 88 - tradução nossa).

Nesse sentido, McLuhan previa que chegaríamos a uma fase final, mais extremada, de simulação tecnológica da consciência, da qual Kerckhove entende a integração tecnológica a um nível de interatividade biológica homem/máquina na R.V. Podemos levar para a R.A. também, já que a base disso seria que essa conectividade como uma nova experiência dos homens, gerando um novo ser capaz de combinar a conectividade com a subjetividade.

Pensando assim, tem-se a absorção do smartphone ao corpo, tal como é a proposta do Google Glass, este que "liga o olho humano diretamente à internet. Seus usuários, por assim dizer, veem a tudo. Eles introduzem a era da informação total" (HAN, 2018, p. 79). Torna-se um componente do corpo do sujeito que "completa a sociedade da informação ao fazer com que o ser coincida inteiramente com a informação" (HAN, 2018, p. 79).

Se pensarmos em relógios, ipods, câmeras fotográficas, smartphones, enfim, todas as tecnologias anteriores de alguma forma eram vestíveis também, no entanto, os vestíveis digitais (wearables) são acoplados ao corpo, permitindo maior mobilidade. 
Existe uma grande variedade de termos que se referem aos vestíveis, tais como computadores vestíveis, tecnologia fashion (fashionable technology) e vestíveis fashion (fashionable wearables).

Seymour (2008) define graus de integração da tecnologia ao corpo sendo eles:

- computador de mão (handheld): os dispositivos móveis junto ao corpo;

- vestível (wearables): relacionados à moda em que a roupa ou outro acessório é recipiente para a tecnologia, ou a tecnologia está fisicamente embutida em roupas ou tecidos e substratos técnicos e científicos são integrados ao tecido;

- implantado (implanted): ou seja, implantes como chips ou estéticos e tatuagens (SEYMOUR, 2008, p. 14 - tradução nossa).

Radfahrer (2019) utiliza o termo tatuáveis para uma tatuagem eletrônica que introduz um chip na pele, sendo uma intervenção não cirúrgica que pode ter diversos funcionamentos como um GPS na pele.

De forma que as tecnologias incorporadas influenciam a usabilidade, o conforto e a estética de um vestível capturam data e devem estar próximas da pele para serem eficazes, podendo ser tanto com estrutura rígida ou com suporte têxtil e de alguma forma esse corpo se altera por essas extensões.

Melhor dizendo, um dispositivo com internet das coisas (IoT) é um vestível, apesar de alterar uma lógica perceptiva ainda é possível ser retirado do corpo, o que é bastante diferente das lentes de contato, como será visto mais afundo.

Isso indicaria um aperfeiçoamento do corpo, mas para Le Breton seria o contrário seria um grande desprezo já que "o corpo é hoje frequentemente percebido como um arcaísmo, a relíquia indigna de uma condição humana que entra na era da póshumanidade" (LE BRETON, 2019, p. 89). Para o autor é por meio da distinção ambígua entre o homem e seu corpo, pela assimilação mecânica do biológico que o corpo perde valor moral e mais cresce o valor técnico e mercadológico, há um sonho do acoplamento do homem com o que ele chama de informática na forma de cyborg (LE BRETON, 2019, p. 91).

Questão essa que nos aproxima mais ainda do campo da ficção científica: 


\begin{abstract}
A ficção científica sempre esteve muito interessada nas consequências que as novas tecnologias poderiam ter sobre o corpo; do cinema à literatura, muitos foram os romancistas que entenderam que, no "futuro", o homem iria querer mudar sua condição corporal e que a noção de corpo se constitui como uma grande musa da imaginação futurista. (MALYSSE, 2000, p.273)
\end{abstract}

Essa demarcação não definida, quase transparente entre atores humanos e a tecnologia, os não humanos, vem sido chamada de computação ubíqua, termo cunhado na década de 1990 por Mark Weiser. Ressaltando que os limites não são nítidos, especialmente entre inteligência artificial e programas de computador e quando não há mais a necessidade de conectar ou ligar ou desligar o dispositivo, de forma que o sujeito não precisa mais estar ciente da estrutura computacional que está embutida nesses dispositivos.

Computação ubíqua quer dizer:

(...) que os computadores, cada vez mais imperceptíveis na sua natureza de computadores, estão em todos os lugares. Vem daí a palavra "pervasiva", significando que, por meio da introdução proliferante de chips, a computação passa através de todas as coisas, especialmente quando estas, senscientes, equipadas como sensores ou etiquetas de RFID, trocam informações com computadores. (SANTAELLA, 2011, p. 135)

Outra filosofia que defende a aplicação e acoplamento da tecnologia nos atores humanos é o transhumanismo, que entende que a tecnologia permite a superação dos limites impostos pela condição humana e que pode superar também todo o sofrimento. Assim, trata-se da utilização de forma onipresença e ininterrupta da tecnologia e nos guiar à condição pós-humana.

Na declaração Transhumanista ${ }^{31}$ os pesquisadores colocam que:

A humanidade deve ser profundamente afetada pela ciência e tecnologia no futuro. Prevemos a possibilidade de ampliar o potencial

\footnotetext{
${ }^{31}$ A Declaração Transhumanista foi originalmente criada em 1998 por um grupo internacional de autores: Doug Baily, Anders Sandberg, Gustavo Alves, Max More, Holger Wagner, Natasha Vita-More, Eugene Leitl, Bernie Staring, David Pearce, Bill Fantegrossi, den Otter, Ralf Fletcher, Tom Morrow, Alexander Chislenko, Lee Daniel Crocker, Darren Reynolds, Keith Elis, Thom Quinn, Mikhail Sverdlov, Arjen Kamphuis, Shane Spaulding e Nick Bostrom. Esta Declaração Transhumanista foi modificada ao longo dos anos por vários autores e organizações. Foi adotado pelo Conselho da Humanity + em março de 2009. Disponível em: https://humanityplus.org/philosophy/transhumanist-declaration/. Acessada em: 08/07/2020.
} 
humano superando o envelhecimento, deficiências cognitivas, sofrimento involuntário e nosso confinamento ao planeta Terra. (...)

Reconhecemos que a humanidade enfrenta sérios riscos, principalmente pelo uso indevido de novas tecnologias. Existem possíveis cenários realistas que levam à perda da maioria, ou mesmo de tudo, do que consideramos valioso. Alguns desses cenários são drásticos, outros são sutis. Embora todo progresso seja mudança, nem toda mudança é progresso. (...)

A redução dos riscos existenciais e o desenvolvimento de meios para a preservação da vida e da saúde, o alívio do sofrimento grave e o aprimoramento da perspicácia e da sabedoria humana devem ser perseguidos como prioridades urgentes e fortemente financiados.

A elaboração de políticas deve ser guiada por uma visão moral responsável e inclusiva, levando a sério as oportunidades e os riscos, respeitando a autonomia e os direitos individuais, mostrando solidariedade e preocupação com os interesses e a dignidade de todas as pessoas ao redor do mundo. Também devemos considerar nossas responsabilidades morais em relação às gerações que existirão no futuro.

Defendemos o bem-estar de toda a consciência, incluindo seres humanos, animais não humanos e quaisquer intelectos artificiais futuros, formas de vida modificadas ou outras inteligências às quais o avanço tecnológico e científico possa dar origem.

Somos a favor de permitir aos indivíduos ampla escolha pessoal sobre como eles possibilitam suas vidas. Isso inclui o uso de técnicas que podem ser desenvolvidas para auxiliar a memória, concentração e energia mental; terapias de extensão da vida; tecnologias de escolha reprodutiva; procedimentos criônicos; e muitas outras possíveis tecnologias de modificação e aprimoramento humano. (Transhumanist Declaration, 1998/2009, n.p - tradução nossa)

Assim, no trecho da declaração consegue-se perceber que essa perspectiva sobre o futuro abarca os atores humanos e não humanos de forma que tenha a preservação da vida e da saúde e o bem-estar de toda a consciência, seja qual for esta, além da abertura para uma possibilidade da prolongação talvez eterna da vida. É uma visão muito mais positiva das mediações e do futuro.

Os transhumanistas argumentam que é uma questão de grau de intervenção para tornar a vida mais longa e melhor, em que não há diferença categórica entre muitos procedimentos médicos modernos e a busca para vencer a morte (ITO, 2018, n.p. tradução nossa). Ou seja, a visão de futuro deles é um no qual se pode transcender as limitações da biologia humana.

Há aqui uma série de questionamentos éticos que retomam o início da revolução industrial, em que se estimava que o corpo fosse uma máquina. Sabe-se, no entanto, que não se comporta como uma, pois não foi inventado e, portanto, não pode ser programado. Essa talvez seja a maior crítica relativa à filosofia transhumanista.

Le Breton (2019) afirma que o corpo é moldado pelo contexto social e cultural em que o ator está inserido e em como o corpo reage na relação construída com o 
mundo, assim, a existência do humano é corporal e sua expressão é modulável - assim como a percepção - de forma que se pensarmos em um futuro de influência tecnológica ininterrupta, o corpo será irremediavelmente afetado de formas estruturais.

Além disso, a expectativa do corpo como máquina confia no funcionamento de dispositivos que podem muito bem ser falhos ou rapidamente se desatualizarem.

Um adendo bastante relevante sobre a teoria transhumanista é que nem toda tecnologia exige ser acoplada ou incorporada ao corpo em cirurgias, eles entendem que as extensões tais como os smartphones já estão nesse caminho de fusão com a tecnologia. Entendem que a delegação de funções e tarefas para tecnologias externas à mente humana já nos dá novas habilidades:

Está sempre perto do nosso corpo, é quase impossível viver ou trabalhar sem, e isso nos dá novas habilidades, como poder descobrir quase tudo com muita facilidade". É claro, acrescenta Gafsou, há uma troca inevitável. "O smartphone também roubou algo de nós - nossa memória, nossa capacidade de nos orientar no espaço nas cidades. (HARDY, 2019, n.p. - tradução nossa)

Outro eixo de crítica é a questão econômica, uma vez que é bem possível que,

a capacidade de transcender a mortalidade exacerba a desigualdade econômica. Alguns argumentam que apenas os ricos se tornarão imortais, enquanto outros afirmam que, como o smartphone, outras tecnologias transhumanistas estarão inicialmente disponíveis apenas para os ricos, mas rapidamente caem de preço. (HARDY, 2019, n.p - tradução nossa)

De qualquer forma, é uma discussão pautada na incorporação quase transparente da tecnologia no cotidiano, na sociedade, na vida e nos corpos dos sujeitos.

Pensando nesses acoplamentos, o smartphone tem sido um dos fatores de aumento da acessibilidade e de disseminação com a linguagem realidade aumentada, especialmente com as redes sociais, os jogos e aplicativos e, por conseguinte haveria uma expansão desses dispositivos. Assim, a partir dessa ampliação o que parece ser o caminho dos usos é a utilização de múltiplas mídias ao mesmo tempo, mais imersão e borramento entre os limites da visão e do que é vestível. O investimento nesse campo de linguagem tem projeção de estar nos bilhões, tal como percebido abaixo. 


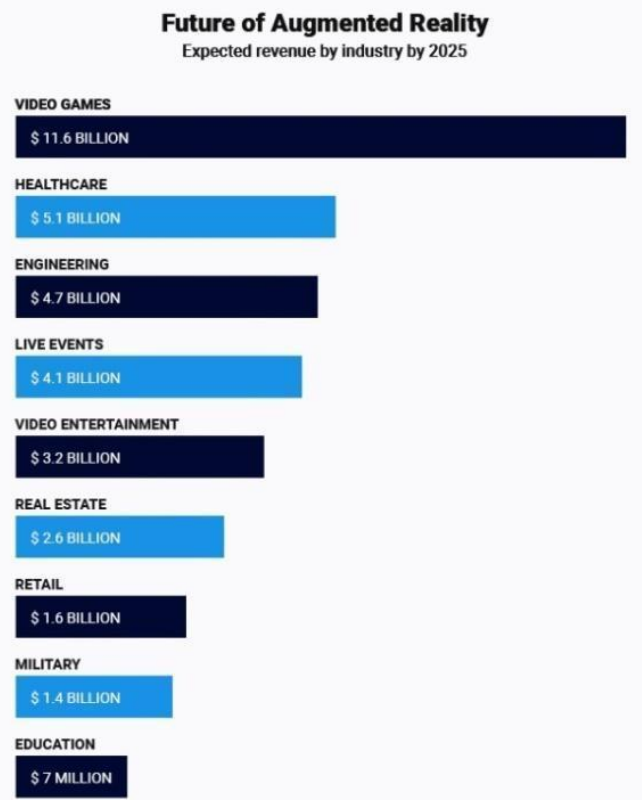

Figura 42: Futuro da realidade aumentada em 2025 pela Lumus Vision ${ }^{32}$

De acordo com Hartmann (2004) as tendências futuristas ou o que nomeia de futuro inventado tem bastante a ver com a natureza da tecnologia que convida a reivindicações futuras em que:

O futuro inventado é outra expressão da forma cultural da internet, isto serve para fornecer estabilidade onde não há necessariamente. $\mathrm{O}$ inventado potencialmente impulsiona o desenvolvimento, mas também romantiza e exagera a suposta necessidade social implícita na invenção. (HARTMANN, 2004, p.17 - tradução nossa)

O Google Glass tem gravação de vídeo e projeção na borda dos óculos e de acordo com a definição do Google "o glass é um computador portátil leve, com uma tela transparente para o trabalho com as mãos livres" 33 tal como é percebido no modelo dos óculos Enterprise Edition 2 abaixo.

\footnotetext{
32 Disponível em: <https://lumusvision.com/augmented-reality-trends-infographic/>. Acesso em $22 \mathrm{de}$ out. de 2019.

${ }^{33}$ Disponível em: https://www.google.com/glass/start/. Acesso em 17 de mar. de 2020.
} 


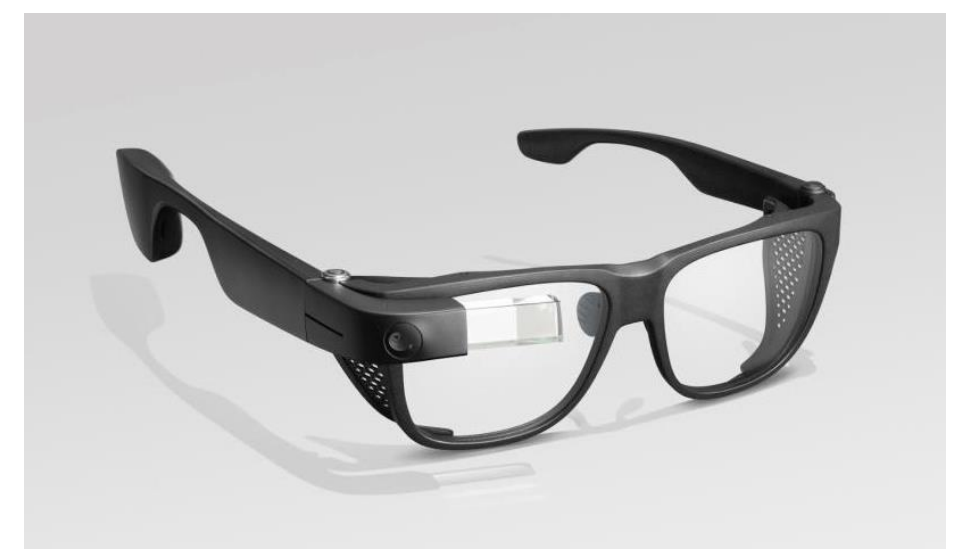

Figura 43: modelo do Glass Enterprise Edition 2

No mesmo sentido de produção, a Microsoft vem desenvolvendo o HoloLens ${ }^{34}$, que no lugar de um prisma tem dois prismas para visão e pode projetar imagens em 3D, seria, de acordo com a definição da Microsoft:

O HoloLens 2 oferece a experiência de realidade mista mais confortável e envolvente disponível, com soluções líderes do setor que agregam valor em minutos - tudo aprimorado pela confiabilidade, segurança e escalabilidade dos serviços de nuvem e IA da Microsoft. (2020 - tradução nossa)

É um dispositivo mais robusto que o Google Glass e potencialmente mais profundo na mescla real/virtual por possuir mais de um prisma. Abaixo um exemplo de sua utilização.

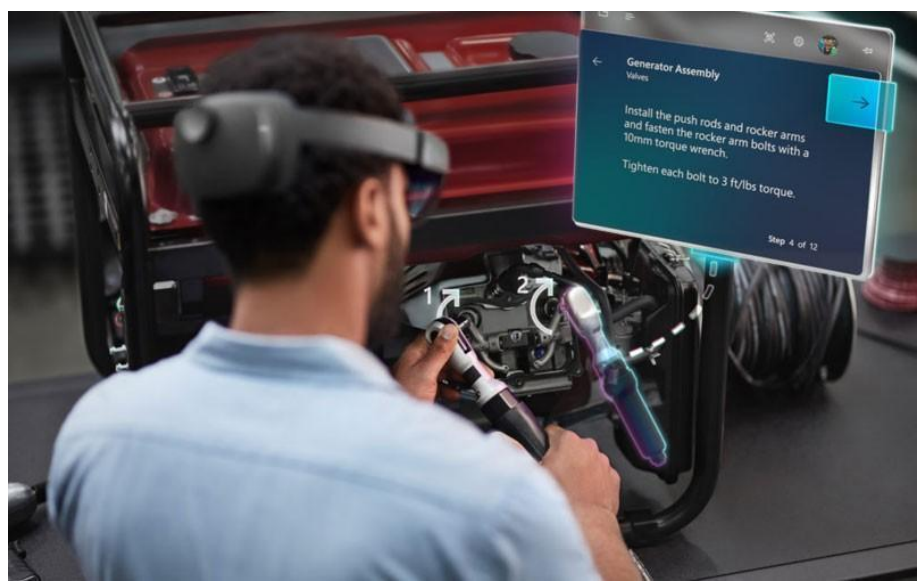

Figura 44: exemplo da utilização do HoloLens 2

\footnotetext{
${ }^{34}$ Disponível em: <https://www.microsoft.com/en-us/hololens/buy>. Acesso em 17 de mar. de 2020.
} 
Lembrando que a Niantic, responsável pelo Pokémon GO, Ingress e o mais recente Harry Potter WU anunciou no ano de 2019 que está desenvolvendo óculos em realidade aumentada para ser utilizados nos jogos. Mais de um século depois da ficção científica, vemos a concretização do que L. Frank Baum especulou.

Outra referência importante e bem mais recente na área de ficção audiovisual é a série britânica Black Mirror, que em 2011 lançou o episódio "The Entire History of You", em que os personagens usavam lentes de contato que realizavam gravações de suas memórias, permitindo rever a qualquer momento por via de uma projeção.

A marca Sony realizou uma patente para uma lente de contato inteligente que capta imagens e vem realizando pesquisas para encontrar materiais possíveis de serem inseridos no corpo dos sujeitos de forma mais orgânica, buscando encontrar possibilidades de sua aplicação.

A Mojo Vision criou o protótipo da Mojo Lens ${ }^{35}$, lentes de contato inteligentes que busca fundir as informações digitais com o mundo real ao redor, "usando microeletrônica e uma pequena tela para compartilhar informações críticas, a Mojo Lens permite que cada usuário seja o melhor possível em qualquer situação" (2020 n.p. tradução nossa).

Em outras palavras vê-se nesse anuncio do produto uma promessa de melhoramento da condição humana sendo um dos focos da empresa desenvolver um conjunto básico de recursos para pessoas que possuem alguma deficiência visual, de forma que as lentes inteligentes podem auxiliar em casos de degeneração de retina ou mesmo outras deficiências mais comuns como miopia e hipermetropia. Há também o aspecto mercadológico para consumidores comuns que poderiam parear as lentes inteligentes com os smartphones, mostrando o conteúdo acessado diretamente nos olhos e não mais nas telas.

Na descrição do site da empresa tem-se que:

As lentes Mojo, por exemplo, podem detectar o texto em um sinal de estrada à distância e exibi-lo claramente. Elas podem ampliar objetos ou projetá-los na parte da retina da pessoa que ainda pode ver bem. As lentes podem ajudar as pessoas a detectar objetos à sua frente, aumentando o contraste entre as tonalidades ou cores dos objetos. As

\footnotetext{
${ }^{35}$ Disponível em: https://www.mojo.vision/mojo-lens. Acesso em 02 de mar. de 2020.
} 
lentes também podem sobrepor linhas gráficas sobre pontos difíceis de ver objetos na visão do usuário. (2020, n.p. - tradução nossa).

Ainda sem data de lançamento as lentes ainda são um protótipo:

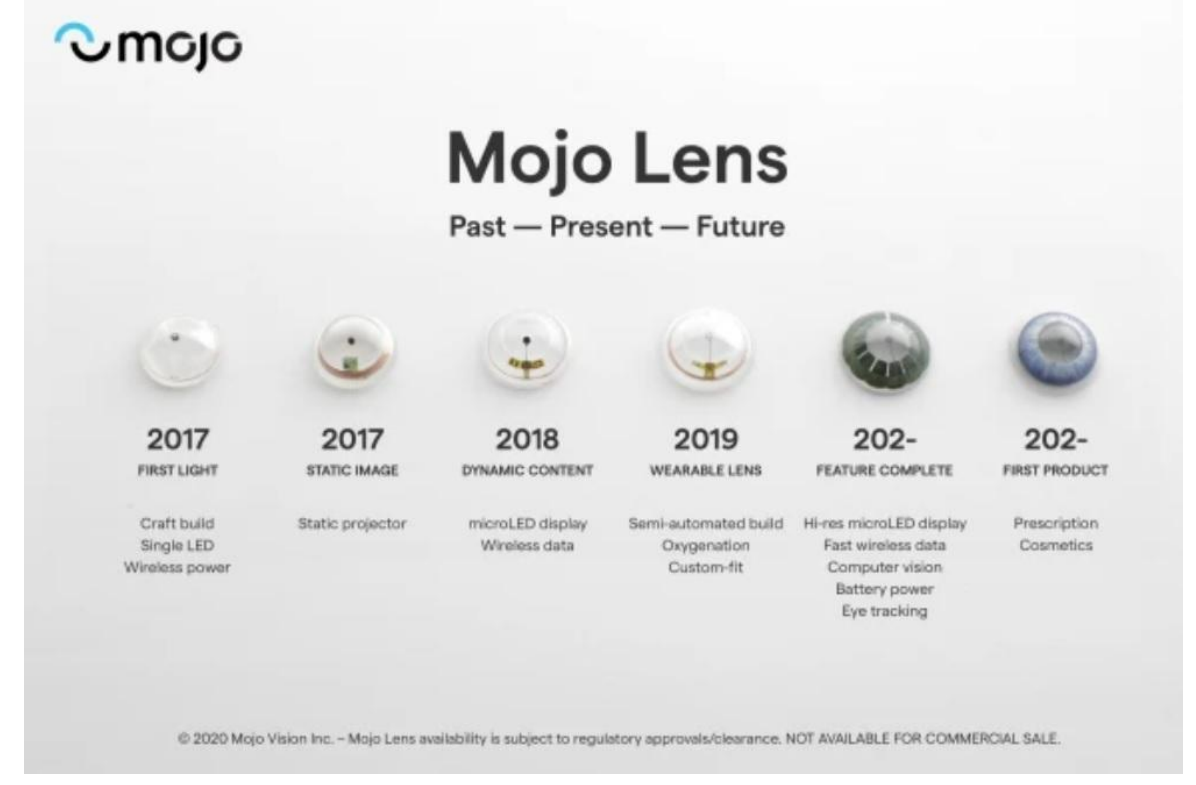

Figura 45: evolução dos protótipos da Mojo Lens

Um time de pesquisadores no MIT, sob orientação de Jeffrey Grossman e Jeehwan $\mathrm{Kim}^{36}$, vem desenvolvendo um grafeno transparente sem silício para poder ser utilizado em vestíveis principalmente como as lentes de contato. Os engenheiros misturam e combinam materiais para criar eletrônicos elásticos, de forma que "os dispositivos da próxima geração serão fabricados com o novo método "descascar e empilhar" que podem incluir chips eletrônicos usados na pele” (CHU, 2020, n.p. tradução nossa).

O objetivo é produzir dispositivos eletrônicos flexíveis e multifuncionais econômicos, chamado de epitaxia remota:

O processo é chamado de "epitaxia remota" e envolve o crescimento
de filmes finos de um material semicondutor em uma bolacha grande
e grossa do mesmo material, que é coberta por uma camada
intermediária de grafeno. Depois que os pesquisadores cultivam um
filme semicondutor, eles podem separá-lo da bolacha coberta de
grafeno e reutilizá-la, o que pode ser caro dependendo do tipo de

${ }^{36}$ Disponível em: http://news.mit.edu/2020/flexible-electronics-stacks-chips-0205. Acesso em 15 de fev. de 2020 . 
material de que é feito. Dessa maneira, a equipe pode copiar e remover qualquer número de filmes semicondutores finos e flexíveis, usando a mesma bolacha subjacente. (CHU, 2020, n.p. - tradução nossa).

Na foto percebe-se a delicadeza e o trabalho minucioso dessa técnica:

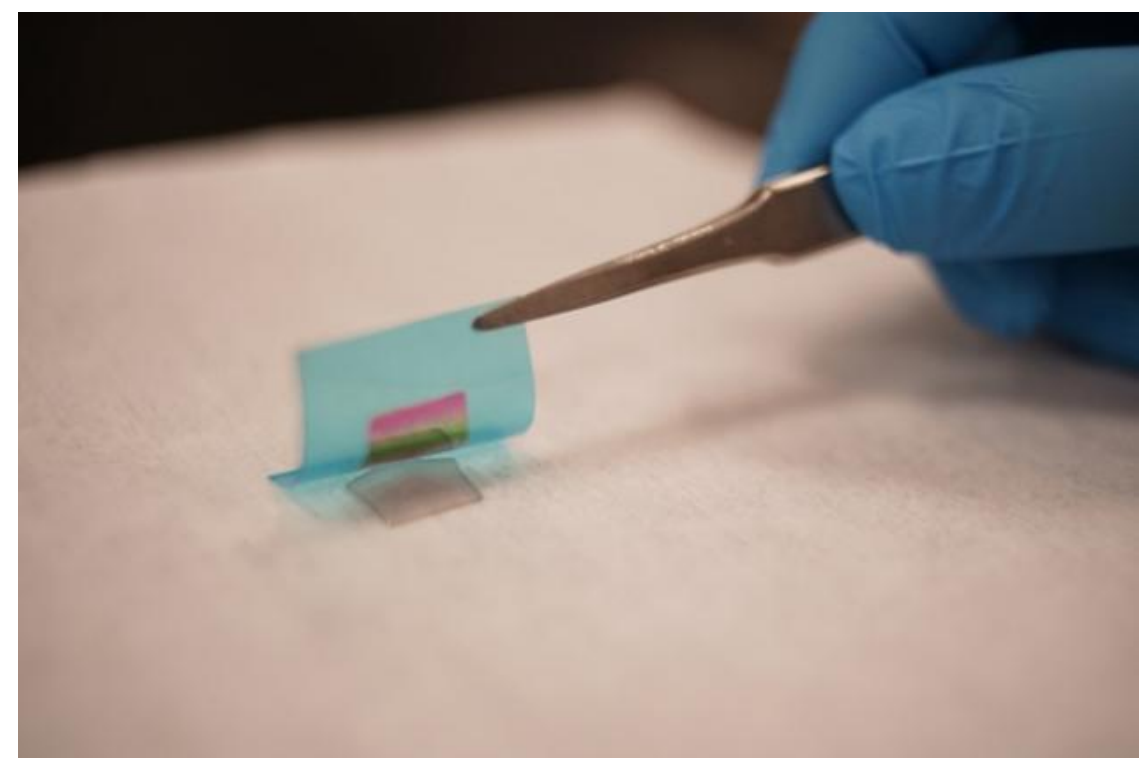

Figura 46: exemplo de epitaxia remota

Lanier comenta que com essa mescla de virtual e real o cérebro tende a aceitar o avatar como seu próprio corpo, sendo que "a única diferença entre o seu corpo e o resto da realidade que você está vivenciando é que você já sabe como controlar o seu corpo, de forma que faz isso de modo automático e subconsciente" (LANIER, 2010, p. 180), de forma que se em uma simulação o sujeito mexer os dedos dos pés, as nuvens também irão se mexer. "Então você começará a sentir como se as nuvens fizessem parte do seu corpo. Todos os elementos da experiência se tornam mais intercambiáveis do que no mundo físico. E tudo isso leva a uma experiência reveladora. O corpo e o restante da realidade deixam de ter uma fronteira fixa" (LANIER, 2010, p. 180).

É possível que a realidade aumentada se torne a tecnologia vestível mais prevalente entre as outras, uma vez que a mescla entre virtual e real é o atrativo dessas possibilidades vestíveis. No caso das lentes teria três objetivos: uma câmera para gravar, um microfone para captar sons e um LCD para projetar as gravações, "agora você pode imaginar um dispositivo fino e flexível feito de camadas que incluem um sensor, 
sistema de computação, bateria, célula solar, para que você possa ter um chip empilhado flexível, autoalimentado e com a Internet das Coisas" (CHU, 2020, n.p. - tradução nossa).

Acerca da Internet das Coisas é possível que se torne total:

Um dia, a internet das coisas se tornará a internet de tudo. Os objetos em nosso mundo poderão sentir e reagir a nós individualmente o tempo todo, de modo que um termostato inteligente se ajustará automaticamente com base na temperatura do seu corpo ou a casa travará automaticamente quando você se deita. Suas roupas também poderão vir com sensores conectados, para que as coisas ao seu redor possam responder aos seus movimentos em tempo real. (PARDES, 2020, n.p. - tradução nossa)

Para Shane (2018), devemos ter muito cuidado com o que pedimos à inteligência artificial, haja vista que se sabe que um algoritmo pode resolver um problema, mas geralmente não sabemos exatamente como. Assim, tudo o que um dispositivo conhece que é o que Shane chama de rede neural, é algo que já estava em seu conjunto de dados de entrada, uma vez que não teria outras informações para trabalhar em cima. Ou seja, “os algoritmos de aprendizado de máquina de hoje são considerados uma forma de inteligência artificial, mas é mais útil pensar neles como algoritmos de previsão" (SHANE, 2018, n.p. - tradução nossa).

Para a autora, a maior preocupação é a confiança total nesses dispositivos, já que podem ser decisões que não entendemos e podem refletir comportamentos tendenciosos dos humanos, tal como as questões problemáticas dos filtros nas redes sociais, em outras palavras:

\footnotetext{
Quando estamos usando algoritmos de aprendizado de máquina, obtemos exatamente o que pedimos - para melhor ou para pior. Por exemplo, um algoritmo que vê decisões de contratação tendenciosas por raça ou sexo predizem decisões tendenciosas de contratação, e um algoritmo que vê viés racial nas decisões de liberdade condicional aprenderá a imitar esse viés ao tomar suas próprias decisões de liberdade condicional. Afinal, não perguntamos a esses algoritmos qual seria a melhor decisão. Apenas pedimos a eles para prever quais decisões os humanos em seus dados de treinamento teriam tomado. (SHANE, 2018, n.p. - tradução nossa)
}

Uma leitura complementar acerca do que seriam esses objetos inteligentes vem do motivo pelo qual recebem esse nome, que se dá não somente pelas vantagens que 
oferecem à quem os utiliza, mas por quanto podem integrar a vida às rotinas 24/7 de forma mais completa, sendo também um dispositivo de controle. Além do risco eminente que Shane argumenta, de entrar em um caminho nebuloso dependente de algoritmos, a "internet das coisas produz novos fantasmas. As coisas que antigamente eram mudas começam, agora, a falar" (HAN, 2018, p. 97). Portanto, realizam a consumação dessa sociedade do panóptico, do controle digital, enviando, sem pausa, “informações sobre o nosso fazer o nosso deixar de fazer” (HAN, 2018, p. 127).

O que culmina em um exagero da vigilância, do panóptico digital:

Os algoritmos se empanturram de dados sobre você a cada segundo. Em que tipos de link você clica? Quais são os vídeos que vê até o fim? Com que rapidez pula de uma coisa a outra? Onde você está quando faz essas coisas? Com quem está se conectando pessoalmente e online? Quais são as suas expressões faciais? Como o tom da sua pele muda em diferentes situações? O que você estava fazendo pouco antes de decidir comprar ou não alguma coisa? Você vota ou se abstém? Todas essas informações e muitas outras têm sido comparadas a leituras semelhantes sobre a vida de milhões por meio de uma espionagem maciça. Os algoritmos correlacionam o que você faz com o que quase todas as outras pessoas têm feito. Os algoritmos não entendem você de fato, mas existe poder nos números, sobretudo nos grandes. (LANIER, 2018, p. 13)

A questão da privacidade e da vigilância é uma inquietude presente em várias falas, uma vez que será uma quantidade de dados que nem ainda se pode contabilizar, pois não há escala no momento. Para Kelly, "será a maior conquista da humanidade, criando novos níveis de riqueza, novos problemas sociais e inúmeras oportunidades para bilhões de pessoas. Ainda não há especialistas para fazer este mundo; você não está atrasado" (KELLY, 2019, n.p. - tradução nossa).

É mais um meio de publicidade e é perceptível em como o modo de anunciar produtos e realizar compras foi integrado às redes de forma personalizada:

Os anunciantes costumavam ter uma chance limitada de fazer uma abordagem de venda, e essa abordagem podia ser sorrateira e irritante, mas era passageira. Além disso, muita gente via o mesmo anúncio veiculado na TV ou impresso em jornais e revistas; ele não era adaptado para cada indivíduo. A maior diferença é que você não era monitorado e avaliado o tempo todo para que pudessem alimentá-lo com estímulos otimizados de maneira dinâmica — sejam eles "conteúdo" ou anúncios — de forma a alterá-lo e conseguir seu engajamento. Agora, todos que estão nas redes sociais recebem estímulos individualizados, continuamente ajustados, sem trégua; é só estar usando o smartphone. O que antes podia ser chamado de 
propaganda deve agora ser entendido como uma modificação de comportamento permanente e em escala gigantesca. (LANIER, 2018, p. 13)

Essa seria uma grande crítica de Lanier, do quanto a tecnologia sustenta modelos de negócios bastante nocivos e que deveríamos tentar alterar essa lógica, "temos que tentar, senão seremos obrigados a jogar fora todo um universo da tecnologia digital" (LANIER, 2018, p. 33).

Um dos criadores da revista Wired $^{37}$, Kelly (2019) aponta que a realidade aumentada desencadeará a próxima grande plataforma tecnológica, chamada de Mirrorworld, na qual "nossa realidade física se fundirá com o universo digital" (KELLY, 2019 - tradução nossa). Um ecossistema de realidade estendida que combina realidade aumentada, realidade virtual e inteligência artificial:

\begin{abstract}
Mirrorworld (o mundo dos espelhos) ainda não existe completamente, mas está chegando. Em breve, todos os lugares e coisas do mundo real - todas as ruas, postes, prédios e salas - terão seu gêmeo digital em tamanho real no mundo dos espelhos. Por enquanto, apenas pequenas manchas do mundo dos espelhos são visíveis nos aparelhos de R.A. Peça por peça, esses fragmentos virtuais estão sendo unidos para formar um lugar compartilhado e persistente que será paralelo ao mundo real. (KELLY, 2019, n.p. - tradução nossa)
\end{abstract}

Por exemplo, com as ruas no Google Maps, não serão imagens planas, no Mirrorworld terão volume, texturas, simularão a sensação real de uma rua e "refletirá não apenas a aparência de algo, mas seu contexto, significado e função. Vamos interagir com ele, manipulá-lo e experimentá-lo como fazemos no mundo real" (KELLY, 2019, n.p. - tradução nossa).

A inteligência artificial é essencial dentro desse modelo de futuro próximo e Kelly afirma que já existem vislumbres do que seria esse mundo, tal como o jogo Pokémon GO. "Talvez nada tenha provado que o casamento entre o virtual e o físico seja irresistível melhor que o Pokémon GO, um jogo que imerge personagens obviamente virtuais na realidade do exterior" (KELLY, 2019 n.p. - tradução nossa).

É a linguagem da realidade aumentada que sustenta o Mirrorworld:

TUDO CONECTADO à internet estará conectado ao mirrorworld. E qualquer coisa conectada ao mundo dos espelhos verá e será vista por tudo o mais neste ambiente interconectado. Relógios detectam

\footnotetext{
37 Disponível em https://www.wired.com/story/mirrorworld-ar-next-big-tech-platform/. Acesso em 24 de jan. de 2020 .
} 
cadeiras; cadeiras detectarão planilhas; os óculos detectam relógios, mesmo debaixo de uma manga; os tablets verão o interior de uma turbina; turbinas verão trabalhadores à sua volta. (KELLY, 2019, n.p. - tradução nossa)

Um aspecto importante desse mundo será como as pessoas serão afetadas em nível pessoal:

\begin{abstract}
Sabemos que haverá graves efeitos fisiológicos e psicológicos da habitação em mundos duplos; já aprendemos isso com a experiência que vivemos no ciberespaço e nas realidades virtuais. Mas não sabemos quais serão esses efeitos, muito menos como nos preparar ou evitá-los. Nem sequer sabemos exatamente o mecanismo cognitivo que faz a ilusão de RA funcionar em primeiro lugar. (KELLY, 2019, n.p. - tradução nossa)
\end{abstract}

Nessa previsão não haverá mais realmente nenhuma distinção entre o que é realidade aumentada e a própria realidade, em que todos os objetos e redes poderão ser observados em RA. Não haverá um borramento das fronteiras, elas não existirão, ou seja, os sujeitos serão organismos informacionais e a experiência de uma realidade hiperconectada sem oposição entre estar online ou offline, o Onlife - será o paradigma da sociedade.

Além disso, o 24/7 se tornará mais intenso, pois o tempo fica sem demarcação, sem sequência e recorrência e a atenção se torna uma cobrança ininterrupta, em que se demanda do sujeito uma apreensão contínua, que vem em múltiplas camadas, inteligência artificial, realidade aumentada e a própria realidade.

Para Kelly os efeitos serão dos mais variados e pode-se relacionar com o que Lanier chama de comunicação pós-simbólica, que se trata de um efeito fisiológico e psicológico até então inédito:

Por exemplo, em vez de dizer "Estou com fome, vamos pegar uns caranguejos", você poderia simular sua própria transparência de forma que seus amigos pudessem ver seu estômago vazio, ou poderia se transformar em um videogame com o tema de uma caça a caranguejos de forma que você e seus amigos pudessem praticar um pouco antes da verdadeira caçada. Chamo essa possibilidade de "comunicação pós-simbólica”. Pode ser difícil pensar nesses termos, mas considero o exercício extremamente empolgante. $\mathrm{Eu}$ não sugeriria uma aniquilação da linguagem como a conhecemos - a comunicação simbólica continuaria a existir - mas isso levaria a uma vívida expansão do significado. Essa é uma extraordinária transformação que um dia as pessoas poderiam vivenciar. Nesse caso, teríamos a opção de eliminar o "intermediário" dos símbolos e criar diretamente uma experiência compartilhada. Um tipo fluido de concretude poderia se provar mais expressivo do que a abstração. (LANIER, 2010, p. 183) 
O questionamento ético acerca da tecnologia engloba todos os exemplos trazidos aqui, haja vista que se trata de um campo ainda em desenvolvimento e, portanto, muitas normas, expectativas, parâmetros e regras ainda estão sendo delimitados.

Dentro da ética dos dados, a ética dos algoritmos e a ética das práticas, Floridi (2017) propõe o termo infraética:

\begin{abstract}
Estamos lidando com ações imorais / morais e facilitadores ainda não éticos de tais ações imorais / morais. A infraética também não deve ser entendida, conceitualmente, em termos de um tipo de discurso de segunda ordem ou um discurso metaético sobre ética, porque é a estrutura ainda não ética que pode facilitar ou dificultar avaliações, decisões, ações ou situações que são morais ou imorais. Ao mesmo tempo, seria errado pensar também que uma infraética é eticamente neutra ou simplesmente tem um uso dual ético, porque seu uso duplo é sempre orientado. (FLORIDI, 2017, p. 2 - tradução nossa)
\end{abstract}

Eticamente lembra-se que nunca é neutra "na filosofia da tecnologia, é agora comumente acordado que o design - em qualquer contexto, inclusive a sociedade nunca é eticamente neutro, mas sempre incorpora alguns valores, de forma implícita ou implícita" (FLORIDI, 2017, p. 2 - tradução nossa).

Assim, a discussão circunda sobre a combinação coerente entre valores moralmente bons, tal como direitos civis, o que tem se mostrado como grande desafio da quarta revolução:

\footnotetext{
É por isso que é difícil alcançar um equilíbrio entre segurança e privacidade, por exemplo, a menos que esclareçamos primeiro se estamos lidando com uma tensão dentro da ética (segurança e privacidade como direitos morais), dentro da infraética (ambos são entendidos como ainda não éticos facilitadores), ou entre infraética (segurança) e ética (privacidade), como suspeito. (FLORIDI, 2017, p. 3 - tradução nossa)
}

A ARL (Association of Research Libraries) do Canadá e dos Estados Unidos, publicaram em 2019 duas pesquisas acerca das literacias dos dados e da infraética em que Johnson (2019) sustenta alguns questionamentos ainda sem resposta, mas que devem receber deliberação de alguns níveis práticos e regulatórios, tais como:

Que quantidade de dados é muito para uma entidade possuir? Os conjuntos de dados devem ser classificados como públicos de forma a evitar sua monetização? Se a monetização de dados representa um caminho viável para resultados éticos no futuro da humanidade, os 
indivíduos deveriam se beneficiar financeiramente do uso de seus dados? (JOHNSON, 2019, p. 19 - tradução nossa)

Na sociedade tecnocrática, a informação seria como o petróleo uma categoria de ativo absolutamente valioso e que ainda navega por águas bastante nebulosas eticamente falando. $\mathrm{O}$ que pontua como uma boa possibilidade em vista é que esses desafios estão exigindo de instituições e dos sujeitos a adotarem novas formas de liderança na área das humanidades:

Depois de décadas de preocupações de que a popularidade dos paradigmas de ciência e tecnologia ameaçassem a aprendizagem e os estudos humanísticos, agora está se tornando evidente que oportunidades únicas estão surgindo para demonstrar por que a experiência humanística e as considerações sobre a condição humana são essenciais para o futuro da humanidade na era tecnológica. (JOHNSON, 2019, p. 25 - tradução nossa)

\section{2) Realidade aumentada no futuro da educação: o aspecto social das literacias}

Com a pandemia de 2020, a educação foi forçosamente obrigada a se transformar por completo. Focar no ensino remoto no âmbito virtual e foi uma importante solução emergencial. Algumas iniciativas já existiam e foram resinificadas, tal como plataformas que forneciam cursos totalmente online e que receberam um aumento do número de interessados e outros casos como das escolas que tiveram que se adaptar para o ensino utilizando dispositivos totalmente digitais.

Um artigo da revista Wired relatou que a pandemia estimulou o que chama de infodêmico ou disseminação de informações prejudiciais, mas que, no entanto, é também nesse mesmo momento de crise que grupos e indivíduos estão gerando e disseminando conhecimentos de forma colaborativa "numa corrida para criar e compartilhar recursos para enfrentar os desafios da pandemia, as comunidades inauguraram uma era de ouro de um conceito econômico pouco conhecido: o conhecimento comum" (CHYI, 2020, n.p. - tradução nossa). 
Um exemplo dessa iniciativa é a de reconstrução de espaços locais no Minecraft, com alunos reconstruindo suas universidades, de forma que "ao preservar suas memórias pessoais em histórias digitais, esses espaços funcionam tanto como uma maneira de os alunos processarem a perda repentina de uma comunidade no campus, como uma maneira de compartilhar conhecimento cultural" (CHYI, 2020, n.p. tradução nossa). Além disso, milhares de projetos estão liberando seus códigos abertos, com o código-fonte e as documentações disponíveis de forma gratuita para disseminar seu uso.

Entende-se assim que:

Os indivíduos têm o poder de se tornar co-criadores, coprodutores e co-distribuidores de informações para o benefício de suas comunidades. A necessidade de conhecimento local nessa pandemia, combinada ao uso de locais digitais como o Google Sheets ou Minecraft, permite que indivíduos participem da produção de conhecimento quando normalmente não o fariam. As comunidades às quais pertencem também são fortalecidas e apoiadas. (CHYI, 2020, n.p. - tradução nossa)

No meio de tanta oportunização de conhecimento, a utilização da realidade aumentada na educação mais uma camada, em que não há divisão entre o que é ensino online e virtual e o que é ensino no âmbito real, o rompimento completo do que se entende por sala de aula comumente. Com a utilização ininterrupta da tecnologia no cotidiano, a educação não pode ser excluída desse processo, de forma que existem movimentos em escolas de ensino básico e em universidades que vem adotando a utilização de computadores, tablets, smartphones e quadros inteligentes nas aulas.

Um primeiro ponto a ser destacado é o uso dos materiais didáticos e educacionais, que podem ser completamente transformados pelo uso da realidade aumentada, de forma a desenvolver um conteúdo mais imersivo que cria uma camada em terceira dimensão, que vai além da produção textual para uma sinergia entre conteúdos escritos e imagéticos. Aqui destacamos a importância da visualidade e como a realidade aumentada está ancorada no sentido da visão. 
De acordo com Bower, Lee e Dalgarno (2017), alguns indicativos já são assegurados a respeito da realidade aumentada no campo da pesquisa científica, são eles:

- Os mundos virtuais podem ser usados para facilitar a aprendizagem colaborativa sincronizada entre alunos remotos ou remotos e suas características acreditam ter o potencial para dar origem a altos níveis de co-presença entre estes estudantes.

- Espaços virtuais aumentados (físicos) e aumentados podem ser combinados para criar um ambiente de aprendizagem de "realidade combinada" que permite aos participantes interagir dentro e através dos espaços. (BOWER; LEE; DALGARNO, 2017, p. 408 - tradução nossa)

A definição de ambiente colaborativo de realidade mista entende que é um ambiente "que reúne participantes em realidade aumentada e espaços aumentados de virtualidade, permitindo que eles interajam dentro e através dos espaços através da projeção de áudio ao vivo e/ou informações visuais de cada espaço no outro" (BOWER; LEE; DALGARNO, 2017, p. 409 - tradução nossa).

Para os autores, utilizar dessa tecnologia no espaço físico de uma sala de aula tem o propósito de permitir que alunos remotos participem ao vivo da aula e ao mesmo tempo, possibilitar que os alunos presentes e o professor interajam com os outros alunos. De forma mais imersa e que permita maior participação e foco de atenção, uma vez que em um ambiente digital há a excesso de informação e é necessária uma maior dedicação e disciplina.

Em termos técnicos há toda uma organização logística para a realização de uma experiência educacional em realidade aumentada, o que por razões de orçamento e/ou acessibilidade pode ser um impeditivo para a efetividade desse modelo de ação.

No entanto, o que parece ser a chave mais importante é a questão da literacia, retomando Passarelli (2010) em que esse modelo de experiência abrange as competências do usuário para explorar o potencial multimídia, de forma que "os letrados da sociedade em rede são aqueles capazes de ler, escrever, interagir, comunicar-se por meio dessa linguagem multimídia, reconhecendo práticas sociais e gêneros textuais que envolvem cada elemento dessa interface” (PASSARELLI, 2010, p. 73). 
Para Bower, Lee e Dalgarno, os principais objetivos de realizar um estudo dessa forma é articular quais são as vantagens e desvantagens associadas ao uso da virtualidade na educação e possibilitar um alto nível de aprendizado na capacidade dos usos da tecnologia em sala de aula.

Apontam assim alguns indicadores pedagógicos, tecnológicos e logísticos que apoiaram a experiência, tais como alto engajamento, aprendizado ativo, possível escutar os alunos remotos e compartilhar conteúdo, possível comunicar normalmente com os alunos remotos, na linguagem corporal e voz e trabalhar em grupo e ter oportunidade de interagir.

Entre os indicadores que restringiram destacam-se as dificuldades com o atraso do áudio, dificuldade de comunicação com os outros alunos remotos, dificuldade para determinar quem estava falando, saber a hora para falar ou não, impossibilidade de enxergar as pessoas por trás do avatar e distração ao focar nos alunos remotos. (BOWER; LEE; DALGARNO, 2017 p. 423 - tradução nossa).

Não somente nessas experiências de sala de aula com R.A. mas em muitas outras plataformas como Google Meets ou Zoom foi percebido como a qualidade da internet pode oscilar e o mesmo acontece com o áudio, o que faz com que seja realmente um fator impeditivo, o que nos leva a questão da presença.

O que é um grande diferencial da utilização da R.A. é o possível senso de presença e conexão com os outros, apesar da presença física ser dispersa, há uma tentativa da sensação de estar ali presente. Os autores entendem que com essa configuração tecnológica necessária para estabelecer experiências com esse alcance, de criar um ambiente de aprendizagem de realidade mista é atualmente irrealista para classes regulares.

Há sim uma nova ecologia da aprendizagem e do ensino com características próprias, as quais se destacam:

\footnotetext{
a) Permanência: os documentos podem permanecer reproduzidos em múltiplos suportes;

b) acessibilidade: os dados são acessíveis a partir de várias fontes;

c) rapidez: pode-se obter qualquer informação de forma instantânea, a qualquer momento;
} 
d) interatividade: o utilizador mantém uma relação interativa e biunívoca;

e) atividades situadas: a aprendizagem integra-se na vida diária; os problemas encontrados e o conhecimento requerido estão presentes de forma natural e autêntica;

f) adaptabilidade: os alunos terão a informação apropriada às suas necessidades pessoais, de modo correto e no tempo e no lugar corretos. (CADAVIECO; GOULÃO; TAMARGO, 2014, p. 40 tradução nossa)

A utilização ininterrupta dos dispositivos móveis não pode ser ignorada, e nessa direção, estudos têm sido realizados na investigação de agregar esses dispositivos aos espaços, como por exemplo, professores que se utilizam smartphones para trabalharem o conteúdo didático em conjunto com seus alunos.

O que tem ainda mais potencial educacional compartilhado são os aplicativos que permitem aos usuários definirem seus próprios gatilhos e sobreposições, "os conteúdos multimídia empregados na realidade aumentada podem contemplar elementos tais como imagens, mapas, hiperlinks, vídeos, textos, jogos e músicas" (GALVÃO, CARMONA, RICARTE, 2018, p. 111).

A ativação de capacidades cognitivas e contextualização do que viram no ambiente real permite que os alunos desenvolvam uma relação mais ativa com o ambiente ao redor. De forma que a sua utilização em salas de aula tem mostrado um aprendizado mais inclusivo e um aumento da motivação dos estudantes. (BOWER, 2016, p. 4 - tradução nossa).

O uso de um sistema em realidade aumentada produziu efeitos positivos sobre as atitudes relativamente ao aprendizado dos alunos:

Uma oportunidade pedagógica chave da realidade aumentada é a capacidade de redimensionar objetos virtuais, de moléculas a corpos planetários, permitindo aos estudantes entender através da manipulação as propriedades e relações dos objetos que são ou muito pequenos ou muito grandes para serem examinados de forma eficaz em suas rotinas diárias (BOWER, 2016, p. 5 - tradução nossa).

Embora a utilização de outras linguagens no ambiente educacional também sejam importantes, a representação de conceitos espaciais e temporais em realidade aumentada são "como a vantagem extra de contextualizando a relação entre o objeto 
virtual e o mundo real" (BOWER, 2016, p. 5 - tradução nossa). E podem melhorar a variedade de abordagens pedagógicas, algumas como aprendizagem construtivista, aprendizagem situada, aprendizagem baseada em jogos e aprendizagem baseada em perguntas. (BOWER, 2016, p. 7 - tradução nossa)

Assim,

\begin{abstract}
A RA tem a capacidade, por exemplo, de fornecer contexto para coisas do mundo real (pense: apontando sua câmera para uma pintura e aprendendo mais sobre sua história). Para os jovens, a interatividade da realidade aumentada pode ajudar a tornar interessantes os tópicos chatos (pense: matemática). Atualmente, é um desafio para as escolas ou programas após a escola oferecer AR como parte de um currículo geral. (WATERCUTTER, 2019, n.p. - tradução nossa)
\end{abstract}

No entanto, apesar de iniciativas interessantes e inovadoras, há uma crítica que entende de forma mais negativa a realidade aumentada, tal como:

\begin{abstract}
A realidade aumentada pode ser uma forma de escapismo por breves momentos ou uma fuga daquilo que conhecemos como vida real. Também se alega que os benefícios da realidade aumentada são mais discutidos pelo setor de marketing empresarial de empresas criadoras de realidade aumentada e que o cenário geral vislumbra uma aceitação pacífica dessa tecnologia pelas pessoas, sem considerar suas vontades ou os potenciais riscos ainda desconhecidos. (GALVÃO, CARMONA, RICARTE, 2018, p. 111)
\end{abstract}

Sendo algumas barreiras apontadas como significativas para a utilização bemsucedida da realidade aumentada de forma pedagógica como o conhecimento técnico associado ao desenvolvimento de materiais, uma vez que "os professores muitas vezes não estão bem equipados ou treinados para lidar com as questões e problemas técnicos que podem surgir” (BOWER, 2016, p. 7 - tradução nossa). Não cabe apenas ao professor essa responsabilidade, é necessário um nível alto de apoio institucional para garantir que a tecnologia seja utilizada da melhor forma e não de forma superficial e improdutiva. Ou seja, o aprendizado da literacia precisa ser estrutural: pelos alunos, pela equipe, pelos professores e pelas instituições.

Outra questão bastante relevante é o quanto a dedicação à educação remota traz a reboque uma série de desigualdades sociais baseadas no acesso, "algumas das preocupações sobre como a educação on-line amplia a desigualdade e fornece conteúdo 
experimental mal podem ser atenuadas por meio de algumas instruções da sala de aula" (REMTULLA, 2020, n.p. - tradução nossa).

Tal como é perceptível na pesquisa sobre o uso das tecnologias da informação e comunicação (TIC), realizada no ano 2019 pelo Centro Regional de Estudos para o Desenvolvimento da Sociedade da Informação $\left(\right.$ Cetic.br $\left.{ }^{38}\right)$, que ajuda a construir um panorama geral de como se dá o uso das tecnologias no Brasil, doa quais destaca-se os relatórios TIC Educação e TIC Domicílios.

Por exemplo, sobre o acesso à internet nos domicílios brasileiros há indicação de que o acesso à internet na proporção urbana é maior e há uma grande diferença entre a classe A e classe DE, já que 20 milhões de domicílios não possuem internet (28\%) e domicílios com internet passam dos 50\% na área rural.

No gráfico abaixo fica evidente a alta utilização dos alunos de escolas urbanas.

\section{A5} ALUNOS DE ESCOLAS URBANAS, USO DE REDES SOCIAIS EM ATIVIDADES ESCOLARES

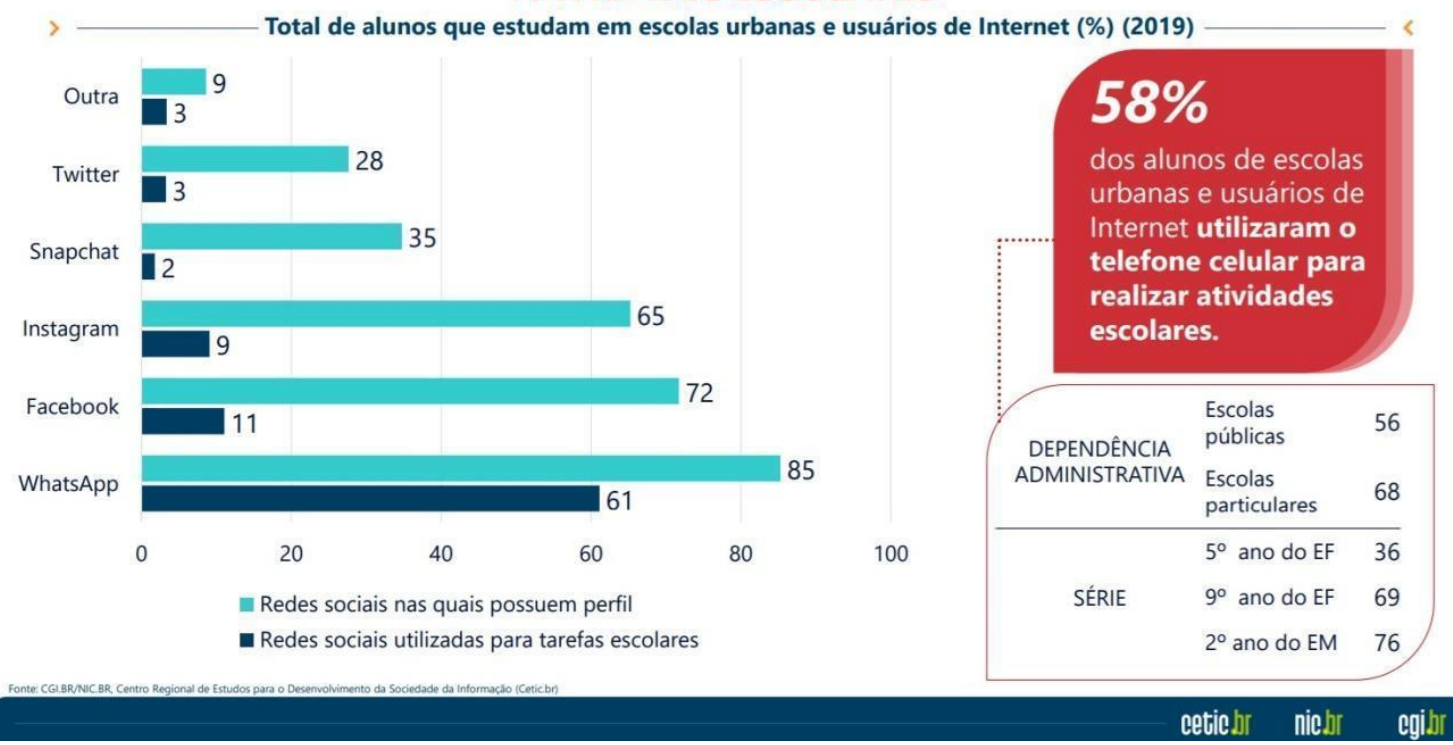

Figura 47: Pesquisa sobre o uso das tecnologias de informação e comunicação - TIC Educação 2019

\footnotetext{
${ }^{38}$ CGI.br/NIC.br, Centro Regional de Estudos para o Desenvolvimento da Sociedade da Informação. Disponível em: https://cetic.br/media/analises/tic_educacao_2019_coletiva_imprensa.pdf. Acesso em 2 de jul. de 2020.
} 
Há uma redução da presença de computadores nos domicílios, um a cada quatro brasileiros não usa a internet sendo um número de 47 milhões de não usuários. Assim, tem-se 134 milhões usuários de Internet (74\%) com uma diferença entre ambiente rural e urbano, em que usuários de internet passam dos 50\% na área rural e nas classes DE. O smartphone é o dispositivo mais usado e 58\% acessam a Internet somente pelo celular. Novamente percebe-se a diferença gritante entre as classes A e DE como fica evidente abaixo.

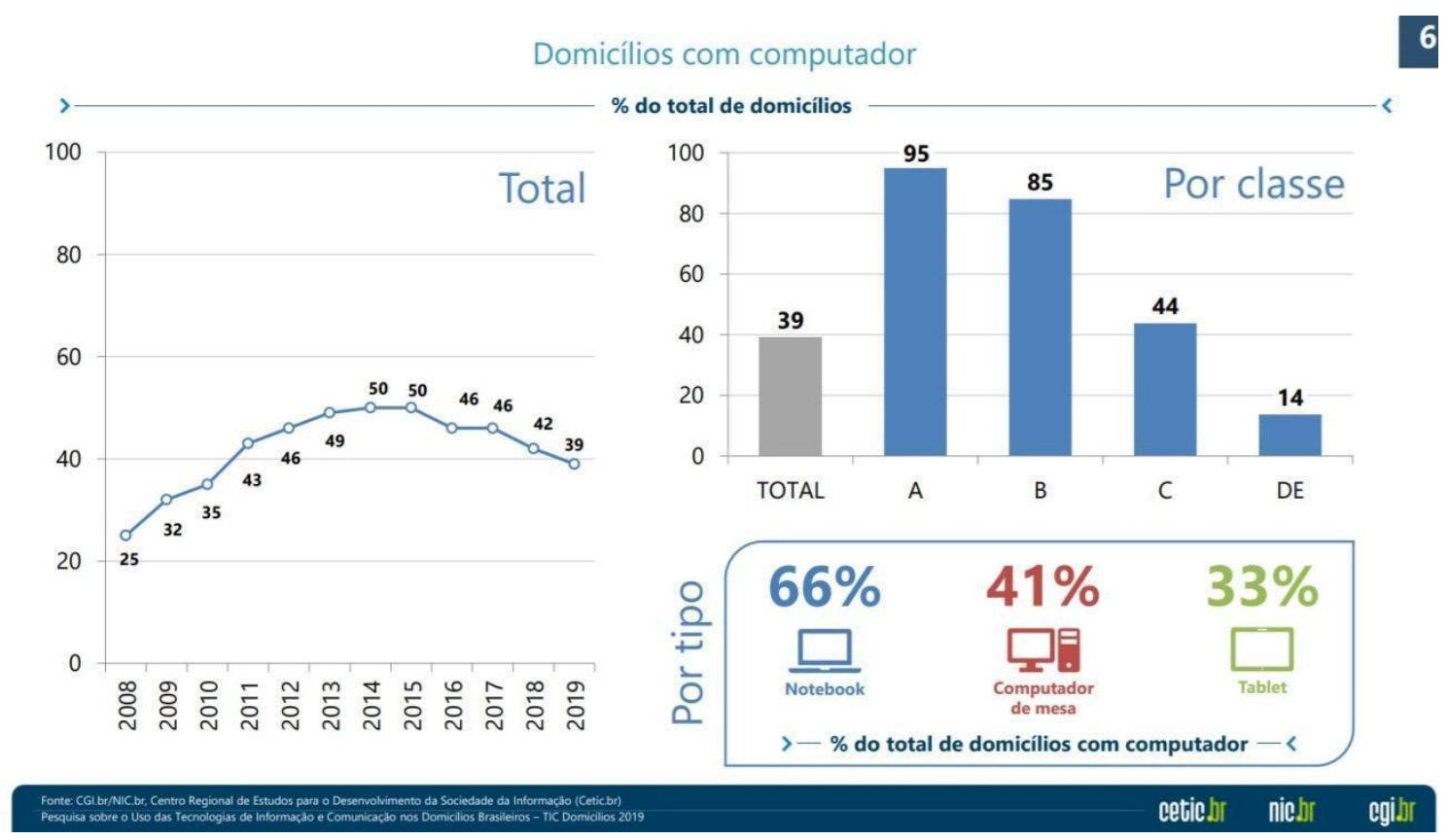

Figura 48: Pesquisa sobre o uso das tecnologias de informação e comunicação nos domicílios brasileiros TIC Domicílios 2019

Mostra-se evidente o quanto a questão do acesso à internet evidencia a grande desigualdade social no Brasil o que faz com que esse fator tenha que ser levado em consideração quando se fala de educação e principalmente de educação nos dispositivos de R.A. pensando o quanto isso ainda está distante de ser colocado em prática no país. 


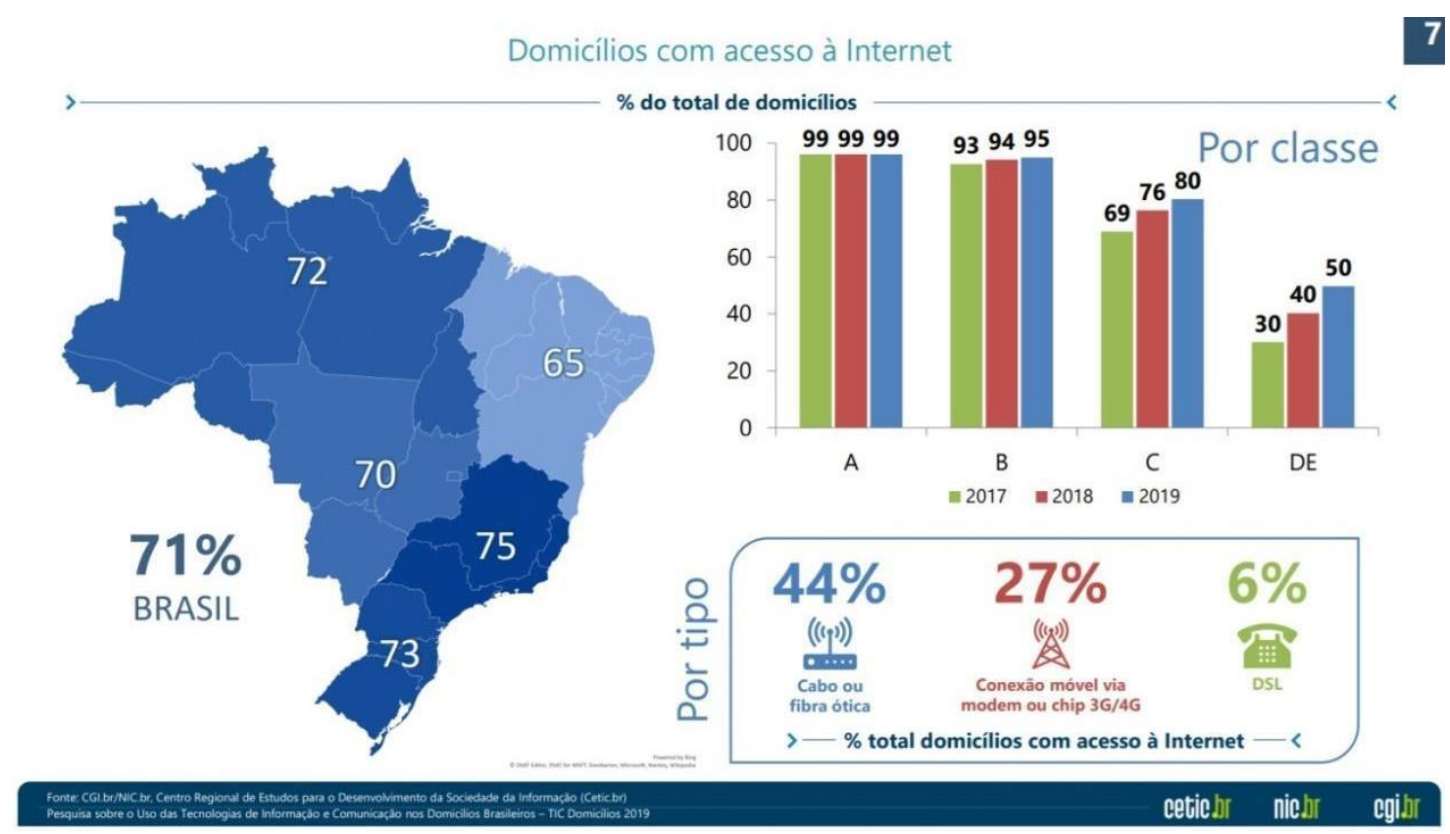

Figura 49: Pesquisa sobre o uso das tecnologias de informação e comunicação nos domicílios brasileiros TIC Domicílios 2019

Assim como a preocupação com o acesso dos alunos, é importante também pensar sobre o papel dos professores que também precisam de formação específica nas literacias considerando o quanto isso altera a atenção dos alunos e dos próprios, buscando maneiras criativas de se manterem engajados, sendo a realidade aumentada uma delas, "o aprendizado híbrido avança três elementos críticos para o ensino superior: flexibilidade, engajamento e aprendizado" (REMTULLA, 2020, n.p. - tradução nossa).

Assim, uma possibilidade intermediária seria o aprendizado combinado, que "promove as conexões vitais da sala de aula que os alunos e os professores valorizam, além de fornecer novos modos de envolvimento" comprovando dessa forma a eficácia dos componentes online e estabelecendo as conexões humanas desenvolvidas apenas pessoalmente, "as ferramentas digitais podem criar um senso de comunidade, relaxando as formalidades de uma sala de aula tradicional e reduzindo a hierarquia" (REMTULLA, 2020, n.p. - tradução nossa).

A escala que isso vai tomar e a forma como irão produzir a subjetividade pedagógica ainda está no campo da expectativa e da sondagem, pois ainda é um desafio saber como será a relação entre os atores humanos e não humanos no âmbito da educação. 
De acordo com Goode (2019) ainda é cedo pedagogicamente para saber o quanto aprendemos as coisas através da realidade aumentada:

O RA carece de totalidade por definição - diferentemente da VR, ela melhora o mundo real, mas não o substitui - e é difícil dizer o que isso significa para a retenção de memória, diz Michael Tarr, pesquisador de ciências cognitivas da Universidade Carnegie Mellon. "Há uma diferença entre as respostas emocionais e viscerais que acontecem quando algo é experimentado como um evento ou coisa real e quando algo é experimentado como uma implementação digital ou pictórica de algo", diz ele. (GOODE, 2019 - tradução nossa) 


\section{CONSIDERAÇÕES FINAIS}

A história não se dá de forma linear nem tampouco homogênea e a tecnologia é sempre um fator de alteração da lógica social e política da humanidade. Sejam tecnologias para construções, agricultura, novos instrumentos técnicos, seja a prensa de Gutenberg ou trem a vapor, são modificações na constituição da sociedade em diferentes camadas, estamos constantemente permeados pelas extensões de McLuhan ou instrumentos, máquinas e aparelhos de Flusser.

Assim, realizamos nessa pesquisa uma análise conjuntural da utilização da tecnologia digital, especialmente da realidade aumentada, e um mapeamento de tendências em um futuro possível da sua utilização, que será um dos maiores investimentos tanto no aspecto econômico quanto de alteração da vida, o chamado mirrorworld. Foi um esforço de mapear e compreender esses usos e o como são potencialidades em todos os campos, seja na educação, na arte e nos videogames.

Com essa pesquisa bibliográfica se delineou o quanto as relações entre atores humanos e não humanos não são neutras nem tampouco sem fricção, pelo contrário, são permeadas por diversas conexões e interesses maiores que os usuários.

Assim, buscamos demonstrar baseado em teorias acerca do contemporâneo hiperconectado o quanto essa visão utópica da tecnologia, floreada e democratizada, na verdade nunca se concretizou e esse modelo de aldeia global no sistema 24/7 vem acentuando desigualdades sociais e disputas políticas decorrentes do acesso às tecnologias. Exemplo disso é a tentativa do presidente dos Estados Unidos, Trump, bloquear a rede social chinesa Tiktok, ação que não é pela rede em si, mas derivada de uma relação sociopolítica e econômica.

Ao analisarmos os filtros nas redes sociais, trabalhos nas artes visuais, aplicativos e os videogames, com estudo de caso do Pokémon GO, mapeamos de que modo a utilização da realidade aumentada altera a percepção visual de quem a utiliza e em como isso só vai ser potencializado nos próximos anos, com as tecnologias vestíveis, criando um completo embaçamento entre o que é real e virtual. Entendendo que essas mudanças vão nos transformar como sujeitos e seres sociais, em como nos relacionamos com as imagens e com a visualidade e até entre nós mesmos. 
É importante ressaltar que o processo de desenvolvimento acadêmico não se deu de forma uniforme. Do projeto inicial até sua estrutura final muito se transformou, muitos conceitos foram considerados, outros retirados completamente e o delineamento de uma pesquisa bibliográfica foi em cima de muitos questionamentos.

Um dos interesses iniciais se tratava da realização de uma pesquisa de campo com jovens da geração $\mathrm{Z}$ de diferentes classes sociais para entender quais suas interpretações diante da realidade aumentada. Por motivos diversos como a dificuldade de realização devido ao isolamento social e também o tamanho da amostra ser volumoso, isso acabou por não se concretizando, porém ainda há interesse em coletar esses dados.

Outra ação que ficou a ser desenvolvida foi realizar um roteiro em realidade aumentada em conjunto com esses jovens, um aplicativo ou uma ação poética, de forma a entender como se dá realmente na prática a feitura da técnica e da construção de uma narrativa.

A artista Hilma Af Klint disse "descrevo o caminho enquanto o percorro", e acreditamos que esse olhar poético da ciência em ação foi o que aconteceu ao longo desses dois anos de pesquisa, com adaptações e novas aberturas de investigação. Assim, caminhou-se para outra estratégia epistemológica que delineou a análise dos dispositivos em si e suas mediações, como foi realizado no caso específico do Pokémon GO como um marco temporal da disseminação da realidade aumentada.

Quanto ao estudo do campo da indústria dos videogames, apesar de não ser o foco da pesquisa, alguns comentários são importantes de serem tecidos, em como ainda há muita diferença de tratamento e representatividade entre homens e mulheres, em que ficou bastante evidente a diferença dos números entre os gamers e profissionais na área de desenvolvimento, predominantemente do sexo masculino ou o que é mais gritante ainda é a necessidade de se disfarçar com avatares masculinos para não sofrerem algum tipo de abuso ou assédio.

Além disso, mostrou-se bastante discrepante o número de referências de pesquisas em tecnologia entre pesquisadores homens e mulheres, sendo o primeiro grupo muito maior. Destaco assim, portanto, os trabalhos das pesquisadoras como representatividade nesse contexto e em como mulheres pesquisadoras foram uma 
inspiração para poder continuar. Entendendo assim como é um privilégio poder ter acesso ao conhecimento, compartilhar e dialogar com tantos conceitos e teorias que alimentam a episteme.

Ao finalizar essa etapa, entendemos que uma pesquisa que estuda os desenvolvimentos tecnológicos e suas mediações nunca se encerra. Ou seja, o encerramento aqui se deu pela necessidade de conclusão burocrática.

De acordo com Latour, a cartografia se produz a partir das associações entre os atores e acaba sendo sempre provisória e é papel do pesquisador estar atento para se adentrar em fenômenos ainda em construção.

Retomamos aqui a metáfora de se estar dentro do vórtice do furacão, assim como fazia o artista Francis Alÿs que perseguia os tornados no México, e como se pensar dentro da caixa preta é um constante risco de desatualização, haja vista tamanha velocidade de alteração e desenvolvimento.

No entanto, é um risco válido e bastante animador que coloca o pesquisador em constante questionamento e incentiva a necessidade de sempre se atualizar concebendo uma visão mais integrada dos atores humanos e não humanos.

Ao mapear tendências, pode ser que daqui dez ou vinte anos esse trabalho esteja completamente ultrapassado. No entanto, há também uma possibilidade que muitas dessas perspectivas, por mais assustadoras que sejam, estejam completamente adequadas e inseridas do nosso cotidiano do futuro, dentro desses muitos futuros possíveis.

Nosso percurso foi de procurar constantemente a luz da contemporaneidade, de estar dentro do tornado, de saber ver a obscuridade e, tal como disse Agamben, buscar escrever mergulhando a pena nas trevas do presente. 


\section{REFERÊNCIAS BIBLIOGRÁFICAS}

ABRANCHES, Sérgio. A era do Imprevisto: a grande transição do século XXI, $1^{\text {a }}$ ed. São Paulo: Companhia das letras, 2017.

AGAMBEN, Giorgio. O que é o contemporâneo? E outros ensaios. Tradutor Vinícius Nicastro Honesko. Chapecó, SC: Argos, 2009.

ALTINPULLUK, Hakan. Current trends in augmented reality and forecasts about the future. $2017 . \quad$ Disponível em: <https://www.researchgate.net/publication/321762312_CURRENT_TRENDS_IN_ AUGMENTED_REALITY_AND_FORECASTS_ABOUT_THE_FUTURE>. Acesso em: 12 de fev. de 2020.

Aplicativo Drawalong AR Disponível em: $<$ https://www.youtube.com/watch?time_continue $=88 \& v=S 9 g 1 P q Y 19 j E \&$ feature $=$ emb_ title>. Acesso em: 12 de abr. de 2020.

Aplicativo Norman AR. Disponível em: $<$ https://www.youtube.com/watch?time_continue $=13 \& v=6 x T$ GrRaL66U\&feature $=e m b$ _title>. Acesso em: 12 de abr. de 2020.

ARCore Overview. Disponível em: <https://developers.google.com/ar/discover>. Acesso em: 12 de abr. de 2020.

ARELLANO, Miguel Ángel Márdero (et al). Guia de fontes de informação para editores de periódicos científicos. Brasília: Dreams Gráfica e Editora, 2007.

ARTE QUE ACONTECE. Nam June Paik: The Future is Now. 16/10/2019. Arte que Acontece. Disponível em: <https://www.artequeacontece.com.br/nam-june-paik-thefuture-is-now/>. Acesso em: 15 de mai. de 2020.

ASCOTT, Roy. TELEMATIC EMBRACE: visionary theories of art, technology, and consciousness. Edited and with an essay by Edward a. Shanken. 2003. Disponível em: <https://zaklynsky.files.wordpress.com/2013/10/telematic-embrace-visionary-theoriesof-art-technology-and-consciousness-by-roy-ascott.pdf>. Acesso em: 05 de nov. de 2018. 
ASSOCIATION OF RESEARCH LIBRARIES. Research Library Issues 298 2019: The Data Science Revolution RLI 298 (2019) Disponível em: <https://doi.org/10.29242/rli.298>. Acesso em: 18 de fev. de 2020.

AZUMA, Ronald. A Survey of Augmented Reality . In: Presence: Teleoperators and Virtual Environments 6, 4. 1997. P. 355-385. Disponível em: <https://www.ronaldazuma.com/papers/ARpresence.pdf>. Acesso em: 05 de nov. de 2018.

BARBOSA, Wilmar do Volle. In: A condição pós-moderna. Tradução: Ricardo 12a ed. Corrêa Barbosa; posfácio: Silviano Santiago - 12a ed.- Rio de Janeiro: José Olympio, 2009.

BARRY, A.,THOMAS, G., DEBENHAM, P., TROUT, J Augmented reality in a public space: the natural history museum. London, 2012. P. 42-47. Disponível em: <https://dx.doi.org/10.1109/MC.2012.106>. Acesso em 30 de set. de 2018.

BASBAUM, Sérgio Roclaw. Do ponto de vista ao ponto de experiência. (2005). Disponível em: https://www.academia.edu/3839220/Basbaum_Do_ponto_de_vista_ao_ponto_de_exper iencia >. Acesso em: 12 de mai. de 2020.

BAUM'S. L. Frank. The Master key - na electrical fairy tale (1901) Disponível em: $<$ https://archive.org/details/masterkeyanelec00corygoog/page/n210>. Acesso em: 05 de nov. de 2018.

BECKER, Howard S. Observação social e estudos de caso sociais. In: Métodos de pesquisa em Ciências Sociais. São Paulo: Hucitec, 1999.

BENJAMIN, Walter. Passagens. Organização da edição brasileira: Willi Bolle, colaboração na edição brasileira Olgária Matos. Tradução do alemão Irene Aron. Tradução do francês Cleonice Paes Barreto. Belo Horizonte: Editora UFMG; São Paulo: Imprensa Oficial do Estado de São Paulo, 2006.

Magia e técnica, arte e política: ensaios sobre literatura e história da cultura. São Paulo: Brasiliense, 2008. 
O conceito de crítica de arte no romantismo alemão. São Paulo: Iluminuras, 2011.

BERARDI, Franco. Depois do futuro. São Paulo: Ubu Editora, 2019.

BONDÍA, Jorge Larrosa. Notas sobre a experiência e o saber de experiência. Conferência proferida no I Seminário Internacional de Educação de Campinas, traduzida e publicada, em julho de 2001, por Leituras SME; Textos-subsídios ao trabalho pedagógico das unidades da Rede Municipal de Educação de Campinas/FUMEC. In: Revista Brasileira de Educação Jan/Fev/Mar/Abr2002N 19. Disponível em <http://www.scielo.br/pdf/rbedu/n19/n19a02.pdf >. Acesso em: 12 de dez. de 2018.

BOSTROM, Nick. A history of transhumanist thought. Journal of evolution and technology 14.1, 2005.

Superinteligência: Caminhos, Perigos, Estratégias. Rio de Janeiro: Darkside Books, 2018.

Scientificizing McLuhan: predicates of man-machine coupling, the triplex isomorphism hypothesis, and its aesthetic consequences. In: ARS v. 17 n. 35 Dossiê Membranas: intersecções entre arte, ciência e tecnologia: 2019.

BOURRIAUD, Nicolas. Pós-produção: como a arte reprograma o mundo contemporâneo. Tradução Denise Bottmann. São Paulo: Martins, 2009.

BOWER, M., HOWE, C., MCCREDIE, N., ROBINSON, A., Grover, D (2013). Augmented reality in education: cases, places, and potentials. IEEE 63rd Annual Conference International Council for Education Media (ICEM). 2013. Disponível em: < https://dx.doi.org/10.1109/CICEM.2013.6820176>. Acesso em: 12 de nov. de 2018.

BOWER, M., LEE, Mark J.W. DALGARNO, Barney. Collaborative learning across physical and virtual worlds: Factors supporting and constraining learners in a blended reality environment. In: British Journal of Educational Technology. 2017. Disponível em: < https://doi.org/10.1111/bjet.12435>. Acesso em: 30 de nov. de 2018. 
BRAGA, José Luiz. Para começar um projeto de pesquisa. In: Revista Comunicação e Educação, n. 3, São Paulo, dez./set. 2005.

Buff, T. (2016). Peek-a-boo, Pikachu: how the augmented reality of Pokémon Go could transform learning. Disponível em: <https://www.agylia.com/blog/mobile/howthe-augmented-reality-of-pokemon-go-could-transform-learning>. Acesso em: 20 de dez. de 2020.

Butcher, A. Pokémon Go See the World in Its Splendor. New York Times. 14/07/2016. Disponível em: <http://www.nytimes.com/2016/07/17/opinion/sunday/pokemon-gosee-the-world-in-

itssplendor.html action=click\&contentCollection=Asia\%20Pacific \&module $=$ RelatedCo verage\&region=Marginalia\&pg type=article\&_r=2>. Acesso em: 20 de dez. de 2020.

CACCHIONE, LEGG, PETERSEN. \#GOTTACATCHEMALL: exploring pokemon go in search of learning enhancement objects. 13th International Conference Mobile Learning 2017. Disponível em: <https://files.eric.ed.gov/fulltext/ED579208.pdf>. Acesso em: 20 de dez. de 2020.

CADAVIECO, Javier Fombona, GOULÃO, Maria de Fátima, TAMARGO, Marco Antonio Garcia. Melhorar a atratividade da informação através do uso da realidade aumentada. In: Perspectivas em ciência da informação. V.19, n.1, p.37-50, jan/mar 2014.

Disponível em: <http://portaldeperiodicos.eci.ufmg.br/index.php/pci/article/view/1661>. Acesso em 25 de jan. de 2020.

CASTELLS, Manuel. A sociedade em rede - a era da informação: economia, sociedade e cultura. São Paulo: Editora Paz e Terra, 2012.

CETIC - Centro Regional de Estudos para o Desenvolvimento da Sociedade da Informação. Pesquisa sobre o uso das tecnologias de informação e comunicação nos domicílios - TIC Domicílios $2017 . \quad$ Disponível em: <https://www.cetic.br/tics/domicilios/2017/domicilios/A4/ >. Acesso em: jan. de 2019.

CETIC - Centro Regional de Estudos para o Desenvolvimento da Sociedade da Informação. Pesquisa sobre o uso das tecnologias de informação e comunicação na 
Educação CGI.br/NIC.br - TIC Educação - 2019. Disponível em: <https://cetic.br/pt/pesquisa/educacao/indicadores/>. Acesso em: 20 de jan. de 2020.

CETIC - Centro Regional de Estudos para o Desenvolvimento da Sociedade da Informação. Pesquisa sobre o uso das tecnologias de informação e comunicação nos domicílios CGI.br/NIC.br - TIC Domicílio - 2019. Disponível em: $<$ https://cetic.br/media/analises/tic_domicilios_2019_coletiva_imprensa.pdf >. Acesso em: 28 de jan. de 2020 .

CHAPPLE, Craig. Pokémon GO Has Best Year Ever in 2019, Catching Nearly $\$ 900$ Million in Player Spending 09/01/2020. Sensor Tower. Disponível em: <https://sensortower.com/blog/pokemon-go-has-best-year-ever-in-2019-catchingnearly-900m-usd-in-player-spending>. Acesso em: 18 de mai. de 2020.

CHOW, Wilson; EEDEN, Ennèl Van. The Global Entertainment \& Media Outlook 2018- 2022. Disponível em: <https://www.pwc.com/gx/en/entertainmentmedia/outlook/perspectives-from-the-global-entertainment-and-media-outlook-20182022.pdf >. Acesso em: 12 de fev. de 2020.

CRAWFORD, Chris. Interview In: ROUSE, Richard. Game design: theory \& practice. By Richard Rouse III; illustrations by Steve Ogden. 2nd ed. Wordware Publishing, Inc., 2005.

CHU, Jennifer. Engineers mix and match materials to make new stretchy electronics. News MIT, 2020. Disponível em: http://news.mit.edu/2020/flexibleelectronics-stacks-chips-0205. Acesso em 15 de mai. de 2020.

CHYI, Natalie. The Coronavirus Is Democratizing Knowledge. Wired. 05.27.2020. Disponível em: <https://www.wired.com/story/opinion-the-coronavirus-isdemocratizing-knowledge/>. Acesso em: 15 de mai. de 2020.

Clancey, W. J. (1995). A tutorial on situated learning. Paper presented at the International Conference on Computers and Education, Taiwan. Disponível em: <http://konstruktivismus.unikoeln.de/didaktik/situierteslernen/clancey_situated_learnin g.PDF>. Acesso em: 20 de dez. de 2020. 
CRAIG, A.B. Understanding Augmented Reality: Concepts and Applications. Morgan Kaufmann, 2013.

CRARY, Jonathan. In: FOSTER, Hal. Vision and visuality. Dia Art foundation, 1988.

Suspensões da Percepção: atenção, espetáculo e cultura moderna. São Paulo: Cosac Naify, 2013.

24 /7: Capitalismo Tardio e os fins do sono. São Paulo: Ubu Editora, 2016.

DANTO, Arthur C. A transfiguração do lugar-comum: uma filosofia da arte. São Paulo: Cosac Naify, 2010.

DEBORD, Guy. A sociedade do espetáculo. Rio de Janeiro: Contraponto, 1997.

Definição de Tiktok. Disponível em: <https://apps.apple.com/us/app/tiktok-make-yourday/id835599320>. Acesso em: 12 de mai. de 2020.

DICKSON, Grace. Mural Arts Philadelphia debuts its first augmented reality mural, 'Dreams, Diaspora, and Destiny'. The Philadelphia Inquire. Things to do. 10 de outubro de 2018.2 Disponível em: <https://www.inquirer.com/philly/blogs/things_to_do/mural-arts-philadelphiaaugmented-reality-mural-king-britt-20181010.html>. Acesso em: 05 de nov. de 2019.

Diretrizes para apresentação de dissertações e teses da USP. Parte I (ABNT). Disponível em: $<$ http://www.teses.usp.br/index.php?option=com_content $\&$ view=article\&id=52\&Itemid $=67 \&$ lang $=$ pt - br $>$. Acesso em: 20 de mai. de 2018 .

DONATI, L.P. Computador Vestível: Experiment(AÇÃO) Tecnológica Mediada. Disponível em: <http://www.gutorequena.com.br/artigos_amigos/_luisa.htm>. Acesso em: 15 de abr. de 2020.

DUMÉ, Isabelle. Transparent graphene could advance non-silicon electronics. Physics World. 10/10/2018. Disponível em: <https://physicsworld.com/a/transparentgraphene-could-advance-non-silicon-electronics/>. Acesso em: 15 de mai. de 2020. 
ECO, Umberto. Obra aberta: forma e indeterminação nas poéticas contemporâneas. São Paulo: Perspectiva, 2010.

EURO NEWS. A queda do Muro de Berlim em realidade aumentada. Euronews. 07/11/2014. Euro News. Disponível em: <https://pt.euronews.com/2014/11/07/a-quedado-muro-de-berlim-em-realidade-aumentada>. Acesso em 07 de mar. de 2019.

FAHEY, James. James Fahey. Disponível em: <http://www.jamesfahey.com/>. Acesso em 05 de nov. de 2019.

FEIXA, Carles. LECCARDI, Carmem. O conceito de geração nas teorias sobre juventude. In: Revista Sociedade e Estado - Volume 25, Número 2. Agosto de 2010. Disponível em: < http://www.scielo.br/pdf/se/v25n2/03.pdf >. Acesso em: 7 de mar. de 2019.

FILE São Paulo 2018. Festival Internacional de Linguagem Eletrônica: o corpo é a mensagem. Organizadores Paula Perissinotto, Ricardo Barreto. Tradução e revisão/translation and proofreading Isabel Rimmer, Stephen Rimmer. São Paulo: FILE, 2018.

FILE São Paulo 2019: Festival Internacional de Linguagem Eletrônica: 20 anos de FILE 20 anos de Arte e Tecnologia./ Concepção e organização Paula Perissinotto e Ricardo Barret. Tradução e revisão Stephen Rimmer, Isabel Rimmer, Marina Jerusalinsky.1. ed. São Paulo: FILE, 2019.

FLORES, Adám Jacinto. HERRERA, Maritza Álvarez. Pokémon Go y sus factores de éxito: diseño de un modelo teórico. 2019. Disponível em: <http://www.scielo.org.co/pdf/eg/v35n152/0123-5923-eg-35-152-321.pdf>. Acesso em: 20 de dez. de 2020.

FLORIDI, Luciano. The information Society and it's Philosophy. 2009. Disponível em:

<https://www.academia.edu/14339040/The_Information_Society_and_Its_Philosophy >. Acesso em: 18 de mar. de 2019. 
Technology in Betweeness. 2013. Disponível em:

<https://www.academia.edu/14389444/Technology_s_In-Betweeness>. Acesso em 18 de março de 2019.

. What is data ethics? 2016. Disponível em: <https://royalsocietypublishing.org/doi/10.1098/rsta.2016.0360>. Acesso em 18 de março de 2019.

. Infraethics on the conditions of possibility of Morality? S pringer

Science+Business Media $\quad$ B.V. 2017 Disponível em: $<$ https://www.academia.edu/35000396/Infraethics_-

_On_the_Conditions_of_Possibility_of_Morality?email_work_card=view-paper> Acesso em: 07 de jan. de 2020.

The Fourth Revolution - How the infosphere is reshaping human reality. London: Oxford University Press, 2014.

The onlife Manifesto - Being human in a hyperconnected Era. Londres, Springer Open: 2015.

FLUSSER, Vilém. Filosofia da caixa preta. São Paulo: Editora Hucitec, 1985.

FOGLIATO, Flavia. In: FILE São Paulo 2018: Festival Internacional de Linguagem Eletrônica : o corpo é a mensagem. Organizadores Paula Perissinotto, Ricardo Barreto. Ttradução e revisão Isabel Rimmer, Stephen Rimmer. São Paulo: FILE, 2018.

FORTIM, I.; MONTEIRO, L. F. ; SANCASSANI, V. ; BENGEL, M. J. A Tipologia das Jogadoras: Um estudo do público feminino gamer brasileiro. In: SbGames 2016: XV Simpósio de Games e Entretenimento Digital, São Paulo, 2016. Disponível em: <http://www.sbgames.org/sbgames2016/downloads/anais/157458.pdf>. Acesso em: 12 de mai. de 2020.

GALVÃO, Maria Cristiane Barbosa; CARMONA, Fabio; RICARTE, Ivan Luiz Marques. A realidade aumentada e a disseminação da informação para crianças e adolescentes: estudo misto convergente. In: Brazilian Journal of Information Studies: Research Trends. 12:3,2018. p.111-p.119ISSN1981-1640. Disponível em: 
<http://www2.marilia.unesp.br/revistas/index.php/bjis/article/view/7955/5334>. Acesso em: 20 de mai. de 2019.

GEE, James Paul. Learning by Design: Good Video Games as Learning Machines. Sage Journals, 2005. Disponível em: <https://journals.sagepub.com/doi/abs/10.2304/elea.2005.2.1.5>. Acesso em: 07 de jan. de 2020.

GERALDO, Luis Gustavo Bueno. In: Soft Borders Conference \& Festival Proceedings: papers. Organização Martha Gabriel e Milton Sogabe. São Paulo: Centro Universitário Belas Artes de São Paulo, 2010.

GERRIG, R. J., ZIMBARDO, P. G., CAMPBEll, A. J., CUMMING, S. R., \& WILKES, F. J. Psychology and life. Australia: Pearson Higher Education, 2010.

GILSTER, Paul. Digital Literacy. São Francisco: John Willey \& Sons, 1997.

GOLINKOFF; HIRSH-PASEK. First Singaporean to catch all 145 Pokemon admits getting help from overseas friends. The Star Online. 19/08/2016. Disponível em: $<$ http://www.thestar.com.my/news/regional/2016/08/19/first-singaporean-to-catch-all145- pokemon-admits-getting-help-from-overseas-friends/>. Acesso em: 20 de jan. de 2020.

GOLINKOFF; HIRSH-PASEK. Pokémon Go: A window into how we might reimagine learning \#BecomingBrilliant. Disponível em: <https://www.brookings.edu/blog/education-plusdevelopment/2016/07/19/pokemon-goa-window-into-how-we-might-reimagine-learning-becomingbrilliant/>. Acesso em: 20 de dez. de 2019.

GOMIDE, João Victor Boechat In: GOBIRA, Pablo. MUCELLI, Tadeus (organizadores). Configurações do pós-digital: Arte e cultura tecnológicas. Belo Horizonte: EdUEMG, 2017.

GONÇALVES, Marly de Menezes. In: Soft Borders Conference \& Festival Proceedings. Organização; Martha Gabriel e Milton Sogabe. São Paulo: Centro Universitário Belas Artes de São Paulo, 2010. 
GOODE, Lauren. Google Lens, Augmented Reality, and the Future of Learning. 08.20.2019 Disponível em: <https://www.wired.com/story/google-lens-augmentedreality-future-of-learning/>. Acesso em: 09 de mai. de 2020.

GOOGLE. Google Glass. Disponível em: <https://www.google.com/glass/start/> Acesso em 15 de maio de 2020.

HAN, Byung-Chul. No enxame: perspectivas do digital. Tradução de Lucas Machado. - Petrópolis, RJ: Vozes, 2018.

HARAWAY, Donna. In: Reading digital culture - Edited by David Trend. Masschusetts: Blackwell Publishers, 2001.

HARDY, Michael. Meet the Transhumanists Turning Themselves Into Cyborgs (2018). Disponível em: <https://www.wired.com/story/transhumanism-cyborg-photogallery/>. Acesso em: 12 de dez. de 2019.

Hartmann, M.. Technologies and Utopias: The Cyberflaneur and the Experience of ‘being Online'. Munich: Verlag Reinhard Fischer, 2004.

HORAN, B., GARDNER, M. \& SCOTT, J. 2009. MiRTLE: a mixed reality teaching \& learning environment (Technical report no. SMLI TR-2009-182). Menlo Park, CA: Sun Microsystems. EDUCAUSE Review, vol. 43, no. 5 (September/October 2008). Disponível em: <https://er.educause.edu/articles/2008/9/mirtle>. Acesso em: 12 de dez. de 2019.

HUMANITY PLUS. Transhumanist declaration (1998, 2009) Disponível em: $<$ https://humanityplus.org/philosophy/transhumanist-declaration/>. Acesso em: $20 \mathrm{de}$ dez. de 2020.

ITO, Joi. The Responsibility of Immortality: Welcome to the New Transhumanism (2018). Disponível em: <https://www.wired.com/story/the-responsibility-ofimmortality/> Acesso em: 10 de dez. de 2019.

JACKSON, Timothy Allen. In: Reading digital culture - Edited by David Trend. Masschusetts: Blackwell Publishers, 2001. 
JEEHWAN KIM RESEARCH GROUP. News. MIT. Disponível em: <http://jeehwanlab.mit.edu/news-3/>. Acesso em: 15 de mai. de 2020.

JEEHWAN KIM RESEARCH GROUP. Peer-reviewed journals. MIT. Disponível em: <http://jeehwanlab.mit.edu/publications/>. Acesso em: 20 de abr. de 2020.

JOHNSON, Sylvester A. Technology Innovation and AI Ethics. In: Research Library Issues, no. 299 (2019): Ethics of Artificial Intelligence. 2019. Disponível em: <https://doi.org/10.29242/rli.299>. Acesso em: 18 de fev. de 2020.

KELLY, K. Out of control: the rise of neo-biological civilization. New York: Basic Books, 1994.

KELLY, Kevin. AR Will Spark the Next Big Tech Platform-Call It Mirrorworld. Wired. Business. 02.12.2019. Disponível em: <https://www.wired.com/story/mirrorworld-ar-next-big-tech-platform/>. Acesso em: 15 de mai. de 2020.

KERCKHOVE, Derrick de. A pele da cultura. São Paulo: Annablume, 2009.

KIRNER, Claudio. Realidade virtual e aumentada. [traduzido de KIRNER, C.; KIRNER, T.G. (2008)]. Disponível em: <http://www.realidadevirtual.com.br/cmsimplerv/?DEFINI\%C7\%D5ES>. Acesso em: 13 de jan. de 2019.

LACOUR, Kayla. Women Engineers On the Rampant Sexism of Silicon Valley. Wired. 06.07.17 Disponível em: <https://www.wired.com/2017/06/women-engineersrampant-sexism-silicon-valley/>. Acesso em 15 de mai. de 2020.

LANIER, Jaron. Gadget: você não é um aplicativo! TTradução Cristina Yamagami. São Paulo: Saraiva, 2010.

. Dez argumentos para você deletar suas redes sociais. Rio de Janeiro: Editora Intrínseca, 2018.

LATOUR, Bruno. Jamais fomos modernos. Rio de Janeiro: 34, 1994b.

Ciência em ação: como seguir cientistas e engenheiros sociedade afora; tradução de Ivone C. Benedetti. São Paulo: Editora Unesp, 2000. 
Reagregando o Social: uma introdução à Teoria do Ator-Rede. Salvador:

Edufba, 2012.

LAURENTIZ, Silvia Regina Ferreira de. Realidades Mistas: da Realidade Tangível à Realidade Ontológica. 2010. Disponível em:

<http://www.anpap.org.br/anais/2010/pdf/cpa/silvia_regina_ferreira_de_laurentiz.pdf $>$. Acesso em: 12 de dez. de 2019.

LAURENTIZ, Silvia. Notas sobre um pensamento conformado. In: Encontro da Associação Nacional de Pesquisadores em Artes Plásticas, 26o, 2017, Campinas. Anais do 26o Encontro da Anpap. Campinas: Pontifícia Universidade Católica de Campinas, 2017.

LE BRETON, David. A sociologia do corpo. Tradução de Sonia Fuhrmann. 6a . Rio de Janeiro: Ed. Petropolis, RJ: Vozes, 2019.

LEMOS, A. Realidad aumentada: narrativa y médios de georreferencia. Versão em português do artigo. In: Sánchez, Amaranta (org). Móbile. Reflexión y experimentatión en torno a los médios locativos en el arte contemporâneo en México. Consejo Nacional para La Cultura y las Artes/ Centro Multimedia. CENART, México, DF, 2013., ISBN - 978-607- 516-022-1, pp. 85-103. Disponível em: <file://C:/Users/belin/Downloads/Realidade_Aumentada._Narrativa_e_midias.pdf >. Acesso em: 23 de mar. de 2020.

LEMOS, André. In: Fragoso, S., et alli., Comunicação na Cibercultura. São Leopoldo: EditoraUnisinos, 2001. Disponível em: <https://www.academia.edu/1771460/CIBER-FL\%C3\%82NERIE1>. Acesso em 23 de mar. de 2020.

LI, Fei-Fei; ZHU,Yuke, GORDON, Daniel, KOLVE, Eric, FOX, Dieter, GUPTA, Abhinav, MOTTAGHI, Roozbeh, FARHADI, Ali. Visual Semantic Planning using Deep Successor Representations (2017) Disponível em: <http://vision.stanford.edu/pdf/zhu2017iccv.pdf〉. Acesso em: 12 de fev. de 2020. 
LI, Fei-Fei; KRISHNA, Ranjay; CHAMI, Ines; BERNSTEIN, Michael Bernstein; Referring Relationships (2018). Disponível em: <https://arxiv.org/pdf/1803.10362.pdf>. Acesso em: 12 de mar. de 2020.

LIPOVETSKY, Gilles. SERROY, Jean. A Estetização do Mundo: viver na era do capitalismo artista. São Paulo: Companhia das Letras, 2013.

Lopes PMA, Melo MFAQ. O uso das tecnologias digitais em educação: seguindo um fenômeno em construção. Psicol Educ [Internet]. 2014; 38(1):49-61. Disponível em: $<$ http://pepsic.bvsalud.org/scielo.php?script=sci_arttext\&pid=S14146975201400010000 $5 \& \operatorname{lng}=$ pt\&nrm=iso $>$. Acesso em 20 de fev. de 2019.

LYOTARD, Jean-François. A condição pós-moderna. Tradução: Ricardo 12a ed. Corrêa Barbosa; posfácio: Silviano Santiago. Rio de Janeiro: José Olympio, 2009.

MACHADO, Arlindo. Arte e mídia. Rio de Janeiro: Jorge Zahar Ed, 2010.

In: Arte telemática: dos intercâmbios pontuais aos ambientes virtuais multiusuário. Apresentação Arlindo Machado, Julio Plaza. São Paulo: Itaú Cultural, 2003.

MALYSSE, Stéphane Rémy. Além do corpo: a carne como ficção científica. 2000. Disponível em: <https://www.scielo.br/pdf/ra/v43n2/v43n2a16>. Acesso em: mai. de 2020.

MANOVICH. The poetics pf augmented space. 2002. Disponível em: $<$ http://manovich.net/content/04-projects/035-the-poetics-of-augmentedspace/31_article_2002.pdf>. Acesso em: 05 de mai. de 2019.

- What comes after remix. 2007. Disponível em: <http://manovich.net/content/04-projects/057-what-comes-afterremix/54_article_2007.pdf >. Acesso em: 02 de dez. de 2018.

Automating Aesthetics: Artificial Intelligence and Image Culture. Disponível em: <http://manovich.net/content/04-projects/101-automating-aesthetics- 
artificial-intelligence-and-image-culture/automating_aesthetics.pdf >. Acesso em: 21 de out. de 2018.

Designing and Living Instagram Photography: Themes, Feeds, Sequences,

Branding, Faces, Bodies. Novembro/2016. Disponível em: $<\mathrm{http}: / /$ manovich.net/content/04-projects/097-designing-and-living-instagramphotography/instagram_book_part_4.pdf>. Acesso em: 12 jan. de 2019.

Visual Semiotics, Media Theory, and Cultural Analytics. Disponível em: $<\mathrm{http}: / /$ manovich.net/content/04-projects/103-visual semiotics/manovich_visual_semiotics.pdf > Acesso em 20 de outubro de 2018.

AI Aesthetics. 2018. Disponível em: <http://manovich.net/index.php/projects/ai-aesthetics>. Acesso em: 12 de fev. de 2020. MARKLEY, Robert. In: Reading digital culture - Edited by David Trend. Masschusetts: Blackwell Publishers, 2001.

MARX, Karl. Prefácio à "Contribuição à Crítica da Economia Política". Londres: [s.n], 1859.

MCLUHAN, Marshall. The gutenberg galaxy: The Making of Typographic Man. Toronto: University of Toronto Press, 1962.

Os meios de comunicação como extensões do homem. São Paulo: Cultrix, 1964.

In: MCLUHAN, Eric \& ZINGRONE, Frank. Essential Mcluhan. Toronto: Anansi, 1995.

FIORE, Quentin; AGEL, Jerome. O meio é a massagem. São Paulo: Ubu Editora, 2018.

MICROSOFT. Hololens. Disponível em: 〈https://www.microsoft.com/en-us/hololens〉. Acesso em: 15 de mai. de 2020.

MIGALA, Jessica. 'Snapchat Dysmorphia': Is the Stress of Social Media Driving Teens to Plastic Surgery? 16/10/2018. Disponível em: 
<https://www.everydayhealth.com/wellness/united-states-of-stress/what-snapchatdysmorphia-detailed-look-trend/>. Acesso em: 20 de dez. de 2019.

MILGRAM, Paul; TAKEMURA, H., UTSUMI A., KISHINO, F. Augmented Reality: A class of displays on the reality-virtuality continuum. Proceedings of Telemanipulator and Telepresence Technologies. 1994. Disponível em: <https://www.researchgate.net/publication/228537162_Augmented_reality_A_class_of _displays_on_the_reality-virtuality_continuum>. Acesso em: 07 de ag. de 2018.

MOJO VISION. Mojo Lens. Disponível em: 〈https://www.mojo.vision/mojo-lens> Acesso em: 15 de mai. de 2020.

MORA, Raúl A. Micro-Paper 7: Literacy. In: LSLP Micro-Papers, No. 7, 2014. Disponível em: <http://www.literaciesinl2project.org/uploads/3/8/9/7/38976989/lslpmicro-paper-7-literacy.pdf>. Acesso em: 7 de mar. de 2019.

Revisiting todays language ecologies new questions about language use and literacy. Abril/2015. Disponível em: <https://globalconversationsinliteracy.wordpress.com/past-webinars/2014-2015-gclrweb-seminar-series/dr-raul-alberto-mora-april-2015-revisiting-todays-languageecologies-new-questions-about-language-use-and-literacy-practices/>. Acesso em: $7 \mathrm{de}$ mar. de 2019.

MORIN, Edgar. Ciência com consciência. Rio de janeiro: Bertrand Brasil, 2002.

Introdução ao pensamento complexo. Porto Alegre: Sulina, 2011.

MOROZOV, Evgeny. Big Tech: a ascensão dos dados e a morte da política. São Paulo: Ubu Editora, 2018.

MOTTA, Alda Britto da. WELLER, Wiwian. Apresentação: a atualidade do conceito de gerações na pesquisa sociológica. In: Revista Sociedade e Estado - Volume 25, Número 2. Agosto de 2010. Disponível em: < http://www.scielo.br/pdf/se/v25n2/02.pdf >. Acesso em: 7 de mar. de 2019. 
NEWZOO. Newzoo Global Games Market Revenues 2018. Disponível em: $<$ https://newzoo.com/insights/trend-reports/newzoo-global-games-market-report-2018light-version/>. Acesso em: 12 de mai. de 2020.

NEWZOO. Newzoo Global Games Market Revenues. 2019. Disponível em: <https://newzoo.com/solutions/standard/market-forecasts/global-games-marketreport/>. Acesso em: 12 de mai. de 2020.

PALAUS, Marc. MARRON, Elena. VIEJO-SOBERA, Raquel. REDOLAR-RIPOLL, Diego. Neural Basis of Video Gaming: A Systematic Review. 2017. Disponível em: <https://www.frontiersin.org/articles/10.3389/fnhum.2017.00248/full>. Acesso em: 20 de dez. de 2020.

PARDES, Arielle. For Museums, Augmented Reality Is the Next Frontier. 09.21.2018 Disponível em: https://www.wired.com/story/museums-augmented-realitynext-frontier/ Acesso em: 20/12/2020.

PARDES, Arielle. The WIRED Guide to the Internet of Things. 02.10.2020. Disponível em: <https://www.wired.com/story/wired-guide-internet-of-things/>. Acesso em: 12 de mai. de 2020.

PARENTE, André (Org.) Tramas da rede. Porto Alegre: Sulina, 2004.

PASSARELLI, Brasilina. Atores em rede: 20 anos na esteira da construção coletiva do conhecimento - Relatos de pesquisa. 2009. Disponível em $<$ https://uspbr.academia.edu/BPassarelli > Acesso em 01 de abril de 2019.

Interfaces Digitais na Educação: @lucin[ações] consentidas. São Paulo: Editora Senac, 2007.

PASSARELlI, B.; Azevedo, J. (Orgs.). Atores em rede: olhares luso-brasileiros. São Paulo: Editora Senac SP, 2010.

PASSARELLI, Brasilina; GOMES, Ana Claudia Fernandes. Transliteracias: A Terceira Onda Informacional nas Humanidades Digitais. In: RICI: R.Ibero-amer. Ci. Inf., ISSN 1983-5213, Brasília, v. 13, n. 1, p. 253-275, jan./abril 2020. Disponível em: <https://doi.org/10.26512/rici.v13.n1.2020.29527> Acesso em: 08 de jun. de 2020. 
PEIRCE, Charles Sanders. The electronic edition of The collected Papers of Charles Sanders Peirce. Utah: Folio Corporation (Vol. I-VI edited by Charles Hartshorne e Paul Weiss; vol. VII-VIII edited by Artur W. Burks), Harvard University Press, 1994.

Pesquisa Game Brasil 2018. Por Sioux Group, Blend New Research, ESPM e Go Gamers Disponível em: <https://rdstationstatic.s3.amazonaws.com/cms\%2Ffiles\%2F62186\%2F1556825231PGB_2018_Painel.p df?utm_campaign=material_2018\&utm_medium=email\&utm_source=RD+Station $>$. Acesso em: 12 de mar. de 2020.

PHINGBODHIPAKKIYA, Amanda. The neuroscience of pokémon go. 01/08/2016. Blog TED Ed. Disponível em: <https://blog.ed.ted.com/2016/08/01/the-neuroscienceof-pokemon-go/>. Acesso em 18 de mai. de 2020.

POKÉMON GO. POKÉMON GO: Advanced gym strategy. YouTube. 07/10/2017 Disponível em:

$<$ https://www.youtube.com/watch?v=0rzUDBnT4uQ\&list=PL6XC1i5bNldmMPVdSG 4. $x y d F H k I 0 N A a 4 c O \& i n d e x=3>$. Acesso em: 15 de abr. de 2020.

POKÉMON GO. POKÉMON GO: Visiting gyms. YouTube. 07/10/2017. Disponível em: $<$ https://www.youtube.com/watch?v=Z095dFUW0Q\&list=PL6XC1i5bNldmMPVdSG4xydFHkI0NAa4cO\&index=2>. Acesso em: 19 de abr. de 2020.

PONTO ELETRÔNICO. Pesquisa Geração Z: a geração da verdade - Box 1824. 2018. Disponível em: <http://pontoeletronico.me/2018/true-gen-a-geracao-daverdade/>. Acesso em: 12 de jan. de 2019.

PRADO, Gilbertto. Arte telemática: dos intercâmbios pontuais aos ambientes virtuais multiusuário. Apresentação Arlindo Machado, Julio Plaza. São Paulo: Itaú Cultural, 2003.

QUÉAU, Philippe. Le virtuel: vertus et vertiges. Paris: Champ Vallon, 1993.

RADFAHRER, Luli. Tecnologias interferem na percepção da realidade. Disponível em: <https://jornal.usp.br/atualidades/tecnologias-interferem-na-percepcao-darealidade/>. Acesso em: 15 de mai. de 2020. 
Os tatuáveis estão chegando. Disponível em: <https://jornal.usp.br/radiousp/os-tatuaveis-estao-chegando/>. Acesso em: 10 de mai. de 2020.

Ramirez, M. Emerging trends in Augmented Reality. 2014. Disponível em: <https://www.jisc.ac.uk/blog/emergingtrends-in-augmented-reality-15-jul-2014>.

Acesso em: 20 de dez. de 2020.

REMTULLA, ALY KASSAM. When Schools Reopen, Don't Ditch Online Learning (2020) Disponível em: <https://www.wired.com/story/opinion-when-schools-reopendont-ditch-online-learning/>. Acesso em: 20 de mai. de 2020.

ROCHA, Leonardo. Niantic, de Pokémon GO e Harry Potter WU, está criando óculos AR para games. Tec Mundo. 06/12/2019. Disponível em: <https://www.tecmundo.com.br/dispositivos-moveis/148373-niantic-pokemon-goharry-potter-wu-criando-oculos-ar-games.htm>. Acesso em: 15 de mai. de 2020.

RUBIN, Peter. Minecraft Earth Lands in the US-Let the Block Party Begin 11.12.2019. Disponível em: <https://www.wired.com/story/minecraft-earth-americalaunch/>. Acesso em: 12 de mai. de 2020.

RUBIN, Peter. Minecraft Earth Wants to Be the Next Pokémon Go-But Bigger. Wired. 05.17.2019 Disponível em: <https://www.wired.com/story/minecraft-earthwants-to-be-the-next-pokemon-go-but-bigger/> . Acesso em: 15 de mai. de 2020.

RUSH, Michael. Novas mídias na arte contemporânea. São Paulo: Martins Fontes, 2006.

RUSH, Michael. New Media in Art. New York: Thames \& Hudson, 2005.

SAKUDA, Luiz Ojima; FORTIM, Ivelise (Orgs.). II Censo da Indústria Brasileira de Jogos Digitais. Ministério da Cultura: Brasília, 2018. Disponível em: <http://www.tinyurl.com/censojogosdigitais>. Acesso em: 12 de fev. de 2020.

SANTAELLA, Lucia. As ambivalências das mídias móveis e locativas. In: BEIGUELMAN, Giselle; LA FERLA, Jorge (orgs). Nomadismos tecnológicos. São Paulo: Senac, 2011. 
SENSOR TOWER. Pokémon Home Was Downloaded 1.3 Million Times in Its First

Week on Mobile - FEB 20, 2020. Sense Tower Disponível em: <https://sensortower.com/blog/pokemon-home-first-week-downloads-revenue>.

Acesso em: 12 de mai. de 2020.

SEYMOUR, Sabine. Fashionable Technology The Intersection of Design, Fashion, Science, and Technology. Springer-Verlag/WienPrinted, Austria: 2008.

SHANE, Janelle. That Bot Is a Human! How to tell when a person is pretending to be an A.I. 2018. Disponível em: <https://slate.com/technology/2018/09/how-to-tellwhether-a-bot-is-really-a-human.html>. Acesso em: 12 de fev. de 2020.

Le our algorithm choose your halloween costume. (2018) Disponível em: <https://www.nytimes.com/interactive/2018/10/26/opinion/halloween-spookycostumes-machine-learning-generator.html>. Acesso em: 12/ de fev. de 2020.

SILVA, Camile. Liquid Architectures: Marcos Novak's Territory of Information. Tenth International Conference on Information Visualisation. 2006. Disponível em: <https://pdfs.semanticscholar.org/0923/91c3418033a875330e6ee68d9f325cef819a.pdf> . Acesso em: 05 de nov. de 2018.

SIOUX, BLEND RESEARCH. Pesquisa Game brasil 2018. São Paulo: Sioux Group, Blend Research, ESPM, 2018. Disponível em: <https://rdstationstatic.s3.amazonaws.com/cms\%2Ffiles\%2F62186\%2F1556825231PGB_2018_Painel.p df?utm_campaign=material_2018\&utm_medium=email\&utm_source=RD+Station $>$. Acesso em: 12 de mai. de 2020.

SNDRV. Augmented Reality Art Invasion! Disponível em: <http://www.sndrv.nl/moma/>. Acesso em: 20 de abr. de 2020.

SOUSA SANTOS, Boaventura de. Introdução a uma ciência pós-moderna. Rio de Janeiro: Graal: 1989.

SOUSA, Janara \& CURVELHO, João \& RUSSI, Pedro (org.) 100 anos de McLuhan. Brasília: Casa das Musas, 2012. 
SULLIVAN. Mark. The making of Mojo, AR contact lenses that give your eyes superpowers. Fast Company. 16/01/2020. Disponível em: $<$ https://www.fastcompany.com/90441928/the-making-of-mojo-ar-contact-lenses-thatgive-your-eyes-superpowers>. Acesso em: 15 de mai. de 2020.

SUTHERLAND, I.E. The Ultimate Display. In: Proceedings of IFIPS Congress. New York City, NY, vol. 2. 1965.

A Head-mounted Three-dimensional Display. In: Fall Joint Computer Conference, AFIPS Conference Proceedings, vol. 33. 1968.

TALK DIGITAL. O Mundo Invisível dos Gamers. TalkDigital, 2017. Disponível em: $<$ http://gamers.talkdigital.co/wp-content/uploads/2017/09/O-mundo-invisivel-dosgamers.pdf >. Acesso em: 12 de mai. de 2020.

TATE MODERN. Nam June Paik: exhibition guide. Tate Modern Website. Disponível em: <https://www.tate.org.uk/whats-on/tate-modern/exhibition/nam-junepaik/exhibition-guide>. Acesso em: 15 de maio de 2020.

The AR Manifesto. Venice Biennale Intervention, 2011. We AR in MoMA, 2010 Disponível em: <http://manifest-ar.art/>. Acesso em: 20 de abr. de 2020.

THIOLLENT, Michel. Metodologia da pesquisa-ação. São Paulo: Cortez, Autores Associados, 1986.

TURKLE, Sherry. Alone Together: why we expect more from technology and less from each other. Philadelphia: Basic Books, 2011.

.In: Reading digital culture. Edited by David Trend. Masschusetts: Blackwell Publishers, 2001.

WATERCUTTER, Angela. This 8-Minute Galactic Primer Is the Future of AR Education. 08.26.2019 Disponível em: <https://www.wired.com/story/how-we-learnaugmented-reality-wonderscope/>. Acesso em: 12 de mai. de 2020.

VENTURELLI, Suzete; MELO, Marcilon Almeida de; O visível do invisível: data art e visualização de dados. In: ARS v. 17 n. 35 Dossiê Membranas: intersecções entre arte, ciência e tecnologia: 2019. 
WAGNER, Marcos. RIBEIRO, S. ZORZAL, Ezequiel Roberto (org). Realidade Virtual e Aumentada: Aplicações e Tendências. Editora SBC - Sociedade Brasileira de Computação, Uberlândia: 2011.

WATERCUTTER, Angela. This 8-Minute Galactic Primer Is the Future of AR Education. 08.26.2019 Disponível em: <https://www.wired.com/story/how-we-learnaugmented-reality-wonderscope/>. Acesso em: 12 de mai. de 2020.

WOOD, David M. Augmented reality or alternate unrealities. Disponível em: <https://ubisurv.wordpress.com/2010/01/18/augmented-reality-or-alternate-unrealities/ 2010>. Acesso em: 23 de mar. de 2020.

Yaseen, S. G., Dajani, D. y Hasan, Y. The impact of intellectual capital on the competitive advantage: Applied study in Jordanian telecommunication companies. Computers in Human Behavior, 62, 2016. P. 168-175. Disponível em: <http://dx.doi.org/10.1016/j.chb.2016.03.075>. Acesso em: 20 de dez. de 2020.

YIN, R. K. Estudo de caso: planejamento e métodos. 3. ed. Porto Alegre: Bookman, 2005 .

ZACH, F. J. y Tussyadiah, I. P. (2017). To Catch Them All-The (Un)intended Consequences of Pokémon GO on Mobility, Consumption, and Wellbeing. Information and Communication Technologies in Tourism 2017. P. 217-227. Disponível em: <http://dx.doi.org/10.1007/978-3-319-51168-9_16>. Acesso em: 20 de dez. de 2020.

ZSILA, Á., OROSZ, G., BÖTHE, B., TÓTH $\neg$ KIRÁLY, I., KIRÁLY, O., GRIFFITHS, M. y Demetrovics, Z. (2018). An empirical study on the motivations underlying augmented reality games: The case of Pokémon GO during and after Pokémon fever. Personality and Individual Differences, 133, 56-66. Disponível em: <http://dx.doi.org/10.1016/j.paid.2017.06.024>. Acesso em: 20 de dez. de 2020. 
